\title{
RE-MAPPING CENTRE AND PERIPHERY
}

Asymmetrical Encounters in European and Global Contexts

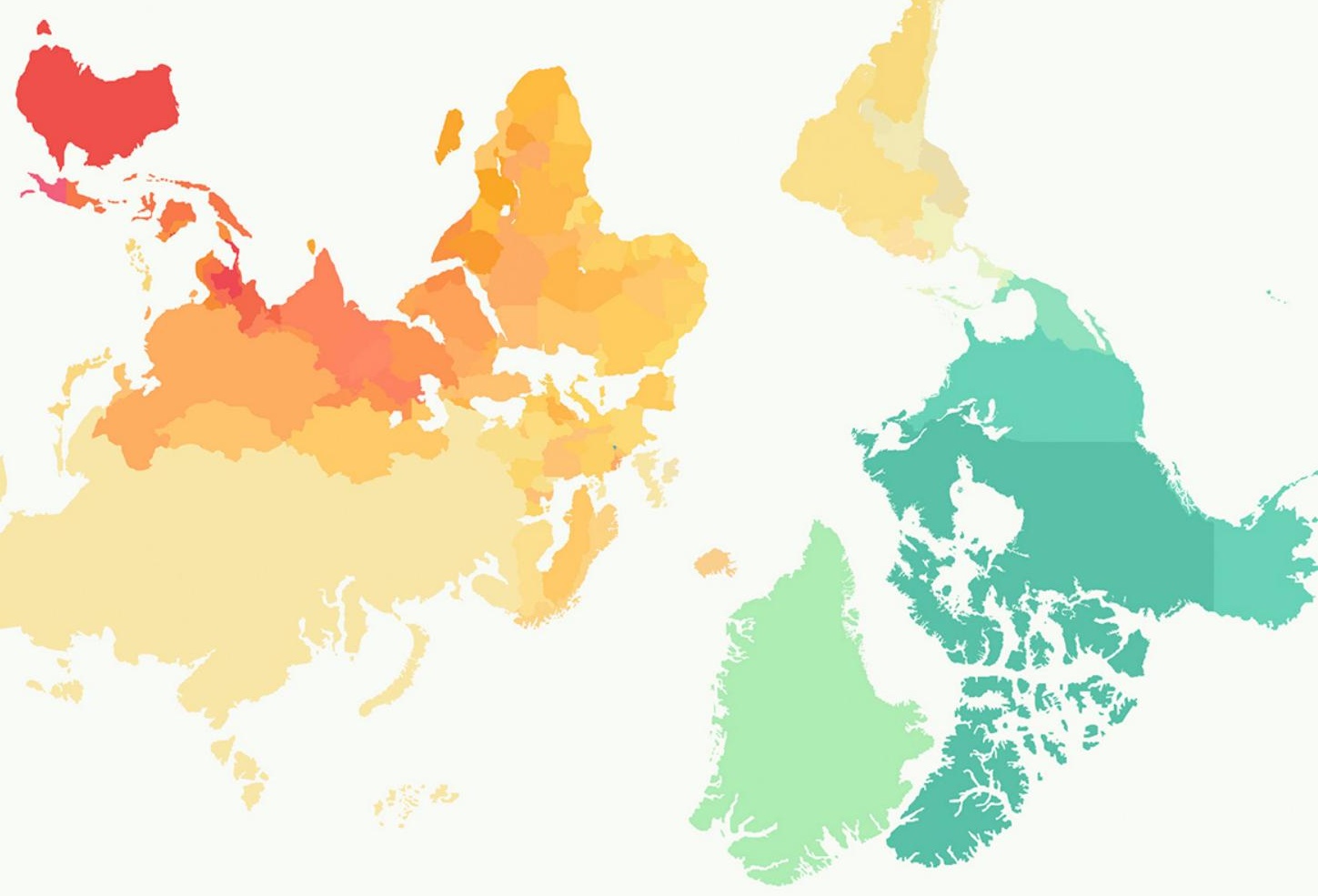

Edited by

Tessa Hauswedell, Axel Körner and Ulrich Tiedau

\section{^UCLPRESS}


Re-Mapping Centre and Periphery 



\section{Re-Mapping Centre and Periphery}

Asymmetrical Encounters in European and Global Contexts

Edited by Tessa Hauswedell, Axel Körner and Ulrich Tiedau 
First published in 2019 by

UCL Press

University College London

Gower Street

London WC1E 6BT

Available to download free: www.ucl.ac.uk/ucl-press

Text (C) Authors, 2019

Images (C) Authors and copyright holders named in captions, 2019

The authors have asserted their rights under the Copyright, Designs and Patents Act 1988 to be identified as authors of this work.

A CIP catalogue record for this book is available from The British Library.

This book is published under a Creative Commons 4.0 International licensee (CC BY 4.0). This license allows you to share, copy, distribute and transmit the work; to adapt the work and to make commercial use of the work providing attribution is made to the authors (but not in any way that suggests that they endorse you or your use of the work). Attribution should include the following information:

Hauswedell, T., Körner, A., Tiedau, U. Re-Mapping Centre and Periphery: Asymmetrical Encounters in European and Global Contexts. London: UCL Press. https://doi.org/ 10.14324/111.9781787350991

Further details about Creative Commons licenses are available at http://creativecommons.org/licenses/

ISBN: 978-1-78735-101-1 (Hbk.)

ISBN: 978-1-78735-100-4 (Pbk.)

ISBN: 978-1-78735-099-1 (PDF)

ISBN: 978-1-78735-102-8 (epub)

ISBN: 978-1-78735-103-5 (mobi)

ISBN: 978-1-78735-104-2 (html)

DOI: https://doi.org/10.14324/111.9781787350991 


\section{Contents}

1. Space and Asymmetric Difference in Historical Perspective: An Introduction

Axel Körner

Part I: Concepts

2. Rethinking Centre and Periphery in Historical Analysis:

Land-based Modernization as an Alternative Model from the Peripheries

Marta Petrusewicz

3. Europe and the Concept of Margin

Jan Ifversen

4. After Identity: Mentalities, European Asymmetries and the Digital Turn

Joris van Eijnatten

\section{Part II: Globalizing Peripheries}

5. From the Baltic to the Pacific: Trade, Shipping and Exploration on the Shores of the Russian Empire

Michael North

6. Republics of Knowledge: Interpreting the World from Latin America

Nicola Miller

7. From Manchester and Lille to the World:

Nineteenth-century Provincial Cities Conceptualize

their Place in the Global Order

Harry Stopes 
Part III: Ideas and Commodities in Motion

8. Turning Constitutional History Upside Down: The 1820s Revolutions in the Mediterranean Jens Späth

9. The Cosmopolitan Morphology of the National Discourse: Italy as a European Centre of Intellectual Modernity Alessandro de Arcangelis

10. 'The Greatest City the World has Ever Seen': London's Imperial and European Contexts in British Public Debates, 1870-1900

Tessa Hauswedell

11. Mediating Hybrids: Consumption and Transnationality Hermione Giffard

12. Re-Mapping Centre and Periphery: Concluding Thoughts Ulrich Tiedau

List of Figures

Notes on Contributors

Index 


\section{Space and Asymmetric Difference in Historical Perspective: An Introduction}

Axel Körner

In 1851 the Italian philosopher and statesman Vincenzo Gioberti, arguably Italy's most influential political thinker at the time and a former Prime Minister of Piedmont-Sardinia, self-confidently described England as 'the Sicily of Europe': an oceanic island in the continent's northern periphery, whose connection to Europe was allegedly on a par with Sicily's relationship to the Italian peninsula. ${ }^{1}$ While from an economic point of view, or within a global perspective, Gioberti's description certainly did not correspond to the ways in which the British people perceived their own position in the world, the Italian thinker used the comparison to explain Europe's political and cultural heterogeneity, including differences between institutions and constitutional developments. For the famous philosopher, there was not only one way of representing Europe's core, not only one way of being modern. ${ }^{2}$ Convinced of Italy's primacy in Europe, an argument based on the country's cultural and religious legacy as a Mediterranean civilization, Gioberti rejected the idea that Italy had to be taught lessons by seemingly more developed countries. Instead, for Gioberti, political, constitutional or economic institutions had to reflect local and historical conditions. ${ }^{3}$

While Gioberti used England's alleged marginality as a relational description to speak about the Italian states prior to their political unification, from today's perspective recent political developments seem to confirm Gioberti's assessment of Britain's position in Europe. Also today, this position depends less on objective facts than on discursive strategies, in this case on developments of Britain's own making. During the campaign leading to the referendum on Britain's membership of the European Union in June 2016, the country's position within the EU was 
instrumentalized to negotiate and contest a broad range of social, political and cultural conflicts at home, many of which were only indirectly affected by EU policies. Both examples - Gioberti's idea of Italy's primacy as well as Britain's marginality within Europe - show how discursive constructions of spatial differences between centre and periphery depend on subjective viewpoints that then serve as instruments in politics. As relational terms these differences construct selves as well as others, based on constantly shifting economic, political or cultural contexts. The semantic content of such notions is determined by transnational exchanges, where a range of different parameters is amalgamated to suit subjective discursive interests.

This book examines cultural, intellectual and economic exchanges in order to assess how these contribute to the construction of spatial hierarchies. While goods are usually exchanged in two directions, with regard to knowledge historians often assume a one-directional transmission, which is then used to establish an intellectual or political order that assigns particular spaces to positions of either core or periphery. We can identify a typical example of this approach in the field of transatlantic constitutional history, where, for instance, the global impact of the American constitution - and consequently the United States' primacy in the world is discussed without taking into consideration how republican or federal concepts that originated in European political thought related to the emergence of the United States' political institutions. ${ }^{4}$ Taking a different, more critical approach, David Armitage and Sanjay Subrahmanyam have underlined how the cultural and political experiences of many different peoples and nations have contributed to the American constitution's emancipatory potential. ${ }^{5}$ One-directional examinations of constitutional flows tend to undermine the creative force associated with the amalgamation of ideas into local knowledge and practices. At times this process of amalgamation might turn into what the semiotician Umberto Eco has called 'aberrant decoding', where interpretations share close to nothing with the original author's intentions. ${ }^{6}$

Providing an example for spatial hierarchies from another context of historical analysis, the musicologist Anselm Gerhard has demonstrated the relative insignificance of geographical and/or political criteria for notions of centre and periphery in the development of European art music. ${ }^{7}$ For the long period from the fourteenth to the first half of the nineteenth century, Italy, and Southern Italy in particular, occupied a prime position in European music, largely a consequence of its institutions of cultural representation related to the life of its numerous splendid courts. Meanwhile, a city like Prague, in the geographical centre of 
Europe, and since the Middle Ages a major imperial residence of the Luxemburgs and then the Habsburgs, created a significant international reputation as a centre of musical activity from the mid-eighteenth century only, symbolized by the original productions of two of Mozart's great late operas, Don Giovanni (1787) and La clemenza di Tito (1791). It was on the basis of this reputation that the city was subsequently able to attract young conductors and composers like Carl Maria von Weber (from 1813) and Gustav Mahler (from 1885) to lead its orchestras.

In recent decades, transnational and global history have contributed to a more inclusive understanding of intellectual and cultural exchanges, challenging the ways in which we tend to assign positions of centre and periphery on our mental maps. For instance, Christopher A. Bayly has demonstrated how India's liberal tradition helped to transform ideas received from progressive Western thinkers in order to challenge imperial relationships. ${ }^{8}$ During the nineteenth century the number of people affected by similar examples of global exchanges increased, as did the speed at which such connections were established. Meanwhile, challenges arising from globalization that subsequently impacted on existing spatial hierarchies were not a new experience in the nineteenth century. ${ }^{9}$ As Michael North has argued, during the Middle Ages, from the twelfth century onwards, new commercial connections transformed a vast space from the Mediterranean via the Arabian Sea to the Indian Ocean into a single maritime network. ${ }^{10}$ This development had dramatic consequences for the ways in which Europeans, as well as particular countries within Europe, positioned themselves within global space and historical time. Following a more specific geographical and historiographical emphasis, Akira Iriye has demonstrated how in the case of nineteenth-century Japan the wider world suddenly became 'the mental universe, in which Japanese people and their leaders have sought to understand their place and their role in the international community'. ${ }^{11}$ Based on a different epistemological approach, postcolonial theory has helped us to understand how empires constructed spatially specific hierarchies between notions of citizenship, gender, class, religion and race, in the colonial periphery as well as at home in the metropole. ${ }^{12}$ Rethinking exchanges between colonizers and colonized therefore challenged preconceived ideas about the flow of ideas and related cultural practices, emphasizing instead the hybrid nature of colonial relationships. Following their own political and economic rationale, empires also changed the world order by forming new transnational connections between themselves. ${ }^{13}$ These processes constantly defined, shifted and transformed the parameters of spatial hierarchies. 
While global and transnational history, as well as a wider bibliography that responds to the recent spatial turn in the social sciences, provide the backdrop to our book's approach to spatial hierarchies, this introductory chapter cannot offer a complete overview of those different fields of scholarship. ${ }^{14}$ Instead, a few references will serve to map out the origins of the multi-disciplinary debate on the interconnectedness of centres and peripheries, an issue further explored in the following chapter by Marta Petrusewicz. That historians have adopted a critical approach to concepts of core and periphery owes much to development debates among economists and geographers of the late 1960s and 1970s. Here Marx's theory of surplus value and Lenin's writings on imperialism presented an important starting point in trying to identify the causes of persisting global inequalities. A broad range of less ideologically driven economic theories that had emerged since the 1930s fostered empirical enquiries into those questions. For instance, Samir Amin and André Gunder Frank, based on different sets of data, analysed the relationship between advanced and less developed economies as a necessary condition for the rise of capitalism as a whole. ${ }^{15}$ Many of the concepts first discussed during those early years still remain influential in the most recent works on the geography of the world economy. ${ }^{16}$

The most influential historian to critically adopt the 'core'/"periphery' paradigm in the 1970s was Immanuel Wallerstein. At the centre of his world-system analysis was a critique of the ideological foundations of modernization theory, through emphasis on the exploitative relationship between 'advanced' economies and the allegedly less developed parts of the world. ${ }^{17}$ Wallerstein insists on the existence of a single capitalist world economy that defines the tensions between various 'national' and 'colonial' economies, and a single system of 'international' trade. The fact that particular states expanded their jurisdiction and administrative structures into foreign territories played an important part in fostering the system's internal hierarchies. Wallerstein's theoretical framework also impacted on economic studies of a smaller geographical scale, although often producing different outcomes. For instance, in her influential book Latifundium (1989), Marta Petrusewicz challenged conventional notions of centre and periphery by describing the Southern Italian economy as a rational system of production that after 1800 secured the livelihood of a society that efficiently combined feudal with capitalist elements of production. ${ }^{18}$

These debates have subsequently been reflected in the various approaches to global and transnational history, and in particular in new economic and imperial history. Here a global focus on transnational 
economic connections has helped to challenge conventional hierarchies by putting more recent world economic developments into a historically informed perspective. Kirti Chaudhuri pioneered the tracing of cultural and economic interactions in the Indian Ocean between 700 and 1750 , demonstrating that the Islamic civilization entered this system of trade several centuries before the Europeans. ${ }^{19}$ Other historians, adopting a different geographical perspective, pointed out that between the so-called Middle Ages (in itself a Eurocentric concept) and the beginning of the nineteenth century, China was the world's most powerful centre of commercial and cultural exchange. ${ }^{20}$ These very different studies have in common that they show how the rise of Europe as a global power is a relatively recent phenomenon. Contrary to many traditional accounts, written within a 'Western' or Atlantic perspective, Europe's rise does not coincide with the 'discovery' of the New World several centuries earlier. ${ }^{21}$ While it is correct that around 1900 Britain led worldwide manufacturing output, followed closely by the United States, as late as 1800 China was still producing more manufactured goods than any other country in the world, which helps to explain China's long history as a global power and its related ambition in contemporary politics. As Christopher Bayly has argued, it was between the late eighteenth and the early twentieth century that uniformities in state administration, trade and political ideologies placed the European imperial system at the centre of new transnational connections, in particular with the Islamic world and South Asia. ${ }^{22}$ These new hierarchies were reflected in concepts of race, in the economic and ecological degradation of entire world regions, and in the use of violence as a basis of defining global power. As a direct consequence of these forms of imperial exploitation, a historical lack of state structures in the world's postcolonial regions still determines the peripheral status of, for instance, large parts of Africa. According to Andreas Eckert, it was the language of Empire that described Africa as a continent without history. ${ }^{23}$

What makes our book original, and distinguishes it from this wider historiographical context, is its emphasis on the asymmetrical nature of intellectual and cultural encounters, and on examples where a traditional understanding of centre and periphery is turned upside down as a consequence of a change of focus. In three sections and eleven chapters, framed by a conceptual introduction and a summative conclusion, this book investigates the multi-directional structure of cultural and intellectual exchanges between different parts of Europe as well as within a global context. What the examples discussed in these chapters share is that they oblige us to rethink pre-established mental maps. ${ }^{24}$ While the book as a whole aims to challenge the way we use concepts like centre 
and periphery as analytical categories, its individual chapters present case studies to illustrate how the terminologies of spatial hierarchy are constructed and applied, but also how empirical facts challenge established relational terms. In our book the asymmetrical and multi-directional structure of cultural and intellectual exchanges emerges from the multitude of empirical examples covering different parts of the globe over several centuries. This approach differs from other studies in the field, which tend to concentrate on very specific themes within relatively well-defined notions of time and space. ${ }^{25}$ We hope that our book's change of scope allows us to gain a number of more abstract and conceptual insights.

In order to channel this debate in the direction of possible theoretical and methodological insights, the volume starts with a section that discusses some of the different conceptual approaches our authors have used to analyse and rethink the relationship between centre and periphery, as well as the normative value often attached to those terms. All three of those chapters take different regions within Europe, or Europe in its relationship to the world, as a starting point; but the main aim of these chapters is to familiarize readers with different theoretical and conceptional tools (as well as related methodologies) that all serve the purpose of discussing spatial hierarchies. In her opening contribution, Marta Petrusewicz provides us with a crucial historiographical background to the debates this book attempts to tackle. As already briefly outlined above, the relational nature of the terms centre (or core) and periphery was first revealed by critical development theorists in the 1960s who were keen to challenge the binary use of the terms 'developed' and 'underdeveloped'. Insights gained from the relationship between these terms were then applied to a wider range of historical contexts, initially to explain the origins and nature of the capitalist world system, and later to analyse different historical examples where spatial hierarchies played a constitutive role. Petrusewicz compares examples from four different geographical contexts in order to show that before the late nineteenth century, and preceding the consolidation of the political economy dogma, there existed not one, but several possible paths of economic development, and that no particular path was perceived to inherently define a region as core or periphery. In particular, there existed land-based models of modernization that defined themselves as alternatives to the classical economists of the Manchester School and that allow us to fundamentally rethink the ways in which we apply concepts of core and periphery.

Petrusewicz uses the term 'reference culture' to illustrate how modernizers in the periphery of the economic world system related their ideas 
to those operating at the core. Several contributors to this volume, most of them working within the field of the digital humanities, employ the concept of reference culture in order to define the relationship between smaller countries and the wider world. Joris van Eijnatten illustrates the subjective nature of such asymmetric relations. He starts by reporting how recent public debate in the United States created (positive) images of America by constructing (negative) images of Europe. In this particular case Americans discussed racism as a specific European legacy. The subjective nature of such a rhetorical device, and the ways it is used to create hierarchies between different levels of 'civilization', is easily revealed by reference to those many generations of Europeans whose idea of the United States was formed by what they knew about the United States' slave economy and its persisting consequences for race relations once the institution of slavery had been abolished. ${ }^{26}$ Following a survey of literature in critical theory and cultural studies, van Eijnatten suggests replacing the concept of identity that directly depends on alterity, with a new focus on mentalities, which he considers to be more self-referential and less dependent on the construction of an Other. According to van Eijnatten, reference cultures can be imitated, adapted and resisted, and therefore they remain more amiable than a discourse based on identities. Digital humanities allow us to examine a huge amount of information on those mentalities, and on the ways they construct what they see as central or peripheral.

In the final chapter of the introductory section, Jan Ifversen examines the construction of asymmetrical differences by taking a conceptual history approach, which he exemplifies by analysing different categories of marginality within Europe. In Ifversen's account, marginality presents itself as a conceptual alternative to the terminology of periphery. As a relational term, marginality positively reflects Europe's internal diversity, while also presenting the challenge of confronting us with a different normative category. His chapter compares different forms of marginality within modern Europe, while also introducing the term as an analytical category to identify new asymmetrical differences in a range of geographical contexts. As is the case with reference cultures, Ifversen shows how digital humanities provide a rich material basis for exploring this methodological approach.

The book's second section introduces a set of empirical case studies, while also widening our geographical and chronological scope. 'Globalizing peripheries' demonstrates how places that are usually categorized on the basis of their peripheral location challenge such hierarchies through a focus on new or different parameters. Taken together, the chapters of this section 
raise questions about the definition of spatial hierarchies as well as about the origins of global asymmetries. Based on a dense empirical survey of Russian colonial and maritime ventures, Michael North explains Russia as an empire of many heterogeneous peripheries that connected it with different parts of the globe. This scenario led to a situation where the Empire's political centre did not necessarily overlap with its core of imperial power. By connecting its outposts in the Baltic Sea with those in the Pacific, the Empire attempted to turn geographical peripheries into imperial centres. Although a Russian Pacific never materialized, such ideas deeply marked Russia's as well as Europe's spatial imagination. With Nicola Miller's chapter on republics of knowledge, we move across the Atlantic in order to gaze at the world from Latin America. Evoking a situation that shows clear similarities to the views on agricultural reform discussed in Marta Petrusewicz's chapter, Miller starts with an anecdote about the celebrated Argentine poet José Hernández refusing to accept the decision of his government to place his home country on the margins of the developed world, pointing instead at the excellent conditions of future progress if existing knowledge, on a meta-regional level, was pooled together. Once again this example shows that the relationship between core and periphery cannot be defined in absolute terms. Miller's chapter brings into relief the collectivity of knowledge and the fight for its social and political recognition, both of which are determined by spatial hierarchies and attempts to resist them. Her chapter challenges conventional approaches to the creation of knowledge under colonial conditions, showing instead how a peripheral position might invoke particular forms of authenticity that then reveal great creative potential.

Back in Europe, Harry Stopes argues in a chapter on Lille and Manchester around 1900 that global connections do not necessarily pass via capital cities. He demonstrates how a secondary or peripheral position on the national map might form the basis of a global economic or cultural strategy that in turn fosters a strong sense of regional or local identity. The example of the two cities presents a modernity and an experience of globalization that was navigated at a local scale, independent of pre-existing national hierarchies. Reversing existing hierarchies between core and periphery, Stopes illustrates his findings by exploring different forms of cultural representation specific to Manchester and Lille.

The book's third and final section examines ideas and commodities that move between centres and peripheries. Jens Späth looks at the transnational impact of the Revolutions of 1820-3, which turned the Mediterranean from the alleged position of a European backwater into a global centre of constitutional change. Ever since the days of Spain's resistance against Napoleon, the Spanish constitution of 1812 
had assumed an almost mythical reputation among constitutional monarchists around the world. With direct reference to this document, the insistence on constitutional government among members of the revolutionary movement of the 1820s gave birth to a first liberal International. The centre of action was neither Paris nor Vienna, and there was not one centre, but many, including cities such as Madrid, Naples, Palermo and Lisbon. The following chapter by Alessandro de Arcangelis stays in the Mediterranean, discussing how Italian political thinkers have reconciled cosmopolitan with national ideals in order to overcome Italy's perceived marginalization since the early modern period. Their creative intellectual force informed the transnational circulation of European ideas in Italy, while at the same time challenging existing discursive asymmetries. Read together, the chapters by Späth and de Arcangelis demonstrate how hegemonic constructs produced spatial hierarchies that the alleged peripheries could either accept or reject.

Although it examines debates around 1900, Tessa Hauswedell's chapter is directly relevant to contemporary ideas of Britain's changing relationship to Europe and the world, as mentioned at the start of this introduction. Combining a conceptual history approach with a digital analysis of reference cultures, her chapter surveys different junctures at which the British press constructed London as the 'imperial metropolis of the world'. Affecting more countries than just Britain's immediate neighbours across the Channel, those notions of superiority imposed a structure of centre and periphery on the entire world. London, during the second half of the nineteenth century, might have been huge and economically powerful, and its built environment imposing, but Hauswedell's documentation shows that due to Britain's isolated and insular understanding of itself there was little space for the many features that determined spatial hierarchies in the view of Europe's Mediterranean civilizations. In this respect Britain's self-image contrasts dramatically with views elsewhere in the world, with the examples discussed by Späth and de Arcangelis, and indeed with the views exposed at the time by Britain's own second cities, as outlined in Stopes' chapter. Britain's discursive grandeur was at least partly the reflection of an inferiority complex vis-à-vis Europe's old and uncontested capital cities such as Paris and Vienna. In Walter Benjamin's famous words, Paris simply was the 'capital of the nineteenth century', despite its ever-pertinent political crisis and its own discourse of degenerative decline after 1870. Unlike Paris or Vienna, London seemed to be in a position where it had constantly to explain its own status in the world. In this context it is telling that in the British press none of the major cities such as Berlin, Rome or Vienna - or related adjectives such 
as 'German', 'Austrian' or 'Italian' - are present as collocates for the term 'metropolis'.

The final chapter by Hermione Giffard discusses transnational patterns of advertising and consumption in a mid-twentieth-century global context. Reflecting hierarchies of core and periphery as they were established during the age of empire, modern marketing in a postcolonial world finds itself in a position to reverse this spatial order. Directly relating to one of the book's key themes, Giffard shows how the twentieth century reflects and then overturns spatial notions we previously discussed for the nineteenth century, where local consumers in the global periphery determine economic decisions in centres of wealth and political power. Global companies are forced to adapt to the reversal of pre-existing hierarchies. Meanwhile, she presents an example of multinational companies located in smaller countries that do not represent the political and economic core of the global economy. Showing parallels to some of Stopes' findings for the period around 1900, Giffard's chapter exemplifies how the local and the global interact, and how the global is enacted through the local.

Taken together, the chapters of this book discuss a chronological range that takes us from the medieval period into the twentieth century, covering much of Europe, the Western hemisphere and parts of Asia, while also referring to the role of the global South in conceptualizing spatial hierarchies. Examples of economic development and changing structures of political power stand next to studies of intellectual exchange. Religion represented an important and very topical focus of the debate at the conference on which this collection of essays is based, but it is less clearly reflected in the chapters that follow, leaving an important field for future and more specialized investigation. Although all authors write in historical perspective, their arguments are based on a range of expertise from different disciplines of the humanities and social sciences. The way in which they engage with notions of centre and periphery on a global scale does not suggest that, as analytical categories, these concepts are redundant. Instead, they demonstrate how, as products of human agency, centre and periphery are conditioned by mutual dependencies. They reveal constantly evolving asymmetries between them. Most importantly, they show that centre and periphery do not represent absolute categories. Instead, they present subjective categories defined by their discursive context. This is not to say that they are not real, but that in history, realities are shaped by the mind. In this sense the book is an invitation to understand each spatial hierarchy not as a fact, but as a preference of perspective. 
This book is based on papers and discussions of a conference held at University College London in June 2016, a collaboration between the UCL Centre for Transnational History and the European research project 'Asymmetrical Encounters', based at the University of Utrecht, UCL and the University of Trier. The organizers of the event are also grateful for the financial support they received from the UCL European Institute and from UCL's research programme Grand Challenge Intercultural Interaction. The editors of this book would like to thank all speakers and chairs for contributing their thoughts to our discussions, especially those who participated in the publication of this volume. With its wide thematic scope, this book will hopefully be relevant to researchers from across the globe, which is why we publish it in Open Access.

\section{Notes}

1. Vincenzo Gioberti, Del rinnovamento civile d'Italia. Paris and Turin: Giuseppe Bocca, 1851, Vol. 1, 145; see also 199, 276.

2. Gioberti was among the first political thinkers in Europe to use the term 'modernity' (as a noun) to describe changes in the semantics of historical time: Gioberti, Del rinnovamento, Vol. 1, 5.

3. Gioberti outlined his idea of Italy's primacy in his extremely influential political pamphlet $\mathrm{Del}$ primato morale e civile degli italiani. Brussels: Meline, Cans, 1843. There is a strong similarity between Gioberti's emphasis on local characteristics and some of the thinkers Marta Petrusewicz analyses in her contribution to this book. For a more detailed discussion of Gioberti's understanding of Italy's relationship to the world see Silvia Patriarca, Italian Vices: Nation and Character from the Risorgimento to the Republic. Cambridge: Cambridge University Press, 2010, 25. See also Axel Körner, America in Italy: The United States in the Political Thought and the Imagination of the Risorgimento, 1763-1865. Princeton: Princeton University Press, 2017, 100-7. For a contemporary contextualisation of Gioberti's idea of Britain see idem, "Britain the Sicily of Europe?" Continental Perspectives on Britain's Amour Propre' (Roundtable on Brexit), Contemporary European History 28.1 (2009), Gioberti is discussed further in the chapter by Alessandro de Arcangelis below.

4. See for instance George Athan Billias, ed., American Constitutionalism Abroad: Selected Essays in Comparative Constitutional History. New York: Greenwood Press, 1990. See also the emphasis behind some of David Armitage's readings of American constitutional documents: The Declaration of Independence: A Global History. Cambridge, MA: Harvard University Press, 2007. For a different approach see John G. A. Pocock, The Machiavellian Moment: Florentine Political Thought and the Atlantic Republican Tradition (1975). Princeton: Princeton University Press, 2003. Paola Gemme has argued that assessments of the American constitution's role were often American projections onto other peoples' political experiences: Domesticating Foreign Struggles: The Italian Risorgimento and Antebellum American Identity. Athens and London: University of Georgia Press, 2005. Maurizio Isabella shows how Italian exiles contributed to constitutional debates in Latin America and how their ideas travelled back to the Old World: Risorgimento in Exile: Italian Emigrés and the Liberal International in the Post-Napoleonic Era. Oxford: Oxford University Press, 2009. For a nuanced approach see also Kate Ferris, Imagining 'America' in Late Nineteenth-Century Spain. London: Palgrave, 2016.

5. David Armitage and Sanjay Subrahmanyam, 'Introduction: The Age of Revolutions, c. 17601840 - Global Causation, Connection, and Comparison', in David Armitage and Sanjay Subrahmanyam, eds, The Age of Revolutions in Global Context, c. 1760-1840. London: Palgrave Macmillan, 2010, xii-xxxii. 
6. Umberto Eco, 'Towards a Semiotic Inquiry into Television Message', Working Papers in Cultural Studies 3 (1972): 103-21, 103.

7. Anselm Gerhard, 'Musikalische und unmusikalische Nationalkulturen. Wer benötigt wann eine klingende Selbstvergewisserung?', in: Arne Stollberg, Ivana Rentsch, Anselm Gerhard, eds, Gefühlskraftwerke für Patrioten? Wagner und das Musiktheater zwischen Nationalismus und Globalisierung. Thurnauer Schriften zum Musiktheater, Vol. 26. Würzburg: Königshausen \& Neumann, 2017, 37-53.

8. Christopher A. Bayly, Recovering Liberties: Indian Thought in the Age of Liberalism and Empire. Cambridge: Cambridge University Press, 2011.

9. For a comprehensive account of developments during the nineteenth century see Jürgen Osterhammel, The Transformation of the World: A History of the Nineteenth Century. Princeton: Princeton University Press, 2015. See also Christopher A. Bayly, The Birth of the Modern World 1780-1914: Global Connections and Comparisons. Oxford: Blackwell, 2004; Anthony G. Hopkins, ed., Globalization in World History. London: Pimlico, 2002; Anthony G. Hopkins, ed., Global History: Interactions between the Global and the Local. Basingstoke: Palgrave Macmillan, 2006.

10. Michael North, Zwischen Hafen und Horizont: Weltgeschichte der Meere. Munich: Beck, 2016, $64 \mathrm{ff}$. See also the author's contribution to this book.

11. Akira Iriye, Japan and the Wider World: From the Mid-Nineteenth Century to the Present. London: Longman, 1997, vii ff.

12. See in particular the essays in Catherine Hall and Sonya O. Rose, eds, At Home with the Empire: Metropolitan Culture and the Imperial World. Cambridge: Cambridge University Press, 2006. For issues of race in the relationship between empire and nation see Catherine Hall and Keith McClelland, eds, Race, Nation and Empire: Making Histories, 1750 to the Present. Manchester: Manchester University Press, 2010.

13. John Elliott, The Old World and the New, 1492-1650. Cambridge: Cambridge University Press, 1970. David Armitage and Michael J. Braddick, eds, The British Atlantic World, 1500-1800. New York: Palgrave, 2002.

14. For a recent overview of relevant literature and trends in research see Axel Körner, 'Transnational History: Identities, Structures, States', in Barbara Haider-Wilson, William D. Godsey and Wolfgang Mueller, eds, International History in Theory and Praxis. Vienna: Verlag der Österreichischen Akademie der Wissenschaften, 2017, 265-290.

15. Samir Amin, Unequal Development. New York: Oxford University Press, 1972. André Gunder Frank, Dependent Accumulation. New York: McGraw Hill, 1978.

16. See for instance Paul Knox, John Agnew and Linda McCarthy, The Geography of the World Economy. New York: Routledge, 2014.

17. See Terence K. Hopkins and Immanuel Wallerstein, World-Systems Analysis: Theory and Methodology. Beverly Hills, CA: Sage, 1982. Immanuel Wallerstein's first application of this model analyses the early development of a world-capitalist economy in the sixteenth century: The Modern World System, I: Capitalist Agriculture and the Origins of the European World-Economy in the Sixteenth Century. New York: Academic Press, 1974.

18. Marta Petrusewicz, Latifundium: Moral Economy and Material Life in a European Periphery (1989). Ann Arbor, MI: University of Michigan Press, 1996.

19. Kirti N. Chaudhuri, Trade and Civilisation in the Indian Ocean: An Economic History from the Rise of Islam to 1750. Cambridge: Cambridge University Press, 1985. Kirti N. Chaudhuri, Asia before Europe: Economy and Civilisation of the Indian Ocean from the Rise of Islam to 1750. Cambridge: Cambridge University Press, 1990.

20. See for instance Kenneth Pommeranz, The Great Divergence: China, Europe, and the Making of the Modern World Economy. Princeton: Princeton University Press, 2000. See also R. Bin Wong, China Transformed: Historical Change and the Limits of European Experience. Ithaca, NY: Cornell University Press, 1997.

21. For an overview of Atlantic history see Manuela Albertone and Antonino de Francesco, eds, Rethinking the Atlantic World: Europe and America in the Age of Revolutions. London: Palgrave Macmillan, 2009.

22. Bayly, The Birth of the Modern World, passim.

23. Andreas Eckert, 'Afrika und die Welt: Afrikanische Geschichte und Internationale Geschichte', in Barbara Haider-Wilson, William D. Godsey and Wolfgang Mueller, eds, International History in Theory and Praxis. Vienna: Verlag der Österreichischen Akademie der Wissenschaften, 2017, 449-73, $451 \mathrm{ff}$. 
24. An important impulse for the analysis of mental maps comes from recent work on travel writing. See in particular Wendy Bracewell and Alex Drace-Francis, eds, Under Eastern Eyes: A Comparative Introduction to East European Travel Writing on Europe. Budapest: Central European University Press, 2008.

25. There are obviously exceptions where the analysis is based on a much wider scale. See for instance Frank Trentmann, ed., The Oxford Handbook of the History of Consumption. Oxford: Oxford University Press, 2012. See also the following chapter by Hermione Giffard.

26. See Axel Körner, 'Barbarous America', in: Axel Körner, Nicola Miller and Adam I. P. Smith, eds, America Imagined: Explaining the United States in Nineteenth-Century Europe and Latin America. New York: Palgrave Macmillan, 2012, 125-59. 

Part I

Concepts 



\title{
2
}

\section{Rethinking Centre and Periphery in Historical Analysis: Land-based Modernization as an Alternative Model from the Peripheries}

\author{
Marta Petrusewicz
}

As briefly mentioned in the introduction to this book, the pair set 'core'/periphery' was first applied extensively to the operations of the world economy in the 1960s by scholars and activists who challenged dominant views of development as synonymous with economic growth. The main thrust of developmentalist literature, the contestants claimed, was to analyse the characteristics of those sovereign states that were industrialized and prosperous, in order to establish a model that could be copied by less fortunate sovereign states.

The critics pointed out that the fortunate and the less fortunate sovereign states were not separate, independent entities that happened to be at different stages of parallel processes of development. They were, instead, part of a single ongoing system - a 'world-system' - where 'developed' and 'underdeveloped' were simply descriptive terms applied to the poles of a unified process of development. Beginning with liberal development theorists and reformers, such as Raul Prebisch, and continuing with Marxists like Paul Baran, André Gunder Frank and Immanuel Wallerstein, the new terms 'core' and 'periphery' entered the vocabulary of development literature. ${ }^{1}$ Better than 'development' and 'underdevelopment', they expressed the relational, mutually dependent nature of the pair in a zero-sum game: the more one zone became core-like, the more another became peripheral. The power aspect of this relationship was expressed by André Gunder Frank's ‘development of underdevelopment'. ${ }^{2}$ 
As 'core'/"periphery' is a relational concept, one should be careful not to associate this shorthand with any permanent list of traits. 'Core'/"periphery' refers always to an unequal relation, but the inequality may be expressed in changing forms. In fact, the commodities involved in the exchange have changed dramatically over time, especially between industrial and agricultural products: what were core products would become peripheral, and vice versa. Most of the time, the 'coreness' /'peripherality' had to do with the wage and profit levels of each product as well as with degrees of technical sophistication.

The full implications of the 'core'/"periphery' relationship can only be observed in an integrated world economy, integration that started with the onset of the modern world-system and reached its apex in the late nineteenth century. ${ }^{3}$ Only then, in parallel with the new imperialism, was the dogmatic view of development as a unique progressive process consolidated. Until then, across the world, different paths of development were envisaged, and none of them yet perceived as inherently core or peripheral.

The case considered here is that of nineteenth-century Europe and its internal peripheries in the period preceding the consolidation of the political economy dogma. In that time and place, a peripheral alternative model of modernization was elaborated and implemented by a transnational cohort of rural modernizers. That nineteenth-century Europe had within it vast internal peripheries is a well-known fact, though maybe less well known is the extent to which they were rural and underdeveloped. Developmental theory views them as having been in the process, however slow and contradictory, of catching up and transitioning to successive stages of the prescribed road. Instead, I will show here how the elites of those peripheries, conscious of the risks of dependency, undertook in that period a number of modernizing projects that were land-based and different from what they referred to as 'Manchester civilization', a paradigm of modernization based on urban concentration, class polarization and mass factory production. Even less known is the use these elites made of political economy, the hegemonic reference culture at that time.

Without providing a systematic comparison, this chapter is based on an extensive study of modernizing elites in four countries situated at the outskirts of nineteenth-century Europe: Ireland to the west, Norway to the north, Poland to the east and the Kingdom of the Two Sicilies to the south, in the period that runs roughly from the Congress of Vienna in 1815 to the 1860s. These areas, integrated into the European world 
economy in ways in which, for example, Russia or Turkey were not, were representative of the peripheral condition for the following reasons: ${ }^{4}$

- they were topographically peripheral in that they constituted the outermost regions of Europe.

- they were structurally peripheral: as producers of foodstuffs and raw materials, their economic activities commanded only a very small share of the total surplus produced within a commodity chain.

- they were politically peripheral in that they were dominated by other free states, as colonies or semi-colonies: Ireland had been, since the 1800 Act of Union, a fully integrated colony of Great Britain; Poland was, in 1795, definitively partitioned among Austria, Prussia and Russia; Norway had passed, in 1814, from an oppressive colonial dominion by Denmark, to a less oppressive but still colonial dominion by Sweden. The Kingdom of the Two Sicilies, although an independent state, had a relatively low degree of autonomy, being treated by both Great Britain and Austria as a dependent territory.

- their indigenous state machinery, where it existed, was weak. State managers did not play the role of coordinators of a complex industrial-commercial-agricultural mechanism, but were rather simply one set of landlords among others, with little claim to legitimate authority over the whole.

- their class system was dominated by the binary 'lords'/"peasants', as the urban bourgeoisie was small in number and often composed of foreigners.

With the bourgeoisie culturally insecure, and peasants poor and mostly illiterate, land-owning elites - though deprived of political power retained an uncontested cultural hegemony. If change were to occur, landed elites were its only possible agents.

These elites proposed a model of modernization which was based on land, agriculture and, in general, on what was perceived by these followers of Smith, Vico and Herder as a vocation of the given territory, its natural and historical suitability to a given path of development. The choice of an agricultural path was not as backward-looking as it might appear from a later perspective. As no path of development was taken as inherently peripheral, in the sense of precluding the ascent of a given region to core position, a land-based one made sense in Prussia as well as in Calabria. In his 1987 'Capitalist Development in Hostile Environments', Giovanni Arrighi identifies three pathways to wage labour 
in late nineteenth-century Calabria, the poorest region in the newly unified Italy: commercial citrus production in the area of Gioia Tauro, the grain-livestock latifundia in the Crotonese, and the subsistence-oriented peasant household economy in the Cosentino. ${ }^{5}$ He names them, respectively, the 'Swiss road', the 'Prussian or Junker road' and the 'American or farmer road', to stress analogies with other historical instances in which such pathways led countries to ascend to core position.

All these roads were, indeed, possible in the eighteenth-century version of the 'core'/"periphery' relation. Adam Smith's invisible hand of the market allowed for multiple pathways to the prosperity of nations: agricultural or industrial production, as long as it followed the vocation of the territory, could assert itself on equal terms in the benevolent international market. ${ }^{6}$

By the early nineteenth century, the onset of the period under consideration here, the terms of the 'core'/"periphery' relationship had begun to harden, away from Smith's equalizing market vision. Industrial goods were increasingly identified as inherently core products, while primary products were becoming by definition peripheral, to be exchanged on unequal terms in a market dominated by the core areas. Ever more often in the public discourse, peripheral areas were marked as unable to reap more than very marginal benefits from their participation in the world division of labour. The main proof furnished of this inability was the fact that at no point since 1815 had these peripheries been the locus of the most advanced sectors of world production in terms of technology, productive capacity, and focal points of accumulation of capital. This representation was both factually accurate and functioned to subalternize the agricultural vocation of a territory.

This was happening at a time when Europe, as depicted by Jerome Blum, was overwhelmingly rural, noble, traditional and poor. Industrialized areas, on the well-known map drawn by Sidney Pollard, appear as small patches among the rural ones, even within the core states. $^{8}$

This was also a time particularly favourable for agriculture and for landowning elites. The steady growth of population and its food requirements, the long period of rising agricultural prices, import-substitution production strategies implemented by Napoleon, the reigning Romanticism, all this made agriculture attractive, while forcing the pace of agricultural change in market- and profit-oriented directions. Major efforts were put into improving the productivity of staple foodstuffs (grain and other high-starch-content foods) and livestock, and promoting high-yield crops such as buckwheat, potatoes and maize. The slump 
that followed the Napoleonic Wars did not break the enthusiasm for agriculture; agricultural production entered a growth cycle again in the 1830s and more than doubled in the next four decades, with intensive use of the soil, interest in chemical fertilizers, permanent crop rotation and mechanization.

These clear signs of modernization, to which I will return later, coincided with an accelerated effort from the core countries' governments and capitalist interests to expand the amount of unequal exchange in which Europe's traditional societies were involved, aiming resolutely at their further peripheralization. This effort took multiple classical forms: external investments, comparatively lower wages for salaried work, use of peripheries as labour reserve areas, fiscal extraction via indebtedness, and technological and ideological dependence. The point, for the core areas, was to restructure production processes (or to intensify those already begun in previous decades) to keep the peripheries to the role of low-cost producers.

All the above was part of a pattern of peripheral modernization. To ensure optimal circulation of the factors of production (land, labour and capital), modernized structures of bureaucracy were needed, accompanied by weak political superstructures, strong enough to oversee the creation of a relevant economic infrastructure and a personnel training system and to guarantee conditions of order against potential labour unrest, but not to have their own foreign or commercial policies. The model container for all this was the liberal constitutional state. This was what so passionately attracted to liberalism so many in the peripheral areas who were eager to partake in human progress. Many of them, however, also wanted to have a say in defining their role in the capitalist world economy.

They formed a new elite of liberal modernizers, composed mainly of the new bureaucratic and cultural intelligentsia and of landowners oriented to large-scale or specialized export production. On the conservative side, they encountered strong resistance from the cadres of the old order who feared, reasonably, that they might be swept away in the reconstruction of the political system, and who actually did succeed in slowing down the pace of peripheralization. On the bourgeois side, with far greater ease, the modernizers established a dialogue and joint actions with quite a few capitalists, bankers and entrepreneurs. They also envisaged a far more active role for the state, to serve them against the interests of the core. To sum up, liberal agrarian modernizers were trying to fit their countries into their 'peripheral', i.e. agricultural producers', roles in the capitalist world economy, pursuing, however, their own alternative model of modernization rather than imitating the core one. 
With regard to the principal concepts discussed in this volume, their strategy undermined the existing spatial hierarchies imposed on them.

As mentioned above, Restoration Europe was not a bad place and time for a cautious modernizing action by landed elites. The Congress of Vienna restored some of the old prerogatives of the nobility and the landed estates, and guaranteed landowners the security of their possessions. Many reform projects were promoted together by the governments, the landed elites and the intellectuals, including radical transformations in farming, legal reforms, and a transition from communalism to individualism - that is, to a clearly defined private property and freedom of action for individuals. The cooperation between liberal elites and governments had its strict political limits, but some kind of an organic action was possible within them. Old ailing universities, such as Naples, were revived, new ones were opened in Christiania-Oslo, Vilna and Warsaw, and a Catholic one was planned in Dublin. State administration was reformed, railroad constructions initiated, and the development of industry and banking was encouraged. Poland and Norway, within their respective unions with Russia and Sweden, were granted liberal constitutions. Poland even had her own army, until 1830. Ireland obtained the Catholic Emancipation Act in 1829 and a national primary education system was set up under state auspices. The economy flourished, with local textiles, lumber and weapons factories in Poland, and steam-powered mechanized spinning in Ireland.

The monarchs were ready for collaboration with local landed elites as they were the only indigenous partners possible. The elites were ready too, despite political disagreements, because they needed some occupation, given that their traditional jobs - in the civil service and military were now closed to them. As the leading Polish modernizer, Count Andrzej Zamoyski, put it: 'la noblesse doit aujourd'hui se mettre à la tête d'améliorations intéressantes pour le pays, privée qu'elle est d'autre emploi'. ${ }^{9}$ The new generation of peripheral modernizing landowners in Poland, Ireland and the Two Sicilies renounced, for the time being, the insurrectional efforts of their fathers - protagonists of the 1790s uprisings, of wars and of long periods of exile - and opted for prudence, gradualism and moderation.

Thus, modernization at a pace different from the core became the liberal-conservative elites' political, economic and educational project. At its centre stood the land, in a coherent vision of how land-based modernization could bring about moral redemption and eventually become a way of achieving national and political sovereignty. In a way, it was an attempt to slow down or invert the impact of what the economist Karl Polanyi called the 'great transformation', i.e. the extension of the market economy at a pace 
that no 'traditional' society could bear without being torn apart. ${ }^{10}$ Versions of such liberal-conservative land-centred visions were widely diffused in the Europe of the time by economists, novelists, poets, philosophers and preachers, but, as projects accompanied by sets of practices often supported by government agencies, they were peculiar to the peripheries.

The process of modernization was to be slow and gradual, with land at its centre, and landed elites in charge. It was to start with the reorganization of agriculture and radiate from there to a pertinent development of local manufacture, and then to the gradual extension of trade. Such transformations would trigger, in their turn, a virtual process of economic, social and moral advancement of Europe's backward areas. ${ }^{11}$

It was to be a 'harmonious' modernization. The word 'harmony' appeared frequently in reformers' writings, in a variety of applications: preserving existing social and family hierarchies; engaging local traditions and knowhow; achieving social (class) harmony; and maintaining harmony between economy and nature, between change and continuity, between art and industry. In Adam Smith's oft-quoted words, this modernization project was to follow the 'natural course of things'.

'Harmonious' modernization was the proclaimed alternative to the 'Manchester civilization' with its permanent class antagonism and monetization of all relations. Again referring to Smith, peripheral modernizers considered the English model as historically 'inverted', as well as socially disruptive and economically unsound, and opposed it in their economic doctrine and geo-historical philosophy as well as in their actions, class protagonism and economic and social measures implemented. Of course, such critiques of the 'Manchester civilization' were widespread even in England itself, by Charles Dickens, Friedrich Engels, Matthew Arnold and Thomas Carlyle, for example, but in the peripheries they were often used in opposition to the interests of the core.

In this sort of dialogue, both sides invoked the same reference culture of political economy, each to its own advantage. ${ }^{12}$ In appearance, political economy references used by peripheral modernizers were the same as those employed by the followers of the Manchester school. Some people were schooled in economics, but the whole milieu read political economy, which was extremely popular at that time. Thus, in reclaiming the agrarian model, they relied upon the authority of Adam Smith, but the 'true Smith' of the 'natural order' and 'natural course' of things.

In the 'natural order', land and agriculture had priority. In Smith's words, land was 'the greatest, the most important, and the most durable part of the wealth of every ... country' (Smith, IV, 9), and the most productive too, as nature assisted labour and capital that were applied to the 
land. Agriculture was 'the original destination of man' and was also 'by far the most advantageous to [...] society' (Smith, II, 5):

Had human institutions ... never disturbed the natural course of things, the progressive wealth and increase of the towns would ... be consequential, and in proportion to the improvement and cultivation of the territory' (Smith, III, 1).

Progress would proceed in a gradual and orderly fashion from local semi-autarkic realities to larger markets: first well-ordered agriculture, followed by the development of local manufacture, followed by the growth of domestic trade, and lastly transport and foreign trade. But in the England of his time, lamented Smith, 'this natural order of things [is being] ... inverted ... into [an] unnatural and retrograde order', dominated by world trade (Smith III, 1).

If in the core areas, in the nineteenth century, Smith's work was increasingly seen as merely an economic doctrine that laid the basis for Jean Baptiste Say's and David Ricardo's iron laws of economy and the ultra-liberal Manchester School, it preserved its centrality in the peripheries. Local modernizers emphasized gradualism and the social responsibility of 'the natural course': industry, manufacturing and trade would follow the modernization of agriculture, which would supply enough foodstuffs to satisfy demand. Progress was to be gradual and slow.

If the main tenets of Smith's teaching, as the peripheral modernizers saw them, were to be preserved, the concerns of the nineteenth century required, however, a modern re-elaboration of Smith. A 'harmonic school' of political economy was emerging in the peripheries, in connection with other schools in Europe. In Norway, Anton Martin Schweigaard and Torkel Halvorsen Aschehoug elaborated in the 1840s a theory of harmoni liberalismen, which gave a sound theoretical grounding to the agrarian modernization alternative. ${ }^{13}$ Like the 'harmonic school', derived from Frédéric Bastiat, harmoni liberalismen was critical of the "English theory' because it was concerned only with economics without regard to 'natural and social laws' as norms for moral behaviour and productive choice. ${ }^{14}$ The harmonic school and harmoni liberalismen aimed, instead, at achieving harmony between population and production. It was from these economists that peripheral modernizers adopted the concept of 'harmony'.

These peripheral modernizers found, however, their own prophet, a nineteenth-century rendition of Adam Smith, in the Italianized Genevan Jean-Charles-Léonard Simonde de Sismondi, the so-called 
'second Sismondi'. Initially an acclaimed laissez-faire interpreter of Smith, Sismondi published in 1819 the Nouveaux principes d'économie politique, ou la richesse dans ses rapports avec la population, a stringent critique of the ruthless, laissez-faire two-class capitalism and a call for agriculture-based progress, an economics for the common good and a hierarchical system of social and economic harmony. ${ }^{15}$ This book was virtually ignored in the core of Europe, but found an enthusiastic following in the peripheries. 'Harmonious modernizers' followed Sismondi's teaching also in the areas of social policy, constitutions, and connections among literature, history and economics.

Of course, both Sismondi and the peripheral modernizers were in many ways the followers of the physiocrats. But on one important point they differed from physiocratic universalism: they advocated 'localization', and were committed to vocazioni territoriali. Each territory, they claimed, had its own local vocation (and its own soul) constituted by morphology, history, anthropology and the Zeitgeist, and this was different in the plains, the mountains and the hills. The eighteenth-century Neapolitan philosopher Giambattista Vico, to whom the Neapolitan modernizers often referred, spoke of progress as specific to a place, its 'physical' and human history, its traditions and its cultural context. ${ }^{16}$ For Vico, none of the established systems of knowledge or civil and political arrangements could be considered a supreme form of development, because each culture and system of knowledge has its own intrinsic historicity and is oriented towards its own ideal model. ${ }^{17}$ Thus Vico provides us with a powerful argument to sustain one of the main arguments of this book: that any concept of spatial hierarchy represents a specific and subjective point of view.

The modernizers strove to understand the 'vocations' of a given territory to find out what economic, technological or social choices were appropriate for it. Agriculture, of course, was by its nature region-specific, but so was the small- and medium-scale industry that they promoted, based on raw materials locally available.

The harmonious land-based development project did not prevail, and after the agricultural depression hit Europe in the 1870s, the project succumbed to the protectionist turn and simply withered away. In postWorld War I Europe, it survived only under the form of utopian 'backto-the-land' colonies, so marginal as to make even historians forget that such a project had been the economic and political choice of landed elites in the midst of the industrious continent and in the central part of the industrious century. With the rise of post-industrial ecological awareness since the late twentieth century, however, and with the fundamental 
switch in the commodities that characterize the core and the periphery, nineteenth-century attempts to find an alternative pathway to modernization are now meeting with renewed scholarly interest. The case of Europe's landed elites taking it upon themselves to slow down the pace of the extension of the market economy to protect society from being torn asunder might be an important part of this as yet untold story.

\section{Notes}

1. For a general outline of world-systems analysis see Terence K. Hopkins and Immanuel Wallerstein, World-Systems Analysis: Theory and Methodology. Beverly Hills: Sage, 1982. Wallerstein first outlined the development of a world-capitalist economy in The Modern World System, I: Capitalist Agriculture and the Origins of the European World-Economy in the Sixteenth Century. New York: Academic Press, 1974.

2. André Gunder Frank, 'The Development of Underdevelopment', Monthly Review, 18:4 (1966): $17-31$.

3. For the most recent contribution to Wallerstein's world-system series, focusing on the nineteenth century, see Immanuel Wallerstein, The Modern World-System IV: Centrist Liberalism Triumphant, 1789-1914. Berkeley: University of California Press, 2011.

4. A similar argument might apply to other peripheral areas of Europe, such as Bulgaria, which was in some ways comparable to Norway; or Romania and Anatolia, comparable to Poland; and Andalusia, comparable to the Kingdom of the Two Sicilies.

5. Giovanni Arrighi and Fortunata Piselli, 'Capitalist Development in Hostile Environments: Feuds, Class Struggles, and Migrations in a Peripheral Region of Southern Italy', Review, 10:4 (1987): 649-751.

6. Adam Smith, The Wealth of Nations (1776), Books I-V.

7. Jerome Blum, The End of the Old Order in Rural Europe. Princeton: Princeton University Press, 1978.

8. Sidney Pollard, Peaceful Conquest: The Industrialization of Europe 1760-1970. Oxford: Oxford University Press, 1981.

9. Andrzej Zamoyski, letter to Leon Sapieha, 1835, handwritten, preserved in the Bibliothèque Polonaise, Paris.

10. Karl Polanyi, The Great Transformation: The Political and Economic Origins of our Time. Boston: Beacon Press, 1957.

11. For a detailed study of such processes see Marta Petrusewicz, Latifundium: Moral Economy and Material Life in a European Periphery, transl. by Judith C. Green. Ann Arbor: University of Michigan Press, 1996.

12. For a more detailed discussion of the concept of reference cultures see the following chapter by Joris van Eijnatten.

13. Anton Martin Schweigaard, 'Forelæsninger over den politiske Økonomi', in: Ungdomsarbeider (Early Works). Kristiania, 1904 [1847]. Torkel Halvorsen Aschehoug, Socialøkonomik: A Scientific Presentation of the Economic Activity of Human Society. Kristiania, 1903-8.

14. Frédéric Bastiat, Harmonies économiques. Paris, 1850.

15. Jean-Charles-Léonard Simonde de Sismondi, Nouveaux principes d'économie politique, ou la richesse dans ses rapports avec la population. Paris, 1819.

16. Giambattista Vico, Principi di scienza nuova. Naples, 1740.

17. For an introduction to Vico's philosophy of history in English see Joseph Mali, The Rehabilitation of Myth: Vico's New Science. Cambridge: Cambridge University Press, 1992. On the relationship between the Scottish and the Neapolitan Enlightenment see John Robertson, The Case for the Enlightenment: Scotland and Naples 1680-1760. Cambridge: Cambridge University Press, 2005. For the economic context of Enlightenment reform in Naples see also Patrick Chorley, Oil, Silk and Enlightenment. Naples: Istituto Italiano di Studi Storici, 1965. 
3

\section{Europe and the Concept of Margin}

Jan Ifversen

\section{Introduction}

'There are historically different ways of belonging to Europe and although the centre of Europe might be difficult to identify, it has several peripheries' - Jacques Rupnik. ${ }^{1}$

There are many ways to conceptualize Europe. Already in the early nineteenth century the French historian and politician François Guizot described Europe as a civilization overarching the national civilizations of Europe. ${ }^{2}$ In the mid-twentieth century, another French historian, Lucien Febvre, described it as a historical entity and a fatherland in his lectures at the Collège de France during 1944 and $1945 .^{3}$ He also emphasized the difficulties of integrating similarities and differences within a concept of Europe. Since then, many scholars, intellectuals and politicians have had to deal with this challenging logic of combining unity and diversity. The political and economic integration of Europe after World War II led to a view of the continent as a supranational unity. Political scientists, however, have often pointed to the complex nature of government structures within the European Union and preferred to talk about multi-level governance to underline the logic. Whether Europe was understood in terms of governance, culture, identity or civilization, differences had to be included. Symbolically, the EU resolved the challenge by adopting the motto unity in diversity in 2000. Jacques Derrida, the French philosopher, proposed a more elegant solution in his plaidoyer for a Europe which will be open to that 'which it is not, never was and never will be'. ${ }^{4}$ Diversity within Europe has been articulated as a paradox or a tension between universal and particular values, between patriotism and democracy, 
between civilization and culture(s), between centres and peripheries. Solutions have ranged from promoting a cosmopolitan Europe "based on a paradigm shift whose principle is that diversity is not the problem, but the solution', as it is stated programmatically, ${ }^{5}$ to a Europe based on constitutional patriotism, a Europe of the nations, to Europe as simply overlapping diversity. ${ }^{6}$ Diversity itself can appear in many different forms. Apart from the nations that traditionally dominate Europe, regions, cultural minorities, or so-called 'others' within Europe - such as migrants and their descendants - can assume this position. In this chapter, I will look at the role of margins within Europe.

The concept of margin belongs to a semantic field which includes similar concepts such as edge, boundary, periphery and fringe. Scores of academic books and articles carrying headings such as Emotions, Language and Identity on the Margins of Europe, The Frontiers of Europe, Edge of Europe, The Other Europe, European Peripheries: Poetics and Politics of Eastern Europe, Capitalist Diversity on Europe's Periphery, The Boundaries of Europe, and European Borderlands demonstrate the importance of conceptualizing differences in Europe as marginality. In this chapter, I will take a closer look at the concept of margin, and how it relates to the larger and complex concept of Europe. I understand margin as both an analytical concept that is used to perceive the paradoxes or tensions embedded in the concept of Europe, and a political concept used to establish positions and map out hegemonies in European politics. The main question I want to address here is why the concept of margin is so effective for understanding Europe and for doing European politics. I will try to answer this question in three steps. The first step is to focus on margin as an analytical concept, and without further ado choose this word as a header for reflections on marginality. A quick glance at the academic literature on asymmetrical differences reveals that at some point periphery seemed to have been a more popular academic term than margin when discussing relations to the centre. However, for what it is worth, an Ngram in Google books from 1950 to 2010 clearly shows that margin always had the upper hand. In a second step, I will investigate further the semantic fields and discourses in which margin and related concepts are being formed. Margin and marginality are expressed in a variety of discourses ranging from the psychological malfunctioning of individuals to geopolitical ordering of international systems. Here we will concentrate on discussing the different ways that margins make meaning for (the concept of) Europe. In the third and final step, we move into politics and reflect on the role of margin as a political concept. When margin becomes 
political at a European scale, it enters a field of ideological and strategic articulations about how to be or not be European.

\section{Margin as an analytical concept}

As an analytical concept, margin belongs to a theory of marginality, which reflects on how asymmetrical relations are formed and the effects they have on the different actors and positions. The theory is built around the ontological claim that marginality demands centrality. As Noel Parker succinctly points out, 'without margins (edges), centers (metropolises, capitals) could not be centers; without centers, margins' marginal position(s) could not be identified'.7 This structural logic might sound self-evident, but it is very important for understanding how these two positions are constructed and practised. Logically, centres will have a drive to marginalize in order to establish and stabilize their centrality. In his theory of how spaces are produced, Henri Lefebvre speaks of contradictory spaces characterized by a tension between a 'centrality [that] strives to fulfil its "totalizing" mission' and peripheries. ${ }^{8}$ What characterizes a centre in Lefebvre's view is simply its will to power. This can take the symbolic form of sovereignty, which can be defined in different ways, from the dynastical linking of territories, to the nation state based on a claim of cultural similarity, to the federation grounded in constitutional principles. Or it can be grounded in the ordering capacity - the governmentality - of the institutions. Centres are hegemonic, homogenizing and fracturing at the same time. While we can certainly accept the claim that centres are working under the illusion of eliminating differences, this is not all they do. In more traditional discussions of marginality, margin is not only a social construction following the logic outlined by Lefebvre. It is also a condition that can be measured through a series of indicators. ${ }^{9}$ To be marginal is to be below average on these indicators (for instance GDP, unemployment, level of education, growth rate, income). These mainly economic indicators do not in any way, however, explain why groups or regions have become marginal. Marginalization, which is the process through which marginality takes effect, must rely on a systemic logic of a kind. An economic system can build on exploitation, which produces inequalities. Grand theories of world-systems, of underdevelopment or of capitalism for that matter derive from the assumption that the underdeveloped areas, the peripheries, and the pre-capitalist order were a condition for and a result of the centres' expansion (Lefebvre's totalizing mission). A cultural community can marginalize people that are culturally different. A society functions 
through norms, rituals and value systems that decide on acceptable and less than acceptable behaviour. Whether we choose to explain marginalization as an effect of a system that produces inequality, difference, exclusion or abnormality, we need to include a processual dimension. Until now the analytical concept of margin could be condensed in the following claim: it describes an asymmetrical relation deriving from a logic of centrality, which is linked to a system that produces marginality as a negative condition to be measured.

But marginalization is not simply a systemic process: it must be performed; it involves actors and institutions. Marginalization can be a strategy performed by the centre in order to demonstrate its centrality. Decisions are made that have marginalizing effects. They can be directly political, as in the case of the EU's neighbourhood policy, which is based on a differentiation between countries that are or can become members, and countries that are treated as neighbours of the union; ${ }^{10}$ they can be the result of an economic system which is supported politically; or they can be caused by spatial strategies 'that [make] it possible simultaneously to force worrisome groups ... out towards the periphery'. ${ }^{11}$ In either case, the effect will be to produce or uphold margins. The strategy from the centre perspective is thus always balanced between the totalizing mission of eliminating or downplaying differences and the need for margins in order to symbolically uphold centrality. A kind of pluralism - a unity in diversity - is thus established, which links diversity to marginality. The strategy is not simply to exclude, in which case the margin would be completely external, but to create negative marginalization. If we return to the example of the European neighbourhood policy, we can say that neighbours are not just excluded; they are less than members, but more than strangers. I will return to the function of this in-betweenness in a moment.

\section{Positive marginality}

But we can also change perspective and look at marginalization as a strategy performed by the margin. The margin can respond or even resist. Examples of resistance are well known. So-called ghettos in urban areas can respond to marginalization by establishing alternative systems of ordering; at the symbolic level, margins can challenge the identity politics of the centre, as in the case of ethnic minorities demanding recognition of their language and more broadly their culture. Resistances are active strategies to counter the centre's strategies. We must not forget, 
however, Noel Parker's conceptualization of margins as places 'where the centre's ordering capacity begins to ebb out'. ${ }^{12}$ In pre-modern geopolitics, such places were often defined as marches, that is, areas where the centre was not in control, and where sovereignty was less clear. ${ }^{13}$ This lack of control is a precondition for imagining marginality as a performative act, or what Noel Parker calls a theory of positive marginality. ${ }^{14}$ I will draw on his theory to add an extra dimension to the concept of margin. Positive marginality combines the structural challenge embedded in the margin (the centre needs it to establish its centrality), the waning power of the centre in the marches (there are limits to what the centre can do) and the potentials of the margin to act. To study positive marginality is thus also to study how the centre performs its centrality.

How the margin can act in various ways obviously depends on the force of the centre, and of how the margin more specifically is being constructed. Some margins are primarily constructed within a cultural discourse; other margins are defined politically or economically. At this stage, I will, however, not consider the discursive variable when discussing positive marginality. Following Parker, we can observe two general dimensions of positive marginality. One is concerned with the tactics that actors in the margin use to gain benefits from the centre. The other is of a more existential nature and concerns the articulation of identity at the margins. Tactics directly relate to margins trying to get benefits from the centre, for instance in terms of economic redistribution, or of being granted privileges, for instance in the form of special rights. If we stay within the realm of geopolitics and focus solely on the articulation of geostrategies, as Parker does, we can observe how regions will try to navigate in a geopolitical 'geometry' with positions already fixed. In this perspective, regions can try to gain something from repositioning themselves. In cases where there are other centres in the geometry, a region can try to 'play one centre off another'. ${ }^{15}$ One such case could be Scandia in Southern Sweden, which over recent years has been strongly engaged in setting up the Øresund region in cooperation with Copenhagen, with the goal of gaining more freedom from Stockholm.

Regions can also strengthen their bargaining power by claiming to possess a privileged access to the outside. Turkey has a long tradition of using the bridge metaphor to emphasize its links to a world beyond Europe. When preparing for a rapprochement with the EU, the Turkish government positioned Turkey as a mediator between Europe and the Middle East. More recently the Erdogan government has used this position to gain economic benefits from Europe by stopping refugees travelling to Europe through Turkey. Both the tactics of playing off centres and 
of placing oneself in the role of mediator demand a capacity to manoeuvre around similarities and differences. Actors performing marginal tactics in Malmö can choose to highlight the similarities with Denmark and construct a new common region, which might even become a new economic powerhouse. In Turkey, people have long experience of using the bridge metaphor to emphasize not only being connected to other parts of the world, but also representing more worlds and more cultures. ${ }^{16}$ Apart from navigating between two centres inside a specific geometry, or navigating between an inside and an outside, there is at least one more tactical move to be performed by a margin, namely, to imitate the centre and thus eliminate differences. This imitation can be made in order to appear 'familiar, reliable, and easy to deal with' as when Central European actors have selectively appropriated Western values to become more visible. ${ }^{17}$ In this latter case, differences are toned down in order to appear centre-like. The three tactics are presented in Figure 3.1.

There are doubtlessly more tactics of positive marginality to be considered. We can for instance imagine a margin emphasizing the differences from its centre and appealing to an international institution like the UN for protection. This tactic has been used by indigenous people coming together under the heading of the fourth world and arguing against discrimination and exploitation from the centres to which they are connected.

Even if tactics might seem more instrumental and interest-oriented, they tend to slip over into value-oriented actions. Margins that are not embedded in larger identity constructions will appear weaker and less robust. The many political debates about the situation of poorer and less developed regions within a country have clearly demonstrated how margins fare badly without identity politics. ${ }^{18}$ If we look at positive marginality as identity politics, we immediately have to leave out those cases where a margin is perceived negatively by those belonging to it. We know that young people especially are drawn to cities because they want to live what they consider a more modern lifestyle. Rural areas are perceived as traditional and backward. Although migration is most often caused by economic push factors, the negative perceptions of the region that migrants leave certainly play a role.

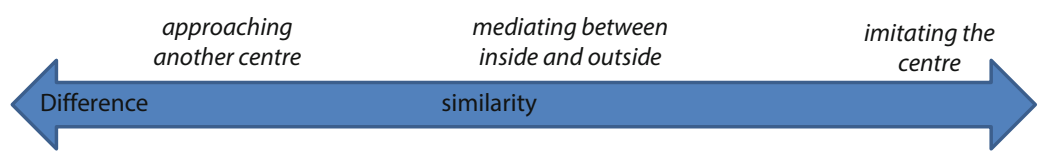

Figure 3.1 Mediating between inside and outside. (Source: author). 
When margins act tactically they try to gain benefits and ameliorate their bargaining power within a setting, which does not radically question the rules and discourses of marginality and centrality. Even if positive marginality involves issues of identity, the game really changes when we move into identity politics. Following Craig Calhoun, I define identity politics as a political practice which evolves around questions of identity. ${ }^{19}$ When political articulations of centrality and marginality are formed around identity we move into identity politics. Whether marginalities can be expressed clearly in identity terms depends on the resources and the discursive possibilities available. Some discourses offer a more powerful repertoire for performing positive marginality. This is the case for identities articulated in discourses of culture and ethnicity. Claiming to be culturally or ethnically different tends to build a stronger case than claiming to be economically disadvantaged. Adding territoriality to the case often makes it even stronger. Regions that are perceived as culturally and ethnically different seem to possess a larger toolbox for performing positive marginality than marginalized groups that are perceived differently.

Before discussing this toolbox at more length I will outline three main scenarios for performing positive marginality as identity politics. The first relates to claims of autonomy. Different arguments can be brought forward to claim autonomy, which again can be granted at different levels. If a margin gains a form of autonomy through special rights or self-government, its relations to the centre change. The federal state is an example of a centrality that becomes merely constitutional and symbolic. The individual states within the federation are only marginal in terms of sovereignty. The symbolic centre is typically reduced to a metonymic expression such as Berlin or Washington. In the case of the EU, where the transfer of sovereignty from the member states is even more limited than in federations, the centre, expressed metonymically as Brussels, tends simply to become an ideological construct by Eurosceptics. There are, however, many examples of margins claiming and sometimes gaining autonomy with reference to identity. These can be national or ethnic minorities with special rights in the states where they live, or regions that have acquired forms of self-government. ${ }^{20} \mathrm{~A}$ second scenario is characterized by margins directly confronting their status as marginal and claiming to be centres in their own right. In order to become a centre, a margin needs not only to mobilize resources, but also to rethink an entire geometry. If the majority of the citizens of Scotland decide to leave the UK, the centrality of the rest of the UK is directly influenced, and so is the geometry of the European Union. We have examples of states being 
divided up in smaller states. In some of these cases, positive marginality was definitely performed, as with the dissolution of Czechoslovakia in 1993, where Slovakian politicians rigorously challenged 'the pragocentrism' of the state..$^{21}$ By gaining independence, Slovakia could claim its own centrality. Both the Scottish and the Slovakian cases involve a high degree of identity politics. In the third scenario, the margin directly challenges the centrality of the centre by imitating it, or by competitive emulation as Parker calls it. ${ }^{22}$ The margin thus claims centrality not only by imitating the centre, but also by arguing that it is more central than the centre. This involves two operations at the same time. The margin must negate the differences from the centre (imitation) and even claim to be expressing the centrality in a better way than the centre. We have seen examples of this in articulations of Europeanness. In his famous article from 1984, 'The Tragedy of Central Europe', Milan Kundera argued that Central Europe epitomized the cultural centre of Europe, a role that Western Europe had completely discarded. Speaking of Western Europe's acceptance of the Soviet control of Eastern Europe, he stated that 'Europe hasn't noticed the disappearance of its cultural home because Europe no longer perceives its unity as a cultural unity'. ${ }^{23}$ Although the tone is pessimistic, he is arguing that Central Europe - presently marginalized by Western Europe due to the Cold War and Soviet hegemony - is in fact the centre of Europe. The rest of Europe has not only forgotten about Central Europe; it has lost its centrality.

\section{The outside and the in-between}

So far I have only discussed marginality within a simple geometry where centre and margin define each other. The geometry can, however, be made more complex. The centre does not only acquire its centrality from the existence of margins, but also by marking out the limits of its reach. As mentioned above, there might be other centres with their own margins. But what is more important here is that the centre also constructs an outside as a negation of its centrality. The margin is bound to the centre, the outside is out of reach and out of control. Where the function of the margin is to establish centrality inside, the role of the outside is to legitimize the totalizing mission.

There are several ways of conceptualizing the outside. Reinhart Koselleck has demonstrated how the idea of centrality can be given meaning by the use of asymmetrical counterconcepts that add universality to the centre. As he states, 'a given group makes an exclusive claim to 
generality, applying a linguistically universal concept to itself alone and rejecting all comparison. This kind of self-definition provokes counterconcepts which discriminate against those who have been defined as the "other". ${ }^{24}$ A traditional asymmetrical counterconcept is the barbarian, who designates both the limits and the negation of civilization. The barbarian is always both less than civilized and the opposite of civilization. This figure appears in different discourses, from the wild man lingering at the fringes of orderly life and the cannibals epitomizing inhumanity to geopolitical discourses of limes and fortresses. The Roman Empire established its limes to mark the borders between imperial order and external disorder. Today the EU is trying to police the Mediterranean to avoid pressure at the gates from immigrants and refugees. Analysts have suggested that the EU's border policies can be viewed as 'a task of containment in the face of a world that is viewed as profoundly alien' comparable to the ancient Roman limes. ${ }^{25}$

The barbarian and the outsider are defined as out of control. They are uncontrollable and thus dangerous. Margins can be viewed as areas where the control of the centre diminishes, but the barbarian and the outsider symbolize the complete loss of control. At times margins can be viewed as in-between zones which are closer to the outside. Since the Enlightenment, Eastern Europe has been viewed as a region which is less civilized than the West. ${ }^{26}$ In nineteenth- and early twentieth-century geopolitics, Eastern Europe was crudely conceptualized as a buffer zone. This concept is used to designate countries as empty, in-between spaces that protect the centre from a chaotic outside. According to William Walters' analysis of the geostrategies performed after the end of the Cold War in Europe, the buffer zone reappeared as a way to locate the Central and Eastern European countries which would insulate them from 'chaotic spaces of the crumbling Soviet empire to the east'. ${ }^{27}$ In-betweenness is typically understood as a condition of being neither one nor the other. In spatial terms you are closer to the limits of Europe. This condition can also be formulated in temporal terms as not being fully European yet. Some scholars see the enlargement of the EU to the east as a process based on a threefold division of Europe into a European core, a Europe to the East which is not yet fully European, and an Eastern periphery that is excluded from being European..$^{28}$ The same designation of in-betweenness has been used to describe the south of Europe in the wake of the refugee crisis: 'The 'South', the other Europe, isn't fully European as it still stands with one foot in the Third World or at any rate serves as an entry gate for the latter. ${ }^{29}$ Some scholars choose to speak of margins as liminal others, borrowing from the anthropologist Victor Turner's famous 
analysis of rites of passage as being betwixt and between. ${ }^{30}$ While Turner viewed the liminal as a marginal and secluded phase that members of a community had to go through to be fully initiated, Morozov and Rumelili reduce it to a hybrid within identity politics characterized by being partly self/partly Other. ${ }^{31}$ They find this position in the different ways that Russia and Turkey manage their European identities. Liminality can thus broaden our understanding of marginality since it includes a phase of transition (in casu not being fully European), a position of hybridity (being more than one) and a position of transitory exclusion. The latter corresponds to what Turner calls 'the essentially unstructured' state of having nothing. ${ }^{32}$

If we look at this in-betweenness from the perspective of performativity, we can say that both the outsider position and the position of being not fully within the geometry tend towards negative marginality. Because it is often dressed in harsh essentialism, the position of outsider is difficult to negotiate. Take for instance the category of immigrant, which tends to stick to one's descendants, generation after generation. Migrants are outsiders in a situation of permanent transition. As Fatima El-Tayeb succinctly puts it: 'migration appears as always reversible, coming with an expiration date, but at the same time stretching over several generations. ${ }^{33}$ The category of immigrant designates the clearest position of the outsider trying to enter a society. Being stripped of an identity - not fully something, not simply from somewhere else - the immigrant is reduced to the outsider within. This figure is well known in imaginaries of the barbarian intruder. The Roman barbarus could appear in the shape of evil and irrationality within the Roman Empire; ${ }^{34}$ the vampire could migrate from a dark uncivilized Europe and contaminate the citizens of London, the most modern European metropole. The current refugee crisis in Europe has demonstrated how people fleeing to Europe from wars, failing states and poverty have become the ultimate image of the outsider, who is kept in a permanent state of in-betweenness within detention areas and camps created as 'zones of indistinction between inclusion and exclusion'. ${ }^{35}$ In these 'non-places' and 'nowherevilles', ${ }^{36}$ the refugee is reduced to a categorical barbarian without any characteristics apart from being misplaced and dangerous.

At the other end of the scale, in-betweenness can be viewed as a position strengthening positive marginality. In a study of Afro-American female academics at American universities dominated by white males, Mary Alfred notes that marginality becomes a positive attribute, because it makes it possible for them 'to successfully navigate their many cultural worlds'. ${ }^{37}$ They can thus move in and out of identities and uphold 
bi-cultural competences and what Alfred calls 'creative marginality'. ${ }^{38}$ In their analysis of Russia and Turkey as Europe-makers, Morozov and Rumelili point to the active role of marginalized countries in affecting identity politics at the centre. As they state: 'By projecting their own visions of Europe onto the EU, the outsiders impel the insiders to articulate the identity of Europe in a slightly different manner compared to what would be possible without this discursive intervention'. ${ }^{39}$ Turkey is thus challenging constructions of European identity that exclude Islam from Europe, and Russia questions geopolitical imaginaries of an ever-enlarging Europe. While European politicians are trying to externalize Turkey, the answer from the Turkish side could be that the country is actually contributing to European identity by supporting multiculturalism. In the case of Russia, European politicians might exclude the country based on criticism of Putin's authoritarianism, whereas the Russian government will stress Russia's geopolitical role in Eastern Europe.

\section{Discourse and identity politics}

The shaping of marginal tactics and identity politics depends on the discourses in which they are being constructed. Discourses are semantically structured around key concepts, basic concepts and semantic relations, which together with the specific scenography of positions configure nodal points and subject positions. ${ }^{40}$ Even a superficial view of conceptualizations of margin and marginality reveals a host of concepts, some of which we have already mentioned. Concepts such as savage, immigrant, outsider, liminal, fringe, edge, neighbour and hybrid are used in different discourses to denote marginality. They are linked by specific central concepts in chains of equivalences around a nodal point which fix the limits of the discourses. The stabilization of nodal points takes place in a realm of interdiscursivity where several discourses are connected and meaning is contested. Some discourse analysts speak of this process as the effort of turning nodal points into empty signifiers, which on the one hand reduces semantic complexities, and on the other hand valorizes the concept positively. ${ }^{41}$ Discursive stabilizations are, however, always challenged by new experiences and interpretations. These challenges can be explained structurally as the inherent dynamics of semiotics, or as a result of social practice. When nodal points are destabilized they turn into floating signifiers that are floating precisely because they are being contested. The tension between empty and floating signifiers is captured by what Reinhart Koselleck terms 'basic concepts' (Grundbegriffe), which 
are at the same time inescapable within a given political and social language and always also contested. ${ }^{42}$ Part of discursive stabilization is to establish a scenography of different positions available for the actors. Of most importance is the subject position which determines who can be included in the perspective formed within the discourse. By fixing this position the discourse sets the condition for identification and legitimate action. A discourse where Europe is made the nodal point can thus establish the condition - the subject position - from where Europeans can be designated and others can be marginalized or excluded as not European.

As already demonstrated several times, margin and marginality can be expressed in many different ways. The two main sets of coordinates are made up by time/space and identity/resources. Margins are typically seen as spaces or even territories that are placed in a larger spatial geometry. Sometimes distance from the centre is directly taken as an indicator of marginality in what are termed distance-decay patterns. ${ }^{43}$ Marginality can be translated into a temporal scheme and identified with being less developed, less modern or less civilized, or it can be seen as a liminal period within a temporal continuum. The other set of coordinates relates to the character of the margin and the reasons for its marginality. A region can be viewed as marginal because it is constructed as negatively different within a value system of differences, or its marginality can be the result of unequal distribution of resources. Quite often identity and resources are brought together to explain marginality. This is the case when being different leads to forms of exclusion which bar regions from access to resources. Before I take a look at specific discourses of marginality, I need to add a final set of coordinates. Marginality can also be used to characterize specific groups or individuals within a society. Being marginalized means being at a distance from the norms and conventions within a society. Again the coordinates often overlap, as when ethnic groups are categorized and marginalized through identity markers (language, religion and culture).

If we now return to the question of marginality in discourses of Europe, we will have to identify nodal points and chains of equivalences. Even if we can speak of Europe in many ways, the notion of Europe as a continent in a discourse that makes Europe as a continent the nodal point is incredibly long-lived. The reason is that the concept of continent can very easily be connected to concepts which are meta-geographical. ${ }^{44}$ Ever since Herodotus referred to Europe as also a myth and a race, Europe has been perceived as more than a continent. This concept certainly also influences our understanding of marginality within discourses of Europe. Margins are typically placed at the edges of a European centre. With the 
emergence of states in the sixteenth century, Europe became a geopolitical space configured around the nodal point of power balance, which turns margins into smaller states, buffer zones and controlled areas. The expansionist drive of larger European states and empires reduced parts of Europe to an outsider position under their control. The political space, however, merged with perceptions of Europe as a Christian community (respublica Christiana) and later with robust ideologies of civilization. The expansion of the centre could thus be justified as a civilizing mission into less civilized lands. Larry Wolff has masterfully demonstrated how Enlightenment travellers adventured into the ever more uncivilized East. ${ }^{45}$ This intra-European orientalism turned Eastern Europe into a cultural margin of Europe. The same marginalization took place in the north of Europe ${ }^{46}$ and in the far west.

Europe as a civilization became a dominant discourse and ideology in the eighteenth century, but this was soon challenged by the dominant discourse of national culture and the ideology of nationalism. In fact, since the eighteenth century, discourses on Europe have to a large degree been shaped by the tension between a universalizing European civilization and particular national cultures. Even if the discourse of European civilization in the nineteenth century began to include perceptions of pan-European culture, it was constantly challenged by the centripetal force of nationalism. In fantasies produced by Europeanists like Coudenhove-Kalergi, civilization and pan-European culture were even connected to geopolitical dreams of a semi-imperialist Europe nourished by African colonies. ${ }^{47}$ The nationalization of culture within nationalism would, however, not exclude perceptions of European margins. The overarching force of a civilizational discourse in the centre, whether in the form of economic and political liberalism or Europeanism, would still leave room for harsh asymmetries between European nations. After World War I, large parts of Eastern and Central Europe were still marginalized through the forms of orientalism that accompanied the civilizational discourse. ${ }^{48}$ Marginalization of 'the other Europe' continued after World War II and the Cold War division of Europe. ${ }^{49}$ The consecutive enlargements of the European Common Market and later the European Union brought the older margins closer to the economic and cultural centre of Europe, but did not cancel out forms of marginalization. Turkey remained a kind of border zone, defined in cultural terms as less European and geopolitically as being in between Europe and the Middle East. Southern Europe has been pushed back into a liminal status due to the recent euro-crisis, which produced a divide between the economically and thus supposedly morally more advanced and the less 
advanced. The status of Southern Europeans was partly determined by stereotypical views of less responsible and less productive southerners. ${ }^{50}$ The current refugee crisis in Europe has amply demonstrated that the most culturally marginalized are those without lands. Peoples on the move inside Europe have traditionally been the most marginalized of all, since they find themselves outside the standard national templates of culture and identity. The Roma people are a case in point here. ${ }^{51}$ But most marginalized of all are the people trying desperately to reach Europe from the war-torn Middle East or the dramatically impoverished African continent. In some discourses, the whole of Europe becomes a centre a fortress - protecting itself against the invasion at its borders. From a different perspective, the outsiders are putting pressure on the political centre of Europe and, in fact, enforcing the internal marginalization of Southern Europe (Spain, Italy, Greece, Macedonia and Serbia). The impossibility within the EU of sharing the responsibility for accommodating migrants and refugees forced these states to undermine the Dublin regulation and let people move further north. This immediately led to increased charges of Southern irresponsibility.

\section{Margins speaking back}

I have argued that marginality can sometimes be used as a tactic to rock the geometry of centre and margin. Tactics will have to be framed within discourses oriented by specific nodal points and key concepts. The recent crisis scenario in Europe (the euro crisis, the Russian crisis, Brexit, the rise of right-wing populism, the refugee crisis) is providing a context for new marginal tactics. Centres are being challenged in different ways. When tactics move into the sphere of identity politics framed by discourses of culture and civilization, they become powerful tools in changing existing geometries. Following Brexit, the Scottish Nationalist Party is preparing the road for leaving one union to join another, with a forceful rhetoric of independence. Pressured by harsh requirements from the EU in order to receive loans that would avoid a financial breakup of the Greek state, the Greek prime minister, Alexis Tsipras, responded by organizing a referendum and delivering a speech in which he reiterated the claim that Greece always has been the historical centre of Europe and took on the subject position of speaking in the name of Europe's future: 'The crucial choice of the Greek people today concerns the future of Europe, as well as the future of Greece ... They [the Greek people] will seize this moment in history and will send a strong message across Europe, a strong message 
of dignity worldwide'. ${ }^{52}$ By speaking in the name of European democracy against the undemocratic and brutal measures of the centre, Tsipras tried to use Greece's historical aura to portray the policies of the EU - and particularly Germany - as un-European.

From a rather different political perspective, the Hungarian Prime Minister, Viktor Orbán, also spoke in the name of Europe. In a defensive reaction against attempts to introduce quotas for refugees among EU member states, he argued that Hungary was saving European culture from the outsiders: 'Can we shelter people, many of whom are unwilling to accept European culture, or who come here with the intent of destroying European culture? How did we lose and how can we regain the common European homeland to which every nation of the Union including the Greeks and the Germans - can say "yes"?'53 By drawing up a catastrophic scenario in which Europe as we know it is disappearing, Orbán is able - rhetorically - to move Hungary from a more marginal position to the centre. As we have seen, this move reminds us of former attempts - for instance Kundera's - to oppose a European culture firmly embedded in Central Europe to a more superficial Western civilization. Marginal identity politics within Europe are contributing to a changing geometry which in the end might challenge existing centres. But we have also seen many examples of marginal performances without any effect on the centre. Ukraine's failed efforts to become a margin that matters for Europe is a clear-cut example of an outsider that never made it into the liminal position of neighbour. ${ }^{54}$ Neither are 'the expanded margins of Europe's former colonies' in the form of the migrants that have come to Europe over the last 150 years $^{55}$ in a position to perform much positive marginality, even if they have influenced the everyday life of European societies. Some margins are thus able to speak back and play with their centres, while others are silenced and trapped in negative marginality.

\section{Notes}

1. Jacques Rupnik, The Other Europe. London: Weidenfeld and Nicolson, 1989, 22.

2. François Guizot, The History of Civilization in Europe [1828]. London: Penguin Books, 1997.

3. Lucien Febvre, L'Europe. Genèse d'une civilisation. Paris: Perrin, 1999.

4. Jacques Derrida, The Other Heading: Reflections on Today's Europe. Bloomington: Indiana University Press, 1992, 77.

5. Ulrich Beck and Edgar Grande, 'Cosmopolitanism: Europe's Way Out of Crisis', European Journal of Social Theory, 10:1 (2007): 67-85 (quotation from 73).

6. Anthony Smith, Nations and Nationalism in a Global Era. Cambridge: Polity Press, 1995.

7. Noel Parker, 'A Theoretical Introduction: Space, Centers, and Margins, in Noel Parker, ed., The Geopolitics of Europe's Identity. Basingstoke: Palgrave Macmillan, 2008, 3-24 (quotation from 11). 
8. Henry Lefebvre, The Production of Space. Oxford: Basil Blackwell, 1991, 332.

9. Bradley Cullen and Michael Pretes, 'The Meaning of Marginality: Interpretations and Perceptions in Social Science', The Social Science Journal, 37:2 (2000): 215-29.

10. Jan Ifversen and Christoffer Kølvraa, 'The European Neighbourhood Policy? Geopolitics or Value Export', in: Federiga Bindi and Irina Angelescu, eds, The Frontiers of Europe: A Transatlantic Problem?. Washington, DC: Brooking Institution Press, 2011, 45-66.

11. Henry Lefebvre, Henry, The Production of Space, 375.

12. Noel Parker, 'A Theoretical Introduction', 8.

13. William Walters, 'The Frontiers of the European Union: A Geostrategic Perspective', Geopolitics, 9:3 (2004): 674-98 (quotation from 683).

14. Noel Parker, 'A Theoretical Introduction', 11-16.

15. Noel Parker, 'A Theoretical Introduction', 13.

16. Bülent Küçük, 'Borders of Europe: Fantasies of Identity in the Enlargement Debate on Turkey', New Perspectives on Turkey, 41 (2009): 89-115.

17. Noel Parker, 'A Theoretical Introduction', 13.

18. Malene Winther and Gunnar Svendsen, "“The Rotten Banana Fires Back”: The Story of a Danish Discourse of Inclusive Rurality in the Making', Journal of Rural Studies, 28 (2012): 466-77.

19. Craig Calhoun, ed., Social Theory and the Identity of Politics. Oxford: Blackwell, 1994. According to Mary Bernstein, 'Identity Politics', Annual Review of Sociology, 31 (2005): 47-74, the term identity politics was used for the first time in 1979 in an academic text to describe the activism performed by people with disabilities. It only became popular in the 1990s to describe political strategies by mainly ethnic groups seeking recognition, legitimacy and influence.

20. Will Kymlicka, Multicultural Citizenship. Oxford: Clarendon Press, 1993.

21. Carol Skalnik Leff, 'Could This Marriage Have Been Saved? The Czechoslovak Divorce', Current History, 95 (1996): 129-34.

22. Noel Parker, 'A Theoretical Introduction', 15.

23. Milan Kundera, 'The Tragedy of Central Europe', New York Review of Books, 26 April 1984, 33-8 (quotation from 36).

24. Reinhart Koselleck, The Practice of Conceptual History: Timing History, Spacing Concepts. Stanford, CA: Stanford University Press, 2004, 156.

25. William Walters, 'The Frontiers of the European Union', 692.

26. Larry Wolff, Inventing Eastern Europe: The Map of Civilization on the Mind of the Enlightenment. Stanford, CA: Stanford University Press, 1994.

27. William Walters, 'The Frontiers of the European Union', 684.

28. Merje Kuus, 'Europe's Eastern Expansion and the Reinscription of Otherness in East-Central Europe', Progress in Human Geography, 28:4 (2004): 472-89.

29. Etienne Balibar, 'Borderland Europe and the Challenge of Migration', openDemocracy, 8 September 2015 https://www.opendemocracy.net/can-europe-make-it/etienne-balibar/ borderland-europe-and-challenge-of-migration.

30. Viatcheslav Morozov and Bahar Rumelili, 'The External Constitution of European Identity: Russia and Turkey as Europe-makers', Cooperation and Conflict 47:1 (2012): 28-48; Victor Turner, The Forest of Symbols. Ithaca, NY: Cornell University Press, 1967.

31. Viatcheslav Morozov and Bahar Rumelili, 'The External Constitution of European Identity', 29.

32. Victor Turner, The Forest of Symbols, 98.

33. Fatima El-Tayeb, 'The Birth of a European Public: Migration, Postnationality, and Race in the Uniting of Europe', American Quarterly, 60:3 (2008): 649-70 (quotation from 652).

34. Jan Ifversen, 'Civilisation and Barbarism: Discourse, Politics', Identity Working Paper Series. Working Paper No. 1 (2005). Lancaster University. http://www.ibrarian.net/navon/paper/ Institute_for_Advanced_Studies_in_Social_and_Mana.pdf?paperid $=4502199$.

35. Sean Anderson, 'Fugitive Borders', Fabrications, 25:3 (2015): 344-75 (quotation from 363).

36. Sean Anderson, 'Fugitive Borders'.

37. Mary Alfred, 'Reconceptualizing Marginality from the Margins: Perspectives of African-American Tenured Female Faculty at a White Research University', Western Journal of Black Studies, 25:1 (2001): 1-11 (quotation from 5).

38. Mary Alfred, 'Reconceptualizing Marginality from the Margins'.

39. Viatcheslav Morozov and Bahar Rumelili, Bahar, 'The External Constitution of European Identity', 33.

40. Jan Ifversen, 'Text, Discourse, Concept: Approaches to Textual Analysis', Kontur: Tidsskrift for Kulturstudier, 7 (2003): 60-9; Dominique Maingeneau, L'analyse du discours: Introduction aux lectures de l'archive. Paris: Hachette, 1991. 
41. Ernesto Laclau, 'Why do Empty Signifiers Matter to Politics', in Ernesto Laclau, Emancipation(s). London: Verso, 1996, 36-46; Morten Brænder, Christoffer Kølvraa and Carsten Bagge Laustsen, Samfundsvidenskabelig tekstanalyse. Copenhagen: Hans Reitzels, 2014).

42 Reinhart Koselleck, 'A Response to Comments on the Geschichtliche Grundbegriffe', in: Hartmut Lehmann and Melvin Richter, eds, The Meaning of Historical Terms and Concepts. Washington, DC: German Historical Institute, 1996, 59-70.

43. Assefa Mehretu, Bruce Pigozzi and Lawrence Sommers, 'Concepts in Social and Spatial Marginality', Geografiska Annaler, 82 (2000): 89-101.

44. Martin Lewis and Kären Wigen, The Myth of Continents: A Critique of Metageography. Berkeley, CA: University of California Press, 1997.

45. Larry Wolff, Inventing Eastern Europe.

46. Karen Klitgaard Povlsen, ed., Northbound: Travel, Encounters and Constructions 1700-1830. Aarhus: Aarhus University Press, 2007; Dimitrios Kassis, Representations of the North in Victorian Travel Literature. Newcastle: Cambridge Scholars, 2015.

47. Cristopher Leiding Kølvraa (2013). 'Space and Spirit in the Colonial Imagination after the First World War'. In H. Schultz-Forsberg, ed., Zero Hours: Conceptual Insecurities and Ideas of New Beginnings in the Interwar Period from a Global Perspective. Peter Lang. Multiple Europes 53, 107-130.

48. Maria Todorova, Imagining the Balkans. Oxford: Oxford University Press, 1999.

49. Jacques Rupnik, The Other Europe. London: Weidenfeld and Nicolson, 1989.

50. Matthias Matthijs, 'Mediterranean Blues: The Crisis in Southern Europe', Journal of Democracy, 25:1 (2014): 101-15.

51. Zoltan Barany, 'Living on the Edge: The East European Roma in Postcommunist Politics and Societies', Slavic Review, 53:2 (1994): 321-44.

52. Alexis Tsipras, speech to the Greek Parliament regarding the 5July referendum, 28June 2015. http:// www.primeminister.gov.gr/english/2015/06/28/prime-minister-alexis-tsipras-speech-to-parliament-regarding-the-july-5th-referendum/.

53. Viktor Orbán, State of the Nation address, 27 February 2015, Budapest. http://www.kormany.hu/en/the-prime-minister/the-prime-minister-s-speeches/the-next-years-will-be-abouthardworking-people.

54. Timothy Snyder, 'Edge of Europe, End of Europe', New York Review of Books, 21 July 2015. http://www.nybooks.com/daily/2015/07/21/ukraine-kharkiv-edge-of-europe/.

55. Tony Judt, Postwar: A History of Europe Since 1945. New York: Penguin Press, 2005, 8. 


\section{4 \\ After Identity: Mentalities, European Asymmetries and the Digital Turn}

Joris van Eijnatten

\section{Introduction}

'Send it back to where it came from', said an American talk show host during the 2016 election campaign in the United States. In an episode of 'Full Frontal', Samantha Bee referred to what she called Donald Trump's un-American 'brand of right-wing, racist, anti-immigrant demagoguery'. The place of origin she had in mind for this unsavoury ethics was Europe. ${ }^{1}$ Whether or not racism was actually part of the American election campaign is not of concern in this chapter. Rather, the focus lies on Samantha Bee's suggestion to send racism back to Europe, a proposition that is part of a long-standing tradition of American anti-Europeanism. ${ }^{2}$ Bee made use of a common trope according to which the good things in the United States are American and the bad ones European. In her argument, 'Europe' functions as a discursive construction that serves to make a statement about America rather than Europe. Whether or not she was convinced that all Europeans are racists is not really relevant. The significant point is that whatever Samantha Bee may have imagined America to be does not necessarily correspond to valid, verifiable truths about Europe. Each culture, each group and each individual creates a mirror image of its 'other', just as Americans create an image of themselves by constructing the Europe they like or dislike. We call such self-reflecting mirror images 'identities'. 


\section{The Self and the 0ther}

In theorizing identities, scholars of cultural history commonly employ the well-known concept of the 'Other', popularized in the wake of, among others, cultural studies (Stuart Hall), literary theory (Edward Said), postmodern philosophy (Jacques Derrida), postcolonial theory (Homi Bhabha) and feminist theory (Judith Butler). On a theoretical level, the notion of 'othering', or the conceptual pairing of 'identity' and 'alterity', assumes that a Self constructs its own identity by identifying what it is not in order to identify what it is. "Whatever is being distinguished must be distinguished from something which, in turn, must be distinguished from it. Thus all distinguishing also makes visible that from which something is distinguished. ${ }^{4}$ Gadamer's logic is compulsive. Making distinctions is a hermeneutical and epistemological precondition for understanding the world. The claim is predicated on several assumptions: that distinctions can be made, that there is an Other, that the Self possesses the ability to recognize it, and that eliminating or changing the Other alters the Self. America is identifiable as America in part because of the presence of Europe; removing Europe from the world-historical equation will, according to the theory, modify America's view of itself. Such tropes are familiar. They stand in a long tradition that includes Said's well-known interpretation of the Orient as what the Occident is not, that is, as the Occident's negative Other. ${ }^{5}$ We instinctively sense the plausibility of these tropes.

Identity, then, is based on discursive distinctions between the Self and the Other, leading to their mutual reification (the Self is never the Other) or to their confluence in multiple, hybrid, fluctuating identities (othered Selves and selved Others exist in all kinds of varieties). In cultural studies, theories of identity have been grounded particularly in the conjecture that identities (especially religious, national and other group identities) are constantly mutable, or so multifarious that they are practically impossible to pin down. ${ }^{6}$ Theoretically speaking, this conjecture is not necessarily false. On the other hand, it is difficult to ascertain its practical value. Why differentiate ad infinitum? Most theories of identity have been put forward by academics and intellectuals living in a cosmopolitan comfort zone, by theorists who have had little to lose, in terms of status and security, from affirming the transience and changeability of identities, even while they had much to gain by it in terms of knowledge and inspiration. It is this intellectual elite that, since the 1980s, has developed an extensive array of theories and methods that has fostered 
the fragmentation of perspectives on the world. The postmodern preoccupation with diversity has nurtured the recognition of difference and the deconstruction of grand narratives in a period of extreme flux, during which both emancipatory movements and the persistent flows of migrants have brought identity politics to the fore.

In political practice, on both the left and the right, the role of identity politics has now become problematic. One of the basic premises of the multicultural society since the 1990s has been the claim that identities are under continuous construction. But even if it were true that individuals, groups of people or even whole societies derive their self-image from the continuous affirmation of distinctions, and that all distinctions vary, it is doubtful whether they would find much existential surety in doing so. Can and do people actually cope with identities in never-ending flux? Developments in the public sphere in today's world, ranging from the rise of populism to the so-called democratic deficit, seem to cast ample doubt on the cogency underlying this form of emancipatory multiculturalism. The opposite assumption, the idea that identities are fixed, is needless to say at least as problematic. The resurgence of nationalism since the 1990s has been predicated on the questionable supposition that identities are stable, offering emotional security on the basis of misinformation. In both cases, identity politics has reached its limits.

This chapter seeks to argue for a revisionist return to a pre-constructivist conception of identity, or rather for a non-constructivist alternative to identity. The question at stake here is whether we can conceive of Selves (such as Europe or America) not as ephemeral constructions that exist by beholding others, but as relatively self-determined, semi-permanent entities that exist by beholding themselves. Whether the belief in ever-changing, multiple identities is warranted or not is not my concern. There is no going back, even if one should want to, and it is not my intention to argue that we should avoid doing justice to diversity. The question is whether there are other and perhaps better ways of affirming group cohesion than by focusing on identities, since this approach has not proved very useful in dealing with today's problems. From a 'progressive' perspective identities are fleeting and end up being impractical constructions; from a 'traditionalist' one they are static and will be discarded as unlikely givens. Both options are as shallow as they are unworkable. More importantly, putting identity theory into practice amounts to drowning in a morass of subjectivities, since there are as many identities as there are subjects, and any subject can claim any identity. Identity has become a never-ending, highly politicized story. 
Three or four decades after the cultural turn, identity has run out of steam. We need an alternative. Suppose, therefore, that we look at cultures from the inside out, rather than the outside in. Imagine that we start out from the Self in relation to itself, rather than the Self in relation to an Other. What would such an approach mean for larger territorial entities and for the asymmetries they involve?

\section{Collective mentalities}

It is clear that the stable entities and imperturbable structures that once helped us to organize the past, such as nations and civilizations, are no longer credible. We know that even the most robust entity of all, the nation state, is unable to control its own political, social, economic and cultural functions, let alone its destiny. It has become porous: substantial parts of its sovereignty and power have been transferred to supranational organs or non-state actors, ranging from international terrorists to multinational companies, while domestic cultures are influenced to a larger extent than ever by lobbyists, religious leaders and politicians abroad. If only for the sake of realist politics, supranational entities have become the main viable alternative to nation states. The irony is, however, that they are extremely fragile and lead a problematic existence. That is not true in all cases. If we regard the United States in the spirit of Frederick Jackson Turner as a federal conglomeration of nations then it, too, can be counted as a supranational entity. ${ }^{7}$ But 'America' appears still to resonate among the vast majority of its population. Europe hardly echoes as strongly among Europeans as America does among Americans. Yet there is a paradox here that seemingly involves the concept of 'identity'. Most citizens of European countries, insofar as they have internalized the culture of the societies they live in, sense that they are European rather than American or African or Asian. Europe really does exist in the minds of people. The Eurobarometer and other surveys of people's opinions about Europe make that clear. ${ }^{8}$ How can we explain this paradox?

We need not have recourse to the notion of identity to understand why Europeans feel European without being overtly emotionally attached to Europe as a cultural or even political entity. In this respect the idea of a 'collective mentality' may be helpful, a concept developed in the twentieth century by the French Annales school of historians. ${ }^{9}$ Following the ideas originally developed by Marc Bloch and Lucien Febvre, the founders of that school, I want to posit the existence of nucleate, more or less durable conceptions of reality that characterize large groups of 
people over longer periods of time. These collective mentalities resemble an interior monologue of the public mind; they are akin to streams of public consciousness that can best be examined through the dominant data flows in society. Such flows have a constant impact on people, and in the process give rise to a collective mentality as a set of often unconsciously shared ideas. Historically, three such flows have been particularly prominent, at least in the nineteenth and twentieth centuries. The first is religion, which involves participatory rites and rituals that guide individuals from the cradle to the grave; the second is teaching, which entails a flow of information from educational institutions primarily to the youth; and the third is the media, which constitute a data stream from semi-independent organizations to the public at large.

To clarify this attempt at theorizing historical mentalities as an alternative to mutual othering, I will tweak two concepts that are relatively well known to humanities scholars. The first concept concerns the idea of thick description. It is usually attributed to the anthropologist Clifford Geertz; ${ }^{10}$ by analogy, I will use the term 'thin description'. For Geertz a thick description was a meaningful, heavily contextualized depiction of human behaviour. To achieve this, one needed a hermeneutically schooled observer who was closely involved with the empirical material. Just as an anthropologist monitored a ritual, a historian studied old newspapers. But whereas Geertz viewed a thin description mostly negatively as a dry enumeration of facts, I regard a thin description as a depiction of the primary characteristics and fundamental contours of a cultural pattern - such as a mentality.

A second concept that ties into a revised theory of mentalities is that of the 'imagined community'. In his much-cited book Imagined Communities (1983), the anthropologist Benedict Anderson offered an explanation for the emergence of nationalism in the nineteenth century ${ }^{11} \mathrm{He}$ argued that thanks to the large-scale ascent of printed media in the vernacular (rather than Latin), people no longer needed to know each other, let alone physically meet each other, to share a sense of mutual belonging. According to Anderson, national communities arose in the decades around 1800 as a collective consciousness synchronized in particular by periodical media such as newspapers. Because people read similar things at the same time, they imagined themselves to be part of the same national community.

Anderson's imagined community is easy to compare to a collective mentality. In both cases the multiplication of texts and images serves as the source of a sense of community. While an imagined community is based on synchronic reproduction, a collective mentality is grounded in diachronic 
repetition. Whereas the first emerges from ahistorical simultaneity, the second arises from historical iteration. Because people in the past continuously read similar things, they began to be part of the same linguistic, cultural matrix spanning time and space. I call this matrix a mentality; from the point of view of Geertz, such a mentality can be grasped as a thick description. Changes in mentalities occur very slowly; the pace may at times be excruciatingly protracted. That makes mentalities a source of cultural stability, but also one of cultural conservatism. We should therefore be cautious not to 'reify' mentalities, to avoid fixing them in space and time. We could perhaps say that the moral worth of a mentality, and therefore its chances for survival, is determined by the degree to which it is capable of adapting to influences from outside. Healthy and robust mentalities, in other words, are relatively dynamic and subject to gradual change.

This raises the question of how mentalities are related to identities. They are similar in several respects. Both mentalities and identities are embedded in, or derive from, culture, and therefore involve difference. Both evolve over time. At the same time, a mentality is not an identity. As noted above, an identity exists by the grace of the Other. In principle, however, a mentality does not need the Other. A mentality simply is; it is self-sufficient; it is a Self rather than an Other. Yet the fact that mentalities and identities are different things does not mean that there is no relation between them. An important aspect of any robust mentality is the tendency to look beyond itself, not for the sake of 'constructing' its own identity, but to reaffirm itself, or to reaffirm its own understanding of itself. The example mentioned at the beginning of this chapter may suggest that Americans have a distinctive mindset, possibly but not necessarily different from that of Europeans. Part of American identity may lie in the fact that Americans are consciously not European, and in this way their identity is influenced by an Other. But this influence is at best indirect and, pace Said, not necessarily very strong. Presumably Americans would still be distinctively American even if Europe were further outside their purview than it already is. On the other hand, a concerted effort in terms of identity politics, if reiterated over time through the dominant media, would be able to influence an existing mentality. Like identities, mentalities change, but they change much less rapidly. If the message that racism is inherently un-American were repeated often enough over a longer period of time, that message could well become part of an American mentality. There is a link, then, between mentalities and identities, but it is in many cases tenuous.

This indirect influence is apparent in the way mentalities - defined as cultural matrices spanning time and space - mutually influence each 
other. They can act as each other's 'reference cultures'. Samantha Bee's racist Europe is an example of a culture ('Europe') acting as a reference to another culture ('America'). A reference culture is a cultural model that for decade after decade, if not century after century, has been imitated, adapted or resisted by other cultures. Reference cultures have been defined as "mental constructs or "cognitive maps" that do not necessarily represent geopolitical realities with the internal hierarchies and recognizable borders that usually accompany them.. ${ }^{12}$ They are typically established and negotiated in public discourse over many generations, and thus depend, like mentalities, on iteration. Clearly, a culture will only have the ability to act as a reference culture if it is historically, politically, economically and/ or militarily (and in some very rare cases, also morally) powerful. It must be a model that other cultures for some reason look up to. For a culture to be accepted as a reference culture, it must be recognized as part of public discourse, a status which it will only be able to gain if it is iteratively present in the public domain. In this sense, the acknowledgement of a culture as a reference culture can become part and parcel of a mentality. Americans may acknowledge Europe as a negative reference culture (for instance as a 'racist' model) because it has been integrated into their mentality.

To recapitulate the concepts I have discussed thus far: an identity is a temporally and spatially transient construction that depends on an Other (or on Others); a mentality is a semi-permanent cultural matrix spanning time and space; and a reference culture is a cultural model that may become part of the mentality it is referenced by. Reference cultures are to be found on any level of cultural aggregation but their impact is especially striking on the level of national and supranational entities. Nations and super-nations are based on power structures - political, economic, military or otherwise - which differ in size and strength, so that cultural referencing is likely to involve asymmetries. Hence the most evident form of reference culture derives from the power and status of such formidable nations as the United States and China, or supranational entities like the Soviet Union and Europe.

\section{A digital view of Europe}

As we saw, both the idea of a collective mentality as an imagined community - a sort of Anderson 2.0 - and the process of asymmetrical cultural referencing that influences a mentality, are based on repetition. Mentalities emerge through repetitive broadcasting. This brings me to the use of computers in historical research. The sometimes bombastic language 
used by 'big data' enthusiasts may not be entirely convincing, but no practitioner of the humanities will deny that we live in a digital age and that this world will not be going away any time soon. Actual practice is of course more complicated than pretentious expectations. On the one hand we need to beware of reducing reality to the handling of data by a mere algorithm. Computers are capable of modelling data in extremely sophisticated ways, but at this point in time they cannot in any sense be a replacement for people. On the other hand we cannot help but note that 'big data' is hardly a novelty. Historians have been seeking for patterns in the past since Herodotus, so the call to engage with them is not particularly revolutionary. At the very least, computer-assisted research can serve to look anew for larger patterns (such as mentalities) in larger amounts of data (such as newspaper articles). ${ }^{13}$

I have argued above that mentalities arise from the iteration in public discourse of ideas, points of view, arguments, conceptions, opinions, beliefs, and so on and so forth, that occur and reoccur as part of the dominant data flows in society. For most of the nineteenth and twentieth centuries, newspapers comprised a very significant, if not the dominant, data flow in society, thereby influencing mentalities on a national level. In other words, digitized newspapers likely allow us to examine the content and development of those mentalities. In the final instance a computer is not much more than a glorified counting machine, and the one thing a computer is able to cope with is repetition. It would be logical, therefore, to exploit such frequency generators to map mentalities.

I will offer a simple example of the way computers allow us to chart mentalities, based on the periodicity of newspapers. The example concerns a particular conception of Europe as an aspect of the Dutch national mentality: the idea of rivalry as a common European bond. The historical foundation of European power has frequently been attributed to the fact that since at least the medieval period but more obviously since the sixteenth century, the European continent has functioned as a complex of mutually competitive territories. The idea that not just Europe's rise to global economic and military dominance but its very unity and coherence are to be found in the fact that it is so fragmented may sound a little bizarre, yet it has always been a serious point of view for both intellectuals and politicians wrestling with Europe's 'identity'. ${ }^{14}$ The cycle of war and peace between Habsburg and Hitler, the economic struggles in Europe's history from the Dutch East India Company to the scramble for Africa, and the cultural variety among the European nation states has often been summarized in the dictum, 'unity in diversity'. The dictum was even chosen as the official rallying cry of the European Union 
in 2000, with the intention, obviously, of stressing union over disunion. Be that as it may, we need not look far for a thin description of Europe: the official website of the European Union offers a version of the motto 'united in diversity' in no less than twenty-four languages, ranging from the Dutch in verscheidenheid verenigd to the German in Vielfalt geeint.

Almost two decades later the motto sounds a little like an admission of weakness. It is doubtful, one suspects, whether diversity can function as the basis of a strong polity. But that is not the point. The metaphor of Europe as a family of troublesome and often dysfunctional relatives has frequently appealed to the European imagination. And despite the cynicism it may prompt, there is something to the motto. Friendly competitiveness as a modern, sublimated version of traditional violence was strongly encouraged in the twentieth century, when the various nations got together under European colours in a joint effort to win palms of honour. Some of the earliest examples stem from the period between the two World Wars. In the Interbellum, for example, a rather innocuous and once popular competition between the most beautiful women of Europe began to be organized: the Miss Europe pageant. Newspapers had a field day. The public loved stories about European girls who, thanks to their election as Miss Europe, were actually invited to America, the high point of all pageants. The press lapped up the scandals about winners who ended penniless and friendless and ultimately committed suicide. ${ }^{15}$

The Miss Europe elections were resumed after the Second World War, when they often took place in the former European colonies. In 1952 even Turkey was allowed to supply the loveliest Miss of all. In this respect the Miss Europe Competition resembles the Eurovision Song Contest, which today includes not just Turkey, but also Russia and even Australia. Political and cultural definitions of Europe overlap but they do not coincide: it seems that competitive European culture was more inclusive than the regulated market of coal and steel. It is the sheer extent of this competitive culture across the western edge of Eurasia that makes it constitutive of a twentieth-century thin description. When and how were European competitions covered in Dutch newspapers? How popular were they? Can we assess the impact on the Dutch mentality of the idea of Europe as a unity based on amicable rivalry?

Of the many contests held during the twentieth century, sports competitions stand out in terms of the amount of news coverage they attracted. Newspaper articles frequently mention the word 'Europe' in combination with specific sports, and they do so in a very clear pattern. It is evident from Figure 4.1 that sporting activities did not manifest themselves as a peaceful version of the traditional European melee prior to the Second 


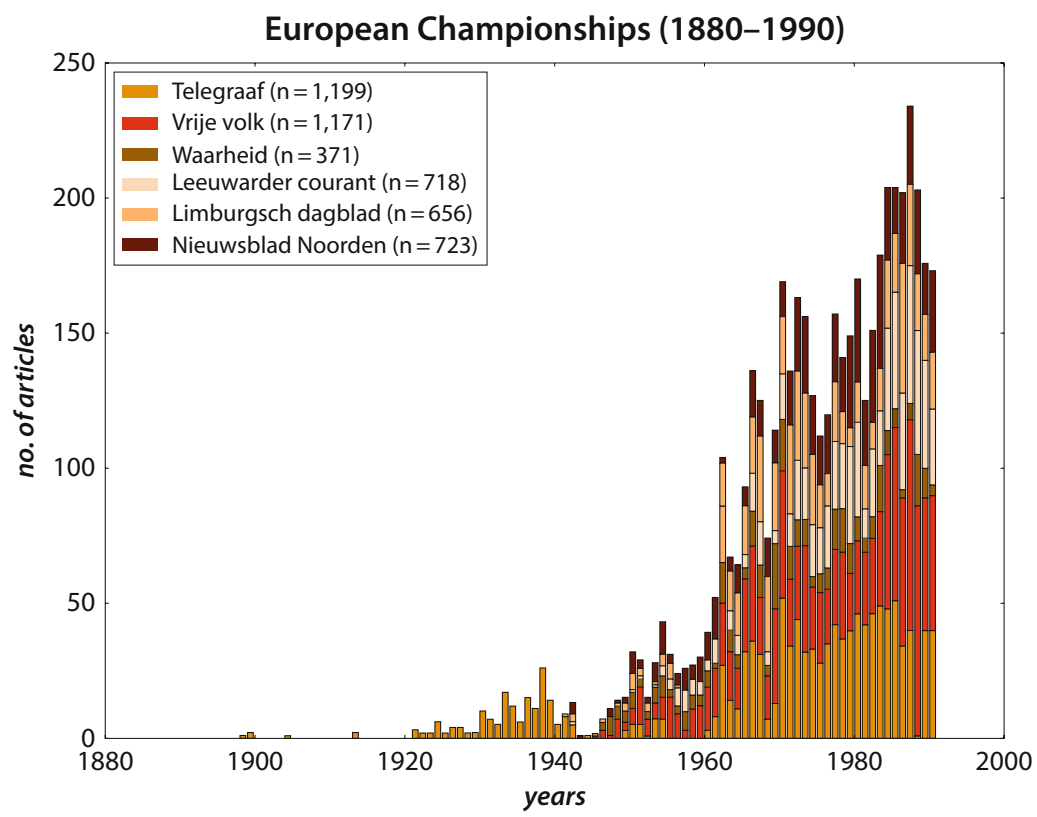

Figure 4.1 Stacked bar chart of absolute occurrences per year for the term 'Europe(e)s(ch)e kampioenschap(pen)' in newspaper articles in De Telegraaf, Het Vrije Volk, De Waarheid, Leeuwarder Courant, Limburgsch Dagblad and Nieuwsblad van het Noorden (1898-1990). Made in Python Matplotlib.

World War. This histogram represents the absolute number of hits for the term 'European Championships' over the twentieth century for six Dutch newspapers. Evidently, Europe became recognizable as a sporting continent only after 1950. The same pattern manifests itself for all articles that mention 'Europe' in combination with major or minor sports, whether we look at athletics, billiards, skating or football (see Figure 4.2).

For Europeans, of course, the prime sporting activity is football, while the key Dutch newspaper is De Telegraaf, a popular tabloid-style daily famous for its sports journalism. ${ }^{16}$ Interestingly, in light of the European Union's official motto, newspaper accounts had little to offer in the way of the Europeanness of football competitions. For example, little if nothing was said about a 'typically European' football style. In the one single instance (out of some 10 million digitized newspaper pages) that Dutch journalists used the exact phrase 'typically European' in relation to football, they quoted a foreigner. The article appeared, rather coincidentally, in De Telegraaf at the very end of what for Dutch football fans would prove to be the most memorable year of the century: 1978, the year in 
Athletics (1880-1990)

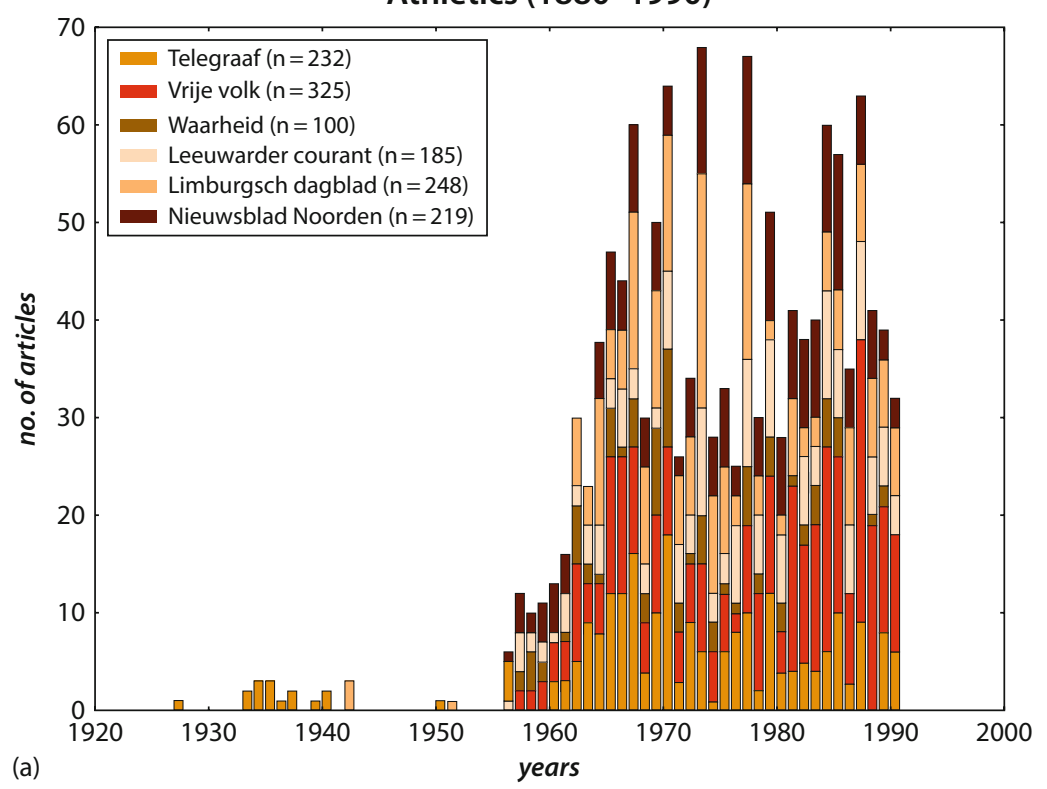

Billiards (1880-1990)

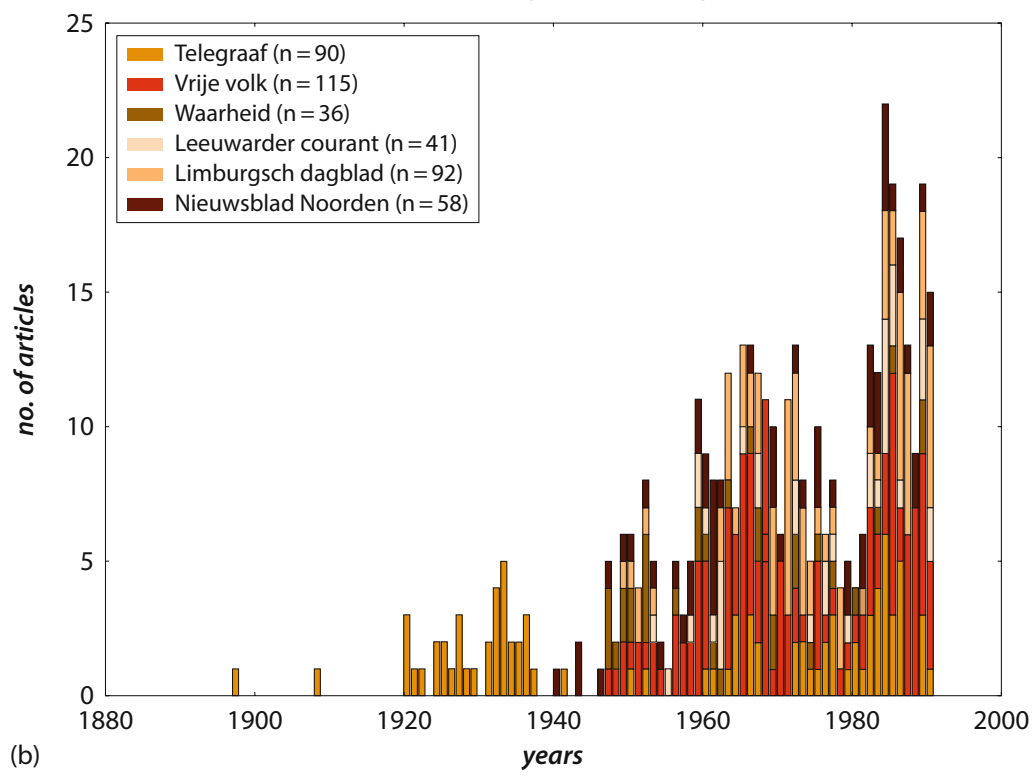

Figure 4.2 (a-d). Stacked bar charts of absolute occurrences per year for 'Europa' in combination with 'atletiek', 'biljart', 'schaatsen' and 'voetbal' in newspaper articles in De Telegraaf, Het Vrije Volk, De Waarheid, Leeuwarder Courant, Limburgsch Dagblad and Nieuwsblad van het Noorden (1898-1990). Made in Python Matplotlib. 
Skating (1880-1990)

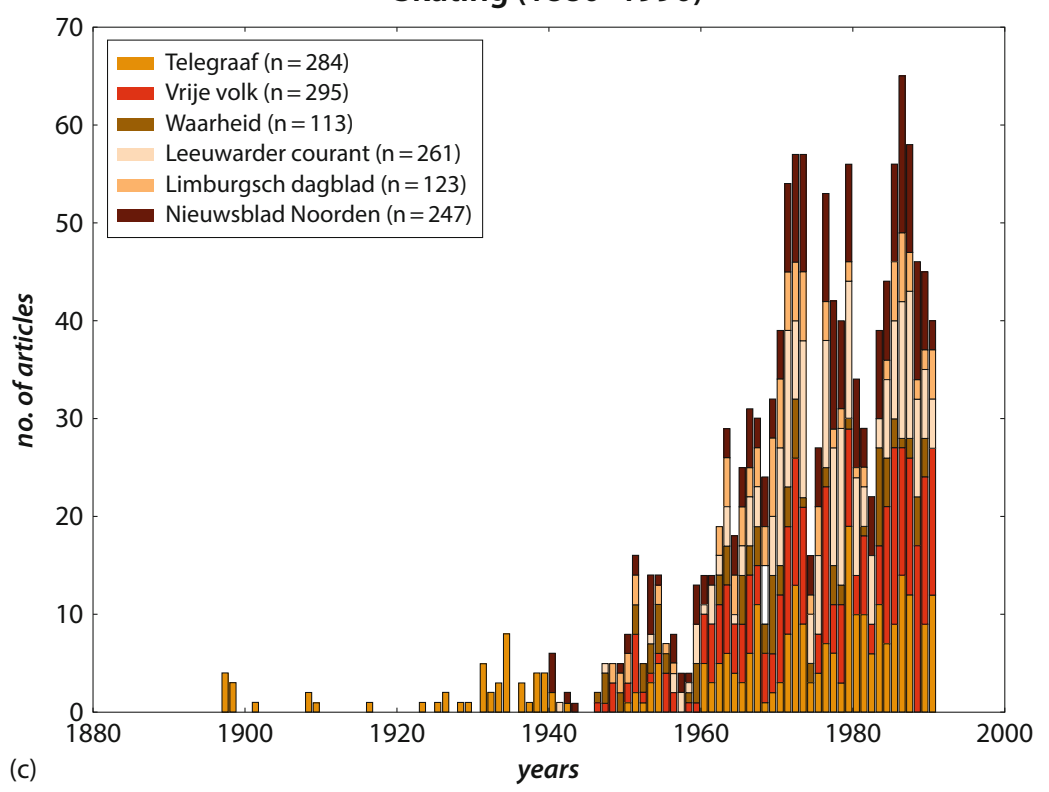

Football (1880-1990)

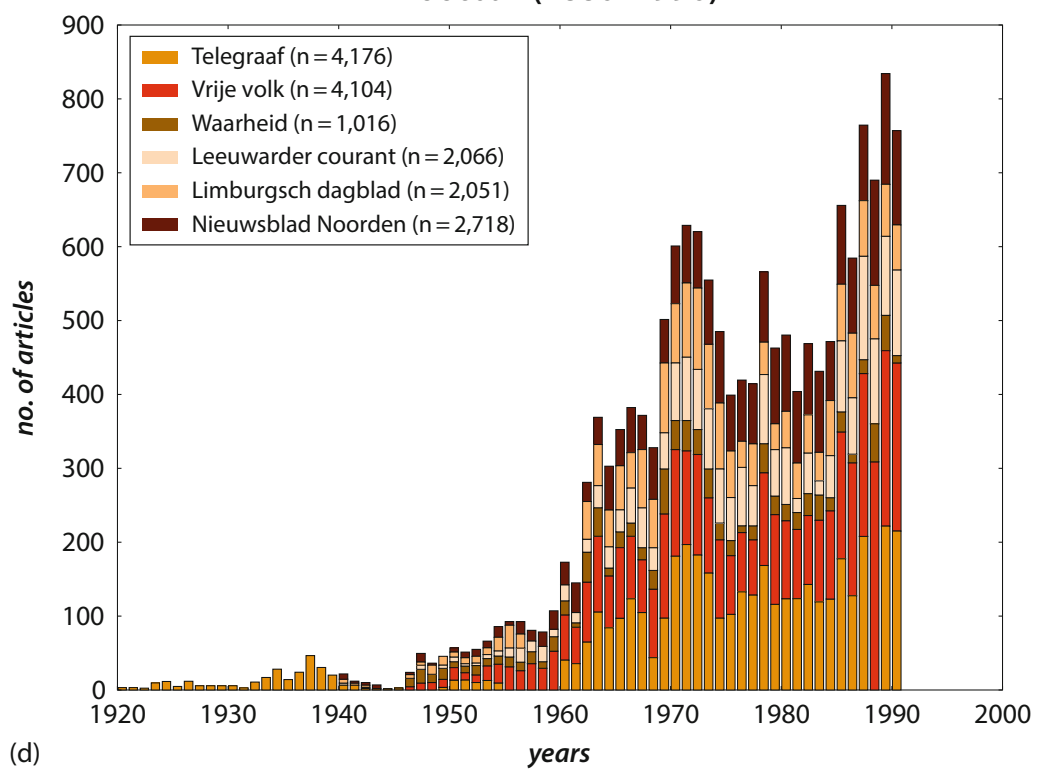

Figure 4.2 (Continued) 
which the Netherlands lost the World Cup to Argentina. In an interview, the Argentinian forward Mario Kempes said:

Dutch football deserves a big compliment. The Dutch play typically European football, but by fits and starts they bring a South American 'touch' to their game. That makes them so unpredictable. Football needs to be well organized on your side. Otherwise you'll never get that far. ${ }^{17}$

Kempes seems to have meant that playing in a well-organized fashion is typical for European football, but the fact that a South American said so brings us back to the kind of argument made by Samantha Bee in repudiating racism as a non-American habit. It is not certain whether the Dutch recognized the attribution: the Self does not necessarily recognize the things ascribed to it by an Other. Presumably the Dutch felt as little called upon to regard their football style as typically European in 1978 as they are inclined to see racism as part of the European identity today. More important, however, is the fact that the notion of a typically European football style did not resonate among the Dutch themselves.

Clearly, no European frame of reference emerges from the newspapers. The question then arises whether newspapers dealt with post-war competitive Europe in relation to its constitutive nations. We could ask whether (and if so, how) the various European countries mentioned in newspapers functioned as reference cultures for the Dutch. How well did the English, the Italians or the Spanish play football? Were their talents solid English stamina, defensive Italian catenaccio or even the Spanish penchant for making sneaky fouls - appreciated as something the Dutch should follow? As I have argued, whether or not the presence of such 'Others' led to the construction of a 'Dutch identity' is not the interesting point. Such contentions tend to lead to never-ending and therefore meaningless discussions about 'whose identity?' and 'which identity?' The more significant question is whether the mutual bonding of European nations through competitive activities led to a sense of Europeanness in the Dutch collective mentality. Surprisingly, however, newspaper accounts had little to offer in the way of this kind of Europeanness. I have not been able to find any significant iterations over a longer period of time of specific national attributes. Applying the phrase 'typically Italian' to football gives us three hits in the complete, ten million-plus data set. One hit refers to a 'typically Italian dish such as macaroni or spaghetti' (served while watching a football game on television in 1990); a second mentions 'the typically Italian exuberance' of the Italian president, who apparently kissed everyone on board the plane that 
was flying him back to Rome after Pisa defeated Ascoli in 1988; only the third condemns the 'typically Italian', unsportsmanlike style of AC Napoli, whose unwilling and uninspiring defensive play 'killed' the match against Ajax Amsterdam in 1970. ${ }^{18}$

The lack of cultural references either to Europe or its constitutive nations leaves us with the mere mention of those nations. Were some sporting countries mentioned more often than others, so that they were eventually lodged in the minds of Dutch readers through constant repetition? The relative frequency with which nationalities occurred over time in football news offers an image of the geographical rather than cultural formation of Europe as an aspect of the Dutch twentieth-century mentality. To ascertain this, we need to chart European football games and plot the historical variants of twentieth-century nationalities mentioned in newspaper articles. Was the Icelandic football team on the Dutch radar at all? How popular were the English? Did sports journalists connect Europe to Russians or Turks or even Egyptians, as their colleagues did with respect to the Miss Europe Pageant or the Eurovision Song Contest? What did this mean for Europe as a geographical framework in the Dutch collective mentality?

Directly after the First World War De Telegraaf established an image of soccer-playing Europe that would hold its ground until the end of the twentieth century. Despite the inevitable variations in charting European football competitions, one thing is abundantly clear: from the outset a central role was reserved for Germany. Moreover, the image of competitive Europe during the 1920s was no different from the image that emerged during the 1970s. The five years from 1970 to 1974 offer a division of football-playing nationalities that is representative of the whole postwar period (see Figure 4.3). The Germans are way up in the charts. Next come the English and Scots, the Italians, the French and the Spanish. The remainder includes substantial parts of Eastern Europe, even during the Cold War, especially Poles, Russians and Yugoslavs. However, although Eastern Europe and Scandinavia may have been present, from a statistical perspective they were quite irrelevant, as were Iceland and Greece.

The result of constant repetition in sports news was an image of Europe represented by a Saint Andrew's Cross of nationalities that had its pivot somewhere in the neighbourhood of Luxembourg, connecting Real Madrid and the Hamburger Football Association with SSC Napoli and the Glasgow Rangers. This Saint Andrew's Cross was established in the minds of Dutch readers as a qualitative, geographical frame of reference. As such it was a significant aspect of twentieth-century reality, internalized in a collective mentality over several decades. 


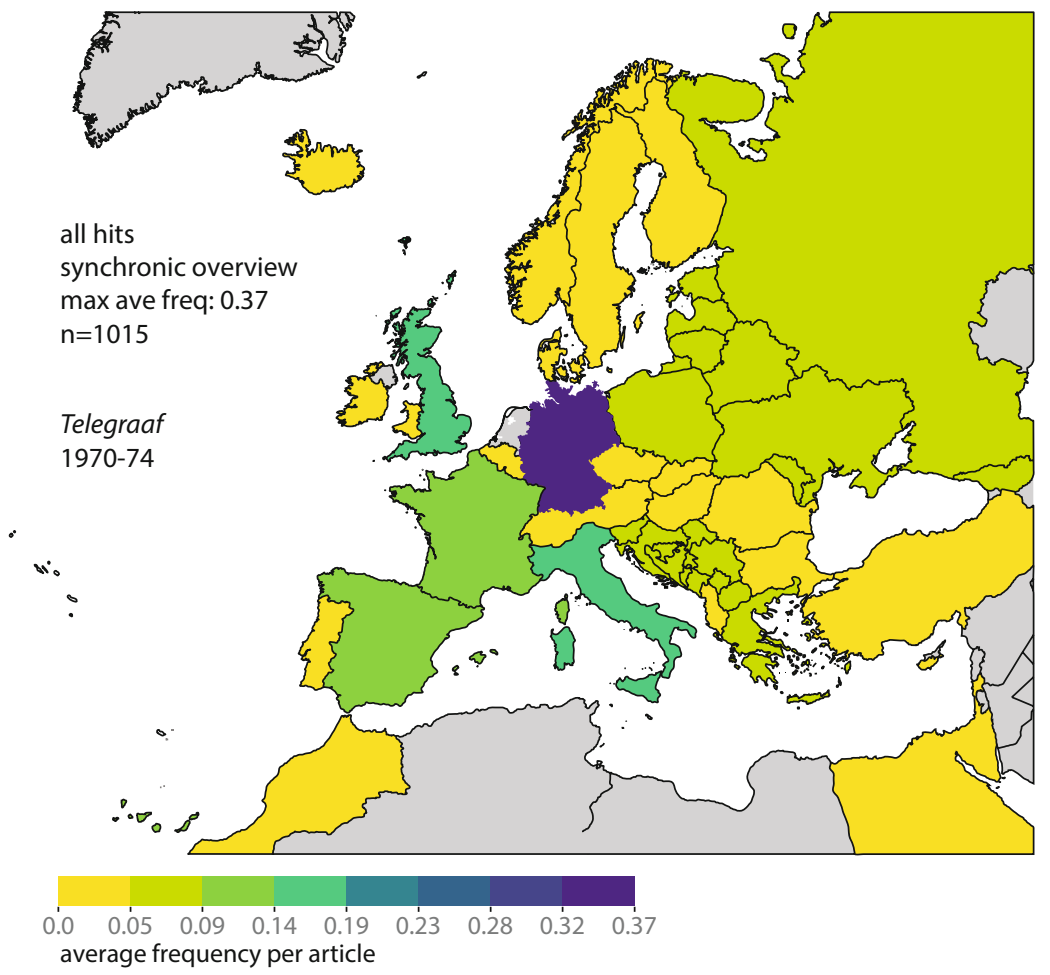

Figure 4.3 Nationalities in football: Map of Europe displaying average relative frequency of articles in De Telegraaf (1970-4) mentioning 'Europe' in combination with nationalities. Most historical countries like the USSR and Yugoslavia have been reconstructed (although twenty-firstcentury boundaries show through). Germany has been taken as a whole; the United Kingdom has been broken down into its constituent parts. Frequencies refer to all (rather than unique) hits per article and they are compared across space within the given period (i.e. synchronically rather than diachronically). Made in Python Basemap and Matplotlib.

\section{Conclusion}

I have claimed that a Self, such as a national Self, can be examined as a structured entity, a cultural matrix or collective mentality that endures over a longer period of time. Using a digital humanities approach allows for a more objective determination of the content of mentalities by reproducibly counting iterations in the media, thus avoiding the notion of 
'identity'. This notion hinges, first, on the selective choice of subjective appraisals made by particular historical actors and, second, on the no less selective choice of theories that tend to privilege fragmentation and temporality over stability and (semi-)permanence. Looking at the Self as a mentality in its own right is a more productive approach to the history of subjectivities than examining the Self as a fleeting construction based on the serial stereotyping of Others.

It is as striking as it is telling that a systematic analysis of tens of thousands of sports articles mentioning both 'Europe' and 'football' does not, in fact, reveal much about Europe. The competitive Europe that manifested itself in twentieth-century Dutch newspapers was very much a thin description, based mostly on the iterative mention of football-playing nationalities. From the point of view of the European theme 'united in diversity', the most significant thing to become part of the twentieth-century Dutch collective mentality was a spatial frame of reference that excluded substantial parts of the European Union as it would become with expansion in 2004. The geographical reach of the continent was quite severely circumscribed; Europe as part of the Dutch mentality turned out to be mostly Western, with a clear accent on the northern part of the continent. At the same time, the conception of Europe showed evident asymmetries: the cartographical status of Germany is a case in point. It is this relatively limited, asymmetrical vision of Europe that was integrated into the collective mentality of the Dutch. Such a mentality is structural; it is, therefore, not malleable or easily pliable, certainly not in the hands of intellectuals and politicians, however well-meaning their intentions are. 'Europe' as part of a tough, robust mentality rather than an identity has more purchase in explanations of recent events, ranging from Grexit to Brexit, than narratives that naively emphasize the enduring nature of a European civilization, or just as naively assume that Europe is a transient, constructed subjectivity that is as easily made as it is unmade.

\section{Notes}

1. 'Full Frontal with Samantha Bee' (Season 1, episode 17, broadcast 27 June 2016: 'Oh Shit, Brexit'). See https://www.youtube.com/watch?v=9r5P1z4OWWo [accessed 4 April 2017].

2. Patrick Chamorel, 'Anti-Europeanism and Euroskepticism in the United States', in Thomas L. Ilgen, ed., Hard Power, Soft Power and the Future of Transatlantic Relations. London and New York: Routledge, 2006, 163-92.

3. For cultural-historical theory, see Simon Gunn, History and Cultural Theory. Harlow: Pearson Longman, 2006, 131-55; Anna Green, Cultural History. Basingstoke: Palgrave Macmillan, 2008; Achim Landwehr and Stefanie Stockhorst, Einführung in die Europäische Kulturgeschichte. Paderborn: Boehlau, 2004, 193-214. 
4. Hans-Georg Gadamer, cited in K. Mueller-Vollmer, ed., The Hermeneutic Reader: Texts of the German Tradition from the Enlightenment to the Present. New York: Continuum, 272. See Albrecht Classen, 'European Views of the Other', in Maryanne Cline Horowitz, ed., New Dictionary of the History of Ideas IV. New York: Scribner, 2005, 1691-8 (esp. 1692).

5. Valerie Kennedy, Edward Said: A Critical Introduction. Cambridge: Polity Press, 2000; Daniel Martin Varisco, Reading Orientalism: Said and the Unsaid. Seattle and London: University of Washington Press, 2007.

6. See David Oswell, Culture and Society: An Introduction to Cultural Studies. London: Sage, 2000, especially chapter 5: 'Identity: Between Subject and Object', 102-30.

7. Turner, of course, used the term 'sectionalism': see Frederick J. Turner, The Significance of the Sections in American History. New York: Henry Holt, 1932.

8. http://ec.europa.eu/COMMFrontOffice/publicopinion/index.cfm.

9. A. Burguière, The Annales School: An Intellectual History. Ithaca, NY: Cornell University Press, 2009; Peter Burke, The French Historical Revolution: The Annales School 1929-2014. Cambridge: Polity Press, 2015.

10. Clifford Geertz, 'Thick Description: Toward an Interpretive Theory of History', in Michael Martin and Lee C. McIntyre, eds, Readings in the Philosophy of Social Science. Cambridge, MA and London: MIT Press, 1994, 214-32.

11. Benedict Anderson, Imagined Communities: Reflections on the Origin and Spread of Nationalism. London: Verso, 1991.

12. J. van Eijnatten, 'Beyond Diversity: The Steady State of Reference Cultures', in International Journal for History, Culture and Modernity, 3 (2015): 1-8. DOI: http://doi.org/10.18352/ hcm.495.

13. Introductions to digital humanities include Melissa Terras, Julianne Nyhan and Edward Vanhoutte, eds, Defining Digital Humanities: A Reader. Farnham: Ashgate, 2013; Susan Schreibman, Ray Siemens and John Unsworth, eds, A New Companion to Digital Humanities. Chichester: Wiley Blackwell, 2015.

14. Anthony Pagden, The Idea of Europe: From Antiquity to the European Union. Cambridge: Cambridge University Press, 2002; Heikki Mikkeli, Europe as an Idea and an Identity. Basingstoke: Macmillan, 1997.

15. Joris van Eijnatten, 'The Beauties of a Continent: Historical Images of Europe in Smaller and Bigger Data', in Marjet Derks, Martijn Eickhoff, Remco Ensel and Floris Meens, eds, What's Left Behind: The Lieux de Mémoire of Europe Beyond Europe. Nijmegen: Vantilt, 2015, 190-8.

16. Mariëtte Wolf, Het geheim van De Telegraaf: Geschiedenis van een krant. Amsterdam: Boom, 2009.

17. De Telegraaf, 23 December 1978: 'Het Hollands voetbal verdient een groot compliment. Hollanders voetballen typisch Europees, maar ze brengen bij vlagen een Zuidamerikaanse 'touch' in hun spel. Dat maakt ze zo onberekenbaar. Het voetbal bij jullie moet goed georganiseerd zijn. Anders kom je nooit zo ver'.

18. Nederlands dagblad: gereformeerd gezinsblad (21 June 1990); Het vrije volk: democratischsocialistisch dagblad (3 December 1988); De tijd: dagblad voor Nederland (22 January 1970). 
Part II

Globalizing Peripheries 

5

\section{From the Baltic to the Pacific: Trade, Shipping and Exploration on the Shores of the Russian Empire}

Michael North

\section{Introduction}

For a long time, imperial and Soviet historians painted the Russian Empire as a homogenous unified nation state. They overlooked the fact that Russia was a complex conglomeration of peoples, religions, languages and ethnicities. Moreover, this Empire was made up of many heterogeneous peripheries, which pointed in different geographical directions. Its history exemplifies how asymmetrical encounters create imperial space. Within the process of negotiating these relations, a frequently shifting imperial core was not always identical with its political capital. ${ }^{1}$

This chapter examines how the Russian Empire created economic peripheries in outposts on the Baltic and the Pacific. Behind this attempt was the idea to build a Russian commercial network across the Northern Pacific to provide its settlements in the Far East and in Alaska with provisions, and to link them with Spanish California and Manila, as well as with the Chinese port of Canton (Guangzhou). For this purpose, Russia used ships such as the Nadezhda ('Hope') and the Rurik to send Baltic German naval officers from the Baltic to the Pacific. Although their hopes of establishing a Russian trading empire and creating a 'Russian Pacific' failed, these explorations, and especially the travel journals by Adam Johann von Krusenstern and Otto von Kotzebue, had a long-lasting impact on public debates at home and on the European imagination. In the case of the Baltic provinces, the chapter demonstrates how 
a European periphery was transformed into a core region of the Russian Empire. Taken together these two case studies show that peripheries do not simply emerge, but that they are the result of sophisticated economic strategies and imperial policies, and that they rarely stay the same over longer periods of time. Furthermore, the example of Russian economic expansion in the East forces us to rethink our Eurocentric map of the world: the focus on Russia's imperial periphery places the Pacific at the centre of its system of trade.

\section{Russian expansion in the seventeenth and eighteenth centuries}

A brief outline of Russian expansion in the early modern period will set the scene for the subsequent analysis of the Empire's new configuration of its various centres and peripheries. Following the consolidation of the Muscovite state in the fifteenth century, by the sixteenth century Russia stretched from the White Sea in the north and Pskov in the west, to the river Volga in the east. In 1552-6 Ivan IV invaded and defeated the Volga khanates of Kazan and Astrakhan, expanding the Muscovite state south to the Caspian Sea. This provided the way for further expansion into Siberia, which followed, on behalf of the rich merchant family of Stroganov, over the following decades. The leading motive behind this expansion was the race for furs, which were demanded as tribute (yasak) from the various local peoples. Cities such as Tobolsk (1587), Tomsk (1604) and Okhotsk (1648) were founded as centres of the fur trade, in order to satisfy Russian and Chinese demand. The attempt, however, to get a stable foothold in Livonia and on the Baltic Sea failed as a result of Danish, Swedish and Polish resistance, which excluded Russia from expanding its influence into the Baltic area until 1710.

Russia's maritime ambition started with Peter the Great (16821725), who in 1695-6 led a campaign to conquer the Ottoman fortress of Azov to gain access to the Black Sea. Even more important to him was access to the Baltic Sea, however. After taking Ingria from the Swedes, he founded a new capital at the mouth of the Neva River in 1703. His intention was to create an 'imperial Amsterdam', which was to be better suited to international trade than Archangelsk on the White Sea, which was frequently blocked by ice. Although back in the early 1600s, on the land that was to become St Petersburg, the Swedes had built a small settlement called Nyen, Peter planned a new city, which, like Novgorod before it, 
would become the centre of all Western trade with Russia. By the end of the eighteenth century, St Petersburg, with a population of 220,000, had developed into the largest city on the Baltic Sea, outgrowing all other trading centres, including Copenhagen $(101,000)$, Stockholm $(76,000)$, Königsberg $(55,000)$, Danzig $(40,000)$ and Riga $(30,000)$.

Thanks to Russia's success in the Great Northern War, Sweden, in 1721, signed the Treaty of Nystad and ceded the provinces of Livonia, Estonia and Ingria to Russia, along with a portion of Karelia. These territories included the cities and fortresses of Riga, Dünamünde, Pernau, Reval, Dorpat, Narva, Viborg and Kexholm, along with the islands of Ösel and Dagö. In return, Russia ceded Finland to Sweden, and paid war reparations of two million riksdaler. In addition, Swedish merchants were permitted to continue buying grain in Baltic ports up to a value of 50,000 rubles, without paying duty. ${ }^{2}$

Having gained a stable foothold in the former Swedish provinces of the Baltic, Russia transformed these into its western provinces. This in turn led to the 'Europeanization of Russia's imperial image', modelled after the European colonial empires. ${ }^{3}$ Russia also expanded its maritime interest in the south and the Far East. Although Peter's campaign against Azov had been successful, the Turks prevented Russian ships from sailing out of Azov, and Russian goods from being shipped across the Black Sea to Constantinople. Only Catherine II, the Great (1762-96), was able to conquer the northern Black Sea coast. To achieve this, she sent the Russian Baltic fleet around Gibraltar in 1770. It blocked the Dardanelles, and reached Constantinople from the west. Although the Russian campaign was only partially successful, it ended the Turkish monopoly on shipping in the Straits and in the Black Sea. The Treaty of Kuchuk-Kainardji between Turkey and Russia (1774) declared 'free and unimpeded navigation for the merchant ships belonging to the two Contracting Powers'. ${ }^{4}$ Furthermore, this sparsely populated territory (the so-called 'New Russia') attracted settlers from Russia and the Holy Roman Empire; and in 1794 the city of Odessa was founded as a further major Russian harbour in the Black Sea.

\section{Russian ambitions in the Far East}

In the Far East, where Russian trade with China had been carried out over land and via the great rivers Ob (via Tobolsk) and Yenisei (Irkutsk), the Russian expansion into the Pacific provided new opportunities. It 
had occurred in several steps. After the initial foundation of a settlement for the fur trade at Okhotsk, several further expeditions led by the Danish captain Vitus Bering followed. During these expeditions, the Kamchatka Peninsula and the Russian Pacific coast were explored, and the Aleutian Islands and Alaska were discovered. From the 1750s onwards, Russian merchants sent fur hunters into these areas to catch seals and sea otters. In Kodiak and Sitka (Alaska) further settlements were founded, and in 1799 Emperor Paul chartered a Russian-American Company to develop trade. The idea behind these initiatives was that the North Pacific's endless supplies of fur would lead to new trade with China and Japan. ${ }^{5}$ Russian economic interests, as well as concerns about a growing British presence in the North Pacific after Captain Cook's third voyage, stimulated further expeditions. These were led by the Baltic German officers Adam Johann von Krusenstern and Otto von Kotzebue, who had served in the Russian navy - and in the case of Krusenstern also in the Royal Navy.

The first Russian circumnavigation was launched from St Petersburg in 1803 and aimed at establishing a trade contact with Japan. Behind this attempt was the idea to build a Russian commercial network across the North Pacific in order to provide the settlements in the Far East and Alaska with provisions, and to link them with Spanish California and Manila as well as with the Chinese port of Canton (Guangzhou).

On 7 August 1803 the Nadezhda and Neva, under the command of Krusenstern and Yuri F. Lisiansky, left Kronstadt and sailed across the Baltic Sea and the Atlantic Ocean, calling at the Canary Islands and Santa Catarina in Brazil. After passing Cape Horn the ships crossed the Pacific with stops at the Marquesas and Hawaiian islands. From there the Neva headed to Alaska, the Nadezhda to Kamchatka. The Nadezhda left Kamchatka for Japan on 7 September 1804. Besides Krusenstern, the delegation included Count Nikolay Rezanov, who was supposed to become the first Russian ambassador in Japan and was going to ask for an opening of trade relations between Japan and Russia. Although the Russians brought gifts, and returned Japanese sailors who had been shipwrecked on Russian Pacific shores, the mission proved to be a disaster. During their stay in Nagasaki, the Russians provoked serious tensions over ritual and etiquette, refusing to stand up in front of Japanese officials or to store their hand weapons, as shogunal regulations required. Therefore they were denied what they sought: the opening of trade with Japan. In G. H. von Langdorff's Journey Around the World, Captain Krusenstern describes his own and Rezanov's frustrations. Moreover, they expressed 
their disdain for the culturally more attuned Dutchmen, who were bowing and scraping for the Japanese in local fashion. ${ }^{6}$

While the mission itself was a failure, when Krusenstern and Rezanov returned to the Kuril Islands and met Japanese ships, the Japanese sold them provisions in exchange for 'old clothes and buttons'. Captain Krusenstern found these transactions perplexing, as either the buttons must have been 'of particular value to them, or herrings none at all, for they exchanged from fifty to a hundred of them dried, finer than I ever met them, for an old brass button'. Furthermore, 'the Japanese bartered pipes, lacquered dishes, and particularly books of obscene pictures'?

For these reasons Krusenstern and Rezanov continued to believe that trade with Japan remained an option, leading Rezanov to draft a plan for a Russian-Pacific presence in Sitka. The major aim was to solve the problems of food supplies for the Russian-American colonies. Several options were discussed: one was to establish trade with Spanish California; another to force Japan to trade, especially to provide rice for Russian settlers. Further options discussed were trade with Manila or the establishment of a Russian colony in Northern California, based on the agriculture of indigenous people. A last option was to make contact with Boston traders, who frequently called on the Pacific coast. Having returned, via the Indian Ocean, to Russia on 22 July 1806, only one option of Rezanov's ambitious plan proved viable: the establishment of a colony in Northern California, where in 1811 the Russian-American Company founded Fort Ross, located north of the bay.

Despite the various difficulties outlined above, the scientific outcome of the Nadezdha expedition was remarkable. Krusenstern published a travel report in German (Reise um die Welt) and later in English (Voyage Round the World), as well as an atlas with 104 maps and engraved paintings of the Pacific. ${ }^{8}$ The public interest in the first Russian circumnavigation triggered further Russian explorations into the Pacific, of which the expedition of the Rurik, led by Otto von Kotzebue, stands out. Kotzebue had been a member of the Nadezhda crew, and in 1814 received his own command from Count Nikolay Rumyantsev, a St Petersburg statesman and philanthropist, who financed the construction and voyages of the Rurik. Their aim was to discover for Russia the Northwest Passage, to acquire new knowledge of the Pacific and its inhabitants, and to assemble objects of natural history for his private collection. This explains why the botanist Adelbert von Chamisso and the artist Louis Choris were recruited with the specific aim of bringing back objects, descriptions and paintings. The expedition of the Rurik (1815-18) resulted in the collection of rich materials and ample new knowledge. More than 400 islands 
were recorded and put on the Pacific map. Furthermore, Chamisso produced two reports: Remarks and Opinions of the Naturalist of the Expedition and A Voyage around the World with the Romanzov Exploring Expedition, the latter including descriptions of his encounters with native peoples. ${ }^{9}$ Especially his encounter with Kadu from the Ratak Island in the South Sea, who for nine months travelled on board of the Rurik, strongly impressed Chamisso and his fellow crew members: ${ }^{10}$

He was not unteachable, not without intellectual curiosity. He seemed to understand well what we endeavoured to make him understand about the shape of the earth and our nautical arts, but he had no tenacity, became exhausted through the effort, and returned to his songs to avoid it. He took some pains to learn writing, the secret of which he had comprehended, but he as without talent for this difficult attempt. What he was told with the intention of encouraging him might have completely deprived him of courage. He suspended his study, took it up again, and finally put it aside entirely.

He seemed to grasp with an open mind everything that we told him about the social order in Europe, of our customs, morals, arts. But he was most receptive for the peaceful adventure purpose of our journey, with which he connected the intention of telling newly discovered peoples what was good and useful for them, and by this he understood chiefly what goes toward sustenance; but he also recognised that our superiority rested on our greater knowledge, and he honoured and served our research efforts as much as possible, even when it would have seemed very idle to many a more educated person among us. ${ }^{11}$

Although the quest for political and economic domination in the Pacific failed, via the fur trade Russia and its settlements were closely linked to Spanish California and China, and thus to the emerging Pacific economy, in which British and American ships carried the lion's share of commodity exchanges. Initially, the fur trade was centred on Okhotsk, from where Russian traders took the pelts inland to Kiakhta, thus satisfying Chinese luxury demand. Since Chinese consumers preferred fine sea otter pelts, their hunting, carried out by indigenous Aleut and Kodiak hunters, assumed a global dimension. When the sea otter population in the North Pacific declined, sea otters in California became the target of the Russian-American Company. Since Native Americans lacked the relevant skills, the company used American ships to bring Aleut and Kodiak hunters, together with their weapons and families, to California. While 
the men hunted, Aleut woman and children skinned and cooked the otters. American ships then took the pelts to Canton. On occasions also the labour force was shipped back to Kodiak and Sitka.

Despite these efforts, it remained difficult to sustain Russian interests in the area, and in 1823 Kotzebue was sent once again on an expedition into the North Pacific:

In the month of March of the year 1823, I was appointed by his Imperial Majesty Alexander the First, of glorious memory, to the command of a ship, at that time unfinished, but named the Predpriatie (the Enterprise). She had been at first destined for a voyage purely scientific, but circumstances having occurred which rendered it necessary to change the object of the expedition, I was ordered to take in at Kronstadt a cargo to Kamschatka, and to sail from the latter place to the northwest coast of America, in order to protect the Russian-American Company from the smuggling carried on there by foreign traders. On this situation my ship was to remain for one year, and then, being relieved by another, to return to Kronstadt. ${ }^{12}$

\section{Russia's Pacific provinces in the nineteenth century}

The nineteenth-century Russian presence in the Pacific was still characterized by the problem of long distances between the settlements on the western and the eastern shores, and the difficulty in providing them with provisions. Furthermore, competition from British and North American ships, from whalers, traders and fur hunters also proved difficult. By the 1830s, only 800 Russians had settled in Alaska and the population subsequently declined, due to the difficulties with provisions and the exhaustion of the fur supplies on which the Russian-American Company's survival depended. After the near-extinction of sea otters, the fur hunt moved further south, concentrating on seals, which were available all over the Pacific. British, French, Spanish and American ships dominated the seal hunt, especially on the Juan Fernández Islands off the coast of Chile. ${ }^{13}$ Finally, in 1841 the Russian-American Company sold Fort Ross to the Swiss landowner and entrepreneur John Sutter.

The western coast of the Pacific, i.e. the Russian Pacific Coast, moved into the Empire's focus when, in 1849, a Russian ship rediscovered the mouth of the river Amur. Although in the Treaty of Nerchinsk 
(1689) Russia had ceded this region to China, the Russians reoccupied it in 1854, and two years later declared it a free trade zone. They founded the fortress Khabarovsk and after the emancipation of serfs in 1861 promoted migration to the area. In the unequal treaties of Aigun (1858) and Beijing (1860), China had to accept first the transfer of $600,000 \mathrm{~km}^{2}$ from the Stanovoy Mountains to the Amur River, and two years later the Russian occupation of the coastal territory south of the Amur down to the Korean border. Here, in 1860, Russia established a new military and naval base, giving it the name Vladivostok (Ruler of the East). Russian settlement in the area remained slow, and only increased after the opening of the Trans-Siberian railway at the end of the century. Nevertheless, peasants, small traders and seasonal workers migrated from Korea and China into the new Russian territories. Vladivostok became the basis for Russian expansion into Manchuria, where Russia claimed a protectorate over its northern part and established two new ice-free harbours at Port Arthur and Dairen. ${ }^{14}$

This successful expansion on the Pacific Coast changed the vantage point with respect to the American possessions. ${ }^{15}$ While Russia consolidated its transcontinental European-Asian Empire, the maritime American periphery became finally obsolete, especially since the driving motive of the eighteenth-century expansion, the fur hunt, no longer yielded sufficient profits. As a consequence, in 1867, after ten years of negotiations, Russia sold Alaska for \$7.2 million to the United States. The sale to the United States, rather than Britain, also fulfilled Russia's aim to undermine British power in the Pacific.

\section{Ethnic nationalism and Russification in the Baltic provinces}

In the Baltic provinces an intensified integration into the Russian Empire and the emergence of national movements among Estonians and Latvians took place. Administrative ties were strengthened under Catherine I (r. 1725-7). A law commission was set up to advance legal unification and the administrative reach of the tsarist Empire. Representatives of the nobility and the cities took part in this effort, and together with the Finnish representatives and those of the former Polish-Lithuanian territories in Ukraine, they defended the rights of the provinces against those of the Russian Empire. After Russia's successes in the wars against the Ottoman Empire, Catherine II, the Great (r. 1762-96), intensified her reform efforts, and in 1775 she introduced a new provincial ordinance. Initially 
this came into force in Russia alone, but in 1783 it was extended into the Baltic provinces and, similar to the effects of introducing the Russian head tax, bound these provinces closer to St Petersburg. Stuck in provincial narrow-mindedness, the nobility was initially pleased that it continued to be exempt from taxation, and that taxes were largely borne by the Estonian and Latvian population. Also, the allodification of the manorial farms (which became actual property) was welcomed by the nobility. The cities, however, resisted the elimination of their privileges that followed the Russian municipal ordinances of 1785. Meanwhile, the ordinances led to freedom of trade and, for example in Riga, laid the ground for the industrialization of the following century. Although Paul I (r. 1796-1801) restored the old city and provincial constitutions when he was enthroned in 1796, he introduced the Russian military recruitment law in the provinces, which meant long-term service in the Russian army for any young man caught up in its net. ${ }^{16}$

Over the following century the position of the Baltic-German ruling class was increasingly challenged by rising Latvian and Estonian nationalism. Already around 1800, pastors and physicians promoted a new image of the Estonians and demanded improvements to their economic and social situation, especially in the form of agrarian reforms. 'Estophiles' - culturally engaged Baltic Germans and Estonians who had risen into the middle class - joined them. Their writings would culminate in the national movement of the second half of the century, while also serving as a cultural mediator between the urban middle class and the Estonian peasantry. A Latvian literary society (Latviešu Literāriskā Biedrība) was formed in 1824, largely by Couronian pastors, while in Dorpat the Estonian physician Friedrich Robert Faehlmann (1798-1850) founded the Learned Estonian Society (Õpetatud Eesti Selts).

The main political concern of Estonians and Latvians was to secure equality with Baltic Germans, both in education and before the law. The liberalized pass ordinance of 1863, which granted the peasantry freedom of movement, brought about greater mobility, especially in southern Estonia. The effect of political publications such as Perno Postimees (Perno Postman), the first Estonian newspaper, published in Pernau in 1857, or the Latvian Majjas Viesis (House Visitor) in 1856, should not be underestimated. ${ }^{17}$ Song festivals became a regular fixture celebrating national sentiment in Estonia from 1869 and in Livonia from 1873 onwards. ${ }^{18}$ Estonian and Latvian developed into modern cultural languages by precisely this literary process. Voluntary associations also reflected these developing national cultures. Farmers, volunteer fire 
brigades, mutual aid organizations, teetotallers and choristers formed societies at the local level, which soon developed into larger associations with regional and even national members.

In the Baltic provinces, pastors influenced by Enlightenment ideas, along with Estophiles, prepared the groundwork for agrarian reforms. Although the peasant ordinances of 1802-4 had validated the laws tying the peasantry to the soil, new laws promulgated in 1816, in Estonia, and in 1819, in Livonia, freed the serfs. The manorial landowners, however, continued to own the land, which forced the now independent peasants to sign rental agreements to farm that land. As elsewhere in Europe, crop failures, starvation and revolts led to new agrarian laws in Livonia (1849) and Estonia (1856), which allowed the peasants to acquire land and regulate its acquisition with the help of public credits. Moreover, land they used to farm was transferred into their property in exchange for ceding one-sixth to the landowners. The previously dominant form of natural rent or labour eventually gave way to financial operations. This resulted in economically viable and productive units that could compete on the open market with the manorial farms. This was especially successful with crops such as linseed and for cattle and horse breeding. Vodka distilling, to meet demand in Russia, also proved extremely profitable. ${ }^{19}$

In the Russian Baltic provinces, the expansion of the railway network served as a powerful impetus to trade and transport because port cities could now be connected both with each other and with the hinterland. A direct connection between Riga and Mitau was opened in 1868. In 1870, this was followed by the line from Baltischport (Paldinski) to St Petersburg by way of Reval and Narva. The construction of railway lines worked in favour of the port cities through which they ran. Once Riga was connected with the hinterlands of Ukraine and southern Russia, it suddenly became a major player in grain exports. The population almost tripled between $1871(103,000)$ and $1897(282,000)$, reaching 520,000 in 1913. Riga recruited its population primarily from the countryside. Libau (Liepāja) was also able to improve its position by exploiting its railroad connection, while Reval grew into the second most important Russian port for imports after St Petersburg. Industrialization kept up with urbanization. ${ }^{20}$

With the population increase, the ethnic composition of these cities also changed fundamentally. In Riga Latvians replaced Germans as the dominant nationality during this period, while the Russian element remained approximately stable. A glance at the structure of the labour force demonstrates another transformation. While Germans, despite their general decrease in the population as a whole, continued to be represented in the bureaucracy and in the free professions, the proportion 
of Germans working as artisans, merchants and in the service sector decreased. Latvians became more prominent in these sectors and in industry generally. Russians were equally active in administration, trade, industry, the manual trades and other services. The Jewish population became more prominent in the free professions and as merchants.

Out in the countryside, by contrast, the changes were less significant, because during the nineteenth century Estonia was already 90 per cent Estonian, while Latvians were the predominant population group in Livonia (about 80 per cent). The transformation was much more dramatic in the cities, especially in Riga, where Germans felt caught in a pincer by the progressive Russification of the region, by the Latvian nationalist movement, and as a consequence of the industrial labour movement (social democracy). For Latvians social mobility in the industrial society fostered the emergence of a Latvian national movement. Latvian agitation was directed first against the Germans and then the Russians. Both Latvians and Russians cultivated anti-Semitic stereotypes, which in turn found ready acceptance among the Germans. ${ }^{21}$

Thus, the intensification of Russian rule strengthened the connections between the Baltic provinces and St Petersburg, as well as the role of Russian culture in the area. This meant at the same time a redefinition of the region's sense of belonging, from forming the periphery of a European Empire to becoming a core area of a (new) Russian Empire, alienating at the same time many of its (non-Russian) people from tsarist rule. ${ }^{22}$ This process would culminate in the anti-German revolts during the Revolution of 1905, as well as (in 1918) the success of the Baltic independence movement. ${ }^{23}$

\section{Conclusion}

This chapter elucidated different economic and political developments in two distant peripheries of the Russian Empire. Their role and economic function changed over time. Fuelled by the fur hunt and respective Chinese demand, around 1800 the Russian Pacific area formed part of a global Pacific economy; but its role shifted during the nineteenth century, due to the exhaustion of fur supplies and growing international commercial and naval competition. This led to the Russian retreat from the American continent and the concentration of imperial policies on the Russian land Empire, although even then its eastern outposts were expanded and militarily consolidated. 
While the Russian Far East remained an imperial periphery, the Baltic provinces lost their peripheral status. Through the railway network, integration of the administration and Russification, they were economically, institutionally and culturally linked to St Petersburg and came to constitute the core region of the modern Russian Empire. Furthermore, since the Baltic Sea was crucial for Russian shipping to all parts of the world, the Empire's western fringe came to play the role of a middleman and mediator for Russia's relationship with Western Europe and the wider world.

Despite the consolidation of its imperial policies, however, the Empire remained vulnerable. The Russian navy continued to operate in three different arenas, which were characterized by enormous distances between them. Since its Black Sea fleet was more or less geographically isolated, when Russia wanted to increase its naval presence in the Mediterranean it had to dispatch ships from its Baltic fleet. Furthermore, Russia had no naval bases between Libau on the Baltic and Port Arthur on the Pacific. This became obvious when Japan, as the newly emerging Pacific power, tried to stop the Russian expansion on the Russian Pacific coast and besieged Port Arthur. Russia sent its Baltic fleet, which had been based at Libau, the long way around the Cape of Good Hope to the Pacific, only to be defeated by Japan in the Battle of Tsushima in May 1905. ${ }^{24}$ The effects threw Russia into deep turmoil and marked the rise of a new empire in a different region of the world.

The two case studies show how imperial peripheries are formed, and how their function changes due to global economic processes, but also how a European periphery became the core of an empire that over the centuries had changed its outlook on the world. Within the context of this collection of essays, the chapter demonstrates that core and periphery, and the spatial hierarchies that regulate the relationship between them, in no way represent absolute categories.

\section{Notes}

1. Francisco Martínez, On the Peripheral Character of Russia, in e-cadernos ces, 19 (2013). Online since 1 June 2013, accessed 30 September 2016. URL: http://eces.revues. org/1562; DOI: 10.4000/eces.1562.

2. Robert I. Frost, The Northern Wars: War, State and Society in Northeastern Europe, 1558-1721. Harlow: Longman, 2000, 294-6.

3. Mark Bassin, 'Geographies of Imperial Identity', in Dominic Lieven, ed., The Cambridge History of Russia, volume II: Imperial Russia, 1689-1917. Cambridge: Cambridge University Press, 2006, 45-63, quotation from p. 46.

4. James T. Shotwell and Francis Deák, Turkey at the Straits: A Short History. New York: Macmillan, 1971, 1-31, quotation from p. 21. 
5. Ryan Tucker Jones, Empire of Extinction: Russians and the North Pacific's Strange Beasts of the Sea, 1741-1867. Oxford and New York: Oxford University Press, 2014, 102-36.

6. G. H. von Langsdorff, Bemerkungen auf einer Reise um die Welt in den Jahren 1803 bis 1807. Frankfurt am Main, 1812. 'How much it is regretted that an enlightened European nation, owing its political existence to a love of freedom, and which has acquired celebrity by great action, should so far debase itself from a desire of gains to attend with submission and devotion to the hateful commands of a set of slaves.' Leonard Blussé, Visible Cities: Canton, Nagasaki, and Batavia and the Coming of the Americans. Cambridge, MA and London: Harvard University Press, 2008, 94; Donald Keene, The Japanese Discovery of Europe, 1720-1830, revised edition. Stanford, CA: Stanford University Press, 1969, 9.

7. Adam J. von Krusenstern, Reise um die Welt in den Jahren 1803-1806, 3 vols. St Petersburg, 1810-12; Adam J. von Krusenstern, Voyage Round the World in the Years 1803, 1804, 1805, and 1806, trans. Richard Belgravce Hoppner, 2 vols. London, 1813, 52. Adam J. von Krusenstern, Reise um die Welt in den Jahren 1803-1806 aufden Schiffen Nadeshda und Newa, vol. 3. Bremen: Atlas, 2009 [1814]. For this and the following I am indebted to Matthew P. Romaniello and his lecture 'Imperial Aspirations: Russian Maritime Commerce in the Early Nineteenth-Century Pacific' at the International Maritime History Congress in Perth, 2016.

8. Krusenstern, Reise um die Welt, 3 vols; Adam J. von Krusenstern, Atlas de l'océan Pacifique, 2 vols. St Petersburg, 1824-7.

9. Adelbert von Chamisso, 'Remarks and Opinions, of the Naturalist of the Expedition,' in Otto von Kotzebue, A Voyage of Discovery: Into the South Sea and Beering's Straits for the Purpose of Exploring a North-East Passage, Undertaken in the Years 1815-1818, vol. 3, 168. London, 1821; Adelbert von Chamisso, A Voyage Around the World with the Romanzov Expedition in the Years 1815-1818 in the Brig Rurik, Captain Otto von Kotzebue, translated and edited by Henry Kratz. Honolulu: University of Hawaii Press, 1986; David Igler, The Great Ocean: Pacific Worlds from Captain Cook to the Gold Rush. Oxford: Oxford University Press, 2013.

10. Chamisso, A Voyage around the World, 263-83. For a broader view on the encounter between the Pacific islanders and the Europeans, especially Kotzebue and Chamisso and the construction of cultural knowledge, see Harry Liebersohn, The Traveler's World: Europe to the Pacific (Cambridge, MA and London: Harvard University Press, 2006).

11. Chamisso, A Voyage around the World, 266.

12. Otto von Kotzebue, A New Voyage Round the World in the Years 1823, 24, 25, and 26, vol. 1. London, 1830, 1-2.

13. David Igler, The Great Ocean: Pacific Worlds from Captain Cook to the Gold Rush. Oxford: Oxford University Press, 2013, 110-7.

14. Andreas Kappeler, The Russian Empire: A Multi-Ethnic History. London and New York: Routledge, 2013, 200-4.

15. Martina Winkler, Das Imperium und die Seeotter. Die Expansion Russlands in den nordpazifischen Raum, 1700-1867. Göttingen: Vandenhoeck \& Ruprecht, 2016, 297-309.

16. Gert von Pistohlkors, 'Die Ostseeprovinzen unter russischer Herrschaft (1710/95-1914)', in Gert von Pistohlkors, ed., Baltische Länder. Berlin: Siedler, 1994, 266-94. For this and the following see Michael North, The Baltic: A History. Cambridge, MA: Harvard University Press, 2015, 151-3 and 197-8.

17. Aleksander Loit, 'Die nationalen Bewegungen im Baltikum während des 19. Jahrhunderts in vergleichbarer Perspektive', in Aleksander Loit, ed., National Movements in the Baltic Countries during the 19th Century: The 7th Conference on Baltic Studies in Scandinavia, Stockholm, June 10-13, 1983. Stockholm: Almqvist \& Wiksell, 1985, 59-81.

18. Ea Jansen, 'On the Economic and Social Determination of the Estonian National Movement', in Aleksander Loit, ed., National Movements in the Baltic Countries during the 19th Century: The 7th Conference on Baltic Studies in Scandinavia, Stockholm, June 10-13, 1983. Stockholm: Almqvist \& Wiksell, 1985, 41-57.

19. Juhan Kahk, 'Die baltischen Agrarreformen des 19. Jahrhunderts in neuer historischer Perspektive', in Zeitschrift für Ostmitteleuropa-Forschung, 45 (1996), 544-55; Kersti Lust, 'Die Innovationsbereitschaft der livländischen Bauern und die Agrarreformen im 19. Jahrhundert', in Zeitschrift für Ostmitteleuropa-Forschung, 55 (2006), 510-25; North, The Baltic, 201-7.

20. Michael Garleff, Die baltischen Länder: Estland, Lettland, Litauen vom Mittelalter bis zur Gegenwart. Regensburg: Pustet, 2001, 75-7. 
21. Ulrike von Hirschhausen, 'Die Wahrnehmung des Wandels: Migration, soziale Mobilität und Mentalitäten in Riga, 1867-1914', in Zeitschrift für Ostmitteleuropa Forschung, 48 (1999), vol. 4, 475-523, especially 521-3; North, The Baltic, 210-11.

22. Bassin, Geographies of Imperial Identity, 45-63.

23. Andres Kasekamp, A History of the Baltic States. Basingstoke and New York: Palgrave Macmillan, 2010, ch. 4: 'The Long Nineteenth Century under Tsarist Rule (1795-1917)'.

24. Nikolai Afonin, 'The Navy in 1900: Imperialism, Technology and Class War', in Dominic Lieven (ed.), The Cambridge History of Russia, volume II: Imperial Russia, 1689-1917. Cambridge: Cambridge University Press, 2006, 575-89. 


\section{6}

\section{Republics of Knowledge: Interpreting the World from Latin America}

Nicola Miller

\section{Introduction}

In 1882 the celebrated poet, José Hernández, was offered a generous sum of money by the government of Buenos Aires Province to spend a year in Europe and Australia investigating how to boost agricultural productivity. As the author of the bestselling poem El gaucho Martín Fierro (1872 and 1879), which had rapidly acquired the status of a national epic, he potentially lent a certain credibility to a government initiative based on the assumption that best practice could only be imported from overseas. The story goes that officials took his acceptance so much for granted that they did not even trouble to consult him before announcing it to the newspapers. Hernández, however, at once refused to go: such a trip would be a complete waste of money, he insisted, because European ways of doing things were not applicable to Argentina. He could write a far better book, far more quickly, if he stayed right where he was. That was exactly what he did: after several months travelling around local estates, collecting information from the people who worked on them, he produced 330 pages of astute and comprehensive advice on all aspects of livestock raising, which became known as Instructions for the Rancher: A Complete Treatise on the Planning and Running of a Country Estate (1884). ${ }^{1}$ The government declined to purchase a single copy of it, and printed no fewer than 5,000 copies of a report produced, at great expense, by authors more in sympathy with the official view that Europe was the fount of all useful knowledge. ${ }^{2}$ But their extensive survey - all ten volumes of it - of the state of the art in Europe could not begin to compete 
with Hernández's short and serviceable libro criollo (creole book), which sold out in several editions and was still being reprinted in the 1940s.

This incident brings into sharp relief the two main themes of this chapter: i) the collectivity of knowledge; and ii) the recognition of knowledge.

On the collectivity of knowledge, the immediately striking point is that Hernández, as he acknowledged, was heavily reliant for information about best practice on the local experts he consulted. He had been born on a cattle ranch, where his father worked as a foreman, but his own career was in journalism, politics and literature. Less obviously, Instructions for the Rancher would probably not have made it into print at all had it not been for the courage of a certain bookseller-publisher, Carlos Casavalle, founder of the Imprenta y Librería de Mayo, whose distinguished reputation and networks of connections not only in Argentina but throughout South America gave him the invincibility necessary to incur government displeasure by publishing Hernández's book. Although much of the history of knowledge has consisted of studying the ideas of intellectual luminaries down the ages, the landscapes of knowledge were populated with a far wider range of people, all of whom made distinctive and often transformative contributions.

The extent to which such work was recognized (theme ii), either by contemporaries or historians, raises a series of questions about the status and legitimacy of knowledge. Categories of 'national' and 'foreign' knowledge coalesced at this specific conjuncture in Argentina, in the 1880s, when knowledge acquired locally succeeded in being recognized, by some if not all participants in public debates, as more valid than knowledge acquired elsewhere. Such developments point to the importance of thinking not only about how knowledge is produced or even how it is received but also how it acquires the necessary validation to be deemed worthy of being received. In turn, this relates to the importance of distinguishing between varying kinds of transnationalism: the near and the far; the experienced and the imagined. Hernández chose not to travel to Europe, but he did bring transnational experience to his treatise, having spent time in both Uruguay and Brazil. Moreover, his view that European agriculture was not applicable in South America was formed precisely through extensive reading about practices from Europe and elsewhere that had given him a comparative framework within which to operate. His rejection of one kind of transnationalism - going to Europe - for another - drawing comparisons closer to home - alerts us to the very different kinds of experience that can be covered by the umbrella term of transnationalism. Crossing continents is not the same as what I call localized transnationalism, that is, the multitude 
of connections, exchanges and comparisons that occurred between countries in Latin America, affecting most levels of society. There is more than one type of reference culture: the stimulus of common endeavour in similar conditions may be as great a source of inspiration and ideas as success achieved under very different conditions. Latin American countries looked to each other at least as much as any of them looked to Europe.

My themes will be illustrated with evidence from Latin America, the history of which offers an illuminating perspective on the history of knowledge, especially its role in modern nation-making. As the region of the world which rejected colonial rule during the Age of Revolution to found a second wave of modern republics (1808-26), Latin America was foundational to nineteenth-century debates about culture and politics. These new political communities all made a founding commitment to promoting knowledge and its circulation as central to the formation of modern societies. This commitment was particularly strong in the republics of Spanish America, where a rhetorical embrace of popular sovereignty was widespread, even if it was limited in practice, but it was also evident in the independent monarchy of the Empire of Brazil, which became a republic in 1889. These new countries were the ultimate test cases of nation-statehood, because they were constituted without any obvious differences of race, language or culture to differentiate one from another, as Benedict Anderson long ago pointed out. ${ }^{3}$ What was meant by a 'nation' was debated throughout Europe and the Americas for much of the nineteenth century; it was not so much the idea itself that was European as the 'one state, one culture' model that acquired the status of ideal type there. The differently constituted nation states of Latin America have been grappling for two centuries with questions that have more recently become troubling throughout the world. To what extent could modern political systems based on secular rights and freedoms coexist with widespread religiosity and racially based social hierarchies? How could the defence of sovereignty be combined with openness to investment and ideas from elsewhere? What role could the circulation of knowledge play in fostering collective identities and participatory democratic life, especially in the context of the modern global hierarchies of knowledge established during the nineteenth century? The varied histories of nation-making in Latin America, with their interconnected experiences of colonialism, independence and neo-colonialism, provide a unique body of evidence about all of these matters. These histories therefore open up a range of questions about the methodologies historians adopt and the categories they employ. 


\section{The collectivity of knowledge: Drawing teachers in Latin America}

In the spirit of recent scholarship in the history of science, ${ }^{4}$ I explore how the history of knowledge might look different if we saw beyond a minority of prominent figures. The celebrated individuals who tend to attract all the attention are of course worthy of interest, but so too are a host of other people: printers, editors, booksellers, librarians, trade unionists who ran night schools, compilers of almanacs and encyclopedias, lexicographers and bibliographers. In this chapter, I focus on drawing teachers, for two separate but, I argue, related reasons.

First, it is remarkable how many of the primary sources from the era of independence emphasized the pressing need to establish Schools of Drawing; the teaching of drawing was continually declared fundamental to popular education throughout the nineteenth century and into the early twentieth century. Second, national histories of art, which began to be written around the time of the centennials of independence and continued into the 1960s, routinely highlighted the autodidacticism of nineteenth-century artists, elaborating the idea of the exceptional individual springing untutored from his - or very occasionally her - native land to express the spirit of the people.

On the first point, the need to found schools of drawing, some impressive claims were made for the contribution of drawing to nation-making. Father Francisco Castañeda, who campaigned in 1815 for a school of drawing in Buenos Aires, saw drawing as the source of all possible desirable qualities and capacities for the first generation of the new republic. It was the one great skill that would deliver the people from ignorance and barbarity, instilling a work ethic, creating receptivity to republican laws and cultivating good taste. By learning to draw squares and circles the students would begin to understand geometry; by drawing hands and eyes they would apprehend anatomy; by drawing buildings and forts and ships they would learn the principles of civil, military and naval architecture; and by drawing machines they would appreciate mechanics and glean the principles of invention. Their drawing practice would give them a good knowledge of ancient history and mythology, of the Bible, and of modern history, and it would lead them naturally to other desirable accomplishments in music, dance and theatre. ${ }^{5}$ More measured voices declared drawing to be not only indispensable to the development of industry and the professions, but also a virtuous outlet for the physical energies of artisans. ${ }^{6}$ Many of the prominent figures of 
the time, across the continent, lent their support, financial and/or political, to the creation of drawing schools, not least the Liberator José de San Martín, who made drawing central to the curriculum of the school he founded in Mendoza.

Skills in drawing were indeed necessary to many of the activities of the new political communities that emerged from the wars of independence: the surveying of land and sea; map-making; natural history and science; architecture and town planning; civil and mechanical engineering; military strategy; and the dissemination of all kinds of information, including images of national heroes (and villains) and impressions of war. The art of the miniature, which flourished in the 1820s and 1830s, helped to make a divided social elite visible both to itself and to other sectors of the population, because the cameo portraits were published in the social columns of newssheets and on the death notices posted outside the local church or the town hall. ${ }^{7}$ Photography came early to Latin America and certainly played an important role in stimulating national consciousness from the 1840s onwards, but the camera lens could not so easily - or so cheaply - caricature or satirize as the cartoonist's swift pen; nor did the photograph lend itself so readily to the archetypes of nationalism. Thus, drawing was not an ornamental extra or something of interest only to art historians, but a skill that was fundamental to becoming modern societies and economies. Drawing teachers were highly prized and sought-after individuals, embedded in networks - both local and transnational - of engineers, geographers, scientists, artists, writers and politicians.

The best-known examples of drawing's contribution to national imaginings are the 'customs and costumes' collections of sketches and watercolours depicting the peoples and landscapes of various regions of a country. These were an international nineteenth-century publishing phenomenon, along with the records of scientific expeditions and the diaries of individual adventurers. Many of the early albums on Latin America were produced by artists visiting from Europe, who spent a few months following what quickly became well-established itineraries, and they were published in Europe for a well-heeled European audience. ${ }^{8}$ In most Latin American countries, however, there were local artists who became celebrated for their representations of scenes and people of the national territories, many of which were printed in cheap editions or on posters, pamphlets or flyers. It was these artists whose supposed autodidacticism was later made so much of by nationalists. 


\section{An example from Peru: who taught Pancho Fierro?}

Francisco Fierro (1807-79), usually known as Pancho, painted hundreds of watercolour vignettes of Lima and its people, which circulated widely both in Peru and beyond. They were used as illustrations for the emerging mid-nineteenth-century genre of urban guidebooks; they adorned the famous and popular books of stories, Peruvian Traditions (1872-1910), by Ricardo Palma, Peru's main nineteenth-century chronicler of social life. ${ }^{9}$ Fierro, who was Afro-Peruvian, has been described as 'the painter of the people' who spontaneously expressed 'Peruvian creole identity'. Such accounts acknowledged that he was highly daring and accomplished technically, yet still claimed that 'he never set foot in an academy', ${ }^{10}$ an apparent contradiction which has prompted several recent attempts to identify where and how he learned to draw and paint. Who taught Pancho Fierro? The detective challenge has yielded no conclusive documentary evidence so far, but these investigations have exposed as illusionary the romantic image of an inspired but isolated dabbler who unwittingly tapped into a latent essence of Peruvianness. ${ }^{11}$

In order to understand the sources of Pancho's methods, it helps to think about a wide range of factors on various scales: local, national and transnational. The immediate context was the emergence of modern drawing teaching in late eighteenth-century Peru, when there was a marked switch from religious imagery to historical and social subjects. That development, in turn, has to be understood in the context of a changing political and administrative order in colonial government, manifested in the Bourbon Reforms, especially from the 1760s under Charles III. The Spanish Crown took steps to preserve its monopoly on trade and to preclude the emergence of industrial competition from its overseas possessions, but the reforms had only limited success, which prompted some creoles, especially those who had worked in Spain, to start planning for industrialization in the Americas. Such initiatives were boosted by the spread of Enlightenment ideas, including the Spanish Enlightenment, and by the increasing visibility of science and the possibilities for scientific exploration and exchange - of which Humboldt's journeys through the Americas (1799-1804) were the most famous among many. ${ }^{12}$ By the early nineteenth century, i.e. before the imperative of republican citizenship, the conditions had been created for education to be made more widely available, and for it to be provided by the state instead of the reli-

gious orders. Changing local market conditions also have to be taken into account: the late eighteenth-century move away from the devotional art 
commissioned by the Church or by wealthy lay families was also made possible by a growing internal market for portrait painting.

The context for understanding Pancho Fierro's work also includes the history of Peru as a major centre of cultural production during the colonial period. The renowned Cusco school of art had enjoyed 250 years of influence on the plastic arts throughout South America. Growing up in Lima, Fierro would have had models of sophisticated religious painting and sculpture to observe all around him. Peru's distinguished artistic tradition also meant that it was an attractive destination for the masters of drawing who came with foreign scientific expeditions. One relevant example was Francisco Javier Cortés (1775-1841), from Quito, a highly skilled botanical artist, who had travelled with the naturalist José Celestino Mutis. He became Professor of Drawing at the School of Medicine in Lima and gave free evening classes open to all. It is likely, although it cannot be confirmed, that Fierro was in touch with Cortés, if not actually taught by him. ${ }^{13}$

During the early nineteenth century, as a result of all these converging factors, drawing evolved from being a means of designing or recording (as in the colonial term trazador, derived from the verb trazar, literally 'to trace') to being a means of imagining or interpreting by the dibujante (someone who draws, from dibujar, to draw).${ }^{14}$ Drawing, in a generic sense, was becoming a mode of apprehending the world, which in itself contributed to the conditions of possibility for new political communities.

With independence, new institutions were created to teach drawing; there was an influx of visitors, including itinerant artists from Europe; and international publishers began to export to Latin America, expanding the variety of images in circulation. Although Pancho Fierro supposedly 'lived and died in poverty, without fame or glory', there is evidence that he made a lot of money selling his watercolours to foreign visitors. ${ }^{15}$ All those contacts were part of the repertoire of knowledge that informed his creative practice; he sustained a successful career for five decades and clearly knew how to adapt and respond to market demands and how to fulfil the role expected of him. Investigations about who taught Pancho Fierro have also unearthed new international and transnational connections. The historian Natalia Majluf, who argues that the mythology of the popular artist both dehistoricizes culture and denies agency, searched customs records to find that there was a high volume of trade between Peru and China in the 1830s. She also found travel accounts indicating that images of Lima were sent to China, sold well there and were then re-exported, so 
Fierro probably saw these Chinese images of Peru, signs of which can be detected in his own work. ${ }^{16}$

Nationalist histories of art from the mid-twentieth century tended to divide artists into two categories: 'academic', i.e. divorced from their roots; and 'popular', i.e. authentic expressions of purely local experience. Fierro was often contrasted with Ignacio Merino, who was sent to Paris very young and lived in Peru for only 12 years (1838-50) before returning to Europe. His work has been dismissed by cultural nationalists as 'salon painting', ${ }^{17}$ but his works have been analysed by later historians as illustrating a whole range of critiques of the methods he had been taught in Paris. The academic/popular divide, like so many other binaries, paints over so many other possibilities.

One reason, then, why it is so important to ask about possible teachers is in order to differentiate history and myth in relation to autodidacticism. A claim that somebody was self-taught is a key for unlocking information about the opportunities a society offers to acquire cultural capital. Instead of thinking in terms of what is lacking - formal education - it is worth exploring what made it possible for certain individuals to learn informally. Was there a familial or other social context in which learning was valued? What other routes were available for gaining access to knowledge? There are many possibilities to consider, including bookshops, libraries, the informal circulation of printed matter, reading aloud from newspapers or other ephemeral materials, talks or lectures, contacts with more educated individuals prepared to act as guides and mentors, and opportunities to do a variety of jobs and to travel. Thus autodidacticism, which is portrayed as a celebration of individualism, actually reveals the significance of the social structures and networks - both local and transnational - that made the creative work of autodidacts possible.

Perhaps the greatest problem for anyone trying to learn without formal guidance is how to select - what to read, what to look at, what to study. As Carlos Fuentes put it, it is difficult to know how to know. This brings us to my second theme, namely the question of the status, legitimacy and recognition of knowledge. It was no coincidence that José Hernández's ringing denial of the applicability of European knowledge to Argentina happened during the 1880s. In most countries of Latin America there was greater political stability in this decade than hitherto, combined with an upturn in international trade, which stimulated economic growth. There was an expansion in the capacities of the state and an array of nation-building initiatives. In this section, I will illustrate the corresponding emergence of a conception of 'national' knowledge, as distinct from 'foreign' knowledge. 


\section{The emergence of 'national' knowledge in the late nineteenth century: Art}

In the same way that nations emerged in reciprocal interaction with transnational processes, so was the scope for knowledge production shaped by the potential for recognition. During the 1880s several Latin American states began to offer scholarships to study art in Europe. Although budding artists in Lima or Buenos Aires could by then receive formal training in drawing, painting and sculpture, the problem remained that there were still very few opportunities to see the works of art deemed to be canonical: art galleries, museums of fine art, even printed images in newspapers, all came at least a decade later. Students knew all about European art from written accounts, but they could not actually see it, beyond the few isolated prints or sculptures to be found at random in bookshops or dioramas. The glossy art books produced in Europe were deemed too expensive for Latin American markets, although the emerging international trade in artefacts began to target its wares at the newly rich of Latin America, selling them paintings and sculptures, often of indifferent quality, made especially for export. During this specific transitional period, lasting no more than a couple of decades, a visit to Europe, especially Italy and Paris, became a rite of passage for any aspiring artist, just as the Grand Tour had earlier been for the young adults of wealthy families. These artists were mostly from immigrant families of modest means, and dependent upon government grants to travel. Although the scholarships were not generous, they imposed significant expectations on their recipients. Artists from Latin America eking out an existence in Paris or Rome felt that in order to justify their state funding they needed not only to be successful - by getting their work into the French Salon or the Venice exhibition and winning European prizes - but also somehow to be representative of their native country. They were caught between two courts of public opinion: if they were intentionally and obviously 'national' in terms of content, they would go unrecognized in Europe, but if they avoided 'national' subjects they ran the very real risk of being accused of having cut themselves off from their roots in their native land. ${ }^{18}$

In the midst of these multiple pressures, however, artists from Latin America carved out plenty of scope for debating what 'national' art might mean. One interesting case is Martín Malharro (1865-1911), who was born in a small town in Buenos Aires province. Living in Europe from 1895 to 1901, without either a scholarship or family resources, he earned his living as an illustrator for Le Figaro and other publications. 
On his return to Argentina he had a successful exhibition of his paintings. Often described as a 'self-made man', whose 'independent spirit rebelled against any influences, making him a true original', ${ }^{19}$ he was actually trained in Buenos Aires printing workshops and then at the free classes run since 1879 by the private Society for the Promotion of Fine Art. In Paris, as his own letters show, he spent his whole time exploring museums and galleries, endlessly looking, studying and comparing. ${ }^{20}$

Back in Buenos Aires in 1903, by which time a Museo Nacional de Bellas Artes had been founded (1896), albeit not yet opened to the public, Malharro inveighed against what he called 'patrioterismo' (chauvinism or jingoism) in art, arguing that 'Art is a unity, without flags or pennants'. ${ }^{21}$ Any art 'had to be national', he argued, in the sense that it was bound to be a reflection of a specific cultural environment: 'if we take into account that the conception of feeling and of action is not the same in our land as it is in Europe, just as it is not the same in Europe as in Japan or China, we will find that there cannot be any universal ideal of beauty in an absolute sense'. Yet those nations conventionally associated with great art were those whose artists were deemed to have transcended their national context, painting 'without patrioterismo, without any ideal other than Art'. Thus, those cultural gatekeepers who lauded 'Italian' art or 'French' art were trying to have it both ways, enthroning 'absolutes that had no more value than the sly artifice' behind them. But given the established recognition of Italian and French art as both national and universal, any artist born in Argentina was obliged to forget - which meant first having to learn - 'all the best from the European schools of art'. Thus, for an artist from anywhere deemed to be peripheral, winning recognition even as national, let alone universal, entailed challenging global hierarchies of knowledge that excluded all but the most culturally confident societies from the possibility of transcending local specifics.

The knowledge hierarchies woven into the connections between centres and peripheries have had major consequences in the fields of economics and politics as well as culture. Elsewhere, I have analysed a series of major infrastructure projects in Latin America in the light of the tensions between science and sovereignty. ${ }^{22}$ My findings suggest that the oft-reiterated claims that Latin American countries 'needed' foreign technical expertise in order to develop - because they lacked sufficient home-grown expertise - are almost wholly unfounded. In the 'century of engineers', as Jürgen Osterhammel has characterized the 1800 s, ${ }^{23}$ these case studies vividly convey that it was not so much a question of local expertise being lacking as of its being undervalued. Here, I will explore the example of port facilities at Buenos Aires. 


\section{Argentina's 'first engineer' and the port of Buenos Aires}

Buenos Aires is a famous and significant port, but it is not a natural one. Shallowness, silting, sand banks drifting in wayward winds and tides - all make for major engineering challenges. As late as the 1980s, when the Argentine government defied the United States by selling grain to the Soviet Union, not the least of the problems involved in this act of Cold War brinkmanship was that the huge Soviet grain tankers could not dock at Buenos Aires. Even today, there is a constant need for dredging. It is hardly surprising, then, that its nineteenth-century development was fraught with difficulties. By 1870 all that there was to show for repeated attempts to build a modern wharf was a heap of discarded plans. These frustrations were caused partly by political factors - a series of costly wars, both internal and external, and the uncertain constitutional status of the City of Buenos Aires in relation to the rest of the country - but also by a lack of consensus about the best technical solution and the consequent difficulty of securing finance for a project fraught with risk.

In the late nineteenth century, the building of a new port caused the first public controversy in Argentina that could meaningfully be described as national. It was played out in the two recently founded national newspapers, La Nación and La Prensa, which took opposite sides. The protagonists were Luis Huergo (1837-1913), the man known as 'the first Argentine engineer' because he was the first to graduate, in 1870 , from the engineering degree newly established at the University of Buenos Aires, and Eduardo Madero (1823-94), a wealthy businessman and international trader. Huergo was already a public figure, elected to Congress while still a student. He was a founder and first president of the Argentine Scientific Society (1872). Unusually for an Argentine at that time, he had been educated in the United States, at a Jesuit college in Maryland, where he learned English. Back in Buenos Aires, he trained first as a surveyor, then from 1865 as an engineer. In contrast, Madero, who had inherited a role in his family's business, had no technical training. However, after spending several years in Montevideo, he returned to Argentina preoccupied, some said obsessed, with ensuring that Buenos Aires had the modern facilities that would enable it to trump Montevideo's natural advantages. By 1870 he had already presented two plans for the development of Buenos Aires, both drawn up in collaboration with British engineers, neither of which had garnered sufficient political support. 
There was a long-established practice, dating back to the 1820 s, of inviting European - mostly British - engineers to tender for the modernization of Buenos Aires port. In 1870, President Domingo Sarmiento commissioned yet another foreign expert to find a solution: John F. Bateman, whose plan - drawn up after spending less than a month in Buenos Aires - involved cutting a long canal in order to build the docks close to the heart of the city. It attracted 'a deluge of criticism' from locals, who argued that Bateman had completely underestimated the problems and the costs involved in such extensive dredging. ${ }^{24}$ A government-appointed Commission made up mainly of other 'foreign engineers' concluded that it would cost at least seven times what Bateman had estimated. ${ }^{25}$

It was in this context that Luis Huergo successfully argued for the development of the existing facilities at the alternative site of Riachuelo, just south of the city centre, in the area now known as Boca. As a reformist politician, recently elected as senator for the Province of Buenos Aires, one of his main concerns was to avoid the exorbitant costs he anticipated from pursuing any version of Bateman's idea. ${ }^{26} \mathrm{He}$ sought a realistic proposal not a prestige project. Huergo's plan was supported by both politicians and engineers. It received state funding in 1876 and by 1883 works had progressed so well that one of the new transatlantic steamers, L'Italia, was able to dock at Buenos Aires for the first time. This event was hailed in the press, both in Italy and Argentina, as a vindication of the plan devised by 'a creole engineer, without authority in the scientific world and in opposition to the powerful opinions of an expert of European fame like Mr Bateman'. ${ }^{27}$

In light of this success, in 1882 Huergo submitted detailed plans to extend the docks northwards. The next thing he knew, apparently from reading it in the press, was that the government had decided instead to back a third plan championed by Eduardo Madero, drawn up by the British company of Hawkshaw, Son \& Hayter, with the promise of finance from Barings. Madero had returned from a visit to London, sought an urgent meeting with President Roca (which he obtained through the good offices of his uncle, the Vice-President), and persuaded Roca to support a plan supposedly designed by the great engineer Sir John Hawkshaw. In fact, Sir John had handed the project over to his son, who in turn passed it on to someone else. In general, the company specialized in railways, rather than port works. The plans were very sketchy and had been drawn up without even the briefest of visits to Buenos Aires; they ignored Riachuelo and all the existing facilities; they were very similar, with the same problems, to those of Bateman's plan rejected in 1871 . 
Yet Madero's proposal was forced through Congress by President Roca, without consulting the Argentine Department of Engineers.

The Congress did, however, stipulate that the final version of the plans had to be endorsed by the Department of Engineers. The government first tried to circumvent this requirement by establishing a Commission of Experts, two out of the five of whom were English and US engineers. This Commission reported that the drawings Madero had supplied were too sketchy to evaluate. What happened then, it later emerged, was that the President simply summoned the head of the Department of Engineers and ordered him to ensure that a set of suitable drawings was made, along the lines indicated by Hawkshaw, Son \& Hayter. ${ }^{28}$ When these supposedly 'definitive' plans were presented in 1884 , they were approved by decree and Roca summoned three former presidents, no less - Mitre, Avellaneda and Sarmiento - to sign the contract with Madero. ${ }^{29}$ This public display of official preference for British over Argentine expertise unleashed a storm of criticism. The Argentine Assembly of Engineers of 1886 was unequivocal in concluding that 1) Hawkshaw, Son \& Hayter's plan would not result in a good port for Buenos Aires (on the contrary, the high costs of its construction and operation would 'impose a burden incompatible with the general interests of trade'); and 2) Huergo's far more detailed design not only met 'the technical, general and commercial demands of a port for Buenos Aires', but also would cost only a third of Madero's plan. ${ }^{30}$ Nevertheless, the government went ahead with the Madero-negotiated contract. Huergo and the head of the Department of Engineers both resigned and were supported not only by their colleagues, but also by thousands of people who turned out to cheer the awarding of a medal to Huergo in Boca del Riachuelo. ${ }^{31}$ Work on what became known as Puerto Madero began in 1887 and was completed a decade later. The project ran way over budget: even the supportive La Nación (19 January 1919), estimated, conservatively, that it had cost at least twice the amount originally specified; French engineers dubbed it 'the most expensive port in the world'. ${ }^{32}$ It was already congested by 1902 and ceased functioning altogether in 1925. In 1909 the government decided to build a new port, along the lines of what Huergo had envisaged back in 1882.

There are two key points in this story. The response of the English engineers to any of the specific criticisms set out by locally based engineers was to claim that their proposals were 'as advised by modern science and practice'. ${ }^{33}$ Yet the experienced and distinguished Luis Huergo had actually done more than most individuals anywhere to modernize engineering. He carried out many other inventive projects including sanitation and irrigation works throughout Argentina and in Paraguay, 
always undertaking extensive research into human health and nutrition to inform his engineering. ${ }^{34}$ Despite all of these pioneering scientific endeavours, Huergo was denied the mantle of modern expertise.

The second point - which is perhaps even more telling - is that President Roca could not have secured the drawings he needed to force this project through Congress had it not been for the fact that an engineering degree had been started at the University of Buenos Aires in 1865, creating a cohort of trained, capable staff at the government Department of Engineering. Roca was reliant upon home-grown expertise to rectify the technical defects in the work done by the foreign company he wished to impose.

\section{Conclusion}

The examples above illustrate what can be gained by thinking about the history of knowledge as a collective endeavour, involving a wide variety of people beyond the famous intellectuals who are often at the centre of historians' attention. Switching the focus to other, apparently marginal figures, may light up the shadowy configurations of power that shape the possibilities for knowledge creation in any particular time and place. As research from many fields has shown, the margin can be a place of creativity, empowerment and renewal, but my evidence supports the argument that it is nonetheless crucial not to lose sight of the wider asymmetries that embed the marginal. The framework of centres and peripheries runs the risk of reifying these distinctions and imbalances, but if flexibly conceived as a spectrum of relational possibilities it can be helpful in enabling historians to bring together big-picture analysis and fine-grained interpretation of historical shifts in distributions of power.

The evidence from this chapter also draws attention to the importance of thinking not only about cognition but also about recognition. The scholarly literature still tends to emphasize either the creation of knowledge and how that is shaped by coloniality, or networks of knowledge circulation and how they decentre hierarchies of material power. Yet far less work has been done on fundamental processes of legitimation, which are equally subject to power relations both within and beyond sites of production or routes of dissemination. It is one thing to control access to knowledge, but who decides what actually counts as knowledge? Everybody has always borrowed ideas and techniques from elsewhere, as Voltaire neatly conceded when he defined originality as judicious imitation. Over the course of the nineteenth century, however, various 
forces combined to create hierarchies of knowledge in which some acts of imitation were celebrated as of universal interest and others were dismissed as only of local relevance. As postcolonial scholars have shown, concepts, classification systems and disciplines specific to the local contexts of Europe were gradually projected, through imperial power, as being of universal validity. The independent countries of Latin America, evolving both after colonialism and during the rise of neo-colonialism, carried out nation-state-making in the midst of the coalescing global hierarchies of knowledge of the nineteenth century. Knowledge practitioners from elsewhere were increasingly denied universal reach, instead being expected - both abroad and at home - to be authentic expressions of their local culture. The poet César Vallejo, living in Paris in the 1930s, eloquently evoked the anguish it caused him. 'Why do I always have to be "Peruvian" when I write?' he demanded. Even Lorca, from Spain, the metropolitan status of which had long been undermined by Black Legend stereotypes of backwardness and superstition, had succeeded in being accepted as a poet with a universal message. Yet Vallejo felt condemned to be national, denied the possibility that anything he said or thought could be deemed of interest beyond its relevance to the country where he happened to have been born; that is, he felt - and he was - denied the possibility of being fully human. Anyone who has read Vallejo's poetry will know that he spoke fully to the human condition. Nearly a century later, thanks in part to the work of scholars committed to thinking about transnationalism in all its varieties, this is beginning to be recognized. In this context, the centre-periphery framework helps to interpret the processes by which some kinds of knowledge, produced in certain places, at specific times, came to be recognized as generalizable to other places. It was not just the theft of history, to borrow Jack Goody's vivid phrase, ${ }^{35}$ but the theft of the right even to think about what 'history' might be.

\section{Notes}

1. José Hernández, Instrucción del estanciero: tratado completo para la planteación y manejo de un establecimiento de campo. Buenos Aires: Imprenta y Librería de Mayo, 1884; republished Buenos Aires: Claridad, 2008. The insistence on local conditions of agricultural development shows striking similarities to the examples discussed by Marta Petrusewicz in her contribution to this book.

2. Ricardo Newton and Juan Llerena, Viajes y estudios de la Comisión argentina sobre la agricultura, ganadería, organización y economía rural en Inglaterra, Estados Unidos y Australia. Buenos Aires: Imprenta La República, 10 vols, 1882-4.

3. Benedict Anderson, Imagined Communities: Reflections on the Origin and Spread of Nationalism. London: Verso, 1983. 
4. For two inspiring examples, see Irina Podgorny and María Margaret Lopes, El desierto en una vitrina: Museos e Historia Natural en la Argentina. Rosario: Prohistoria Ediciones, 2014; and Máximo Farro, La formación del Museo de La Plata: Coleccionistas, comerciantes, estudiosos y naturalistas viajeros a fines del siglo xix. Rosario: Prohistoria Ediciones, 2009.

5. Francisco Castañeda, 'Alocución o arenga patriotica', 10 August 1815. Buenos Aires: Imprenta de Los Niños Expósitos, 1815.

6. For example, Camilo Henríquez, 'Escuela gratuita para la práctica del dibujo', 1815, in Juan María Gutiérrez, Origen y desarrollo de la Enseñanza Pública Superior en Buenos Aires [1868], edition by Universidad Nacional de Quilmes, 1998, 218-20.

7. Mary Takahashi Huamancaja, La pintura de miniatura en Lima durante la primera mitad del siglo xix: El caso de doña Francisca Zubiaga de Gamarra. Lima: Universidad Nacional Mayor de San Marcos, 2006.

8. For example, Emeric Essex Vidal, Picturesque Illustrations of Buenos Ayres and Monte Video. London: Ackermann, 1820.

9. M. A. Fuentes, Lima: apuntes históricos, descriptivos, estadísticos y de costumbres. Paris: Librería de Firmin Didot, 1866. Ricardo Palma, Tradiciones peruanas, con láminas inéditas [...] de Pancho Fierro. Barcelona: Oceana, 1982.

10. Francisco Stastny, Breve historia del arte en el Peru. Lima: n. p., 1967, 50-51.

11. The main work, on which this section draws substantially, is Natalia Majluf, 'Pancho Fierro, entre el mito y la historia', in Marcus Burke and Natalia Majluf, Tipos del Perú, La Lima criolla de Pancho Fierro. Madrid: Ediciones El Viso y The Hispanic Society of America, 2008, 17-50.

12. Alexander von Humboldt, Personal Narrative of a Journey to the Equinoctial Regions of the New Continent [1814-25], trans. and abridged by Jason Wilson. Harmondsworth: Penguin, 1995. Humboldt's scientific findings from his time in the Americas ran to thirty volumes (1807-34). On other expeditions, see Tim Fulford and Peter J. Kitson, eds, Travels, Explorations and Empires: Writings from the Era of Imperial Expansion 1770-1835, vol. 7, Latin America and the Caribbean. London: Pickering and Chatto, 2001.

13. Majluf, 'Pancho Fierro', 25-7.

14. There are no easy equivalents for the Spanish terms. Dibujante is usually translated 'draughtswoman or draughtsman', but that is to introduce a distinction between technical and artistic drawing that did not emerge clearly in Latin America until the mid-nineteenth century.

15. Quotation from Stastny, Breve historia, 51; on Fierro's entrepreneurship, Majluf, 'Pancho Fierro', 28.

16. Majluf, 'Pancho Fierro', 33-4.

17. Stastny, Historia breve, 52.

18. Laura Malosetti Costa, ed., Cuadros de viaje: artistas argentinos en Europa y Estados Unidos, 1880-1910. Buenos Aires: FCE, 2008; see her introduction, 'Artistas viajeros en la belle époque', 13-49.

19. Ricardo Olivera, cited by Malosetti Costa, Cuadros de viaje, 245-6.

20. Martín Malharro, 'Carta a Eduardo Schiaffino', Paris, 14 November 1895, in Malosetti Costa, Cuadros de viaje, 239-43.

21. Martín Malharro, 'Del patrioterismo en el arte', 1903, in Malosetti Costa, Cuadros de viaje, 252-6.

22. Nicola Miller, Republics of Knowledge. Princeton, NJ: Princeton University Press, forthcoming, 2019.

23. Jürgen Osterhammel, The Transformation of the World. Princeton and Oxford: Princeton University Press, 2014.

24. On the reaction to Bateman's plans, see Hernán Huergo, Luis A. Huergo y la cuestión Puerto. Buenos Aires: Editorial Dunken, 2013, 33-4.

25. Huergo, Luis A. Huergo y la cuestión Puerto, 33-4. For primary materials, see Documentos relativos a la Cuestión Obras del Puerto de Buenos Aires e Informe del Injeniero J. F. Bateman. Buenos Aires, 1870.

26. Luis A. Huergo, Los intereses argentinos en el Puerto de Buenos Aires. Buenos Aires : n. p., 1873.

27. Quotation from La Prensa, cited in Hernán Huergo, Luis A. Huergo, 37.

28. Martha Mayorano, Un ingeniero, un puerto: Luis A. Huergo: primer ingeniero argentino. Buenos Aires: Editorial COGTAL, 1992, 208.

29. Hernán Huergo, Luis A. Huergo, 55. 
30. Asamblea de Ingenieros, 'Informe de la Comisión y Resolución de la Asamblea', 30 March 1886, in Luis A. Huergo, Examen de la propuesta y proyecto del puerto del Sr Eduardo Madero, discusión franca. Buenos Aires: Imp. de M. Biedma, 1886, 189-91. For an indication of Madero's perspective, see his Historia del Puerto de Buenos Aires [1892, 1902], 3rd edn. Buenos Aires: n. p., 1939.

31. Hernán Huergo, Luis A. Huergo, 61.

32. Hernán Huergo, Luis A. Huergo, 76-7.

33. Hernán Huergo, Luis A. Huergo, 42.

34. Hernán Huergo, Luis A. Huergo, 67-8; see also José Isaacson, Luis Augusto Huergo: Primer ingeniero argentino. Ciencia y técnica en el proceso cultural del Rio de la Plata. Buenos Aires: Academia Nacional de Ingeniería, 1993.

35. Jack Goody, The Theft of History. Cambridge: Cambridge University Press, 2006. 


\section{From Manchester and Lille to the World: Nineteenth-century Provincial Cities Conceptualize their Place in the Global Order}

Harry Stopes

\section{Introduction}

Hindle Wakes is one of the few plays written by the Manchester playwright Stanley Houghton (1881-1913) which still enjoys some fame today. ${ }^{1}$ It was a sensation when it was first performed in 1912, quickly transferring to London after a short run in Manchester. Later the same year it received its international première in New York. ${ }^{2}$

One of the principal characters of the play is Alan Jeffcote, the son of a wealthy cotton manufacturer in Hindle, a fictional Lancashire town on the outskirts of Manchester. He is described in the stage notes as follows:

He is dressed by a good Manchester tailor, and everything he has is of the best. He does not stint his father's money. He has been to the Manchester Grammar School and Manchester University, but he has not lost the characteristic Hindle burr in his accent, though he speaks correctly as a rule ... He has no feeling that he is provincial, or that the provinces are not the principal asset of England. London he looks upon as a place where rich Lancashire men go for a spree, if they have not time to go to Monte Carlo or Paris. Manchester he looks upon as the centre or headquarters for Lancashire manufacturers, and therefore more important than London ... The feeling gives him sufficient assurance to stroll into the most fashionable hotels and restaurants, conscious that he can afford to pay for 
whatever he fancies, that he can behave himself, that he can treat the waiters with the confidence of an aristocrat born - and yet be patently a Lancashire man. He would never dream of trying to conceal the fact, nor indeed could he understand why anybody should wish to try and conceal such a thing. ${ }^{3}$

Though this is a fictionalized description, the author was drawing on his own experience. Houghton, the son of a cotton merchant, was born in Ashton-under-Lyne, near Manchester, in 1881. Like his creation, he was educated at Manchester Grammar School and then went to work in his father's business. Young men like Jeffcote were a feature of his everyday experience: taking the train to work in the warehouse on Whitworth Street, reading the paper in the Reform Club, drinking in the bar of the Midland Hotel. In Houghton's description, Jeffcote's central characteristic is a sense of certainty in his social status that was rooted in his economic position and his identity as a Mancunian and a Lancastrian. He was sufficiently confident in himself to feel that he belonged in a global elite but, paradoxically, the security of this sense depended upon his deep roots in a local identity. When he thought of England, and indeed of Europe, the imagined geography upon which he drew did not recognize centres and peripheries, or if it did it reversed them: Manchester was central, London was not.

As I argue in this chapter, Jeffcote's worldview, as described by Houghton, is a revealing fictionalized presentation of a value widely shared among members of the elite in the industrial cities of Manchester and Lille at the turn of the nineteenth and twentieth centuries. This was the conviction that modernity was best navigated at the scale of the local, using social structures and cultural ideas that took their form at the local scale. As they reacted to and made sense of economic globalization and transnational cultural exchange, the middle classes of Manchester and Lille rooted their responses in ideas of the local, drawing upon an idea of global space that was not always hierarchical, that did not always run from the provincial periphery to the metropolitan centre. On the contrary, the provincial city could be central, and could make connections with the rest of the world on its own terms. ${ }^{4}$

This chapter argues in opposition to a longstanding tendency among historians and other social scientists, for whom the idea of 'centres and peripheries' has commonly shaped their readings of nineteenthand twentieth-century Europe. This approach has been rooted, I would argue, in the continued importance of the paradigms of 'modernity' and 'nationalism' to their accounts. Nationalism has commonly been regarded 
as the most powerful theory of political legitimacy in the nineteenth century: an extensive historiography has traced its development beginning in the late eighteenth century. ${ }^{5}$ Modernity too has been conceived both as a way of understanding the changed nature of human experience in the face of industrialization, and as a means of naming and conceptualizing related social, political and cultural developments. ${ }^{6}$ Both continue to be important to historians and social scientists, both as objects of investigation in themselves, and as useful conceptual frameworks with which to approach empirical problems.

However, where theories of nationalism have posited the decisive role played in nation-building by social elites, generally associated with one geographic place within the national territory (usually the royal court or national capital), and accounts of modernity have identified its cultural manifestations in large cities as archetypal and definitive, both have tended towards a hierarchical understanding of European and global spaces. Nations have their central core and provincial peripheries, while modernity itself is seen as emanating from particular central places to peripheries. ${ }^{7}$ This teleological tendency relegates sub-national places to a secondary role.

Despite its geographically enlarged frame of reference, global history, too, risks embedding hierarchical understandings of space into its explanatory models. A focus on connections and networks - say, between Lebanese diaspora merchants - might identify Abidjan and São Paulo as local 'centres' in a global circuit of capital, with their hinterlands as peripheral regions in peripheral parts of the world. Histories of international organizations or state diplomacy may also reproduce the spatial logic of the objects of study. Attempts to understand modern global history in terms of the development of whatever process is thought to drive that history - say, industrial capitalism - centre the process and thus also produce their own spatial hierarchies, contrasting central industrial cities with peripheral producers of raw materials. In response to such criticisms, often framed as a problem of 'Eurocentrism', there have been urgings to 'provincialize', 'decentralize' or 'fragment' the field of global history, a call which should inform the way that global space is modelled. ${ }^{8}$

In this chapter I aim to take on this challenge by critically examining the paradigms of nationalism and modernity in the light of recent scholarship, with reference to two case study cities at the end of the nineteenth century. In a context of economic globalization and cultural globalization, elites in Manchester and Lille - two supposedly peripheral, provincial cities - engaged with debates about national identity and modernity on their own terms, rather than ceding the intellectual terrain to capital 
cities. Through an examination of the ways they used municipal policy to articulate ideas about the relationship between the city and the rest of the world, I argue that they did not understand their cities to be peripheral, neither in their respective national contexts nor at the global scale as they understood it. I show that the building of models with which to make sense of global space must not mean sorting that space into graded hierarchies of centres and peripheries, but something more complex. In the concluding paragraphs I discuss how this might look.

\section{The role of opera}

The art of the opera has long played a vital role in histories of politics, society and culture in nineteenth-century France. Opera houses in Paris were handsomely subsidized by successive regimes, while changes in the art form itself were commonly presented by contemporary observers as related to wider changes in French society. ${ }^{9}$ A vast literature has explored this rich history, focusing particularly on the most celebrated composers and impresarios, and the developments of the art in Paris. ${ }^{10}$ This literature has framed the opera, as a historiographical problem, as a question of national identity and national politics. 'No signal could have been stronger: [the opera] was as important to Napoléon III's government as the railways, the military, and probably the Church. ${ }^{11}$ When transnational connections have been considered, for example in the influence of Italian composers or of Richard Wagner, the focus has still been on Paris as the reception and transmission point of foreign influence.

Yet the opera was the central art form of urban life throughout France, playing a crucial role in the shaping of civic identity. To maintain a healthy municipal opera theatre was a mark of a sophisticated modern city, and an important preoccupation of municipal councils and mayors across France, and indeed Europe. ${ }^{12}$

Lille was never an internationally important centre of opera in the same sense as Paris. Nevertheless, even the fairly average talents that made up the permanent company of a city like Lille were part of a European employment market by the 1860s. Jules-Henry Vachot, the director of the opera in the 1865-6 season, had formerly been director of the Ghent and Antwerp theatres. After leaving Lille he returned to Belgium to manage La Monnaie in Brussels, at the time considered one of the finest opera theatres in Europe. He later returned to Paris, where he died in $1884 .{ }^{13}$ Eugène Bertrand, director in $1867-8$, a year local theatre historian Léon Lefebvre called 'one of the finest the Lillois had seen for 
20 years', had spent five years managing theatres in the United States of America, as well as time in Brussels. ${ }^{14}$ Under his direction Adeline Patti gave her first performance of Faust in French. ${ }^{15}$ He later became manager of the Paris opera. Biographies of the hundreds of performers and directors in Lefebvre's history of the Lille theatre demonstrate that such mobility was the norm, while listings in the Parisian theatrical and musical press show that this was the case elsewhere too. ${ }^{16}$ Efforts to raise or maintain the quality of the local opera were framed in a comparative register, with municipal councillors making repeated reference to the international character of the art form in their discussions on the subject. ${ }^{17}$

At the same time as investing political capital in emulating cities across Europe, municipal political elites in Lille asserted their independence from Paris. In the late nineteenth century Paris lost its pre-eminence and its reputation for producing important new works of Grand Opéra, a genre which had dominated the mid-century art form. In some years during the 1870s there were no new works at all performed at the Opéra Garnier. ${ }^{18}$ Some music critics and interested political observers became concerned that the Paris-centred system, particularly the emphasis placed on Grand Opéra, did not afford young dramatists and composers the opportunity to experiment and to bring their works to new audiences. ${ }^{19}$ Some began to develop a set of ideas and policies that associated the possibility of a regenerated French opera with a revival of the operatic scene outside Paris. This policy agenda came to be known as 'theatrical decentralization' (décentralisation théâtrale).

For the liberal republican Géry Legrand (1837-1902), mayor of Lille from 1881 to 1896, theatrical decentralization meant revitalizing the repertoire by increasing the number of works performed each season that had not previously been staged in Lille. Upon his election he revised the cahier des charges (a document which specified the terms and conditions of the opera director's engagement) to specify that at least three new works should be performed each season. ${ }^{20}$ In comparison, just two new works per season were required at the Opéra Garnier in the same period. ${ }^{21}$ The revised cahier also gave the mayor the power to mandate the director to stage up to two new works per season by Lillois composers or writers, if suitable works were available. It was for this reason in particular that Legrand was recognized as a 'partisan' of decentralization by a local theatre historian. ${ }^{22}$

The most interesting product of this moment in the Lille opera was a work called Lydéric, a new opera performed in Lille in 1895 and 1896. ${ }^{23}$ Its composer was a man called Émile Ratez, and the lyrics were written by two local journalists. Ratez was born in Besançon and studied in Paris, 
but later became 'a Lillois ... by adoption', spending forty years as director of the Lille conservatoire. ${ }^{24}$

Lydéric was based upon the legend of Lydéric and Phinaert, a medieval epic poem, elements of which appeared in various Latin, French and Flemish versions between the eleventh and sixteenth centuries. ${ }^{25}$ Lydéric was a kind of popular local hero, regarded as the founder of the city. Giant figures of the two characters were popular features of the Lille carnival, and Lydéric was celebrated in local literature, both in the dialect poetry of Alexandre Desrousseaux, and in conventional verse by local hommes des lettres. ${ }^{26}$ The story was widely known, with Lydéric the 'popular hero' of the people of Lille. ${ }^{27}$ In other words, this opera, by a local composer, told a very local story.

Despite its locally derived story and its emergence from a municipal policy of favouring local works, the opera was consistent with wider trends within the avant-garde of French opera. Lydéric belonged to the genre of drame lyrique, ${ }^{28}$ a form that had come to replace Grand Opéra, and had largely been associated with French wagnerism. ${ }^{29}$ Ratez's opera was recognized as being 'modern' and 'Wagnerian' in its musical style, both by hostile reviewers and those who praised the work. ${ }^{30}$ Ratez had 'the skill and the science of a serious musician' according to one local periodical, ${ }^{31}$ while a review in a local paper claimed that 'he is from this modern school of which the formula goes like this: to abandon entirely the form of opera with a series of airs in duets or trios, with no link attaching one to the next; to achieve the intimate union of the poem and the music, by giving to the vocal and symphonic parts their appropriate place; and doing so by the constant employment of characteristic motifs. ${ }^{32}$ The prominent Wagnerian critic Louis de Fourcaud had two years earlier named Ratez among a list of seven young composers who in recent years had played 'an important part in the movement of the modern [musical] art'. ${ }^{33}$

Lydéric therefore illustrates two important things. Firstly, that experimentation with new aesthetic techniques, including those inspired by the still controversial figure of Richard Wagner, did not take place only in Paris. Nor were Wagner's ideas transmitted into France solely through Paris. The process of cultural exchange and influence was more diffuse than that, involving supposedly peripheral places like Lille. Secondly, rather than responding to Wagner only in terms of the challenge he posed to French music or to French identity, the composer of Lydéric instead took the Wagnerian model of sweeping mythical storytelling and innovative compositional techniques, and applied it to a local myth, rooted in civic identity and local popular culture. Lydéric therefore 
demonstrates that peripheral spaces too could be the site of modernist innovation, while the context of its creation underlines the capacity of sub-national political formations to take on the role of cultural patrons, participating in the development of a modern art form independently of national trends. ${ }^{34}$

\section{The art gallery and the city}

Around the same time, in Manchester, the city art gallery was a focal point for debates about the relationship between the city and an increasingly globalized artistic culture. Thanks to the raising of a $£ 2,000$ per annum fund for new purchases, launched in 1882 by the city council, by 1897 the permanent collection was 'one of the best of its kind outside London', according to the council's Art Gallery Committee. ${ }^{35}$ From just 18,000 in 1884 , by the end of the century this collection received over a quarter of a million visitors a year. As the collection continued to expand, and new exhibition conventions developed - particularly the practice of hanging pictures at eye level in a single row, rather than all over the wall at various heights - it was increasingly difficult to find sufficient space for the collection. In common with other British cities at the time, Manchester needed more space for its gallery. ${ }^{36}$ In 1900, the lack of space cost the city the donation of a collection of more than a thousand items, including oil paintings by Botticelli, Rembrandt and Delacroix, which the Manchester-born Greek merchant Constantine Alexander Ionides gave to the Victorian and Albert Museum instead. ${ }^{37}$

In such a context, the perceived shortcomings of the Manchester art gallery were profoundly troubling for many Mancunians. For a loose coalition of city councillors, journalists, academics and amateurs of art, Manchester fell short in matters of culture, especially in comparison to its economic pre-eminence in cotton textiles. As their counterparts in Lille did when discussing the opera, they expressed their criticisms in comparative terms, looking to what had been done in other large cities in Britain and on the continent. ${ }^{38}$ In particular, though not exclusively, they looked to German cities as an example.

The city Art Gallery Committee settled upon a plan to build a new, much larger gallery. In March 1905 the mayor and three councillors set off on a tour of thirty-one galleries in Britain, France, Belgium, the Netherlands and Germany. Their itinerary included collections of oil painting, sculpture, decorative art, prints, drawings, industrial art, photographs, antiquities and local historical material. They met with gallery 
directors including Alfred Lichtwark in Hamburg and Wilhelm von Bode in Berlin, curators and conservators, and local politicians. ${ }^{39}$ In Munich they were welcomed to a ceremonial dinner with municipal councillors. The result of this research was an extensive report synthesizing their findings and making detailed proposals for the new gallery in Manchester. ${ }^{40}$

In taking lessons from their tour of the continent, the committee attempted to be synthetical, absorbing what they saw but adapting only those things that they regarded as relevant to the city, taking care to highlight areas in which Manchester's existing practices were more appropriate. Next to Dresden, for instance, 'Manchester compared favourably in regard to attendance, local interest, free entrance, and number of hours which the galleries are open for the pleasure of the public. ${ }^{41}$ They portrayed themselves as learning from galleries in Europe in order to create a better gallery adapted to local conditions, rather than simply setting out to create a facsimile of galleries they had encountered abroad.

Members of the Manchester Art Gallery Committee saw themselves as belonging in a social and cultural space whose boundaries were not identical with those of the nation. Believing that promoting artistic beauty could be both a means and an end of reform in the industrial city, they recognized that similar attempts were being conducted in other parts of Europe, where they were often more advanced. They therefore, on the basis of an identified affinity between Manchester and other cities in north-western Europe (especially Germany), set out to learn from the practice of those cities. Mancunian elites viewed the management of cultural institutions as a way both to respond to their experiences of globalization, and to make new connections across national borders. The art gallery was both a means of making Manchester into a European city, and an expression of the extent to which it already was.

Mancunians were able to make this conceptual and spatial leap thanks to the similarities that existed between the social and economic structure of Manchester and other cities, as well as the many cultural values that the bourgeoisie shared across Europe. While earlier moments of transnational connection such as the exhibition of German, French and Belgian artists held in 1860 had been achieved by the private Royal Manchester Institution, this time it was the municipal government that was the common, mutually comprehensible form that existed across the continent. As historians of the 'municipal moment' have noted, the building of connections between European and American cities in the late nineteenth and early twentieth centuries depended on the existence of 'transboundary connections between individuals [with] certain rules, principles and/or concepts in common'. ${ }^{42}$ 
Such connections included those between the Manchester councillors and the various officials and politicians they met on their trip in 1905. They also included the friendship that developed between Walter Butterworth and Édouard Herriot, the radical mayor of Lyon and later Prime Minister of France. This friendship dated to the visit of a group of Lyon councillors to the city in 1906, when Butterworth, as the best French speaker on the council, held many conversations with Herriot. They met again during a return trip to Lyon in May $1907 .{ }^{43}$ This trip to Lyon was to form the basis of the proposed textile gallery in Manchester, which had not been discussed at much length in the initial committee report. ${ }^{44}$ Butterworth - a polyglot who spoke eleven languages by the time of his death - was also a fluent speaker of German, which facilitated conversations with Lichtwark, Bode and others during the visit to Germany. Underlying such connections was the idea that the municipality was a common entity across different parts of Europe, and that municipalities could be compared with, or rival, their counterparts elsewhere. The existence - or perceived existence - of institutional similarity across borders was at least as important as the relationships formed between individuals.

In the proposals for a new art gallery, and the discussions surrounding their possible implementation, the European continent seems to have been perceived as something resembling a network of cities, rather than a patchwork of homogenous nations. Relationships could be formed and affinities identified that went across borders, without being conceived through the paradigm of the nation. When the Manchester delegation was in Munich, for instance, it was treated to a grand luncheon by the local council. In a speech, the mayor of Manchester presented himself first of all as an emissary of the city, rather than his country. He thanked his hosts 'heartily in the name of the city of Manchester, the great commercial city I have the honour to represent'. ${ }^{45}$ 'Art especially stands above geographical relations', he also said, '[and] we feel that you stretch out the hand of friendship from one town to the other'. This is not to claim that politicians in Manchester (or Munich) were not nationalists, or would not have sent their sons to fight in northern France nine years later, but rather that their plans for the art gallery were an opportunity for them to articulate a way of thinking about the European space in a way which did not foreground the nation.

Here the mayor evoked a sense that Manchester, as a great commercial and industrial city, was capable of establishing connections with other cities and other parts of the world. These relationships were not perceived through the prism of nationhood but rather of local character. Manchester need not be peripheral but could establish itself as a 
culturally (as well as industrially) modern city by emulating European cities such as Munich or Cologne that it perceived as being appropriate comparators. Vital to this way of seeing the relationship between the city and the rest of the world was a networked idea of global space in which connections between places were horizontal, not vertical.

The overriding conclusion of this chapter is therefore that elites in Lille and Manchester in the second half of the long nineteenth century developed their social, political and cultural lives around the theme of the 'local'. Though rooting themselves in this identity, at the same time they were connected to global economies and cultural trends, and aware of global events through the local press. They travelled abroad as far as their means would allow them, and gathered information on other parts of the world when they could not. As they made these global or transnational connections, their actions were guided in part by their ideas about local identity, both the identity of the industrial bourgeoisie, and the identity of the city. Manchester and Lille were not simply a British and a French city, they were cities in the world, connected to a network of transfers and exchanges in which they did not see themselves as playing a peripheral role.

\section{Conclusion}

This conclusion gives rise to three themes which lie outside the scope of this chapter itself but suggest avenues for further study within the context of the centres and peripheries project. These themes I have called roots, models and which worlds?

In this chapter I have explored the different ways in which elites in the two cities imagined the world. What I have addressed less explicitly, however, is how and why those imaginations came to be. What were the roots of provincial transnationality, and how and why did people in supposedly peripheral cities see themselves as central actors in the drama of modernity? Arguably, these roots belong in the cities' economies, for it was industrialization that brought the cities into relations with the rest of the world. Indeed it was industrialization that shaped them into their modern form, with decisive impacts on ideas of local identity. The tone and intensity of local discussions on this subject indicate that industrial production and exchange had acquired powerful symbolic meanings that were intertwined with local identity. While the cultural resonance of technological change in the nineteenth century is a subject that historians have already worked on at great length, local iterations of this effect have been comparatively neglected. The uneven and distributed nature 
of economic development in the nineteenth century, a fact increasingly recognized by historians of industrialization, makes a hierarchically graded model of global space increasingly difficult to sustain. ${ }^{46}$

How therefore should we model the imagined geographies of provincial elites? The nationalist world geography encodes within it a hierarchical idea of space: from locality to nation, and thereafter to world. As Jürgen Osterhammel called it, this represents 'a size-graded hierarchy of settlements stretch [ing] up pyramid-like ... from a multiplicity of villages at the bottom to a central location at the top. ${ }^{47}$ This clearly does not represent the imagined geographies of the people I have described in this chapter. For them, the global space was not vertically integrated, and transnational connections from their cities did not pass through, either literally or conceptually, a national capital or an idea of the nation. For them, transnational connections were horizontal, and the city existed in a network of connections in all directions, some stronger and some weaker, in a global space that shrank and stretched in uneven ways.

Finally, as we have recognized the uneven nature of the connections that develop with globalization, it will not do to speak of 'the city and the world'. Which worlds? This study suggests that in constructing an imagined global geography Mancunians and Lillois sorted the planet into many worlds, each defined by particular characteristics. When they thought of opera, Mancunians referred to Italy or perhaps Germany; when Lillois thought of painting their minds turned to Flanders; for Mancunians the best universities and art galleries were in Germany; Africa contained virgin markets and racial Others; raw cotton came from America, but was spun in Manchester. This differentiated global geography conformed to the self-perception of the two cities: the division of the world into regions defined by their cultural or economic products mirrored the definition of the home city by its industries. This worldview was represented daily in the rubric of the local newspapers. As a cotton spinner like Jules-Émile Scrive spread the Écho du Nord over his breakfast table, no doubt his eye would turn to the financial pages, where he would find news of the harvest in Mississippi, and the price of a bale in Manchester.

\section{Notes}

1. 'Houghton, Stanley' in Dennis Kennedy, ed., The Oxford Encyclopedia of Theatre and Performance. Oxford: Oxford University Press, 2003. Hindle Wakes was revived in the West End in the summer of its centenary year.

2. 'Only one new play will demand the attention of theatregoers this week ... 'Hindle Wakes,' imported with its acting company from London.' 'This Week's Offerings,' New York Times, 8 December 1912. 
3. Stanley Houghton, Hindle Wakes. Oxford: Heinemann, 1988, 27-8.

4. The argument outlined in this chapter is discussed at much greater length in my recently completed doctoral thesis: Harry Stopes, 'Provincial Modernity: Manchester and Lille in Transnational Perspective, 1860-1914', PhD thesis, University College London, 2017.

5. Timothy Baycroft, Culture, Identity and Nationalism: French Flanders in the Nineteenth and Twentieth Centuries. Woodbridge: Boydell \& Brewer, 2004, 2; Benedict Anderson, Imagined Communities: Reflections on the Origin and Spread of Nationalism, revised edition. London and New York: Verso, 2006; Ernest Gellner, Nations and Nationalism, second edition. Ithaca, NY: Cornell University Press, 2009; Eric Hobsbawm, Nations and Nationalism Since 1780: Programme, Myth, Reality. Cambridge: Cambridge University Press, 1990; Hugh Seton-Watson, Nations and States: An Enquiry into the Origins of Nations and the Politics of Nationalism. Boulder, CO: Westview Press, 1977; John Breuilly, Nationalism and the State. Manchester: Manchester University Press, 1993.

6. Reinhart Koselleck, 'Concepts of Historical Time and Social History', in The Practice of Conceptual History. Palo Alto, CA: Stanford University Press, 2002, 119; Jürgen Habermas, The Philosophical Discourse of Modernity: Twelve Lectures. Cambridge, MA: MIT Press, 1987, 5; Reinhart Koselleck, 'The Eighteenth Century as the Beginning of Modernity', in The Practice of Conceptual History, 155; Raymond Williams, Keywords: A Vocabulary of Culture and Society, revised edition. Oxford: Oxford University Press, 1983, 208-9; Bjorn Wittrock, 'Modernity: One, None, or Many? European Origins and Modernity as a Global Condition', Daedalus 129: 1 (2000): 47.

7. Eugen Weber, Peasants into Frenchmen: The Modernization of Rural France, 1870-1914. Palo Alto, CA: Stanford University Press, 1976; Dipesh Chakrabarty, Provincialising Europe: Postcolonial Thought and Historical Difference, second edition. Princeton: Princeton University Press, 2008, 7.

8. Benedikt Stuchtey and Eckhardt Fuchs, 'Introduction, Problems of Writing World History: Western and Non-Western Experiences, 1800-2000,' in Benedikt Stuchtey and Eckhardt Fuchs, eds, Writing World History, 1800-2000. Oxford: Oxford University Press, 2003, 1-44; Philip Pomper, 'Introduction: The Theory and Practice of World History,' in World History: Ideologies, Structures, and Identities. Oxford: Blackwell, 1998, 1-17; Chakrabarty, Provincialising Europe; Vinay Lal, 'Provincializing the West: World History from the Perspective of Indian History,' in Benedikt Stuchtey and Eckhardt Fuchs, eds, Writing World History, 271-91.

9. Theodore Zeldin, France, 1848-1945, vol. 2. Oxford: Clarendon Press, 1977, 482-91. See the director of the Paris opera stating in 1831, after the July Revolution, that the opera house would be to the bourgeoisie what Versailles had been for the monarchy. Quoted in Carolyn Abbate and Roger Parker, A History of Opera: The Last 400 Years. London: Penguin, 2015, 270.

10. James H. Johnson, Listening in Paris: A Cultural History. Berkeley, CA: University of California Press, 1995; Anselm Gerhard, The Urbanization of Opera: Music Theater in Paris in the Nineteenth Century. Chicago: University of Chicago Press, 1998; Annegret Fauser and Mark Everist, eds, Music, Theater, and Cultural Transfer: Paris, 1830-1914. Chicago: University of Chicago Press, 2009; Benjamin Walton, Rossini in Restoration Paris: The Sound of Modern Life. Cambridge: Cambridge University Press, 2007; Mark Everist, Giacomo Meyerbeer and Music Drama in Nineteenth-Century Paris. Aldershot: Ashgate, 2005.

11. Mark Everist, 'The Music of Power: Parisian Opera and the Politics of Genre, 1806-1864', Journal of the American Musicological Society 67: 3 (2014): 707-8.

12. K. Ellis, 'Funding Grand Opera in Regional France: Ideologies of the Mid-Nineteenth Century,' in Rachel Cowgill, David Cooper and Clive Brown, eds, Art and Ideology in European Opera. Woodbridge: Boydell, 2010, 69; Carlotta Sorba, 'National Theatre and the Age of Revolution in Italy,' Journal of Modern Italian Studies 17: 4 (2012): 408.

13. Léon Lefebvre, Histoire Du Théatre de Lille, IV: Le Théatre Municipal, 1850-1880. Lille: Lefebvre-Ducrocq, 1902, 198.

14. Léon Lefebvre, Histoire Du Théatre de Lille, IV, 178, 220.

15. 'Eugène Bertrand,' C. E. Curinier, ed., Dictionnaire Nationale Des Contemporains, vol. 2. Paris: B. Brunel, 1899, 165.

16. Léon Lefebvre, Histoire Du Théatre de Lille., 5 vols. Lille: Lefebvre-Ducrocq, 1902; for example see under the rubric 'Chronique des Théatres de l'Étranger et mouvement des Artistes' in various editions of the weekly L'Europe Artiste.

17. See discussions of the theatre in the minutes of meetings of the Conseil Municipal de Lille. For examples of the attitudes referred to above see remarks from these councillors on the following 
dates: Rochart, 27 Feb 1889; Thibaut, 22 March 1889; Verly, 24 March 1893; Legrand, 2 June 1893; Bigo-Danel, 3 March 1893; Delesalle, 17 March 1897; Delesalle, 22 November 1907. These minutes are held in bound volumes in the $1 \mathrm{D} 2$ series in the Archives Municipales de Lille, and have recently been digitized and are available online via the Archives' website.

18. David Grayson, 'Finding a Stage for French Opera', in Mark Everist and Annegret Fauser, eds, Music, Theater, and Cultural Transfer, 133.

19. Frederick Hemmings, The Theatre Industry in Nineteenth Century France. Cambridge: Cambridge University Press, 1993, 245-6.

20. Minutes, Conseil Municipal de Lille, 18 March 1881.

21. Grayson, 'Finding a Stage for French Opera', 133.

22. Léon Lefebvre, 'La Décentralisation Théatrale à Lille', La Semaine Musicale de Lille et Du Département Du Nord, 21 February 1897, 28 February 1897, 7 March 1897.

23. Eugène Lagrillière-Beauclerc, Paul Cosseret, Lydéric. Lille: Dugardin, 1894. Extracts were also played on the local radio in 1928. 'Radio,' Le Populaire, 27 May 1928; I have been asked, when discussing Lydéric at conferences, whether parts of the opera became popularized, perhaps sung in the street or performed in taverns with new lyrics. I have not had the opportunity to investigate this question but it occurs to me that the performance on the radio might point to a tradition of local re-usage of this nature. But this is mere speculation.

24. Médéric Dufour, 'Un Musicien Du Nord: Émile Ratez', Progrès du Nord, 11 October 1931. Archives Municipales de Lille 1R/2/18.

25. A. Saint-Léger, 'La Légende de Lydéric et Des Forestiers de Flandre', Bulletin Du Commission Historique Du Département Du Nord, 26, 1904.

26. Alexandre Desrousseaux, Chansons et Pasquilles Lilloises Par Desrousseaux. Lille, 1865, 37-43; J.-B. Deletombe, 'Lydéric, Poème de M. J-B Deletombe', Mémoires de La Société Des Sciences, de L'agriculture et Des Arts de Lille, 3: 4 (1867): 469-520.

27. Anon., 'La Legende de Lydéric', La Depeche Du Nord, n. d. (loose leaf inserted into Bibliothèque Municipale de Lille copy of Lydéric).

28. Gaudefroy, Les Premiers Au Théâtre de Lille, 1893-94-1894-95, 56.

29. Peter Lamothe, 'Questions of Genre: Massenet's Les Érinnyes at the Théatre-National-Lyrique', in Everist and Fauser, eds, Music, Theater, and Cultural Transfer, 283.

30. M. Weber, 'Lydéric', Le Temps, 21 January 1895; 'Chronique Théatrale', Progrès du Nord, 11 January 1895

31. 'Lydéric,' Lille Artiste, 4: 298, 30 December 1894.

32. Gaudefroy, Les Premiers Au Théatre de Lille, 1893 - 94-1894-95, 56.

33. Louis De Fourcaud, La Salle Pleyel. Paris: Réunies, 1893, 90.

34. Harry Stopes, "'Lydéric, Sauveur de Flandres": Décentralisation Théâtrale and the Local Politics of the Opera in Lille, 1881-1896,' French History, 32: 3, (2018).

35. Manchester Central Library, Archives and Local Studies Collection, Manchester Corporation Art Gallery Committee minute books, 30 September 1897.

36. Amy Woodson-Boulton, Transformative Beauty: Art Museums in Industrial Britain. Stanford, CA: Stanford University Press, 2012, 164.

37. Manchester City Art Gallery, A Century of Collecting 1882-1892: A Guide to Manchester City Art Galleries. Manchester: City of Manchester Cultural Services, 1983, 15.

38. For example, one factory manager wrote, 'Why is it that in Manchester we have no museum illustrative of the development of decorative art, though every fourth-rate town on the Continent has such a museum? Are we so indifferent to art, or are we only waiting to be asked? With all my heart I believe that our city is only waiting to be asked!' William Burton, 'Letter', Manchester Guardian, 24 November 1909.

39. Lichtwark is the subject of a number of studies of German provincial art culture, including Jennifer Jenkins, Provincial Modernity: Local Culture and Liberal Politics in Fin-de-Siècle Hamburg. Ithaca, NY: Cornell University Press, 2003, a major influence on the thesis from which this paper is derived.

40. Art Gallery Committee, Report to the City Council of a Visit to Certain Art Galleries and Museums in Belgium, Holland and Germany and in Great Britain. Manchester: Manchester City Council, 1905.

41. Art Gallery Committee, Report to the City Council, 14.

42. Pierre-Yves Saunier, 'Taking up the Bet on Connections: A Municipal Contribution', Contemporary European History, 11: 4 (2002): 510. 
43. This friendship seems to have been of some substance: Butterworth's son states that his father was invited to Paris as Herriot's guest when the latter was Prime Minister. L. M. Angus-Butterworth, Walter Butterworth, M. A., J. P. Man of Letters. Belfield Papers, 3, 1977, 5. British Library, X.0709/1041.

44. Manchester Corporation Art Gallery Committee, 27 June 1907.

45. 'Manchester and Munich', Manchester Guardian, 27 April 1905.

46. Steve King and Geoff Timmins, Making Sense of the Industrial Revolution: English Economy and Society, 1700-1850. Manchester: Manchester University Press, 2001; Dieter Ziegler and Juliane Czierpka, 'Les Régions Motrices Dans L'histoire de L'industrialisation: Réflexions Théoriques et Méthodologiques Pour Une Histoire Économique Moderne de l'Europe', Revue Du Nord, 92: 387, 2010, 726-45; René Leboutte, 'Les Régions-Pilotes Dans Le Développement Économique de l'Europe Du Nord-Ouest', Revue Du Nord, 92: 387 (2010): 747-66.

47. Jürgen Osterhammel, The Transformation of the World: A Global History of the Nineteenth Century, trans. Patrick Camiller. Princeton, NJ: Princeton University Press, 2014, 262. 

Part III

Ideas and Commodities in Motion 

8

\section{Turning Constitutional History Upside Down: The 1820s Revolutions in the Mediterranean}

Jens Späth

\section{Introduction}

Most historians associate the European Mediterranean in the first half of the nineteenth century with backward regions at the periphery of the continent setting out for modernity. Leading contemporary politicians such as the Austrian foreign minister and future chancellor Metternich fostered such a discourse of orientalism. They moulded the once stimulating South into a part of Africa, referring to 'tyranny, superstition, poverty' and calling the consequences of these characteristics 'barbaric', 'hot-tempered' and 'violent'. ${ }^{1}$ Thus, it is hardly astonishing that classical Western historiography on the nineteenth century almost forgot about the South and, until just a few years ago, concentrated on the great powers - Great Britain, France, Prussia, Austria and Russia. ${ }^{2}$ At the Congress of Vienna in 1814-15, these five countries as a political centre divided Europe into bully pulpits, which left no space for the former great powers of Spain and Portugal, the once powerful trading centres in the Italian peninsula, or the tottering Ottoman Empire. The master narrative suggested for a long time that there existed just one European model of modernization that was valid for the entire world. Normative progress in the form of modern constitutions could come only from the liberal Western powers of Great Britain and France, which had negotiated a new social contract between monarch and people. According to the political power centre in the North, the normative centre, too, was to be found there. ${ }^{3}$ Such unilateral dichotomies of cultural and political transfers have only recently 
been questioned. ${ }^{4}$ These discourses neglect to consider that the eventual peripheral South had quite independent answers for the challenges of the post-Napoleonic era and that one cannot apply only one concept of modernization to all socio-historical contexts even within Europe. ${ }^{5}$ Such judgements have been possible also because the 1820s revolutions failed mostly after very little time and were remembered, at most, as mere episodes in the history of the nineteenth century, or were simply ignored. ${ }^{6}$

This chapter focuses on the events of the European Mediterranean between 1812 and 1823 and tries to understand Europe 'from the periphery'. ${ }^{7}$ It starts out from the assumption that in this period the Mediterranean revolutions sparked early liberalism, models of political representation and European constitutional thought in a distinctive way. With reference to Shmuel Eisenstadt's idea of 'multiple modernities', it questions the hegemonic Western way of understanding modernity, by provincializing it. ${ }^{8}$ The peripheral European South generated particular modernization projects of its own. A good example is the Spanish Constitution of 1812 that, by 1820-1, had been introduced in four countries: Spain, the Kingdom of the Two Sicilies, Portugal and Sardinia. Since this model had no major role in the Greek War of Independence against the Ottoman Empire, we will concentrate on the Iberian and Italian peninsulas. These transnational perspectives enable us not only to analyse European discourse, but also to identify transatlantic references to the Americas, as well as the global implications of a revolutionary South that includes the Indian subcontinent and reaches as far as the Philippines. ${ }^{?}$

Firstly, this chapter will outline the situation of the region under consideration between the birth of the Spanish Constitution of 1812 and the end of the Napoleonic Empire in 1815. Secondly, it focuses on the Restoration years and opens up the European perspective on the transatlantic Spanish and Portuguese colonies in Latin America, thus turning the Italian states into an 'Atlantic periphery'. ${ }^{10}$ Then my focus will turn to the revolutions of the 1820s in southern Europe. By examining the press, diplomatic sources and exchanges between liberal exiles, the chapter will outline mechanisms of cultural and intellectual exchange between shifting centres and peripheries. Finally, dealing with the legacy of the Spanish constitutional model until 1848, the chapter will conclude that accounts of the nineteenth century should not be limited to the history of independence movements, nationalism and nation states, but that they need to include issues such as political participation, individual liberties and the role of written constitutions. 


\section{2: Spain's 'most progressive' constitution}

Traditionally, the beginnings of the modern age in Europe used to be linked to the Enlightenment. Although scholars nowadays increasingly question this equation, ${ }^{11}$ a turn to more self-reflectivity in all European societies of this period is evident. Even if characterized by different junctures and characteristics, the Enlightenment gained acceptance not only among the intellectual and economic elites in France, Great Britain and the Holy Roman Empire, but also in Spain, Portugal, Naples and Sardinia. The same applies to the politics of enlightened reform and the search for alliances with other 'enlightened' monarchs. Meanwhile, before the French Revolution, hardly any monarch was willing to give up absolute sovereignty and to grant a written constitution - with the remarkable exception of the Habsburg ruler Pietro Leopoldo of Tuscany, although the European public learned of his achievements only long after his death, by $1825 .{ }^{12}$

The actual constitutional development in southern Europe was closely related to the foreign stimulus coming from Napoleon Bonaparte. ${ }^{13}$ While Piedmont was soon at the mercy of French interests, and fell victim to French imperial expansion, Naples experienced a short republican period, producing its own constitution in 1799, before being granted an authoritarian constitution based on the Statute of Bayonne under Napoleon's brother-in-law Murat. In 1815 it was granted a new constitution based on the restoration of the monarchy. In content, all of these constitutions were far removed from the state's political realities. ${ }^{14}$

As far as Portugal is concerned, the Braganza dynasty had already escaped to Brazil before the first of three invasion attempts starting in 1808. Due to British protection of Portugal, Napoleon never succeeded in conquering the country completely and in 1811 he withdrew from the western part of the Iberian peninsula. ${ }^{15}$ The Congress of Vienna recognized the Braganzas' new kingdom across the Atlantic, which was governed in personal union with the European mother country. The far bigger country on the peninsula, Spain, fell victim to the last stage of Napoleonic expansion in the Mediterranean. While the two Italian kingdoms, Piedmont-Sardinia and Naples, had to wait for independence until Napoleon's fall, Spain, which was never completely occupied, defied French rule. In the Spanish War of Independence, the country's intellectual elites, who were very unhappy with the Bourbons' timid reform policies, saw the opportunity to establish a new political order by means of a constitution. ${ }^{16}$ How could this happen? 
When the Bourbon King Charles IV and his son Ferdinand VII were quarrelling over the Spanish throne in 1808, Napoleon ordered his General Joaquin Murat to conquer the northern part of the Iberian peninsula. Once he reached this goal, Napoleon asked the two Bourbons to meet him at Bayonne in southern France. There, on 5 May, he dictated diplomas of abdication to both of them, imposed the so-called Statute of Bayonne two months later, and installed his brother Joseph as José I on the Spanish throne. Napoleon's intervention proved to be an event of unparalleled consequences in Spanish constitutional history. ${ }^{17}$ Soon, large parts of the Spanish population began to put up resistance. Local juntas made a stand against the deposition of their dynasty, and against the ongoing invasion by French troops, for two reasons: first, they supported their legitimate king, Ferdinand VII; and second, they regarded the people's fundamental right to co-decide in matters of succession as having been violated by Napoleon. Thanks to the new guerilla tactics of their army and with support from Britain, by 1813 Spain had managed to expel its French invaders. As a result of the people's enthusiastic participation in the struggle for independence, the prospects for revolutionary and liberal ideas were promising. The power vacuum that briefly prevailed after the defeat of the French opened up the opportunity to establish a new order in Spain: a constitutional monarchy. ${ }^{18}$

In the microcosm of the occupied city of Cádiz, elected deputies from the free and occupied provinces and from overseas flocked together to discuss the future of their country. Generally, about one-third of this crowd can be ascribed to the first estate, only three per cent to the nobility and approximately two-thirds to the third estate. These socially rather well-off men referred to themselves by the traditional name of the Spanish parliament: the Cortes. Since there were enough representatives from all three estates, both from the cities as well as from the provinces, the Cortes could legitimately claim to constitute an assembly of delegates that represented the entire Spanish nation in both hemispheres. ${ }^{19}$ For the first time in Spanish history they decided, against the will of the royalists, to meet in a single chamber that was constituted irrespective of class differences. The constituent Cortes declared, in their very first decree on 24 March 1810, that they represented the sovereign will of the Spanish nation and that the envisioned constitution was to be based on the principle of the separation of powers. ${ }^{20}$ Soon three groups emerged: liberals, royalists and Americans. Of these three, the liberals were by far the largest group. All groups discussed different constitutional models. ${ }^{21}$ In the end, on 19 March 1812, they promulgated a constitutional text that 
combined elements from French, American and British constitutional thought along with historically Spanish traditions. ${ }^{22}$

Two more contemporary constitutional models were in circulation in Europe at the time: the Sicilian constitution of 1812 and the French Charte constitutionnelle of 1814. Compared to these texts, the Constitution of Cádiz was by far the most complex as far as the diversity and multiplicity of theoretical influences is concerned. ${ }^{23}$ In the Sicilian case the project was based on an initiative by the British governor Lord William Bentinck, even if parliament played a central role. In France, the Charter was imposed by Louis XVIII. As a consequence, only in Spain did the nation flock together as the constituent power. Article Three declared that 'sovereignty lies essentially with the nation'; no such mention existed in the Sicilian or French texts. The progressive character of the Spanish constitution is also reflected in its reference to universal male suffrage for Spanish citizens, while suffrage in Sicily and France was restricted by census. Nowhere else was parliament more powerful than in Spain, where the single chamber enjoyed far-reaching prerogatives. The Spanish parliament's unique position was further strengthened by the fact that the king only had a suspensory veto and no right to dissolve parliament. Thus, compared to the Sicilian and the French models, the Spanish text was by far the most progressive. ${ }^{24}$ France's Charte constitutionnelle sought to balance the people's sovereignty with monarchic absolutism. As an octroi it emphasized the pre-eminence of the king, although it had to accept the essential result of the revolution that monarchical power was restricted by a constitution. The moderate Sicilian constitution, where the role of the king was weaker, has to be situated halfway between the two others. ${ }^{25}$

Among Spain's several constitutions during the first half of the nineteenth century, the Constitution of Cádiz was the most progressive. Neither the Royal Statute of 1834 nor the constitutions of 1837 and 1845 conceded similar power to parliament and nation. Only the constitution of 1869 got close to the Cádiz model, again by the exact designation of the text as the 'Democratic Constitution of the Spanish Nation' and the word-for-word copy of Article Three. However, contrary to the situation in 1869 , in 1812 and 1820 no republican ideas were on the agenda. Likewise, during the first half of the nineteenth century, 'democratic' was still considered a swear word that liberal constitutionalists did not use. Only conservatives and absolutists, who were hostile to written constitutions in principle, made frequent use of the term in order to denounce the danger of antimonarchic conspiracies and the potential of liberal constitutions for encouraging social upheaval in post-Napoleonic Europe. ${ }^{26}$ 


\section{'Restoration' in southern Europe: Old empires and new peripheries}

Historiography has characterized the years following the collapse of the Napoleonic Empire as the Restoration era. For the period from 1815 to 1830 , the term is misleading and offers no key to understanding nineteenth-century European history as a whole. ${ }^{27}$ Only in the Mediterranean and in a few German states did the monarchs who had governed before Napoleon return, and almost everywhere monarchical rule had to adapt to new conditions. ${ }^{28}$ Recent studies question the conventional dichotomy of revolution and restoration, describing the relation between the two in more nuanced ways. ${ }^{29}$ For instance, Brian Vick stresses that such bipolar schemes, referring to the period following the Congress of Vienna, are of little explanatory value. Instead, he underlines the multifaceted process by which a new international order emerged, one characterized by a multilateral European dimension. ${ }^{30}$ Similarly, new research on Spain relates the return of the Bourbons in Madrid to developments elsewhere in Europe. ${ }^{31}$ After all, the old colonial powers of Portugal and Spain remained imperial states with territories in both hemispheres although after the Napoleonic expansion and the Spanish War of Independence they struggled with their colonies' fight for independence in Latin America.

If we now look at the Congress of Vienna, and at the aims pursued by the centre (namely the European great powers) towards the periphery (i.e. southern Europe), we note a 'policy of security' that was defensive and constructive at the same time. ${ }^{32}$ Analysing the Treaty of Paris of May 1814, three agreements concerning Spain, Portugal and the Italian states have to be mentioned: the rollback of French borders to the state of 1 January 1792 Art. III); the reconfiguration of Italy into independent states (Art. VI); and the restitution of Santo Domingo to Spain (Art. VIII). ${ }^{33}$ At the Congress of Vienna there was no Italian, Portuguese or Spanish commission. In the conference proceedings of 8 June 1815, twenty articles of the fifth paragraph deal exhaustively with Italian affairs. Among the most important results were the enlargement of Sardinia to include Genoa (Art. 85-90), the Austrian expansion into northern Italy (Art. 93-5) and the return of the Habsburg secundogenitures - Habsburg-Lorraine, Habsburg d'Este and Bourbon-Parma in Modena, Massa and Carrara, Parma and Piacenza, as well as in Tuscany (Art. 98-100). Furthermore, the Spanish infanta Maria Luisa received the principality of Lucca (Art. 101-2) and the Papal State was restored 
as a stabilizing factor in the Italian peninsula (Art. 103). The Bourbon Ferdinand IV returned to his throne in Naples and ruled from now on as King Ferdinand I of the Two Sicilies (Art. 104), with Naples as the capital, turning Sicily into a peripheral position within the new kingdom. Three articles of the sixth paragraph (Art. 105-7) dealt with Portugal and its relationship to France. It settled the return of Olivenza by Spain and of French Guyana. ${ }^{34}$ Portugal was one of the signatories of both the Treaties of Paris and the Vienna Final Act, whereas Spain was so upset that its demands for Parma, Piacenza und Guastalla had been ignored that its minister plenipotentiary, Pedro Gómez de Labrador, refused to sign the Act (which King Ferdinand VII belatedly did in 1817).

In the field of European high politics, the Italian states, Portugal and Spain indeed found themselves in a peripheral situation, because they were excluded from the most important decisions made by the four victorious powers plus France, and participated in the Congress of Vienna simply as signatory powers of second rank. ${ }^{35}$ Although the independence of all southern European states was formally re-established in 1814-15, the great powers preserved considerable informal influence, southern Italy being the most evident example. Here, Vienna and King Ferdinand of the Two Sicilies agreed on a secret treaty to grant Austria the right of military intervention in case the internal conditions of the southernmost kingdom should change in a revolutionary way. ${ }^{36}$ Neither in Spain nor in Sardinia, where the Bourbon Ferdinand VII and the Savoy Victor Emanuel I re-ascended to their thrones in spring 1814, were similar arrangements to be found. Nonetheless, both states remained in the French geostrategic sphere of influence, whereas Britain, as an imperial sea power, performed a similar function in Portugal and in the Mediterranean's insular and maritime provinces - the southern Italian ones in particular. ${ }^{37}$

Turning towards Latin America, it has to be stressed that 'constitutionalism was, essentially, an Atlantic phenomenon', because both Spanish and Latin American deputies had given birth to Hispanic liberalism, which combined enlightened with Catholic elements. ${ }^{38}$ The constitution of 1812 played an important role during the first constitutional period, but a minor one in the second. Despite treating Spanish citizens as equal concerning taxation (Art. 339), its abstract ideals were hardly implemented in practical politics, neither during the years 1812-14, nor during the revolution of 1820-3. Furthermore, people of African origin in the colonies were mostly excluded from citizenship, and slavery continued to exist until the end of the nineteenth century. Thus, the colonies continued to find themselves in a peripheral position 
towards their European motherland and, starting with the Spanish War of Independence against Napoleon, most of them tried to fight for their own independence. Within the framework of this short chapter we cannot summarize the manifold regional consequences of these movements for the Spanish constitution in the colonies. It should be enough to state that even though all Hispanic revolutions started in the absence of a king, their constitutional debates and handling of the Cádiz model of 1812 were far from linear or homogeneous. ${ }^{39}$

It is remarkable that Portuguese Brazil maintained the imperial political system of the ancien regime until 1821. Unlike in the Spanish colonies, in Portuguese Brazil there were hardly any demands for an independent kingdom or for constitutional liberties; and there were no fights between republicans and royalists. This is usually explained by the transfer of the Portuguese court to Rio de Janeiro, meaning that the Braganza dynasty was present - historically a unique reversal of the traditional relationship between metropole and colony ${ }^{40}$ In other words, periphery did not mean periphery forever. This scenario implied that in contrast to the Spanish territories, in the case of the Portuguese Empire the emergence of centrifugal forces in the provinces could be avoided, creating a sense of Brazilian unity at a time when many Portuguese in the motherland felt abandoned. Contrary to most former Spanish colonies that chose a republican form of government, Brazil opted for a monarchical government in 1822 that lasted until the end of the Empire in $1889 .{ }^{41}$ Ultimately, the Atlantic region might be best defined as a huge laboratory for a variety of open-ended political experiments. ${ }^{42}$

Returning to the chapter's initial argument about the Restoration period, in the case of the Mediterranean we suggest talking about restorations in the plural, that did not follow any monolithic principle. On the one hand, monarchical legitimacy - i.e. divine rights related to the recognition of the hereditary succession from one sovereign to the next, with the approval of the international community - regained acceptance. ${ }^{43}$ On the other hand, in several cases the restoration of the former dynasties was the result of specific conditions such as Napoleon's brief return to power. Concerning the return to the more general conditions of pre-Napoleonic Europe, the answer has to be even more nuanced: while in Madrid and Turin an absolutist revival turned back the clock to pre-revolutionary times, in the Two Sicilies many administrative and judicial reforms remained in force. In addition, in all three kingdoms the Napoleonic experience had left an impact on people that could not be extinguished by one brushstroke. If we do not insist on a mere constitutional definition of restoration, but take into consideration social and 
cultural agents, it makes little sense to talk about a 'Restoration' in the singular; and nowhere in Europe do we see a general rollback to the ancien regime. ${ }^{44}$

\section{The first post-Napoleonic revolutionary wave}

It seems justified to ask whether, after Napoleon, a harmonious order of peace in Europe could be achieved without violence; or if violence was not a desired aim and an instrument to counteract violent changes. By establishing a new equilibrium at the centre of the continent, did monarchs and politicians not merely risk moving the outbreak of violence to the periphery? At least in southern Europe in 1820-1, Metternich's strategy to prevent revolutions through reform politics had failed. Furthermore, in February 1820, Charles-Ferdinand d'Artois, Duc de Berry, a potential heir to the French throne, fell victim to an antimonarchical attack. $^{45}$

In the German Confederation and in Britain, the authorities were mostly successful in avoiding uprisings and the spread of terrorist attacks. Exceptions were the assassination of the writer and diplomat (then in the Russian service) August von Kotzebue, or larger protests such as at Peterloo in 1819, or the Cato Street conspiracy in 1820, which was directed against the entire British Cabinet and may well have turned into a proper revolution.

However, after Simón Bolívar and other insurgents took advantage of the unstable situation in Europe and established independent republics in Latin America, a new cycle of revolutions began hitting Europe. In Spain, on 1 January 1820, troops meant to suppress the turmoil in the colonies, rebelled in in Cádiz. Spain was followed by the Two Sicilies, Portugal and Sardinia, as well as by the south-eastern parts of the Balkans that belonged to the Ottoman Empire. The fact that the European periphery had been defeated during the Napoleonic Wars, but now propagated liberty and constitutionalism, reveals the fragility of the arrangements undertaken by the victorious powers at Vienna.

These signs of political unrest, over a period of fifteen months, were nourished by increasing discontent over the politics of absolutist governments among large parts of the population. Social and economic factors such as the high price of bread - the result of a famine following the climatic crisis after the eruption of the Tambora in Indonesia in 1815 had particularly severe consequences for the essentially agricultural 
southern European societies. ${ }^{46}$ Similarly dramatic for public finances was Portugal's and Spain's loss of most of their transatlantic colonies, since the mother countries were used to gaining high profits from overseas. Deprived of imperial trade, they no longer knew how to handle their debts. ${ }^{47}$ In addition, the experiences of the French Revolution and of the Napoleonic era had made people aware that they had enjoyed superior forms of government before. The Spanish liberal Álvaro Flórez Estrada wrote to King Ferdinand VII from his London exile: 'Today there is no craftsman or agricultural worker who would not long for any change of government, because he recognizes that the current government has lost its entire moral strength, because it only has the power to do bad and because it is impotent and void concerning the benefit for society. 48

Liberal movements in the western hemisphere identified the societal benefits of extensive modernization associated with rationalized bureaucracies, liberalized economic activity, political participation, independent academic institutions, freedom of the press and the increase of literacy among the masses. In order to express their demand for substantial reforms, they organised their discontent in many ways. In Spain, one pronunciamiento followed another without showing results. These highly formalized coups d'état by military means envisioned the establishment of a more liberal political order. In the Italian states and Portugal, essentially military secret societies such as the Carbonari, Federati and o Sinédrio reinforced their activities. In southern Italy, the Murattiani, the former administrative and military elites of the Napoleonic period, espoused a liberal and constitutional form of government. Thus, parts of the army, first of all officers who were at the same time highly educated members of the secret societies, together with parts of the petty bourgeoisie, landowners and tradesmen, now claimed political participation. They justified their demands by reference to their strongly increased economic influence. In Sardinia, the same applied to young aristocrats. However, in all of these cases the decisive factor was the army, where liberal officers took the lead and proclaimed constitutions, while riding across the country, initially with just a few hundred men. ${ }^{49}$ According to Metternich, the idea of the army as an institution of political modernization constituted a far more fatal development than speeches in constitutional parliaments. ${ }^{50}$

No revolutions broke out in the capitals, where complacent old men were often involved in the same solidified elite circles for decades, but they did in the provinces, i.e. in the respective peripheries. This is hardly astonishing if one considers the fragmented, but essentially agrarian, social and economic structure of southern Europe. After 1815, more than two-thirds of the population still worked in the primary sector. 
Meanwhile, agriculture and the agrarian elites witnessed during that period a real boom due to the permanently increasing prices for their products. In addition, the provincial elites benefited from the end of feudalism, which brought a paradigm shift from privilege to merit. Intimately connected with the increase in power for the provincial notables was a new individualism that resulted in political demands to protect private property and civil rights. Similar to the arguments espoused by Marta Petrusewicz in the introductory section of this book, and contrary to the unbridled Manchester liberalism reigning in much of northern Europe, southern European societies opted for a slow and gradual modernization, preserving social hierarchies, traditions and local knowledge. This essentially local and regional character contributed significantly to the peacefulness of the revolutions, which were almost without violence and not directed against the ruling monarchs. The character of these movements constitutes a central argument against the stress on nationally motivated acts of violence related to 'essentially European terrorism between 1817 and 1825. ${ }^{51}$

Referring in this context to the term 'national' requires some brief remarks about the nation state as an alleged telos and a political leitmotiv during the early nineteenth century. In the case of the two old empires, Spain and Portugal, the transformation into nation states shows several peculiarities. Spain changed from a Catholic monarchy to a Catholic nation, where the legitimation of power did not simply derive from divine right but from sovereignty shared between monarch and citizens. This arrangement was guaranteed by the written constitution. ${ }^{52}$ In the Portuguese case, constitutional change was linked to the transfer of the court to Brazil..$^{53}$ In many Latin American countries a sense of national identity did not emerge before the middle of the nineteenth century. ${ }^{54}$ The same applies to Portugal and Spain, where a national consciousness only emerged in response to the dissolution of the empire. ${ }^{55}$ In the Italian case, the idea of the nation state as it emerged in 1861 was largely constructed teleologically, after unification. Sardinia, around 1820, at best envisioned the unification of northern with central Italy. The majority of the people of the Two Sicilies regarded southern Italy as their nation and responded to the Risorgimento with a peripheral sense of patriotism. Moreover, they struggled against a violent Sicilian separatism. At most they imagined an Italian confederation of states presided over by the Pope. Thus, national discourse was largely based on local and regional identities. $^{56}$

The Spanish pronunciamiento of January 1820 aimed at reinstating the Constitution of 1812 . Other constitutions were hardly discussed. The 
Charte constitutionnelle was opposed due to anti-French prejudices. The moderate liberal elites in Naples, Lisbon and Turin - foremost among them the Murattiani and young noblemen around the young intellectual Cesare Balbo - supported a constitutional model along French or British-Sicilian lines, but soon had to give way to the pressures of secret societies to accept as their model the Spanish Constitution of 1812. Following the Spanish War of Independence against Napoleon the reputation of this document had assumed almost mythical dimensions, as Balbo has pointed out: 'The Spanish Constitution was the slogan, the name, the flag around which all liberal opinions, the liberal hopes of Italy gathered together'. ${ }^{57}$

Although the revolutionary elites relied not on democratic radicalism but on legitimate dynasties in order to realize their political projects, the four monarchs on the Iberian and Italian peninsulas shared a considerable disdain for constitutional forms of government. However, we can observe important differences between them in the run-up to the proclamation of the constitution. Ferdinand VII took the lead in the constitutional movement - against his own conviction, but following the State Council - by saying: 'I swore to this constitution that you desired and I will always be its strongest supporting pillar ... Let us go on sincerely, and me first, on the constitutional path. ${ }^{58}$ His uncle in Naples, Ferdinand I, dissociated himself from the constitutional regime, by vesting his son Francis with official duties. John VI of Portugal returned to Lisbon only reluctantly and after parliament had urged him to take the oath on the constitution. After that, his son Peter - left behind in Rio de Janeiro, the 'tropical Versailles', ${ }^{59}$ - proclaimed the Empire of Brazil to be independent and became head of state. In the end, Victor Emanuel I in Turin was the only monarch to retain his anti-constitutional attitude, and he abdicated in favour of his brother Carl Felix. The Italian and Spanish monarchs reached out to the European great powers to seek the quickest possible end to constitutional government.

Taken together, there are five points which seem to confirm the peripheral situation of these southern European countries prior to the revolutions of $1820 .{ }^{60}$ Firstly, geography and topography conditioned a peripheral position at the edge of Europe, although Portugal and Spain remained transatlantic colonial powers even after the emergence of independence movements in Latin America. Secondly, in economic terms, southern Europe remained essentially agrarian and did not produce many high-quality consumer goods for export. With the increasing loss of their colonies, raw material resources and other sources for revenue collapsed. Thirdly, regarding political conditions, the formally independent countries of Portugal, Spain, Sardinia and the Two Sicilies 
became part of the informal influence spheres of the great powers France, Britain and Austria - resulting in a loss of sovereignty. Fourthly, concerning the prerequisites of an extensive modernization of society, the future did not look very rosy in view of weak governmental and administrative structures. Finally, there was their socially peripheral situation, which was due to an almost total lack of the middle classes, which explains why agrarian elites continued to play such an important role in the modernization of southern Europe.

The main problem of the period 1815-20 consisted in the fact that urgently needed administrative, infrastructural, economic, political and judicial reforms, which leading European politicians such as Metternich demanded, were only partially and reluctantly introduced. Therefore, there seemed to be no other solution than revolution to modernize society. Paying reference to a pivotal historical event such as the Spanish War of Independence, heroes such as Rafael del Riego in Spain led the southern European revolutions to a temporary success, suddenly turning Europe's periphery into a centre of change.

\section{Modernization from the periphery: The Cádiz constitution and the Mediterranean revolutions, 1820-3}

In what ways did the constitutional monarchies seek international recognition for their revolutionary path to modernization? At least three levels can be identified: first, they worked through the international press; second, they sought direct and indirect diplomatic support for their new regimes; and third, they participated in the transnational networks of secret and patriotic societies, joining other European liberals, especially in Spain and Greece, in order to support their fight for liberty, independence and constitutionalism. ${ }^{61}$

The press and public opinion in the southern European kingdoms identified numerous parallels and connections between the revolutions. Meanwhile, with regard to the revolutionary process, different countries ascribed different roles to themselves and to each other. Liberal Spain saw itself as the pioneer of the constitutional movement in the Mediterranean and stressed the revolutions' moderate character, distancing itself clearly from extreme ideas and violence: 'These are the maxims that will bring the Neapolitans security in their institutions, peace in their villages, dignity for the nation, the respect and appreciation of Europe. These are also the maxims that will guide the Portuguese to be happier and to 
be respected. ${ }^{62}$ Journalists in the Two Sicilies emphasized the Spanish Constitution's role as a model for civilized political and constitutional change, ${ }^{63}$ but also underlined the rapid success of their own revolution. ${ }^{64}$ Revolutionaries in the Kingdom of Sardinia worked towards an imminent uprising in the whole of Italy, which in the long term should lead to the unification of the entire peninsula. It was for the aim of national unification that Cesare Balbo opposed a revolutionary strategy, as well as the implementation of the Spanish Constitution of $1812 .{ }^{65}$ The Piedmontese liberals assigned themselves an essential role in the transformation of Italy and southern Europe, which presented the basis for their role on the even bigger European stage. ${ }^{66}$

Enemies of the revolutions in Europe were clearly aware of the events' international and transnational dimension. The Piedmontese consul-general in Tunis, Luigi Filippi, complained in 1822 that with their revolutionary ambitions the liberals would teach all of Europe principles such as independence, liberty and equality, thus nurturing rebellion and anarchy. The liberals' biggest offence consisted in having divided the monarchs from their loyal subjects and in having initiated reforms by way of radical revolutionary uprisings ${ }^{67}$ Many contemporaries made similar observations, underlining the principle behind all of these uprisings, 'that contagious spirit of democratic swindle which ... puts social peace at risk' ${ }^{6}{ }^{6}$ Meanwhile, they seemed unable to prove the widespread theory that these networks of European liberals worked by a perfidious plan of French agitators and diplomats to start constitutional revolutions in the European periphery, which were in turn to spread across the continent. ${ }^{69}$ The same applies to Metternich's conviction that they were fighting a well-organized, disciplined and monolithic secret society that was responsible for the revolution in Europe as a whole. ${ }^{70}$

As controversial as the press and public opinion was diplomacy. Similar to the views prevailing in Vienna, at the congresses of Troppau, Laibach and Verona the representatives of the Two Sicilies, the Duke of Campochiaro and Prince Cariati, both of them Murattiani, opposed the two legitimist representatives of Ferdinand I, Cardinal Ruffo and Prince Serra-Capriola. Contrary to the situation in 1814-15 in 1820-1 the constitutional monarchists found themselves in the position of having to defend themselves and were not received by Metternich. Most other European courts also denied the liberal Neapolitan delegates accreditation. Even if they started their duties as representatives of their government, they were often isolated or found themselves in trouble regarding the gathering of information or communication with their respective capitals, as was the case for the Neapolitan envoy Troiano Pescara in Turin, the consequence 
of direct Austrian intervention. ${ }^{71}$ Thus, foreign secretary Campochiaro had to find other public and secret channels for making Naples' voice heard in Europe. ${ }^{72}$

The liberals in northern and southern Italy received designated diplomatic support from Spanish ambassadors in both Naples and Turin, Luis de Onís and Eugenio Bardají. However, this commitment came too late, because already in Troppau the great powers had agreed on the intervention principle. On the other hand, recommendations and statements of solidarity usually remained mere lip service. ${ }^{73}$ Concerted actions by Spanish, French and Bavarian diplomats - all representatives of constitutional monarchies - to introduce liberal constitutions in the Italian states on a permanent basis remained unsuccessful. ${ }^{74}$ The Piedmontese envoys in Madrid (Antonino Brignole Sale and Vittorio Balbo Bertone di Sambuy) and Naples (Raimondo de Quesada, Earl of San Saturnino/ Clemente Solaro della Margherita) watched the events closely. They criticized the Spanish Revolution as an arbitrary act by a few thousand men directed against their monarch. In the case of the Two Sicilies they were aiming for a more restrained modification of the constitution. ${ }^{75}$ The ambassadors of the Two Sicilies in Turin and Madrid (Troiano Pescara and Andrea Coppola, Duke of Canzano) were hoping for an anti-Austrian uprising all over Italy and for open Spanish support in international circles. ${ }^{76}$

Italian and Spanish secret or patriotic societies represented the third transnational element behind these events. Alongside the huge constitutional debate in Italy and all over Europe at the time, translations of constitutions, the publication of constitutional commentaries and of constitutional catechisms contributed to the exchange of liberal ideas in Europe and beyond. The agitation among liberal exiles everywhere in Europe formed the climax of this public debate in the Mediterranean. From early 1821 onwards, Italians moved the Carboneria to Spain, where they made plans for actions at home and in 1823 fought alongside Spanish liberals against the French intervention. In addition to serving their personal interests as exiles, they thus displayed practical international solidarity. Spain received them benevolently and granted them financial aid. The Spanish integrated the Italian liberals into their constitutional army, founded new patriotic societies and supported their extensive journalistic work. ${ }^{77}$ Thanks to the help of his friend the Spanish diplomat Luis de Onís, the protagonist of the Neapolitan revolution, Guglielmo Pepe, managed to escape the death penalty and flee to Spain, where the inhabitants of Barcelona welcomed him triumphantly. ${ }^{78}$ Many Neapolitan and Piedmontese liberals received similar aid. Narciso Nada 
counted more than a thousand people, of whom most were radicals and chose Spain for exile, whereas a moderate and less compromised minority fled to France, Britain, Belgium, Switzerland, the Netherlands and other European countries. ${ }^{79}$

Most recent studies have emphasized the importance of the Italian, Spanish and Portuguese experience of exile for the development of national identity at home, as well as the influence of the different host countries on the exiles' intellectual biographies. The international and cosmopolitan background of these people, their mobility and their multilingual background, contributed significantly to the emergence of a liberal, patriotic, and to some extent republican political culture in Europe and Latin America. In particular this was the case in hotspots like London and Paris, but also on the other side of the Atlantic. ${ }^{80}$ This background also explains why a majority of these liberals did not accept the borders imposed in 1815, and why many of them thought beyond their own national background. For many of them it seemed obvious that the domestic political order could only be overcome within a bigger international context. ${ }^{81}$ When Spain as the South's last bastion of progressive constitutionalism fell in 1823 - in the two Italian states this had happened as early as 1821 - the only field of transnational activism for European liberals remained the Greek War of Independence against the Ottoman Empire. ${ }^{82}$

\section{Cádiz's legacy: The ratio of constitutional modernization between periphery and centre}

Even today, the events of the 1820s in southern Europe are - if at all described disparagingly as skirmishes, riots or revolts that seem insignificant due to their short lifespan..$^{83}$ Such assessments, however, misjudge the importance of these revolutions led by a generation of Europeans that had come of age during the years of the Napoleonic Wars. This period of constitutional government started with the first parliamentary elections based on almost universal male suffrage. In Portugal, the liberals borrowed the electoral law of the Spanish Constitution and, by February 1821, had produced a proper 'Political Constitution', while the parliament of the Two Sicilies, by January 1821, and in coordination with the king, adapted its constitution to the specific needs of the kingdom. In Portugal, the Spanish model seemed to attract interest everywhere, until the revolutionary movement had reached its goal of reforming the 
political system and of making Lisbon once more the political centre of the Portuguese Empire. Only in Sardinia, in the short time before the revolution's suppression, was no substantial constitutional change granted, though even here the liberation of the press allowed for a brief flourishing of public debate. Although the constitutional period in southern Europe lasted for only a few months or years, and was far from being free of tensions, for the liberal elites in capital cities and provincial towns democratization and parliamentarization remained central features of political debate, with the result that at the next opportunity, in the 1830s and 1840s, the protagonists of these events were prepared to stand up again for political and individual rights, and for written constitutions. ${ }^{84}$

The works of historians such as John Davis and Marta Petrusewicz confirm these views. On the one hand, they stress the continuity of institutional, judicial and economic reforms under the Bourbons before, during and after French rule. On the other hand, they question older ideas of a passive Italian South and underline the contribution to these reforms precisely by the southern intellectual and administrative elites ${ }^{85}$ For this reason, the revolutions of 1820-1 should be interpreted as an attempt to translate the controversial political legacy of the French Revolution into constitutional liberties. This would be far more than just 'the last dream of a generation', as the liberal philosopher Benedetto Croce argued. ${ }^{86}$

Only once a new type of modern constitution arrived in Europe, in the form of the revised French Charte constitutionnelle of 1830 and the Belgian Constitution of 1831, did the influence of the Cádiz model decline. These new constitutions reconciled liberalism and Catholicism, as well as the relationship between parliament and monarch. ${ }^{87}$ After a last brief intermezzo of its 1812 Constitution, even Spain introduced this new type of constitution in 1837. Meanwhile, the memory of the Spanish model in Europe lived on, for instance during reflections about a possible revival of the Constitution of the Two Sicilies during the Revolution of $1848 .{ }^{88}$ Only with this last, bigger and more effective revolutionary wave did the first liberal constitutional model of the nineteenth century begin to fall into oblivion. ${ }^{89}$

Taken together, the events of 1820-3 in southern Europe should be read as forerunners of liberal constitutional revolutions for the entire continent, happening in countries that did not pause passively at the periphery of Europe, but took the initiative for themselves. They adopted this stance while Britain and France were struggling for world domination, and within the context of a crisis of the Iberian monarchies that lasted for decades. Although Portugal and Spain had left the narrow circle of great powers, and the Italian states remained under Austrian 
domination for almost another fifty years, recent studies suggest that these Mediterranean countries did not merely stand at the edge of great power politics. ${ }^{90}$ The foreign and domestic policies of the pentarchy counteracted the revolutionary emancipation movements in the Mediterranean, while also benefiting from the inner conflicts and emerging civil wars within the revolutionary countries. Generational conflicts between older Bonapartists and younger radicals as well as anti-imperial emancipation movements further weakened the revolutions. Ultimately, the 'Vienna Settlement' survived its first test. Meanwhile, the great powers soon started to act more flexibly, as demonstrated by the fact that they intervened in Spain and in the Italian states, while standing aside in the cases of Portugal and Greece. On the one hand, the European pentarchy led by Metternich succeeded in suppressing revolutions through its conference policy, and until 1848 it prevented the formation of constituent assemblies in Spain and the Italian states. From this point of view one might describe the Congress system as an experience anticipating ideas and institutions such as the Concert of Europe, the League of Nations, the United Nations or the European Union. ${ }^{91}$ On the other hand, crushing the revolutions encouraged the use of violence, radical action and subversion in southern Europe for years to come. There were no means for peaceful conflict resolution. Europe's leading politicians failed to permanently establish any such organizations. Instead, the 'principles of 1789', which had resulted in twenty-five years of revolution and warfare, continued to guide European politics.

Coinciding with the revolutions of 1820-3, we observe a first wave of transnational liberalism that over the following decades would grow in importance. The experience of exile represents a general pattern of this generation. Consequently, this informal Liberal International, which was the direct result of the patriots' mobility for political and military purposes, became a haven of cosmopolitan as well as national ideas. With respect to recent comparative and transnational studies, I suggest sharpening the focus conceptually to discuss a specific Mediterranean liberalism of the 1820 s and 1830s.$^{92}$ It was tied together by a sense of friendship and solidarity, political kinship and empathy, the endeavour for constitutions, civil rights and parliaments. The exiles shared the experience of battles in the Iberian peninsula or Greece, and ideological bonds such as patriotism and the fight for independence and against absolutism. The liberal exiles did not want crowned heads to roll; they aimed for constitutional monarchies and parliamentary participation. The failure of the Mediterranean liberal movements contributed to the discourse of decline and degeneration of Southern societies, which in 
turn inspired the Romantic movement. Meanwhile, if we turn our gaze from the much-studied politics of the great powers to the global revolutionary South in the 1820s and 1830s, reaching from Latin America and southern Europe to Asia, we perceive 'a history of democracy and pluralism' that contrasts with the narrow view of conflicts and ruptures. ${ }^{93}$ Of course, there was no single revolution in the 1820s, which suggests that in intellectual history we have to 'privilege contexts over ideas'. ${ }^{94}$

As a consequence, it should be possible to rethink the categories of centre and periphery in the age of revolutions, the origins of political modernity in Europe, and the question of how liberty and constitutional government, as well as social and political change, could be achieved by legal means. If one accepts and takes seriously this challenge, rather surprising perspectives appear, as the example of the Mediterranean revolutions of the 1820s shows. In this constellation, from a Southern perspective, the continent suddenly resembles the image its former colonies have themselves made of Europe. Not only does eurocentrism as such appear in a different light, but also the idea of a European centre of gravity formed by Britain, France and the German states is put into question. Conventional spatial hierarchies collide here with asymmetric power relations, requiring a more differentiated analysis. At long last the voices of the losers of history emerge over the grand narratives that have traditionally been written by the great and powerful, by the victors of history.

\section{Notes}

1. Metternich, writing from Weinzierl after the outbreak of the Neapolitan revolution, 17 July 1820, in Aus Metternich's nachgelassenen Papieren, vol. 3, ed. by Richard Metternich-Winneburg. Vienna: Wilhelm Braumüller, 1881, 340; see also the quotation of the Spanish deputy José Moreno Guerra, 'De una exposición de las comisiones de agricultura y comercio', Madrid, 24 July 1820, in Diario de Sesiones de Cortes, leg. ord. 1820-1, nos. 20, 258. On orientalism see Edward Said, Orientalism. New York: Vintage, 1979; see the debate about it in Adel Iskandar and Hakem Rustom, eds, Edward Said: A Legacy of Emancipation and Representation. Berkeley, CA: University of California Press, 2010. Also of interest concerning the periphery argument is Ignacio López-Calvo, ed., One World Periphery Reads the Other: Knowing the 'Oriental' in the Americas and the Iberian Peninsula. Newcastle upon Tyne: Cambridge Scholars, 2010.

2. See Eric Hobsbawm, The Age of Revolution, 1789-1848. London: Weidenfeld \& Nicolson, 1962; or Jonathan Sperber, Revolutionary Europe, 1780-1850. Harlow: Pearson Education, 2000 .

3. This is what the classical work in the German language still confirms: see Werner Frotscher, Verfassungsgeschichte. Munich: C. H. Beck, 2016, 9-46. Also starting from the Western modernization paradigm but in a clear European perspective is Anita Prettenthaler-Ziegerhofer, Verfassungsgeschichte Europas: Vom 18. Jahrhundert bis zum Zweiten Weltkrieg. Darmstadt: Wissenschaftliche Buchgesellschaft, 2013.

4. Jean-Philippe Luis, 'Le premier constitutionalisme espagnol et la circulation des modèles politiques dans l'Europe du début du XIX ${ }^{\mathrm{e}}$ siècle', in Landry Charrier, Karine Rance and Friederike 
Spitzl-Dupic, eds, Circulations et réseaux transnationaux en Europe (XVIIIe-XXe siècles): Acteurs, pratiques, modèles. Bern: Peter Lang, 2013, 89-102 (especially 89). Also stimulating in a broader perspective is Roberto Dainotto, Europe (in Theory). Durham, NC: Duke University Press, 2007, especially chapter 5 on 'Orientalism, Mediterranean Style', 172-218.

5. See Marta Petrusewicz, 'La modernizzazione che venne dal Sud', in Jane Schneider and Peter Schneider, eds, I Sud: Conoscere, capire, cambiare. Bologna: Il Mulino, 2009, 105-28.

6. See records on 'Moti del 1820-21' in Italian online encyclopaedia: http://www.treccani.it/ enciclopedia/moti-del-1820-21_\%28Dizionario-di-Storia\%29/ [accessed 2 February 2017].

7. For a similar approach see Michel Espagne, 'Überlegungen zur Frage nach einer europäischen Geschichte. How to Write Modern European History Today? Statements to Jörn Leonhard's JMEH-Forum', Journal of Modern European History, 14:4, 2016, 465-91 (especially 465).

8. Shmuel N. Eisenstadt, 'Multiple Modernities', Daedalus 129, 2000, 1-29; on provincialization, see Dipesh Chakrabarty, Provincializing Europe: Postcolonial Thought and Historical Difference. Princeton: Princeton University Press, 2000.

9. See Christopher Bayly, 'Rammohan Roy and the Advent of Constitutional Liberalism in India, 1800-1830', Modern Intellectual History 4 (2007): 25-41.

10. Rocco W. Ronza, 'Appunti per un modello di modernizazzione politica della "periferia occidentale”: dalle Rivoluzioni atlantiche alla genesi dello Stato liberale (1760-1859)', Annali di storia moderna e contemporanea 1 (2013), pp. 73-98 (81).

11. See Olaf Asbach, ed., Europa und die Moderne im langen 18. Jahrhundert. Hannover: Wehrhahn, 2014.

12. Gerda Graf, Der Verfassungsentwurf aus dem Jahr 1787 des Granduca Pietro Leopoldo di Toscana: Edition \& Übersetzung - Das Verfassungsprojekt. Schriften zur Verfassungsgeschichte 54. Berlin: Duncker und Humblot, 1998.

13. See Michael Broers, The Napoleonic Mediterranean: Enlightenment, Revolution and Empire. London: I. B. Tauris, 2017; Ute Planert, ed., Napoleon's Empire: European Politics in Global Perspective. Basingstoke: Palgrave Macmillan, 2016.

14. Michael Broers, ed., The Napoleonic Empire in Italy, 1796-1814: Cultural Imperialism in a European Context? Basingstoke: Palgrave Macmillan, 2005.

15. Debora Gerstenberger, Gouvernementalität im Zeichen der globalen Krise: Der Transfer des portugiesischen Königshofes nach Brasilien. Cologne, Weimar, Vienna: Böhlau, 2013.

16. On Spain under Charles IV (1788-1808) until the end of the Napoleonic occupation of the Peninsula, see the exhibition catalogue Ilustración y Liberalismo 1788-1814. Madrid: Gobierno de España, Ministerio de Cultura, 2008, especially the important articles on politics, society and economics by Emilio La Parra López, Jesús Millán García-Varela and Ángel García Sanz, pp. 245-80, on liberalism and revolution by José María Portillo Valdés and on early constitutionalism by Joaquín Varela Suanzes-Carpegna, pp. 435-56.

17. On the Bayonne Statute in constitutional perspective, see Ignacio Fernández Sarasola, La primera Constitución espaola: El Estatuto de Bayona, http://www.cervantesvirtual.com/obra-visor/ la-primera-constitucin-espaola-el-estatuto-de-bayona-0/html/ [accessed 22 March 2014]. The text of the Statute can be found in the collection Quellen zur europäischen Verfassungsgeschichte im 19. Jahrhundert. Teil 1: Um 1800, edited by Peter Brandt, Martin Kirsch, Arthur Schlegelmilch, Bonn: Dietz, 2004, document numbers 8.2.2 (Spanish) and 8.2.3 (German).

18. The literature on the Spanish War of Independence is immense and has increased considerably since the occasion of its bicentenary 1808-1814. Good overviews, with advice for further reading, are available by Miguel Artola, La Guerra de la Independencia, Pozuelo de Alarcón: Espasa Calpe, 2007; Jean-René Aymes, La Guerra de la Independencia en España (1808-1814), Madrid: Siglo XXI, 2008; Antonio Moliner Prada, ed., La guerra de la Independencia en España (1808-1814), Alella: Nabla, 2007; and Joaquín Álvarez Barrientos, ed., La Guerra de la Independencia en la cultura española, Madrid: Siglo XXI, 2008.

19. Quintí Casals Bergés, 'Proceso electoral y prosopografía de los diputados de las Cortes Extraordinarias de Cádiz (1810-1813)', in Historia Constitucional, 13, 2012, 193-231.

20. Between September and December 1810 the assembly did not yet have access to stenographs, which is why only summaries of the debates exist. However, the subsequent parliamentary work is testified extensively in several thousand pages in the Diario de Sesiones.

21. Joaquín Varela Suanzes-Carpegna, La teoría del estado en los orígenes del constitucionalismo hispánico. Madrid: Centro de Estudios Políticos y Constitucionales, 1983, 5-17; Joaquín Varela Suanzes-Carpegna, 'Los modelos constitucionales en las Cortes de Cádiz', in François-Xavier Guerra, ed., Revoluciones hispánicas: independencias americanas y liberalismo español. Madrid: 
Complutense, 1995, 243-68; Francisco Tomás y Valiente, 'Genesis de la Constitución de 1812', in Anuario de Historia del Derecho Español, 1995, 15-58.

22. Carmen García Monerris, 'El debate preconstitucional', in Emilio La Parra and Germán Ramírez Aledon, eds, El primer liberalismo: España y Europa, una perspectiva comparada. Valencia: Biblioteca Valenciana, 2003, 55. Since Warren E. Diem ('Las fuentes de la Constitución de Cádiz', in María Isabel Arriazu, María Cristina Diz-Lois and Cristina Torra, eds, Estudios sobre Cortes de Cádiz. Pamplona: Universidad de Navarra, 1967, 351-486) has compared the text of the Spanish Constitution thoroughly with the French constitutions of 1791, 1793 and 1795, a great correspondence with the French precursors is evident. See also Jean-René Aymes, 'Le débat idéologico-historiographique autour des origines françaises du libéralisme espagnol: Cortes de Cadix et Constitution de 1812', Historia Constitucional, 4, 2003, 45-102.

23. Andreas Timmermann, Die 'Gemäßigte Monarchie' in der Verfassung von Cadiz (1812) und das frühe liberale Verfassungsdenken in Spanien. Münster: Aschendorff, 2007, 383.

24. On monarchical constitutionalism in the nineteenth century, see Martin Kirsch, Monarch und Parlament im 19. Jahrhundert: Der monarchische Konstitutionalismus als europäischer Verfassungstyp - Frankreich im Vergleich. Göttingen: Vandenhoeck \& Ruprecht, 1999.

25. On similarities and differences among the three constitutions, see Jens Späth, Revolution in Europa 1820-23: Verfassung und Verfassungskultur in den Königreichen Spanien, beider Sizilien und Sardinien-Piemont. Cologne: SH-Verlag 2012, 69-104.

26. See e. g. Karl Ludwig von Haller, Ueber die Constitution der Spanischen Cortes, Winterthur, 1820, repr. 1970; and two foreign book reviews, reported in the Spanish liberal journal El Universal. Observador español, 48, 1820, 3.

27. See Reinhart Koselleck, 'Revolution: Rebellion, Aufruhr, Bürgerkrieg', in Otto Brunner, Werner Conze and Reinhart Koselleck, eds, Geschichtliche Grundbegriffe: Historisches Lexikon zur politisch-sozialen Sprache in Deutschland, vol. 5. Stuttgart: Klett-Cotta, 1984, 756; Reinhart Koselleck, 'Die Restauration und ihre Ereigniszusammenhänge 1815-1830', in Louis Bergeron, François Furet and Reinhart Koselleck, eds, Das Zeitalter der europäischen Revolutionen 1780-1848. Frankfurt: Fischer, 1969, 199-229. See also Volker Sellin, Das Jahrhundert der Restaurationen, 1814 bis 1906. Munich: Oldenbourg, 2014. Nowadays the term 'restoration' is frequently used in the plural: see Jean-Claude Caron and Jean-Philippe Luis, eds, Rien appris, rien oublié? Les Restaurations dans l'Europe postnapoléonienne (1814-1830). Rennes: Presses Universitaires de Rennes, 2015.

28. See in particular Andreas Fahrmeir, Europa zwischen Restauration, Reform und Revolution 1815-1850. Munich: Oldenbourg, 2012, 2; Dieter Langewiesche, Die Monarchie im Jahrhundert Europas: Selbstbehauptung durch Wandel im 19. Jahrhundert. Schriften der Philosophisch-historischen Klasse der Heidelberger Akademie der Wissenschaften, vol. 50. Heidelberg: Universitätsverlag, 2013. For further reading see Werner Daum, Verfassungsstruktur der zentralen staatlichen Ebene, in Peter Brandt et al., eds, Handbuch der europäischen Verfassungsgeschichte im 19. Jahrhundert, vol. 2: 1815-1847. Bonn: Dietz, 2012, 68, n. 148.

29. See e. g. Anna Karla, Revolution als Zeitgeschichte: Memoiren der Französischen Revolution in der Restaurationszeit. Göttingen: Vandenhoeck \& Ruprecht, 2014.

30. Brian E. Vick, The Congress of Vienna: Power and Politics after Napoleon. Cambridge, MA: Harvard University Press, 2014, 324.

31. See Christiana Brennecke, ¿De ejemplo a 'mancha' de Europa? La Guerra de Independenica española y sus efectos sobre la imagen oficial de España durante el Congreso de Viena (1814-1815). Madrid: Doce Calles, 2010; Pedro Rújula, 'El mito contrarrevolucionario de la "Restauración", in Pasado y Memoria: Revista de Historia Contemporanea, 13, 2014, 79-94; Juan Luis Simal, "'Strange Means of Governing": The Politics of the Spanish Restoration in European Perspective (1813-1820)', Journal of Modern European History, 15 (2017): 197-220.

32. Wolfram Siemann, Metternich, Stratege und Visionär: Eine Biographie. Munich: C. H. Beck, $2016,607 \mathrm{f}$.

33. Le Comte d'Angeberg, ed., Congrès de Vienne et les traités de 1815, vol. 1: Négociations de 1813 et de 1814 jusqu'à l'ouverture du Congrès de Vienne. Paris: Amyot, 1863, 161-76.

34. See the Vienna Congress Act in Johann Ludwig Klüber, Acten des Wiener Kongresses, in den Jahren 1814 und 1815, vol. 6. Erlangen: Palm, 1836, 19-96.

35. On the actors and the rules of the game, see Heinz Duchhardt, Der Wiener Kongress: Die Neugestaltung Europas 1814/15. Munich: C. H. Beck, 2013. 
36. See the second secret additional article of the treaty from 12 June, in Recueil des traités conventions et actes diplomatiques concernant l'Autriche et l'Italie. Paris: Amyot, 1859, 200-3.

37. See Robert Holland, Blue-Water Empire: The British in the Mediterranean since 1800. London: Penguin, 2012, 26-67.

38. Scott Eastman and Natalia Sobrevilla Perea, 'Introduction', in Scott Eastman and Natalia Sobrevilla Perea, eds, The Rise of Constitutional Government in the Iberian Atlantic World: The Impact of the Cádiz Constitution of 1812. Tuscaloosa: University of Alabama Press, 2015, 4.

39. See François-Xavier Guerra, Modernidad y independencias: Ensayos sobre las revoluciones hispánicas. Madrid: Mapfre, 1992; José María Portillo Valdés, Crisis atlántica: Autonomía e independencia en las crisis de la monarquía hispana. Madrid: Marcial Pons, 2006; Ivana Frasquet and Andréa Slemian, eds, De las independencias iberoamericanas a los estados nacionales (1810-1850): 200 años de historia Estudios AHILA de Historia Latinoamericana, vol. 6. Madrid and Frankfurt: Vervuert, 2009.

40. Manfred Kossock, 'Der iberische Revolutionszyklus 1789-1830: Bemerkungen zu einem Thema der vergleichenden Revolutionsgeschichte', in Manfred Kossock: Ausgewählte Schriften ed. by Matthias Middell, vol. 2. Leipzig: Leipziger Universitätsverlag, 2000, 1-19.

41. Even slavery was abolished only by 1888. See Gerstenberger, Gouvernementalität, 23.

42. Jeremy Adelman, Sovereignty and Revolution in the Iberian Atlantic. Princeton and Oxford: Princeton University Press, 2006, 7-12.

43. See in contrast with the principle of parliamentary representation, Wolfram Siemann, Metternich: Staatsmann zwischen Restauration und Moderne. Munich: C. H. Beck, 2010, 59-62.

44. On France, see Francis Démier, La France de la Restauration (1814-1830): L'impossible retour du passé. Paris: Gallimard, 2012.

45. See Gilles Malandain, 'La conspiration solitaire d'un ouvrier théophilantrope: Louvel et l'assassinat du duc de Berry en 1820', Revue Historique 302 (2000): 367-93.

46. See Wolfgang Behringer, Tambora und das Jahr ohne Sommer: Wie ein Vulkan die Welt in die Krise stürzte. Munich: C. H. Beck, 2015.

47. A good overview of the different national paths to independence is Ivana Frasquet and Andréa Slemian, eds, De las independencias iberoamericanas a los estados nacionales..

48. Representación hecha á S. M. C. el Señor D. Fernando VII en defensa de las Cortes por Don Alvaro Florez Estrada, Madrid, 1820 [written in London, 8 October 1818], p. $176 \mathrm{f}$.

49. See Richard Stites, The Four Horsemen: Riding to Liberty in Post-Napoleonic Europe. Oxford: Oxford University Press, 2014.

50. See a letter by Metternich of 7 April 1820, quoted in: Luigi Mascilli Migliorini, Metternich: L'artefice dell'Europa nata dal Congresso di Vienna. Rome: Salerno, 2014, 176.

51. Siemann, Metternich, 647.

52. Fundamental on this is José María Portillo Valdés, Revolución de nación: Orígenes de la cultura constitucional en España, 1780-1812. Madrid: Boletín Oficial del Estado, 2000; see also a concise summary by José María Portillo Valdés, ‘De la monarquía católica a la nación de los católicos', in Manuel Suárez Cortina, ed., El liberalismo español: Historia y Política, 17 (2007): 17-35.

53. See Gerstenberger, Gouvernementalität, esp. 98-124.

54. Gerstenberger, Gouvernementalität, $21 \mathrm{f}$.

55. Adelman, Sovereignty, 219.

56. See Jens Späth, 'Das Risorgimento: Revolution, Krieg und Nation in Italien', in: Ewald Frie and Ute Planert, eds, Revolution, Krieg und die Geburt von Staat und Nation: Festschrift zum 70. Geburtstag von Dieter Langewiesche. Tübingen: Mohr Siebeck, 2016, 83-104.

57. 'Autobiografia di Cesare Balbo', in: Della vita e degli scritti del conte Cesare Balbo: Rimembranze di Ercole Ricotti, con documenti inediti. Florence: Le Monnier, 1856, 372.

58. See Ferdinand's manifesto in Brandt, ed., Quellen, Doc. No. 10.2.3.

59. See Kirsten Schultz, Tropical Versailles: Empire, Monarchy, and the Portuguese Royal Court in Rio de Janeiro, 1808-1821. New York: Routledge, 2001.

60. Based on Marta Petrusewicz, 'La modernizzazione che venne dal Sud', in Jane Schneider and Peter Schneider, eds, I Sud, 105-28 (especially 114 f.).

61. See Späth, Revolution in Europa, 335-99; Maurizio Isabella, Risorgimento in Exile: Emigrés and the Liberal International in the Post-Napoleonic Era. Oxford: Oxford University Press, 2009.

62. Mercurio histórico y político, vol. 3, September 1820, 9.

63. Pietro Colletta, Storia del Reame di Napoli dal 1734 al 1825: Revisione sugli autografi, introduzione e note di Nino Cortese, vol. 3. Naples: Libr. Scient. Ed., 1951, $117 \mathrm{f}$. 
64. L'Amico della Costituzione, no. 8, 24 July 1820, 'Parallelo della rivoluzione di Spagna e della Napolitana', $3 \mathrm{f}$.

65. Cesare Balbo, 'Dello stato attuale del Piemonte', 17 January 1821, in Eugenio Passamonti, Alessandro Luzio and Mario Zucchi, eds, La rivoluzione piemontese dell'anno 1821: Nuovi documenti. Turin: Bocca, 1926, 308.

66. Cenno politico sul Piemonte del 24 Marzo 1821, 7.

67. Luigi Filippi, Du Piémont sur la fin du 1821 par le Chevalier ... Consul Général de S. M. (1794-1834), Luigi Firpo, C. G. a Tunisi. Turin: Imprimerie Royale, 1822, 32-34 and $61 \mathrm{f}$.

68. Archivio di Stato di Napoli, Archivio Borbone, fasc. 276, 'Cenno critico sulle conclusioni del Sig. Gaetano Brundisino Procuratore Generale Sostituto della G. C. Speciale di Napoli nella causa detta di Monteforte circa i vantaggi recati nel governativo, e nell'amministrativo dal Ministero Napoletano del Quinquennio'. Epistola, 5 (7).

69. Alphonse de Beauchamp, Histoire de la révolution du Piémont, et de ses rapports avec les autres parties de l'Italie et avec la France. Paris: Michaud, 1821, 30.

70. Mark Jarrett, The Congress of Vienna and its Legacy: War and Great Power Diplomacy after Napoleon. London: I. B. Tauris, 2013, 356; Siemann, Metternich, 654-656, 676 f., 694 f. See also Adam Zamoyski, Phantom Terror: The Threat of Revolution and the Repression of Liberty, 1789-1848. London: Collins, 2014.

71. See Annibale Alberti, ed., Atti del Parlamento delle Due Sicilie, 1820-1821, vol. 5/1. Bologna: Forni, 1931, no. 92, Pescara a Campochiaro, Torino, 22 novembre 1820, 170.

72. See Werner Daum, Oszillationen des Gemeingeistes: Öffentlichkeit, Buchhandel und Kommunikation in der Revolution des Königreichs beider Sizilien 1820-21. Cologne: SH-Verlag, 2005, 363-76.

73. On Spain's diplomatic support for Naples, see Giorgio Spini, Mito e realtà della Spagna nelle rivoluzioni italiane del 1820-21. Rome: Perrella, 1950, 45-51.

74. See Spini, Mito e realtà, $66 \mathrm{f}$, and Bayerisches Hauptstaatsarchiv München, Abtlg. II, Geheimes Staatsarchiv, Ministerium des Auswärtigen, Fasz. 2876, Sardinien, n. 28: Seyboldtsdorff to Rechberg, Turin, 21 October 1820.

75. Archivio di Stato di Torino, Lettere Ministri, Serie Diplomatiche: Spagna, Mazzo 102, no. 58: Annèxe à la Dépêche de M. le Marquis Brignole Sale, du 7. fevrier 1820; also, Mazzo 45, no. 433: Solaro della Margherita to S. Marzano, Naples, 19 January 1821.

76. Alberti, ed., Atti, vol. 5/1, no. 119, Pescara to Campochiaro, Turin, 4 December 1820, 195 f.; also no. 126, Canzano to Campochiaro, Madrid, 7 December 1820, $200 \mathrm{f}$.

77. See Späth, Revolution in Europa, 374-381; Pierre-Marie Delpu, 'Fraternités libérales et insurrections nationales: Naples et l'Espagne, 1820-1821', Revue d'histoire du XIX'. siècle, 49 (2014): 195-213.

78. On the friendly relationship between Onís and Pepe, see the two letters from Pepe to Onís, one without place and date, the other from Aquila, 24 February 1821, in Spini, Mito e realtá, Doc. V and XIV, 119, $135 \mathrm{f}$. On the welcome for Pepe and the greeting message of the Cortes deputies of 2 May 1821, see Ruggero Moscati, ed., Guglielmo Pepe (1797-1831), vol. 1. Rome: Vittoriano, 1938, 228, 254.

79. On the numbers of refugees, see Narciso Nada, 'Il destino degli sconfitti del 1821', in Alfredo Mango, ed., L'età della restaurazione in Piemonte e i moti del 1821. Savigliano: L'Artistica, 1992, $47 \mathrm{f}$. Agostino Bistarelli, who followed the traces of 850 Italian emigrants in as much detail as possible, confirmed these findings: Agostino Bistarelli, Gli esuli del Risorgimento. Bologna: Il Mulino, 2011; Ester De Fort, 'Da terra di persecuzioni a terra di asilo: Il Piemonte e l'emigrazione politica della rivoluzione del 1821 al Quarantotto', in Frédéric Ieva, ed., Il Piemonte risorgimentale nel periodo preunitario. Rome: Viella, 2015, 65-81. On other countries, see Salvatore Carbone, Fonti per la storia del Risorgimento italiano negli archivi nazionali di Parigi: I rifugiati italiani in Francia (1815-1830). Rome: Istituto per la storia del Risorgimento italiano, 1962; Donato Scioscioli, Il dramma del Risorgimento sulle vie dell'esilio. Profili, trame e rivelazioni dei proscritti del Belgio su documenti inediti dei più grandi archivi d'Europa, 3 vols. Rome: Signorelli, 1937-59; Mario Battistini, Esuli Italiani in Belgio (1815-1861). Florence: Brunetti, 1968; Anton van de Sande and Hans de Valk, 'Italian Refugees in the Netherlands during the Restoration 1815-1830', in L'émigration politique en Europe aux XIXe et XXe siècles. Rome: École Française de Rome, 1991, 191-204.

80. See Maurizio Isabella, Risorgimento in Exile; Christiana Brennecke, Von Cádiz nach London: Spanischer Liberalismus im Spannungsfeld von nationaler Selbstbestimmung, Internationalität und Exil (1820-33). Göttingen: Vandenhoeck \& Ruprecht, 2010; Juan Luis Simal, Emigrados: 
España y el exilio internacional, 1814-1834. Madrid: Centro de Estudios Políticos y Constitucionales, 2012; Grégoire Bron, 'Il Mediterraneo dei Portoghesi all'inizio del XIX ${ }^{\circ}$ secolo: Diplomazia e internazionalismo liberale, 1808-1835', Daedalus: Quaderni di Storia e Scienze sociali, 5, 2014, 119-142, URL: http://www.unical.it/portale/portalmedia/2015-01/Daedalus_5_2014_ 2DEF.pdf [accessed 7 March 2017].

81. See Irene Castells y Oliván, 'Le libéralisme insurrectionnel espagnol (1814-1830)', Annales historiques de la Révolution française, 336 (2004): 230-2.

82. See Gianni Korinthios, I liberali napoletani e la Rivoluzione greca (1821-1830). Naples: Officina Tipografica, 1990.

83. See an Italian online encyclopaedia such as http://www.treccani.it/enciclopedia/moti-del1820-21_\%28Dizionario-di-Storia\%29/[accessed 7 March 2017].

84. The Neapolitan General Guglielmo Pepe, for example, played a leading role in the revolutions of 1799, 1820 and 1848; see Luca Manfredi, L'uomo delle tre rivoluzioni: Vita e pensiero del generale Guglielmo Pepe. Foggia: Bastogi, 2009.

85. John A. Davis, Naples and Napoleon: Southern Italy and the European Revolutions, 1780-1860. Oxford: Oxford University Press, 2006. See also the chapter by Marta Petrusewicz in this volume.

86. Benedetto Croce, Storia del Regno di Napoli. Bari: Laterza, 1966, 220.

87. See e.g. the Belgian Félicité de La Mennais, or Lamennais, who collaborated actively in the building of a liberal Catholic International: Michael Burleigh, Irdische Mächte, göttliches Heil: Die Geschichte des Kampfes zwischen Politik und Religion von der Französischen Revolution bis in die Gegenwart. Munich: Deutsche Verlags-Anstalt, 2008, 183-90.

88. See Kerstin Singer, Konstitutionalismus auf Italienisch: Italiens politische und soziale Führungsschichten und die oktroyierten Verfassungen von 1848. Tübingen: Niemeyer, 2008. More recently, Axel Körner, America in Italy: The United States in the Political Thought and Imagination of the Risorgimento, 1763-1865. Princeton: Princeton University Press, 2017, 114-21 and 146-60.

89. John A. Davis, 'The Spanish Constitution of 1812 and the Mediterranean Revolutions (1820-1825)', Bulletin for Spanish and Portuguese Historical Studies, 37 (2012): https://doi. org/10.26431/0739-182X.1132.

90. On the Italian Peninsula and the Alpine area, see Brigitte Mazohl, Karin Schneider and Eva-Maria Werner, eds, Am Rande der großen Politik: Italien und der Alpenraum beim Wiener Kongress. Innsbruck: Innsbruck University Press, 2017.

91. Mark Jarrett, The Congress of Vienna, 369.

92. Maurizio Isabella and Konstantina Zanou, eds, Mediterranean Diasporas: Politics and Ideas in the Long Nineteenth Century. London: Bloomsbury Academic, 2016.

93. Eastman and Perea, eds, The Rise of Constitutional Government in the Iberian Atlantic World, 13.

94. Roberto Breña, 'The Emancipation Process in New Spain and the Cádiz Constitution: New Historiographical Paths Regarding the Revoluciones Hispánicas', in: Eastman and Perea, eds, The Rise of Constitutional Government in the Iberian Atlantic World, 58. 


\section{9 \\ The Cosmopolitan Morphology of the National Discourse: Italy as a European Centre of Intellectual Modernity}

Alessandro de Arcangelis

\section{Introduction}

The idea of Europe has always been a prominent topic of reflection for Italian authors. Dante Alighieri, in the Paradiso of his Divina Commedia, highlighted how Europa took upon herself the burden of bringing her peoples together under the banner of Christianity, ${ }^{1}$ a view appearing, with even greater force, in De Monarchia. ${ }^{2}$ Already in the fourteenth century, the identification of the geographical boundaries of the continent went hand in hand with reflections on the coexistence and, often, the unity of its peoples. Later on, the Protestant Reformation, political fragmentation and the division of Europe into nation states challenged views depicting Europe as a unitary, organic entity. Federico Chabod, author of the Storia dell'idea di Europa, reminds us of the clash between cosmopolitan ideals and the genesis of national unification projects, suggesting that the eighteenth and nineteenth centuries revealed the emergence of significant asymmetries among the European nations, concerning their engagement with the idea of Europe. ${ }^{3}$ Similarly, Benedetto Croce, who published Storia d'Europa nel secolo decimonono in 1932, provided a sharp analysis of the Risorgimento as an age of nationalisms, pointing out that these thwarted, if not completely defeated, cosmopolitan enthusiasms. $^{4}$

Croce's argument, initially formulated in the immediate aftermath of World War I, is powerful and accurate in its simplicity: the nineteenth 
century, especially after the Restoration, witnessed the proliferation of various, often conflicting, worldviews and political doctrines, most notably clericalism, monarchic absolutism, democratic ideals and communism. These ideals, appearing to different extents in the various European countries, being so closely tied with the articulation of a national and nationalist discourse, called into question people's belief in the cultural unity and, possibly, political homogeneity of Europe.

While Croce saw the Risorgimento as characterized by a tension between nationalisms and the European ideal, Gramsci proposed a different interpretation, focused on how foreign ideas and events, most notably the French Revolution, had an impact on the process of Italian unification: 'the origin of the Risorgimento', he claimed in his Quaderni dal carcere, 'namely the formation process of the conditions and the international relations allowing Italy to unite itself as a nation ... should not be searched in this or that concrete event taking place on a given date, but in the very historical transformation process of the European system,. ${ }^{5}$ Gramsci's statement was exceptionally significant: on the one hand, it cemented the idea of the Italian Risorgimento as a transnational, i.e. European, phenomenon, encouraging the study of this period so as to take into account the interplay of numerous endogenous and external factors; on the other hand, it hinted at the possibility of challenging the tension between nationalism and European ideals by establishing that the quest for the articulation of an Italian national identity was intimately connected with the negotiation of the country's position in the life of modern European nations. ${ }^{6}$ An approach of this kind inevitably contributed to the systematic rethinking of the asymmetrical relation between Italy and Europe, eroding notions of social and cultural backwardness and fully exploring an ideal of a unified Italy as a centre of European modernity.

Scholarship on the Risorgimento has, in recent years, contributed to an understanding of this period that goes beyond the mere analysis of political and socio-economic conditions, drawing attention to the specific, context-bound outillage mental, namely the constellation of discursive practices notionally belonging to the wider cultural and philosophical spheres, reflecting inclinations and concerns of the local intellectual landscape. In consequence, challenging the asymmetry between Europe and Italy entails the need to investigate the presence of a cosmopolitan sensitivity not only in Italian political thought, but also - and perhaps more importantly - in the broader cultural debates and philosophical attitudes of the decades preceding the unification. In short, the rethinking of the asymmetrical relation between Italy and Europe in the 
nineteenth century has to begin with a more compelling understanding of their encounter: one that is focused on the transnational morphology of the unitary discourse.

\section{Italy and Europe: An asymmetrical encounter}

One may wonder why the relationship between Italy and Europe in the nineteenth century could be deemed 'asymmetrical'. This can be illustrated by hard data: according to at least one interpretive model of the Risorgimento, namely one that engages primarily with socio-economic indicators, Italy was undoubtedly the laggard of Europe. Often erroneously attributed to Massimo D'Azeglio, the famous statement highlighting the need to 'make the Italians' after Italy had been 'made' after 1861, captured the nature of the challenges the new government was called to address, as it famously reflected the social ills and divisions of the period. Illiteracy amounted to a dramatic 75 per cent, and inhabitants of the South still referred to their northern neighbours as forestieri. This is striking if one compares these numbers with Britain, where the Victorian 'obsession' with education had boosted literacy rates to 75.4 per cent for men and 65.3 per cent for women in $1861 .^{7}$ On the eve of the Franco-Prussian war, thanks to the efforts to promote mass literacy, 77 per cent of French men and 67 per cent of French women were able to read and write, ${ }^{8}$ with the gender gap being fully closed in the following years. Moreover, when Germany was unified in 1871, the literacy rate of the population amounted to 88 per cent. ${ }^{9}$

In 1861, only 2 per cent of the Italian population had a right to vote: crippled by a debt of 2.5 billion lire, Italy's wealth and political organization did not match those of other European nations. In the same years, Victorian Britain was enjoying economic prosperity and was about to approve the 1867 Reform Act, doubling the size of the electorate from one to two million people. The average income of Italian citizens was half that of their British contemporaries and a third of the French. Infrastructure, especially in the south of the peninsula, was scarce: in 1861, Italy's railway system extended for 2,400 kilometres, while the Austrian Empire's exceeded 3,000 kilometres, France's 9,000 kilometres, Germany's 11,000 kilometres and Britain's 14,600 kilometres.$^{10}$ Despite Italy's advantageous geographical position, it suffered from severe insufficiencies in maritime transport, with the French able to move twice and Britain eight times the tonnage of the Italian fleet. Energy production was problematic, too: while industrialized Britain could rely on the production of 85 million 
tonnes of coal a year and Germany of 18.7 million, Italy produced a meagre 34,000 tonnes.

The economic problems of the unified state were exacerbated by the historical divide between the north and the south of the peninsula, thematized as the questione meridionale by the inquiries led in the $1870 \mathrm{~s}$ by Leopoldo Franchetti and Sydney Sonnino. Central to these studies was the identification of a dichotomy between North and South with regards to industrial development: in the Mezzogiorno, for instance, a remarkable lack of industry prior to unification reflected an extensive reliance upon proto-industrial production and agriculture; moreover, while the North had been receptive to technological innovations introduced in the context of the Napoleonic Wars, the South retained a systemic organization that resembled feudal structures. ${ }^{11}$ Production in the Kingdom of the Two Sicilies was largely geared towards domestic consumption and this, together with the exorbitant trade tariffs imposed by the Bourbon monarchy, resulted in a significant separation between northern and southern markets. Indeed this lack of homogeneity reflected profound structural differences: southern markets were poorly structured and very unassuming in their size, and so could not represent a viable destination for the manufacturing goods produced in the North. Similarly, agricultural produce from the South, most notably oil, wine and citrus fruit, was either too expensive for the relatively modest markets of Central Italy and of the North, or else its distribution was thwarted by competition from analogous goods produced in loco..$^{12}$ In short, when Italy was unified in 1861, cultural cohesion among Italians had not yet reached its maturity and a proper Italian economy, connecting all regions of the peninsula, was yet to be born. ${ }^{13}$ With powers like Britain, France and Germany leading Europe to an experience of modernity marked by technological progress, literacy and economic prosperity, Italy had the status of a periphery.

The nineteenth century witnessed the emergence of the concept of nation as the central subject of political life. The tension between national drives and the idea of a European order was particularly visible in political projects and philosophical speculation. One of the leading advocates of unification during the first half of the century, Gian Domenico Romagnosi, demonstrated a remarkable sensitivity for the encounter of national and continental interests, positing, however, that the two were not necessarily antithetical. His posthumously published Scienza delle costituzioni spoke extensively of the 'reciprocal' influence of European nations, a phenomenon deemed to be 'unceasing' and defining the continent since the Roman Empire. ${ }^{14}$ Nations, Romagnosi argued, ought to pursue independence and unity to become part of a 'great European 
family': not a fully fledged confederation of states but a system of mutual enrichment and peaceful cooperation. ${ }^{15}$

Romagnosi's most notable pupil, Carlo Cattaneo, one of the most active proponents of a republican constitution for a unified Italy, reprised his mentor's vision of a cohesive Europe, making it overtly political. A strong critic of any nationalist inclination, Cattaneo spoke of the much-debated notion of a 'United States of Europe', a federal institution aiming at preserving the 'inner and external peace, ensuring the uniformity of the monetary system and spreading ideals' ${ }^{16}$ This project was deemed unavoidable, due to the historical interconnectedness of Europe and to the nations' tendency toward 'a commonality of travels, commerce, science and laws'. ${ }^{17}$ Consequently, Cattaneo proposed the institution of yearly congresses, where scholars from various regions of the continent could come together and discuss matters of commerce, agriculture, geography and industry. For the author, a famous believer in the civic and socio-economic uses of scientific knowledge, the vision of the United States of Europe would serve a double purpose: on the one hand, it would enable the solid establishment of peace; on the other, it would contribute to the strengthening of Italy's own political and cultural identity, a process fundamentally defined by a cultural and historical relationship, as well as the awareness of Europe qua geopolitical space, which Italy belonged to and continuously engaged with. ${ }^{18}$

The idea of Europe also permeated the thought of one of the figureheads of the unification, Giuseppe Mazzini. Largely informed by the desire to foster European support for the cause of Italian unification, Mazzini's reflections on a continental confederation emphasized the need to actively educate people about European ideas and values, in contrast to Romagnosi and Cattaneo's reliance on notions of the historical interconnectedness of the continent and faith in progress. In this sense, Mazzini's calls for the articulation of a European identity entailed the need for the voluntary and deliberate action of the various states, whom he urged to educate, via a programme hovering between politics and pedagogy, the youth on the grand ideals of the federation. In consequence, Mazzini was fundamentally hostile to any attempt to unify Europe via military action, such as Napoleon's campaigns, or via formal unions among leaders, such as the making of the Holy Alliance by Austria, Prussia and Russia in 1815. Crucially, while a precise characterization of his European project remained rather nebulous throughout all his writings, there is little doubt that Mazzini's political thought was animated by the desire to amalgamate local sovereignty with a wider transnational sensitivity. Consequently, he established the Giovane Italia in 1831 and 
the Giovane Europa in 1834, whose primary goal was to bring together the European people who aspired to national unity as a means to spread the values of European democracy and peace.

It can already be seen, at this point, how the idea of Europe was prominent in nineteenth-century Italian political thought, but, while a significant number of authors were drawn towards a cosmopolitan dimension of politics, others highlighted the utopian character of this vision. What united these viewpoints was that they all acknowledged the asymmetries among European nations, whose peaceful and democratic coexistence was thus inevitably threatened: while firmly believing that some form of engagement among European people was one of the defining characteristics of the Western world, Giuseppe Ferrari admitted that, following the Revolution and the Napoleonic experience, France had imposed itself as the leading power in the continent, and was destined to act as a guide to all other nations. ${ }^{19}$ Camillo Benso, Count of Cavour was, already in the 1820s, profoundly hostile to the establishment of European institutions. In his analysis, this would only be possible if no state had any comparative advantage over others, whether in an economic, political or cultural sense. In the nineteenth century, his argument continued, the implementation of a European project would give the strongest powers of the continent carte blanche to interfere with both the foreign and domestic policies of the others.

More examples of sensitivity to the asymmetrical encounter between Italy and Europe can be found in Cesare Balbo's 1844 text Delle speranze d'Italia, in which he plotted the difficult path towards Italian national unity against the wider context of European politics and society. His analysis highlights the idiosyncrasies of the country's production and employment rates, military expenditure, geography and government, drawing attention to their relative backwardness vis-à-vis other continental powers. ${ }^{20}$ This, in turn, would make any sort of agreement or alliance among European powers boil down to an entente of the stronger ones, sharing common political and commercial interests. Consequently, despite an awareness of the debate connected with a project of European scope, Balbo urged his readers to direct their efforts to the pursuit of national unification alone. A similar argument was provided by Terenzio Mamiani, who, as an exile in Paris, attempted to convince the French government to intervene in the Papal States to avert the dangers connected with the local restoration backed by Austrian forces. ${ }^{21}$ The failure of this project paved the way for Mamiani's acknowledgment of the impossibility for Italy to pursue independence and unity with the support of any foreign power. His judgment essentially revolved around the recognition of the selfishness driving the individual 
states in the international arena. The European project, therefore, appeared fundamentally flawed to Mamiani, as it would hinder the free deployment of Italy's national character and further enforce its servility to the stronger powers of the continent.

While the verdicts on the vision of a unified Europe among nineteenth-century Italian political thinkers diverged - both in terms of their judgments on the encounter of nationalist and cosmopolitan sensitivities and with regard to the acknowledgment of the existing asymmetries between the peninsula and the rest of the continent - their debates on the unification of the country were often connected with reflections on the European dimension of politics. Put simply, for many political thinkers of the Risorgimento, reflections on the political organization of a unified Italy naturally entailed the need to interrogate where the country was to stand in relation to the other continental powers. The juxtaposition of national and European themes reflected a bi-directional relationship between Italy and Europe in the Risorgimento political imagination: not only did Italian intellectuals question the extent to which Italy was to take part in the vision of a European order, but they also - and more importantly - explored the extent to which foreign powers were to inform the process of Italian unification. This intuition is an opportunity for historians of the Risorgimento who understand this period as characterized by transnational connections to attempt to map out the European forces acting on the process of shaping the Italian national identity.

\section{National primacy and transnational sensitivities}

Nation is not exclusively a political concept. Alberto Banti reminded us that national discourse imposed itself, in the nineteenth century, as an amalgam of three distinct meanings: birthplace, the commonality of customs, and the historical cultural and linguistic community. ${ }^{22}$ The third meaning of the term 'nation' is the most interesting one since, especially during the eighteenth and nineteenth centuries, the articulation of an Italian national identity revolved around the historical development of the peninsula's culture and traditions. ${ }^{23}$ In consequence, the identification of cosmopolitan elements belonging to the discourse of unification ought to take into account much wider debates taking place throughout the decades preceding 1861, going beyond a purely political domain and highlighting the thematization of European modernity as part of a broader cultural and intellectual milieu. What ought to be investigated is the openness of Italian intellectuals towards foreign ideas, seen not only 
as a means to contribute to the definition of a national identity, but also as conducive to the negotiation of a space for Italy in the intellectual life of the continent.

The centrality of the topic of nation owes much to Vincenzo Cuoco's speculation at the beginning of the nineteenth century. Cuoco, who famously fled Naples following King Ferdinand IV's retaliation against the supporters of the Neapolitan Republic briefly established in 1799 by the French, devoted his work to a clear goal, one that already revealed the need for Italy to acquire a unified national cultural and philosophical character to stand tall in the contemporary philosophical landscape of Europe. Specifically, Cuoco aimed at 'forming the public spirit of the nation' and 'beginning to engage, at least with our thought, with other nations, growing accustomed to considering the glory of Italy as a shared one'. ${ }^{24}$ Crucially, while the concept of nation was generally adopted by the Southern émigré as a signifier for the Mezzogiorno alone, recent historiography has highlighted how his works featured the earliest theorization of the nazione del Risorgimento discussed by Banti. ${ }^{25}$ This was because at the core of Cuoco's verdicts lay a remarkable sensitivity to the asymmetries characterizing the relationship between an Italian spirit and its continental counterparts, notably France's: in his analysis, the French Revolution had brought about a sense of unity and solidarity that was simply missing in Italy, due to the failure of the 1799 revolutionary impulses, so deepening the gap between the country's 'two peoples', a well-off minority and a badly off majority, on whose reconciliation hinged the cultural and political unity of the nation. ${ }^{26}$

Elsewhere, he applauded the US Bill of Rights for appealing to the public sentiment of the American people, suggesting that even the political organization of a country largely depended on a solid national identity and shared values and customs. ${ }^{27}$ This operation could only be achieved by fostering 'self-esteem' in Italy's public spirit, a quality observable, in Cuoco's view, in French and English debates on their respective national character. ${ }^{28}$ An understanding of the means by which European nations managed to acquire greater 'self-esteem' led the Neapolitan author to identify the rediscovery and evaluation of a nation's cultural tradition as conducive to a stronger national unity: Germany and France, he argued, 'have endowed history with a dramatic garb which renders it at once more pleasant and more instructive. For the same reason that people prefer fables to speeches, they prefer drama to fables, for they become fellow citizens of the protagonists of the story, and they are instructed almost as if witnessing and 
acting in the first person, which is the easiest and most effective way to instruct oneself'. ${ }^{29}$

Cuoco's call for the articulation of an organic national identity clearly stemmed from his perception of the asymmetrical encounter between Italy - a nation yet to be culturally, let alone politically, unified and other European powers that championed shared values, sentiments, culture and customs. It did not, however, take long for Cuoco to elaborate a blueprint for the intellectual unification of the nation. This took the form of an epistolary novel, Plato in Italy, published between 1804 and 1806. Cuoco presented it as a translation of an imaginary ancient Greek manuscript, detailing Plato's visit to Southern Italy. In the book, the Greek philosopher visits a number of small communities that display strikingly progressive customs, such as the complete emancipation of women among the Sannites, excellent organizational skills, a very creative language, peaceful behaviour and sheer brilliance in the scientific and intellectual domains. These talents are associated with an obscure Pythagorean genius, which Plato comes to identify with the historical making of the Italian national character: 'I venture to say', he declares, 'that Pythagoras never existed; he is rather an idea conjured up by people to denote a system of cognitions whose origins are very ancient, and that has been conserved and handed down through a board of wise men who were born and raised in Italy'. Cuoco identifies these 'wise men' as the Etruscans, regarded as the bearers of the 'most ancient wisdom of the Italians' initially theorized by the Neapolitan philosopher Giambattista Vico. ${ }^{30}$ This notion leads Plato to acknowledge the Italians' superiority over the Greeks, as 'these nations that we deem barbaric have been cultured long before us'. ${ }^{31}$ Cuoco's Plato in Italy can be read as a metaphor for the encounter, in the nineteenth century, of the Italian and the French nations: the boastfulness and over-inflated sense of pride of the external observers is dramatically challenged by the observation of the 'Pythagorean genius' of the Italians. Therefore, just as Cuoco's Plato was forced to recognize Italy's cultural superiority over Greece, the French of the present must acknowledge the uniqueness of the peninsula's tradition and its historical intellectual primacy over Europe.

This notion of primacy is unquestionably a key concept to investigate in order to make sense of Italy's relationship with the European intellectual landscape of the nineteenth century. An investigation of this concept, however, is rendered problematic by the fact that it served a dual purpose: on the one hand, it allowed Italian thinkers to appeal to their tradition to challenge their perceived asymmetrical position in relation to contemporary experiences of European modernity; on the 
other, it erected a wall around the country's cultural heritage, rendering it untouchable and fundamentally hostile to foreign influences. At any rate, while the transnational implications of the notion of primacy remain an open question, the relevance of this concept to the discourse of the unification is not in doubt: by projecting this idea to the core of the debates concerned with the cultural unification of Italy, Cuoco contributed to the definition of the Italian people as a cohesive and organic unit, popularizing his belief in the unified nation as a reflection of a shared cultural heritage.

Following Vincenzo Cuoco's exhortation to embrace Italy's great tradition, there was a proliferation of works arguing the same: Ugo Foscolo's Sepolcri praised the resilience of the Italian national character, positing that it was exactly on the example of the men of genius of the past that a newfound cultural cohesion ought to be established; Giuseppe Micali's book L'Italia avanti il dominio de'romani (1810) went even further back, connecting the efforts of the present with the shared pre-Roman origins of the Italian people; Angelo Mazzoldi's Delle origini italiche e della diffusione dell'incivilimento italiano (1840) linked the historical origin of the Italian nation with Plato's allegory of Atlantis, the fictitious embodiment of the ideal city-state detailed in the Republic, to symbolize the historical intellectual primacy of Italy over other European nations. At any rate, while these works differed in so far as they tended to locate the origin of an Italian national culture in different areas and different historical periods, their most striking shared feature was a passionate cult of history and of the past. It is difficult, therefore, to see how the primacy of Italy - which, according to Foscolo, was still observable with Machiavelli and Galileo - could be rescued from a sterile cult of the past and fully projected into the context of the nineteenth century. New questions therefore emerged: could Italy's primacy still be observable in the present? How would it inform the country's relation to other European nations?

One of the most interesting and notorious answers to these questions appeared in 1843, when Vincenzo Gioberti's essay Del primato morale e civile degli italiani proposed an unconventional solution to the problem of the unification, indicating, at the same time, how the country was to stand in relation to its European peers. Initially associated with Mazzinian ideals, to such an extent that his self-imposed exile was caused by unjust accusations concerning his alleged involvement with initiatives promoted by the Giovane Italia in the early 1830s, Vincenzo Gioberti soon became one of the most influential moderate liberals of the 1840s, who, in direct opposition to Mazzini's call for political action 
'from below', sought to elaborate programmes of reform in concert with the existing powers and with the support of the liberal aristocracy, but without profoundly altering the status quo. Gioberti's Primato proposed a reprise of Guelph federalism, arguing in favour of the full liberation from foreign influences and the transformation of Italy into a confederation of existing states, with the Pope acting as a symbolic head of the union. ${ }^{32}$

Gioberti's political project, however, reflected much wider considerations on the historical character of the Italian nation that appeared to be consistent with the ongoing tendency to look at Italy's past traditions to remodel the present and shape the future: his was a precise understanding of Italian history, concentrating on the identification of religion as an inherently national institution. The Church was seen as the chief source of Italy's cultural unity and prosperity in the past, as well as a guide to follow if the country was to carve out a prominent position for itself in contemporary European politics. ${ }^{33}$ Gioberti's idea was not a novel one. It was the Neapolitan Giambattista Vico who, more than a hundred years earlier, had spoken of Christianity as the prime source of cultural unity, ${ }^{34}$ but these observations appeared in Gioberti with unprecedented force, further amplified by the political significance that they bore. The author's understanding of the history of Italy, the 'religious nation par excellence', ${ }^{35}$ was essentially an inquiry into its primacy and the ways in which this had become manifest throughout history: the spiritual powers supporting the edifice of Italian culture and politics made the latter tower above all other nations of Europe for centuries, granting Italy an authoritative status in all aspects of knowledge from philosophy to literature, from science to fine arts, from political theory to history, which virtually no one could challenge.

Ever since Roman times, Gioberti argued, the historical development of Italian culture had been inextricably linked with the actions of the Church: Rome's position at the core of Christian Europe was synonymous with a moral and civic vantage point over the rest of the continent. Even after the end of the Roman Empire, the Church managed to maintain a degree of unity and cohesion, at least in terms of shared tradition and customs, among the people of the peninsula. The centuries following the end of the Empire, he continued, witnessed the continuous efforts of the Church to rescue Italian culture from the threat of fragmentation, especially considering the tendency, particularly evident between the eighteenth and nineteenth centuries, to portray the papacy as an obstacle to national unification. ${ }^{36}$ The Reformation aggravated the threat of divisions, not only in terms of the immediate challenge it posed to the 
unity of Christianity, but also - and, in Gioberti's view, even more dramatically - because of the introduction of foreign 'barbarian', subjectivist and empiricist, ideas into the philosophical landscape of the peninsula. ${ }^{37}$ For these reasons, Italy found itself in a position of subordination to the emerging European powers such as France, England and Prussia. France, in particular, was targeted with remarkable force by Gioberti: the actions of Charles VIII, Louis XIV and, later on, Napoleon, were accused of having dramatically challenged Italy's aspirations to independence and having contributed to spreading a tendency to 'corrupt, maim and uproot' the principles of divine revelation, by encouraging a blind obedience to the ideas of René Descartes. ${ }^{38}$ As a result, Italian culture, tainted with a servile imitation of foreign ideas, ideologies and institutions, engaged with the rest of Europe in a relationship of dependence, strongly hindering, on the one hand, the country's unique spiritual status and, on the other, preventing the flourishing of the local, native culture.

Yet the acknowledgment of the asymmetrical nature characterizing Italy's relationship to the rest of Europe from the Reformation onwards did not prevent Gioberti from offering a positive evaluation of the country's historical primacy in the context of the Risorgimento. He boldly stated, in fact, that 'Italy features within itself, mainly thanks to religion, all the necessary conditions for its national and political Risorgimento', ${ }^{39}$ arguing against Mazzinian revolutionary ideals and the dependence on foreign intervention. All it takes, he posited, is the consolidation of national culture, along lines informed by the historical pre-eminence of the Church in the intellectual life of Italy, as well as the perpetuation of its centrality in politics, a programme seen as unquestionably consistent with the country's history. ${ }^{40}$ Yet while the book, both in its historical analysis and its propositions for the Risorgimento, revealed an interest in the cultural and political dynamics of the wider continent, the tone was not a cosmopolitan, but a nationalist one. More specifically, Gioberti's argument rested on the idea that the relationship between Italian and foreign culture must be radically altered, with preference given to native forces over external ones.

The idea of complete closure to foreign influences, already visible in Antonio Rosmini's essay Nuovo saggio sull'origine delle idee (1830), achieved wide popularity thanks to the dissemination of Gioberti's Primato, which was circulated in virtually all regions of Italy. Francesco De Sanctis recounted, in his autobiography La giovinezza, how, on reading the book, he had immediately identified it as the ideological forerunner of a new, rapidly growing school of thought that championed the absolute primacy of the Italian language, rhetoric, style and culture at large, rejecting 
any engagement with its European counterparts. ${ }^{41}$ This view was reflected by the popularity, in the 1840s, of literary purism, a trend upholding the imitation of Italian language and literature of the fourteenth, fifteenth and sixteenth centuries, in direct opposition to the French inflections perceivable in various regions. Indeed, Gioberti's Primato was exceptionally critical of France, which he accused of having 'infected', with its ideas and language, the cultural patrimony of other nations. Germany was commonly targeted, too: Luigi Palmieri, who became a university professor of philosophy and logic in Naples in 1847, believed in the need to prevent the spread of the dangerous 'German pantheism' in national culture, encouraging, instead, the systematic rediscovery of the local tradition: 'In declaring myself openly to be a loyal follower of our native thought', he claimed in the introductory lecture of his university course, 'I cannot but reprove the repeated attempts to enable certain foreign doctrines to take root among us. Today we are infested with German encroachments because there are some teachers who would indoctrinate our youth with German pantheism, especially with that brand which is rigged out in the imposing and grandiose cloak of George Frederich Hegel. ${ }^{42}$

Gioberti and Palmieri's examples of exasperated cultural nationalism could hardly represent an encouraging background for compelling developments in Italian philosophy, let alone for the movement of Italy towards a European conception of modernity and the negotiation of a vantage point in the intellectual landscape of the continent. While their arguments attempted to strengthen a national identity via cultural unity, they remained ambiguous as to the relevance of Italy's past primacy in the present, and hence failed to articulate the progressive character of the country's intellectual forces. Not long before unification, therefore, the asymmetry between Italy and Europe had not been overcome: on a purely socio-economic level, the peninsula paled in comparison to the other powers of the continent; on a political level, the cosmopolitan enthusiasms of the Mazzinian generation, especially following the battle of Goito on 30 May 1848, had been replaced by a widespread feeling that the cause of national unification could not be pursued by relying on anyone other than Carlo Alberto, thereby further establishing the centrality of Piedmont in Risorgimento politics. It was in the intellectual field, however, that nineteenth-century Italy presented the most vehement resistance to European ideas: fully conscious of the contemporary decline of Italian philosophy, several intellectuals of the period opted for a passionate, yet fruitless, veneration of the country's past tradition, based on debatable notions of historical primacy, therefore shielding the peninsula from any foreign contamination. 


\section{Challenging Asymmetry: Spaventa's 'circularity' of European thought}

This nationalist swing in cultural debates of the nineteenth century was particularly marked in the South, where, especially after the revolutionary turmoil in 1820-1, institutional arrangements set forth by the Bourbon monarchy had strongly undermined the penetration of European ideas into the Kingdom. ${ }^{43}$ Already in 1820, King Ferdinand returned to Latin as the language of education, substantially increased import taxes on foreign books, and issued a list of prohibited texts. Libraries in the Kingdom were subject to regular inspections carried out by a special commission and, in most cases, witnessed significant portions of their collections, most notably German philosophy books or treatises on the Enlightenment, being taken away. At the end of June 1821, the King symbolically marked the rejection of late eighteenth-century French philosophy by publicly burning books by Voltaire, Diderot and d'Alembert. After the Revolution of 1848, the Bourbon monarchy renewed its efforts to maintain control over the Kingdom via the creation of a loyal and efficient bureaucracy, the reorganization of the army and the refusal to engage with European politics and ideas, encouraging instead an unconditioned allegiance to Neapolitan culture and tradition, as was often lamented by local chroniclers. ${ }^{44}$

At the same time, the South also represented the cradle of a truly progressive philosophy, namely one that fully blurred the lines between nationalism and cosmopolitanism, one that completely subverted notions of primacy and asymmetries, and finally depicted Italy as a philosophical centre of European modernity. While, in fact, the neo-Guelph Giobertian solution was acquiring traction in public debates and intellectual circles, a group of Southern intellectuals, brought together by passionate support for the cause of unification, a common revolutionary fervour and a particular fondness for German idealism, emerged as the forerunner of an intellectual revolution aimed at establishing the cultural unity that was seen as the most salient characteristic of modern European nations, especially Germany. Among these intellectuals, Bertrando Spaventa quickly affirmed himself as the figurehead of the new worldview. Born in the Abruzzo town of Bomba in 1817, Bertrando moved to Naples at an early age and, together with his brother Silvio, wrote for the periodical Il Nazionale, a left-leaning newspaper that served as a voice for the radical Neapolitan youth. After the failure of 1848, Spaventa, unlike his brother who was sentenced to prison, was exiled to Turin, where his journalistic activity remained devoted to the popularization of Hegel's philosophy as 
a paradigm for the cultural unification of Italy, a means for the promotion of secular politics and, broadly speaking, a guiding light for the future of Europe. ${ }^{45}$ It was between 1858 and 1860, however, with his lectures at the universities of Modena and Bologna, that Bertrando's philosophical vision was fully realized as the theory of circularity of European thought, later published in the volume La filosofia italiana nelle sue relazioni colla filosofia europea.

A dart of criticism directed against Gioberti's neo-Guelph cultural nationalism, Spaventa's best-known work dismantled the popular view that Italian philosophy was fundamentally detached from modern European thought. ${ }^{46}$ In this sense, the blind exaltation of the country's past tradition was condemned as a deplorable solution and a means of shielding oneself from the ideas of present-day Europe. Italian philosophy, according to Spaventa, did not end with the Renaissance; rather, it 'went on to develop in freer lands and among freer intellects'. ${ }^{47}$ Consequently, engagement with contemporary European ideas was seen as synonymous with the discovery of a new chapter in the life of Italian philosophy, namely one that took place abroad: 'seeking Italian philosophical thought in its new fatherland does not entail a servile imitation of German nationality. Rather, it constitutes a recovery of something that belonged to us, of something that, under different guises, has become part of a universal spirit, the essential condition of our civilization, as well as all other people's. It is not our philosophers of the last two centuries, but Spinoza, Kant, Fichte, Schelling and Hegel who are the true disciples of Bruno, of Vanini, of Campanella, of Vico and other illustrious authors. ${ }^{48}$

Spaventa proposed a very elastic definition of philosophy that was not bound to specific national traditions, but emerged as a global phenomenon, stemming from intergenerational, transnational exchanges. Already during Roman times, it was possible to speak of the transnational nature of philosophy's vocabulary: drawing extensively upon Vico's definition of Antiquissima Italorum Sapientia, Spaventa suggested that many terms were characterized by a philosophical meaning that was too great to have evolved out of the popular use of the terms themselves. Consequently, he concluded, they must have been borrowed from foreign populations, particularly the Etruscans and Ionians, as already hinted by Cuoco roughly half a century earlier, in his commentaries on Vico. Transnational intellectual exchanges were even more evident from the Renaissance onwards and their effect was said to be extremely visible in the present: 'Modern philosophy', Spaventa claimed, 'is not the work of a single nation, but of all'. Those that appeared to be 'national 
philosophies' were, instead, 'nothing more than stations through which thought, in its immortal course, passes. Modern philosophy, therefore, is neither exclusively English, nor French, nor Italian, nor German, but European. ${ }^{49}$

Spaventa identified Italy during the Renaissance as the birthplace of modern ideas, paying particular attention to the ongoing rejection of Scholastic philosophy via the rehabilitation of inquiries on nature and subjectivity. He then illustrated how these innovations ought to be seen as conducive to the encounter of local and foreign philosophies: Giordano Bruno's definition of Nature as Deus in rebus was said to have anticipated Spinoza's Deus sive Natura, the manifesto of modern immanentism; Tommaso Campanella's emphasis on sensitivity and experience as the basis of all knowledge was described as the forerunner of empiricism and Cartesian rationalism. As the mature reflections of Spinoza and Descartes revealed the magnitude of the dichotomy between sense perception and intellect, man was still perceived exclusively as an effect, that is, as a product of God's creation. It was exactly the critique of this mono-directional account of causality, operated via Locke's empiricism in England and Gottfried Leibniz's Monadology in Germany, that sought to elaborate an account of man as cause, namely as the free maker of himself. While these ideas originally appeared abroad, it was only in Italy, Spaventa continued, that the tension between man as effect and man as cause was resolved. The philosopher credited for this innovation was Giambattista Vico, who blurred the definitions of the two categories by amalgamating them in a wider notion of progress, seen as the World Spirit's perpetual process of self-negotiation. 'Vico denies any parallel', Spaventa writes; 'nature is the phenomenon and the basis of Spirit, the premise that Spirit makes for itself, in order to be true unity. True unity, the true One, true development: development of itself; from itself, via itself, to itself: that is, completely itself. ${ }^{50}$

Vico's innovation paved the way for the elaboration of a new metaphysics, accounting for perpetual progress and self-negotiation, rather than immediate causation. In a particularly poignant section of his book, Spaventa claimed that 'Vico anticipates the problem of knowledge, demanding a new metaphysics anchored to human ideas; he is sensitive to the idea of Spirit, hence creating philosophy of history. Vico is the true precursor of Germany. ${ }^{51}$ This is exactly where, according to the author, the diaspora of Italian philosophy was most dramatically observable: after Vico, it was only in other European countries, particularly in Germany, that a meaningful intellectual life had been taking place. Immanuel Kant was to be credited for the elevation of the themes problematized 
by Vico into a transcendental psychologism, resolving the problem of knowledge and its intelligibility with the intuition of its synthetic unity. ${ }^{52}$ Later on, Spaventa continued, the presence of the same problem could be observed in Fichte's Selbstbewußtsein, the transcendental realism of Schelling's Naturphilosophie and, more importantly, Hegel's idealism, positing the ultimate question as to how Spirit realizes itself in history and in man's experience of it. According to Spaventa, it was exactly in the Italian philosophy of the Renaissance that the debates animating the nineteenth-century European intellectual landscape would deepen their roots: La filosofia italiana illustrated a well-defined trajectory linking Bruno and Campanella with present-day German thought, brought together by the persistent search for unity in history.

The stage was now set for the final thrust of Spaventa's argument. To restore its status of pre-eminence among the nations of Europe, Italy had to rediscover its own philosophy in its mature, cosmopolitan form: as the country's tradition had 'developed in the motion of German intellects', it was necessary, for the thinkers of the peninsula, not to engage with foreign authors 'in the same way as goods are imported', but via the recognition of their shared intellectual genealogy. ${ }^{53}$ This process, according to the author, was already well underway. Both the Italian and the German traditions were said to have deep roots in debates initially appearing during the Italian Renaissance and, consequently, they were both concerned with the same questions. As proof of this, Spaventa drew a parallel between Pasquale Galluppi and Immanuel Kant: both had 'inherited' a concern for the problem of knowledge from Vico. As a result, thanks to his empiricist philosophical inclination, Galluppi was said to be 'unknowingly Kantian'. ${ }^{54}$ Similarly, Antonio Rosmini, notoriously critical of foreign ideas, was nonetheless said to have theorized a notion of 'primitive synthesis of reason and perception' mirroring Kant's notion of 'transcendental imagination', mediating between sense and intellect. ${ }^{55}$ Another interesting comparison was between Hegel and Gioberti: just as the German idealist had moved beyond his predecessors by positing the absolute self-awareness of Reason as a token of the infinite possibility of knowledge, Gioberti had overcome the limits of Galluppi and Rosmini by theorizing an 'Absolute Mind', decreeing the infinite potentiality of knowledge via the dialectic of its creative force. To paraphrase Spaventa's verdict on Galluppi, Gioberti was seen as 'unknowingly Hegelian', much closer to German idealism than he was ready to admit himself. It was only thanks to the recognition of the similarities between the Italian and German philosophical landscapes, Spaventa argued, that the peninsula could achieve the cultural unity observable in other European countries, 
thus creating 'a historical Italy, having its worthy place in the common life of modern nations'. ${ }^{56}$

\section{Conclusion}

The 'circularity of European thought' was not only an attempt to challenge notions of primacy, seeing the centrality of the Italian tradition as limited to the Renaissance, but also - and much more importantly - a means of de-provincializing nineteenth-century debates taking place in the country, showing how they reflected a much more modern, European experience of modernity. This verdict rests on a series of interconnected insights.

First, the political and cultural discourse concerned with the unification of Italy reflected a concern for the nation's role in the broader picture of the whole continent. Ever since the early decades of the Risorgimento, Italian intellectuals had questioned the extent to which a unified country was to partake in a European scheme of coexistence and cooperation. The variety of their answers was extraordinary, ranging from visions of a fully fledged continental federation to downright rejections of any foreign influence. Yet even the most markedly nationalist positions, such as Rosmini and Gioberti's, stemmed from cosmopolitan premises or, at least, from the recognition of the historical tendency of nations to come into contact and affect one another.

Secondly, while the analysis of nineteenth-century thinkers' appraisal of Italy's place in Europe already revealed the strikingly cosmopolitan morphology of the national discourse, debates on Europe's relationship to Italy, especially in the broader cultural and philosophical spheres, provided even more interesting food for thought, challenging notions of asymmetries and imbalances between the two. Bertrando Spaventa's theory of the circularity of European thought was the most progressive and convincing attempt to rethink the relation between the country and the continent, dealing a hard blow to the widespread ultra-nationalist views of the 1840s. More specifically, Spaventa beat Gioberti at his own game: his argument rested on the same premise as his opponent's, namely the recognition of the centrality of Italian Renaissance philosophy. Unlike Gioberti, however, who saw it as fundamental to a nationalist discourse, Spaventa slotted it into the wider cosmopolitan ideal of a purely European intellectual history, positing a serious challenge to the idea of an asymmetrical encounter between Italy and the rest of the continent. In this sense, the theory of the circularity 
of European thought towered above the plurality of nineteenth-century theories about this encounter, thanks to its originality and the breadth of its scope.

A third insight had to do with the very nature of the challenge posited: once again, unlike Gioberti, who countered the perceived asymmetry by completely turning it on its head, Spaventa posited that no imbalance had ever existed, considering that the history of European philosophy was one of constant, self-perpetuating transnational exchange, of continuous dialogue among its parts, and of non-competitive encounter.

Lastly, it is notable that the most compelling and successful attempt to negotiate a vantage point for Italy in the intellectual life of modern European nations came from the leading exponent of a group of Southern thinkers. And noticing that the South, a peripheral region in a peripheral nation of Europe, put itself and the rest of Italy at the very centre of the continent's intellectual landscape is a charming discovery.

\section{Notes}

1. Paradiso, XXVII, 84.

2. De Monarchia, III, 17.

3. Federico Chabod, Storia dell'idea d'Europa. Bari: Laterza, 2005, 44-80.

4. Benedetto Croce, Storia d'Europa nel secolo decimonono. Bari: Laterza, 1932.

5. Antonio Gramsci, Quaderni dal carcere. Turin: Einaudi, 1963

6. Excellent illustrations of the transnational nature of Risorgimento political thought can be found in Christopher Bayly and Eugenio Biagini (eds), Giuseppe Mazzini and the Globalisation of Democratic Nationalism 1830-1920. Oxford: Oxford University Press, 2008; Maurizio Isabella, Risorgimento in Exile: Italian Émigrés and the Liberal International in the Post-Napoleonic Era. Oxford: Oxford University Press, 2009; Maurizio Isabella, 'Nationality before Liberty? Risorgimento Political Thought in Transnational Context', Journal of Modern Italian Studies, 17.5 (2012): 507-15; Martin Thom, Republic, Nations and Tribes. London: Verso, 1995.

7. Richard Johnson, 'Educational Policy and Social Control in Early Victorian England', Past \& Present, 49 (1970), 96-119.

8. Louis Maggiolo, Ministère de l'Instruction Publique: statistique rétrospective. Etat récapitulatif et comparatif indiquant par département, le nombre des conjoints qui ont signé l'acte de leur mariage aux XVII ${ }^{\mathrm{e}}$., XVIII ${ }^{\mathrm{e}}$. et XIX ${ }^{\mathrm{e}}$. siècles. Documents fournis par 15923 instituteurs, recueillis et classés par M. Maggiolo, recteur honoraire, chargé d’une mission spéciale per M. le Ministre de l'Instruction Publique. Paris, 1879.

9. Dieter Langewiesche and Klaus Schonhoven, 'Arbeiterbibliotheken und Arbeitlektüre in Wilhelminischen Deutschland', Archiv für Sozialgeschichte, 16 (1976), 135-204, statistic from 140.

10. Guido Pescosolido, Unità nazionale e sviluppo economico, 1750-1913. Bari: Laterza, 1998.

11. Denis Mack Smith, Storia d'Italia dal 1861 al 1997. Bari: Laterza, 1997, 60.

12. Vera Zamagni, 'Ferrovie e integrazione del mercato nazionale nell'Italia post-unitaria', Studi in onore di Gino Barbieri: problemi e metodi di storia ed economia. Salerno: Ipem Edizioni, 1983, 1638-41.

13. Giovanni Federico, 'I fattori della distribuzione', Storia dell'economia italiana, III: L'età contemporanea: un paese nuovo. Turin: Einaudi, 1991, 188.

14. Gian Domenico Romagnosi, La scienza delle costituzioni. Turin: Canfari, 1849, 384. 
15. Romagnosi, Scienza, 400-1.

16. Carlo Cattaneo, Opere edite ed inedite, vol. V. Firenze: Le Monnier, 1881-92, 103. An excellent commentary on Cattaneo's political thought is available in Filippo Sabetti, Civilization and Self-Government: The Political Thought of Carlo Cattaneo. Lanham, MD: Lexington, 2010.

17. Felice Momigliano, Carlo Cattaneo e gli stati uniti d'Europa. Milano: Treves, 1919, 54.

18. See Carlo Cattaneo, Dell'insurrezione di Milano nel 1848 e della successiva guerra. Lugano: Tipografia della Svizzera Italiana, 30; and Paolo Bagnoli, L'idea dell'Italia, 1816-1861. Reggio Emilia: Diabasis, 2007, 142.

19. Giuseppe Ferrari, La Chine et l'Europe: leur histoires et leur traditions comparées. Paris: Didier, $1867,597-8$.

20. Cesare Balbo, Delle speranze d'Italia. Capolago: Tipografia Elvetica, 1844, 209-42.

21. Terenzio Mamiani, 'Lettera autobiografica a Giuseppe Zirardini', Lettere dall'esilio. Roma: Dante Alighieri, 1839, 50-1.

22. Alberto Maria Banti, La nazione del Risorgimento. Turin: Einaudi, 2000, 4-5.

23. See also Franco Venturi, L'Italia fuori d'Italia. Turin: Einaudi, 1973.

24. Vincenzo Cuoco, 'Programma del Giornale Italiano', Scritti vari. Bari: Laterza, 1924, 3.

25. Antonino De Francesco, The Antiquity of the Italian Nation. Oxford: Oxford University Press, 2013, 46.

26. Vincenzo Cuoco, Saggio storico sulla rivoluzione napoletana del 1799. Bari: Laterza, 1976, 90.

27. Cuoco, Saggio, 39-40.

28. Cuoco, 'Programma', 3-4.

29. Vincenzo Cuoco, Pagine giornalistiche. Bari: Laterza, 2011, 652.

30. Vincenzo Cuoco, Platone in Italia. Bari: Laterza, 2006, 101.

31. Cuoco, Platone, 103.

32. Vincenzo Gioberti, Del primato morale e civile degli italiani. Capolago: Tipografia Elvetica, 1846, 285.

33. Gioberti, Del Primato, 311-15.

34. Giambattista Vico, Principi di scienza nuova, vol. II. Milan: Gaspare Truffi, 1831, 200.

35. Gioberti, Del primato, 31.

36. Gioberti, Del primato, 88.

37. Gioberti, Del primato, 186-8.

38. Gioberti, Del primato, 251.

39. Gioberti, Del primato, 116.

40. Gioberti, Del primato, 117-21, 273-5.

41. Francesco De Sanctis, La giovinezza: frammento autobiografico. Naples: Morano, 1969, 338.

42. Luigi Palmieri, Prolusione alle lezioni di logica e metafisica nella cattedra della R. Università degli studi. Naples: Nobile, 1848, 28.

43. See in this context the previous chapter by Jens Späth.

44. De Sanctis, La giovinezza, Bari: Laterza, 31, 319; Francesco Del Giudice, 'Le piaghe dell'istruzione pubblica napoletana', Atti del Regio Istituto d'Incoraggiamento, X, Naples, 1860, 1-9; Vincenzo Flauti, L'unguento e le pezze fatte alla nostra istruzione pubblica da un cattivo barbiere, che vuol farla da demiurgo. Naples, 1860, 3-4; Bertrando Spaventa, 'Lettera al fratello Silvio, 27.11.1861', in La filosofia italiana nelle sue relazioni colla filosofia europea. Bari: Laterza, 1902, 285-8.

45. Fernanda Gallo,'Philosophical Revolution and the Shaping of European Consciousness: Bertrando Spaventa's "La filosofia italiana nelle sue relazioni colla filosofia europea", Phenomenology and Mind, 8 (2015), 212-22; see especially 215.

46. Bertrando Spaventa, La filosofia italiana nelle sue relazioni colla filosofia europea. Bari: Laterza, 1902, 49.

47. Bertrando Spaventa, Principii di filosofia. Naples: Ghio, 1867, 21.

48. Spaventa, Principii di filosofia, 21.

49. Spaventa, La filosofia italiana, 21.

50. Spaventa, La filosofia italiana, 124.

51. Spaventa, La filosofia italiana, 31.

52. Spaventa, La filosofia italiana, 141.

53. Spaventa, La filosofia italiana, 200-2, 8 .

54. Spaventa, La filosofia italiana, 8.

55. Spaventa, La filosofia italiana, 162.

56. Spaventa, La filosofia italiana, 202-3. 
10

\section{'The Greatest City the World has Ever Seen': London's Imperial and European Contexts in British Public Debates, 1870-1900}

Tessa Hauswedell

\section{Introduction}

The important political, economic and symbolic role of large European cities, especially during the nineteenth and twentieth centuries, has been widely acknowledged and studied. Cities feature prominently in Jürgen Osterhammel's magisterial survey of the nineteenth century, The Transformation of the World, which devotes a substantial section to cities and their development during the nineteenth century. ${ }^{1}$ For the twentieth century, surveys such as Global Interdependencies: The World after 1945, edited by Akira Iriye, include sections on the development of global cities in the second half of the twentieth century. ${ }^{2}$ It is generally acknowledged that while Europe evidently underwent urbanization processes from the seventeenth century onwards, the unprecedented growth of cities in the nineteenth century on a truly cataclysmic scale heightened their role as an agent of social, political and economic change. Peter Clark points out that 'during the 1900s the major cities of Western Europe became exciting laboratories and models for the rest of urban Europe and beyond'. ${ }^{3}$ It is beyond the scope of this chapter to survey the extensive literature which exists on this topic, but it is worth pointing out that historians have sought to understand the complex ways in which cities were implicated in processes of nation- and empire-building in particular, or focused on the city as an organizing principle, in order to understand processes of urbanization and globalization more broadly. Notable historians such 
as Pierre Yves Saunier emphasize the merit of moving from primarily descriptive urban studies towards more interactional studies, and to consider cites as types of formation which have operated as 'stations of transport, trade emporiums, commanding places of the economy, gateways and destinations for migrants, cultural capitals or centre of revolutionary activities'. ${ }^{4}$

Saunier and others point to the latter half of the nineteenth century as the time when European cities became connected in a more systematic fashion, when enduring structures and legal and organizational frameworks began to take shape, and exchanges of knowledge tied these cities closer together. ${ }^{5}$ Yet Osterhammel strikes a more cautious note and maintains that in the absence of empirical studies that actually chart the 'manner and frequency of contact amongst the largest world cities' during the nineteenth century, it might be more accurate to look towards the twentieth century as the time in which cities became interconnected as a truly 'permanent fabric of interaction and communication'. ${ }^{6}$ Still, most would contend that even if this interconnection was not always explicitly acknowledged or foregrounded, European cities of the nineteenth century were in contact with each other through trade, diplomatic relations, and cultural and intellectual exchanges. These contacts were motivated as much by a desire for knowledge and exchange in order to improve living conditions in the cities, as by a sense of rivalry and competition for prestige and influence, which functioned much like a mirror of the nation-state rivalries of the time.

This notion is also put forward by the urban/historical geographers David Gilbert and Felix Driver, who have written extensively on London and its function as an imperial metropolis within the British Empire. In line with other scholars they have pointed to the connection between the idea of empire and the imperial city and have contended that if the imperial city was at the centre of the world, the empire was now at the heart of urban experience'. ${ }^{7}$ Moreover, they suggest, the late nineteenth-century discourse on London as an 'imperial city' did not exist in isolation. Rather, they note that 'in what was evidently a pan-European discourse on the imperial city between the mid-nineteenth century and the mid-twentieth, national models were defined in relation to other national models, in a spirit of competition as much as emulation'. ${ }^{8}$ They thus posit that debates about London as an imperial city did not take place solely in relation to national debates over imperial urbanism, but implicated a European dimension as well. Indeed, they stress that it is 'important to acknowledge the distinctively European dimension to the modern imperial city'. ${ }^{9}$ The growth of these global, imperial cites also 
affected questions of centre and peripheries. If Britain was the world's greatest empire, its capital London was at the very core of this enterprise. But how did other European cities fare in this respect - did they constitute imperial centres in their own right?

This present study aims to shed light on how London as a metropolis was referenced in comparison to other European cities in British newspapers of the late nineteenth century. The focus here is on the term 'metropolis', and how it underwent wide semantic shifts over the centuries in public debates. The aim, therefore, is not to provide an empirical study about the precise level or intensity of contact between European cities in the late nineteenth century. Rather, it lies in establishing relevant contexts and associations which the metropolis assumed in public debates in a national context. What was the defining tenor in public debates about the metropolis in British newspapers of the time? Further, drawing on Gilbert and Driver's claims, can we find indicators for an alleged pan-European context in regard to debates about the imperial metropolis in these newspapers?

The collections used here in order to identify some initial longitudinal trends in the use of the term 'metropolis' in relation to London and to other European cities include the nineteenth-century British Newspaper Archive (BNA) and also the Seventeenth and Eighteenth Century Burney Collection of British Newspapers (Burney Collection) and the Early English Books Online corpus (EEBO). ${ }^{10}$ This is accompanied by a more detailed analysis of one newspaper from the BNA, the London based Pall Mall Gazette (PMGZ), through a method called collocation analysis, undertaken by the digital tool AntConc. ${ }^{11}$ AntConc was originally developed by and for corpus linguists, and offers valuable functionalities for historians and humanities scholars who work with large-scale textual corpora. Collocation analysis provides context on recurring expressions and wordfields that appear in close proximity to a given concept such as 'metropolis', and facilitates a closer understanding of how the term was used and how its meaning changed over time.

\section{London as the prime metropolis}

The contours of London's dominance as a major metropolis in the nineteenth century are well established: it not only grew into the largest city in the world but was also widely considered as the only 'globally hegemonic' city of its time. ${ }^{12}$ It served as the undisputed centre of worldwide commercial and financial activity from around 1830 onwards, until it was superseded by 
New York at the beginning of the twentieth century. Britain was at the forefront of the industrial revolution, and the effects of rapid urbanization and industrialization occurred here earlier, and to greater effect, than in other European countries. Its growing overseas empire far surpassed that of all other European countries. For these reasons, London became increasingly known as 'the empire's capital' or the 'imperial metropolis of the world' from the early nineteenth century onwards in public usage, even if this did not always indicate admiration. ${ }^{13}$ For example, in 1830 the prominent pamphleteer and journalist William Cobbett commented on the use of the term in his pamphlet Rural Rides, in which he espoused his critical views of the developments affecting the city of London. In regard to the future of the city he wrote: 'But, what is to be the fate of the great wen of all? The monster, called, by the silly coxcombs of the press, "the metropolis of the empire"?"14 Despite Cobbett's dismay at the press, the term became more widely used by journalists and writers. An article from the London Standard newspaper in 1882 not only describes London as the 'greatest city the world has ever seen' but in the same sentence also points to its role as 'imperial metropolis'. ${ }^{15}$ In the heyday of Britain's imperial age, these forms of boosterism served to cultivate an image of the capital as the representative centrepiece of the British Empire, from which its various provinces, dependencies and peripheries were ruled and administered. They helped not only to highlight London's reach in political terms but also to underscore its role as the unchallenged seat of imperial rule and 'principal site of imperial trade and finance'. ${ }^{16}$ London was important as a showcase of an imperial city, since such cities, as Derek Keene points out, were important 'as symbolic capital and as sites where the material and ideological expression of that capital can be accumulated, displayed or obtained'. ${ }^{17}$

Other examples of boosterism include literary texts, travel accounts and tour guides about London, such as one published in 1902, grandly entitled The Heart of the Empire: Discussions of Problems of Modern City Life in England with an Essay on Imperialism. ${ }^{18}$ The theme was still present after the First World War, in a volume called London of the Future published in 1921 by the 'London Society', a civic group consisting mainly of architects who sought to discuss urban issues and foster the physical renewal of the city. The various contributions to the volume provide ideas and visions for London's public spaces, monuments and buildings. One chapter suggests that 'London should be officially recognized by the Empire as its capital, so that the whole Empire may take a pride in its beautification and development as the centre of the greatest political organization the world has ever known'. ${ }^{19}$ London is integrated neatly and unambiguously into the larger context of empire-building, and the desired trajectory for its future is expressed unambiguously: it is meant 
to stand as the representative centrepiece, the 'symbolic capital' of imperial pursuits.

In his extensive study of London as an imperial metropolis, Jonathan Schneer notes that the impact of empire 'imparted a certain atmosphere to the city's built environment; a certain ambiance to its culture; a certain tone to its politics'. ${ }^{20}$ That tone, it bears pointing out, was not always as confident and self-assured as in the examples above, for London was 'often regarded as an inadequate capital city for the British Empire'. ${ }^{21}$ The rivalry between London and Paris is well documented. Schneer states that 'for the greater part of the nineteenth and early twentieth centuries, and despite its self-acclaimed and widely acknowledged role as an imperial metropolis and world city, London suffered from ... a severe inferiority complex - in comparison to other European capitals, especially Paris. ${ }^{22}$ Doubts about its status were tied to the perceived lack of a befitting material expression of its imperial status but also - at least in the minds of socialist reformers such as Sydney Webb - to the inadequate living conditions in which the majority of the population lived. In his influential tract The London Programme Webb noted:

The largest city in the world, the capital of the Empire, cannot, in these democratic days, safely be abandoned to the insidious influence of its festering centres of social ulceration. We dare not neglect the sullen discontent now spreading among its toiling millions ... . Metropolitan reform has become a national, if not an imperial question. ${ }^{23}$

The pressing problems of urban discontent and poverty were taken up by numerous public figures, among them William Stead, the editor of the London-based Pall Mall Gazette which appeared from 1865 until 1922. The newspaper was initially regarded as one of the so-called' clubland' newspapers because its target reader was a 'gentleman relaxing in his club (probably in Pall Mall or St James' Street) between work and the night's social events'. ${ }^{24}$ Yet in 1883 , the PMGZ changed its outlook when William Stead assumed the editorship. He aligned the paper with a more liberal and progressive agenda, and opened it up to the lower middle classes by pursuing a more sensationalist newspaper style. Importantly, he also took a personal interest in what he regarded as the corrosive moral influence of modern city life on its citizens. ${ }^{25}$ Stead travelled to the United States in the 1880s and wrote books about his impression of American cities, especially Chicago. He edited and produced pamphlets in which he exposed the living conditions of London's poor. In 1885, the PMGZ published the 'Maiden Tribute of Modern Babylon' campaign, a series of 
articles on the problem of prostitution in London. The campaign was in support of a stalled piece of legislation aimed at eradicating under-age prostitution, which subsequently passed Parliament. While the 'Maiden Tribute' campaign is not going to be analysed in detail here, the image of London as a 'modern Babylon' offers one example of how the view of the metropolis was actively channelled by the press.

While London was clearly at the centre of this newspaper's concern, which other major European and indeed American cities did the PMGZ refer to and report on? Figure 10.1, below, provides a percentage-based overview of how often European and American cities are mentioned in the newspaper over a thirty-year period. Certainly, the growing American cities that William Stead was interested in are present, but the overall focus in the PMGZ during the late nineteenth century remained on established European cities. Unsurprisingly, Paris leads consistently by a wide margin, followed by Berlin, Rome, Vienna and Amsterdam, while New York is prominent ahead of Chicago and Washington.

Paris initially accounts for more than 60 per cent of the total references overall. By 1900, its prominence has lessened somewhat but it still accounts for half of the references. The position of Berlin, Rome and Vienna remains largely consistent over the thirty-year period, but lags behind New York, clearly the most prominent American city, before Washington, Chicago and San Francisco. Thus Paris emerges as the focal

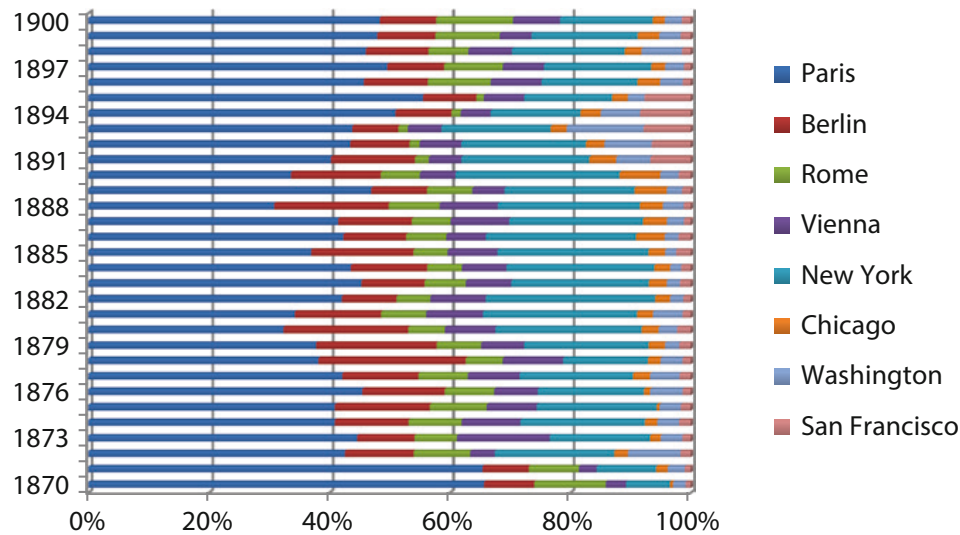

Figure 10.1 Percentage-based occurrences of European and American cities, excluding London, in the PMGZ during the period 1870-1900. Calculated by the author on the full-text archive of $P M G Z$ with frequencies derived from the AntConc tool. 


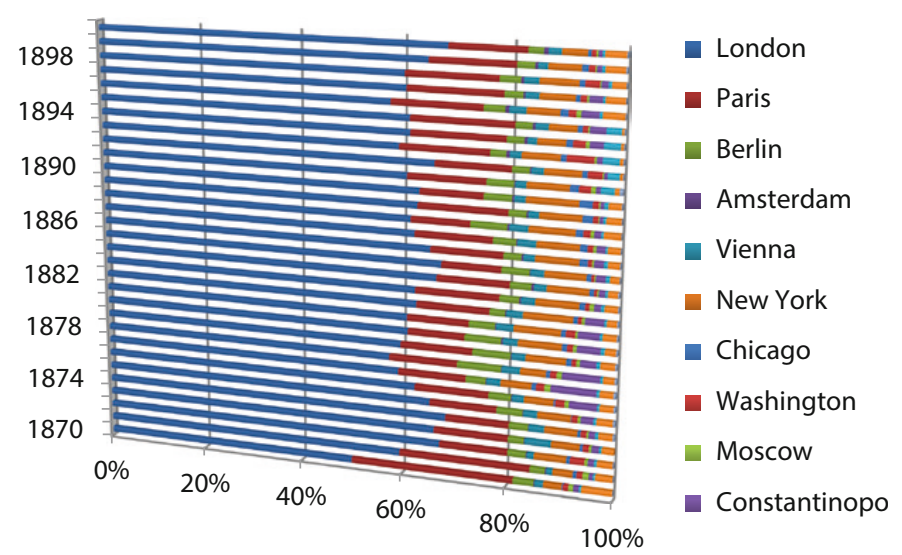

Figure 10.2 Percentage-based occurrences of selected European and American cities, including London, in the PMGZ during the period 1870-1900.

point for reporting from the Continent, while New York is the most prominent American city of its age within the PMGZ. If London is included in the count by percentages, Figure 10.2 indicates that on average around half of the references are to London and the other half to the aforementioned cities. But to what extent are these cities described as metropoles, and how is the term used?

\section{Changing meanings of the metropolis}

In its modern, secular meaning, a metropolis can be understood as a city that 'gives widely recognized expression to a certain culture', that emits cultural, political and social impulses beyond its borders which can function as a reference culture or an aspirational model for other cities. ${ }^{26}$ Originally, however, the Greek word 'metropolis' derives from metera mother. Thus the metropolis designates a 'mother city', one that was meant to sponsor and support other cities in its imperial reach. The word metropolis thus already contains the relational element of the central metropole and the colonies. Accordingly, the term has traditionally been used in the context of a centre and periphery, implying unequal, hierarchical constellations between the two entities. ${ }^{27}$ Yet, during the Middle Ages the term metropolis referred primarily to places of ecclesiastical power, and designated the extent of a bishop's reach. The ecclesiastical designation has not disappeared altogether, but this religiously inflected 
meaning of the metropolis began to weaken from about the eighteenth century, Richard Rodger claims. ${ }^{28}$ References to the term in newspapers increased from about 1750 as indicated in Figure 10.3 below, roughly when British overseas expansion began to take off.

The Early English Books Online corpus provides a useful additional resource - collocation analysis - in order to gain a sense of the contexts in which the term 'metropolis' was used from the eighteenth century onwards. Throughout the seventeenth century the strongest collocations for the metropolis are to the 'city' and to the unit of the 'province'. The fact that a metropolis was discursively most closely connected to a 'province' suggests that this provided the most important unit of administration at the time. Prominent also are collocations with places such as 'Ephesus' and 'Jerusalem', suggesting that the religious connotations of the term were still present, as well as a collocation with 'mother', suggesting that the image of the metropolis as a 'mother city' is present.

In the eighteenth century, however, references to cities such as Jerusalem and Ephesus have disappeared, as has the collocate 'province'. Instead, discursive connections are made to 'Kingdom', 'county', and the 'country', but also to the 'Empire', ahead of 'England', and also specifically to the city of 'London'. ${ }^{29}$

As the following analysis demonstrates, the meaning of the term again changed considerably in public usage throughout the nineteenth century. Robert Rotenberg has suggested that by the end of this century, 'metropolis' had become firmly established in its 'original use in the European cultural field, designating the capital city of a colonial system'. ${ }^{30}$

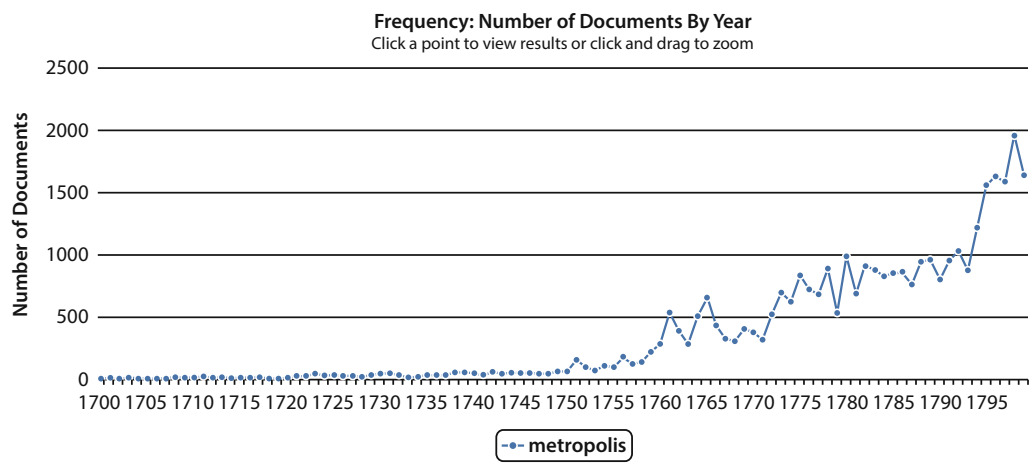

Figure 10.3 Number of documents for the search term 'metropolis' during the period 1700-1800. (Source: Burney Collection). 
Specifically London's growth and elevation in status as a metropolis amounted to what architectural historians have termed 'metropolitanism': a concerted effort to reshape prominent cities into dominant 'imperial commercial centres'. ${ }^{31}$ Metropolitanism, Rotenberg claims, occurred through the spatial and architectural restructuring of cities and the emergence of new representational spaces. The example of the London of the Future publication illustrates how architectural schemes were developed with the aim of conveying a sense of imperial grandeur and power. This type of metropolitanism, Rotenberg notes, remained the privilege of the dominant European empires and was made possible only through the economic exploitation of their colonies. Even so, he notes:

[t]he only cities that could afford such reshaping were those that benefited from the colonial economy, the metropoles of London, Paris and Vienna. Other colonial capitals, like Amsterdam, Brussels, St Petersburg, and Berlin, and industrial ports, like New York, would follow along as best they could, but always in the shadow of these three metropolises. ${ }^{32}$

While this account provides a powerful explanatory narrative for the changes that took place in London and other European cities, it bears pointing out that 'metropolitanism' manifested itself not only to different degrees, but also on the basis of different cultural contexts and constellations of empire. Paris, for example, did not seek to establish itself as a city of international trade as much as London. Its status as an imperial city derived less from its 'relationships with the wider world through trade or conquest' than from its achievements in the arts, and its status as the undisputed centre of intellectual thought and as a place for luxurious consumption for wealthy visitors, a show capital that was torn between 'conflicting expressions of capitalism and self-glorification'. ${ }^{33}$ Berlin, the capital of the 'belated nation', without major colonies, experienced its heyday as a metropolis only in the early twentieth century. ${ }^{34}$ Vienna, which Rotenberg names as the third of the major imperial cities, was the centre of a land rather than a sea empire, and accordingly derived its status from its European territories, rather than from overseas ones. It, too, depended on displays of spectacle and royal pageantry in order to project a sense of a 'cosmopolitan city of culture, luxurious and fashionable elegance'. ${ }^{35}$ This emphasis on consumption, luxury and fashion, as will be borne out in the following analysis, was less prominent in the case of London. 
Tracking the term over the course of the nineteenth century via the British Newspaper Archive reveals a notable increase in the use of the term 'metropolis' from the 1820s onwards, a time when the 'new buildings and streets of regency London so impressed observers from home and abroad' that the term metropolis became synonymous with the British capital, Richard Rodgers suggests. ${ }^{36}$ The increase in the use of the term also coincides with Britain's most intense phase of industrialization and urbanization, and London's growth to become the biggest city in the world.

Further, Andrew Lees has pointed out that during the 1820s the effects of urban growth were beginning to be increasingly discussed in books, pamphlets, periodicals and newspapers to a greater extent, which goes some way to explaining the increase in the use of the term during this time. ${ }^{37}$ Importantly, during these years and until about 1865, new administrative and institutional entities relating to the governance of London were established, which further explains the sharp increase in the use of the term during those years. In 1829 the 'Metropolitan Police' was founded, and in 1855 the 'Metropolis Management Act', passed by the British Parliament, established a London-wide body, the 'Metropolitan Board of Works', to co-ordinate and administer the planning for London's infrastructure. Additionally, in 1865, the new 'Metropolitan Municipalities Association' further institutionalized the governance of the City of London. ${ }^{38}$ All these new institutions and subsequent debates about their influence on the governance of the city proved to be crucial in solidifying London's self-representation as a metropolis. From the 1870s onwards, as Figure 10.4 clearly indicates, the use of the term fell sharply. Certainly, discussions over the administration and governance of London were still taking place throughout these decades, but the figures suggest that the quantity of the debates about the metropolis decreased considerably from the 1870s onwards. An in-depth analysis of the relevant contexts of the term in the PMGZ suggests that the following themes are prominent. ${ }^{39}$

Firstly, there is a high prevalence of terms such as 'metropolis+water', 'metropolis+management', 'metropolis+local management', and 'metropolis + metropolitan police', indicating that debates about management and administration, and discussions about water quality and supply were important, as were references to the police, which is unsurprising, given that reports on crimes and the work of the police constitute a daily staple of newspapers. It is notable that for the period 1870-9, the metropolis is initially frequently discussed in relation to an 'increase', the second most common cluster, but its frequency 


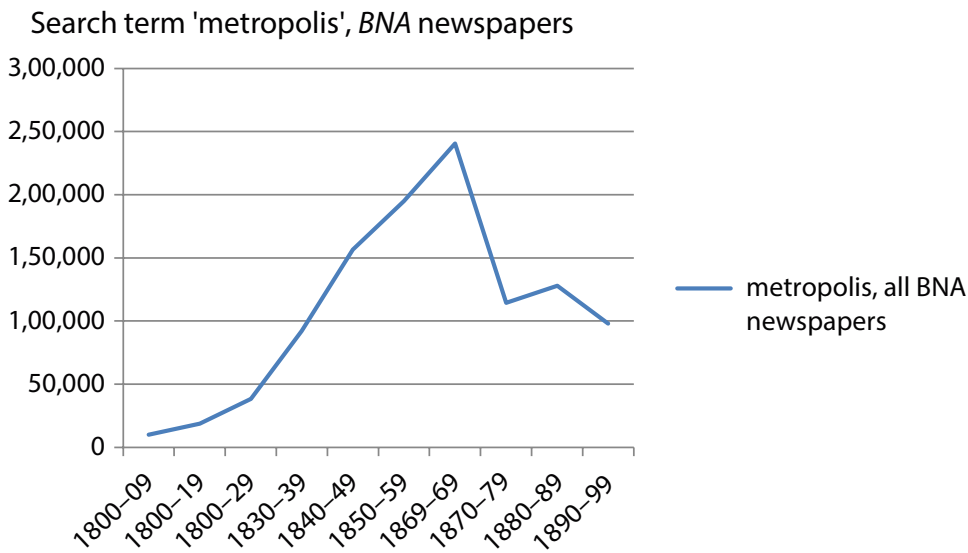

Figure 10.4 Absolute number of documents for the search term 'metropolis' during the period 1800-1900. (Source: British Newspaper Archive).

drops in 1880-9, and for the period 1890-9 this cluster does not appear at all. Thus, while the metropolis is initially strongly discussed in terms of growth and increase, this becomes less pronounced in the following two decades. Similarly, the cluster 'improvement' appears only in the first ten years, but is missing thereafter, which would suggest that discussions about the immense growth of the city and its improvements became less pronounced. Seemingly, while discussions about 'improving' the metropolis in relation to better sewage systems, housing and transport did continue, the terminology of 'improving' the metropolis, which emerged in the early nineteenth century, became less fashionable and fell out of use.

The metropolis also appears frequently in connection with 'railways'. Again, this is unsurprising, given that it was at this stage of the 1870s that the development of railways from the outlying suburbs and boroughs into London accelerated, enabling workers from afar to commute into the city, which had a profound impact on its social composition. ${ }^{40}$ In fact, Osterhammel maintains that the establishment of a well-connected railway system throughout the country from the 1850s and 60s onwards constituted one of the most important factors in altering the cityscapes of the nineteenth century cities to a profound degree..$^{41}$ Other prominent themes relate to 'health' and the 'water supply' in the metropolis, and to the continual fire hazards: 'fires in the metropolis' is a recurring cluster, together with other clusters relating to infrastructure, such as 'streets', 'sewage' and 'schools'. 
Other relevant developments over the three decades relate to London as a metropolis of entertainment: mentions of 'clubs in the metropolis' in the 1880s, and in the 1890s to 'music halls', but also 'visitors to the metropolis' are also on the increase, indicating that the metropolis is increasingly connected to ideas of entertainment and tourism. This is further supported by the fact that the terms 'night' and 'music' appear for the first time in the list of collocations for 1890-9. The connotation of the metropolis as a place of entertainment, music and spectacle becomes more pronounced in this last decade of the century, which is borne out by the fact that while music halls and places of entertainment obviously existed in London, the city had only thirty-three such halls in 1866, which amounted to only 10 per cent of existing halls nationwide. ${ }^{42}$ More elaborate, luxurious theatres and music halls developed only from the mid-1880s, the years in which the reopening of the London Pavilion in 1886 ushered in a period of faster growth of music halls, which had been more subdued up until then. ${ }^{43}$ This goes some way to explaining why those collocates that relate to entertainment and nightlife enter the terminology of the newspaper to a stronger extent at this later stage. Overall, the analysis demonstrates that the metropolis is discussed to a large extent in relation to issues of governance and administration, but also importantly to issues relating to location, transport and infrastructure. In addition, terms relating to measurements, especially to terms indicating the size of the metropolis, appear frequently.

The metropolis is also discussed in the context of 'money' and 'commerce', with references to businesses, business rates and rents. Interestingly, though, there are hardly any mentions of the metropolis as a place of wealth. Instead, it features recurrently in the context of 'poor' or terms such as 'pauperism', 'vagrants' and 'destitution', which indicate that the PMGZ did frequently report on the conditions of the poor and destitute in London. Historians such as Andrew Lees have pointed out that awareness and investigation of urban poverty received a new impetus during the 1880s and 1890s, in the wake of an economic slump which aggravated chronic housing shortages and chronic underemployment in certain industries. ${ }^{44}$ Given William Stead's aforementioned concern with the plight of the urban poor, this concern with poverty in itself is unsurprising. Even so, the absence of words such as 'wealth' or related synonyms - even just to draw a contrast between London's poor and the rich - is striking. By way of possible explanation for this absence, one might put forward that the jurisdiction of the Metropolitan Board of Works, and that of several other metropolitan bodies, excluded the City of London, where the main source of the city's wealth was generated. 
While we find increasing evidence of associations with leisure activities such as music halls and nightlife, direct references to consumption such as 'buying' or 'shopping', or to specific shops, do not appear at all, although the nature and extent of shops and consumption habits changed immensely in nineteenth-century London from small, directly owned shops at the start of the century, to different forms of retail establishments, including shopping arcades (1817) and the first department stores (1850s). While these had a noticeable impact on consumption patterns by creating a growing mass urban market, and in 'encouraging ever more people to visit London primarily for the purpose of shopping', London remains chiefly described as a place of commerce and finance rather than a luxurious shopping destination for the discerning nineteenth-century traveller, on a par with Paris or Vienna. ${ }^{45}$ Evidently, a different corpus composed of travel books and tour guides would provide very different results. For example, Gilbert's study of guidebook representations of imperial London suggests that within the literature of various travel guides, 'London's major shops, and particularly the great department stores, had long sold themselves as spectacles with a global reach'. ${ }^{46}$ Even so, the connotation of the metropolis as a place of conspicuous consumption does not yet feature strongly in the newspapers.

Having fleshed out the broad semantic terrain which the metropolis covers, the absences or omissions are revealing. With regard to the question of the imperial dimension of the metropolis it is noticeable that neither the cluster nor the collocation analysis has provided any recurring mentions of explicit references to other European metropoles such as Berlin and Vienna, or to American cities. None of the major cities such as Berlin, Rome or Vienna, or related adjectives such as 'German', 'Austrian' or 'Italian', are present as frequent collocates for the metropolis. The only exception is 'French', which appears as a fairly infrequent collocate with the metropolis during the period 1870-9. References to a 'German', 'Dutch' or 'Austrian' metropolis are completely marginal. As a way of cross-checking, a separate collocation analysis for the terms 'Berlin', 'Paris' and 'Vienna' confirms that these cities do not appear together with 'metropolis' or terms such as 'metropolitan' as relevant collocates. Given that references to relevant British commercial and financial centres such as Leeds, Manchester or Glasgow are also missing, this seems to suggest that the assignation of a 'metropolis' remains the preserve of the British capital city in the PMGZ, but is also applied to a very limited degree to Paris. This tendency is confirmed on a larger scale in the BNA corpus. Figure 10.5 indicates that the expression 'French metropolis' far outstrips mentions of a German, Dutch, Austrian, or even 


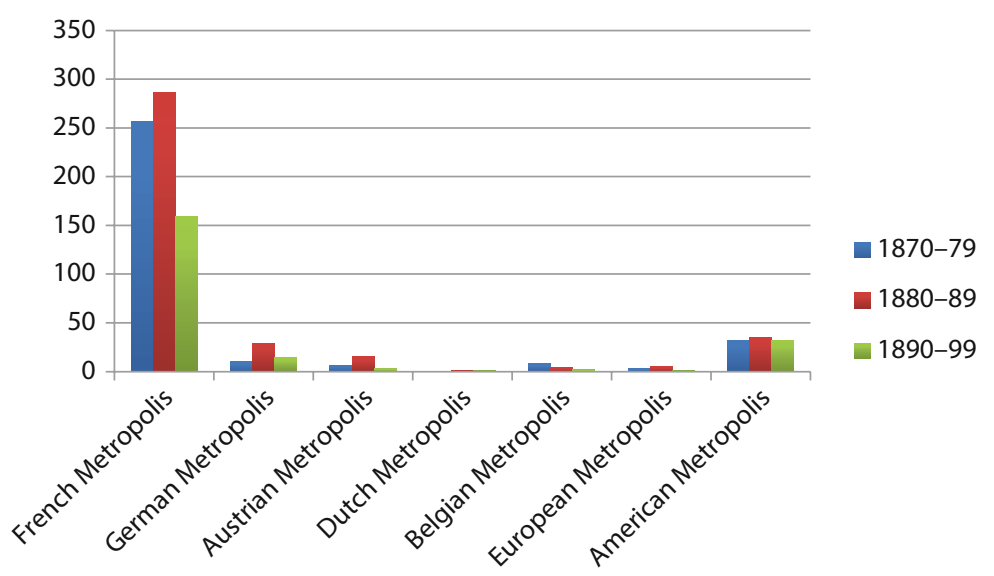

Figure 10.5 Absolute number of documents containing the search terms 'French', 'German', 'Austrian', 'Dutch', 'Belgian', 'European', 'American' metropolis during the period 1800-99. Calculated by the author from data derived from the British Newspaper Archive.

a more general 'European' metropolis. The 'American metropolis' is, however, more noticeable. Given that, as established previously, references to the size and to 'growth' or 'increases' appear to be important markers by which a metropolis is measured, one might suggest that since the newly emerging American cities were growing at a much faster rate than European cities in the late nineteenth century, they are designated more often as metropoles than the less dynamic European counterparts, with the exception of Paris.

\section{The imperial metropolis}

Are cities other than London referred to as a distinctly 'imperial metropolis'? Again, the BNA corpus indicates that the term is used very infrequently within the period in question here. Most often, this term refers to London, but other cities, such as Rome and Nice, are referred to in their capacity as 'imperial metropoles' in ancient times. References to contemporary imperial cities other than London include St Petersburg, Vienna as the seat of the Habsburg Empire, and Berlin the self-proclaimed kaiserliche Reichshauptstadt, 'imperial metropolis'.

Present-dayVienna is described as a beautiful example of a European imperial city, with a suitably representative centre, but lacking in dynamism. One article from the $P M G Z$ notes that 'Vienna, with its princely 
Ring and beautiful open parks, is indeed an imperial city; but nobody can walk through it without being oppressed by the idea that it is too large for its inhabitants and has had its day. The people do not seem to be able to fill the streets, and the theatres are often half-empty'. ${ }^{47}$ The article concludes that Vienna is outranked by other, more vibrant European cities such as Naples, Stockholm, Budapest and Constantinople.

Berlin, however, is credited as a newly emerging 'imperial metropolis' and a city of the future. The newspaper articles discuss the city's lack of affordable housing and the subsequent threat of disease that affects the poorer inhabitants of the 'imperial metropolis'. ${ }^{48}$ A later article from 1874 provides an extensive portrait of the emerging city and commends the recent steps that the city administration has undertaken to alleviate the housing crisis and to build suitably representative imperial buildings. Thus the newspaper reports that 'when the war of 1870-1 was over and Berlin was proclaimed Weltstadt by its enthusiastic citizens, the inhabitants of the Prussian provinces emigrated in shoals to the new imperial metropolis, eager to profit by the era of boundless prosperity which the newspapers announced was dawning for it'. ${ }^{49}$ Having overcome the initial housing crisis, the article continues, 'thousands of houses, built [in] the Parisian style, are rising in every direction, and today there is accommodation for all'. With Berlin's elevation in status, however, came a corrosion of moral propriety: 'Moralists are fond of railing against Paris, designating it as the Babylon of the nineteenth century, but in this respect Berlin and Vienna undoubtedly carry off the palm, and might fairly be called the modern Sodom and Gomorrah.' The article sets Berlin within the recurring themes affecting European cities of the time: housing, architecture and matters of public health, as well as the perceived threat of moral decay.

The theme of Berlin's growing stature as a 'capital of the empire' is reprised in an article from 1896 in the PMGZ. The correspondent notes that Berlin's 'greatest growth has doubtless been in the character of the capital of an empire, of the head-centre of an expanding national life. There is the most obvious proof of this in the handsomely built streets, the shops, hotels, cafes, restaurants, all of which have been modelled, in their brightness and grace, on the Paris rather than on the London model'. ${ }^{50}$ Again, it is the representative quality of its centre and the presence of modern entertainment venues in the all-important 'Parisian style' which, in the view of the author, elevate Berlin to the rank of a European metropolis. Arguably, we might read these as examples of Gilbert and Driver's aforementioned 'pan-European discourse' 
on the imperial city, in which cities are compared and ranked against each other on the basis of a shared understanding of what constitutes a modern metropolis. But is this a relevant context where London as an imperial metropolis is usually referenced? With regard to British newspapers, the following contexts appear dominant:

a) In a political context related to discussions about the British Empire (internationally);

b) In discussions concerning the United Kingdom, and relations between Ireland and England or Scotland and England (nationally);

c) In a historical context, comparing London to examples of ancient 'imperial cities', such as Babylon, Rome and Sparta;

d) In relation to infrastructure and architecture (locally).

One such example of an explicit reference to the city and its place within the project of empire occurs in an article published in the London Daily News from 1899, which reports on the 'Greater Britain Exhibition', an exhibition that was meant to showcase British imperial achievements. For the event, about 200 Zulus were brought from South Africa and housed in a small purpose-built village to form part of the exhibition. This crass display of 'natives' or 'imperial subjects' aroused indignation in the newspapers, but for altogether different reasons than a reader might think of today:

The natives themselves will scarcely have profited by their visit to the imperial metropolis. They have received far too much notice: and children are always spoilt by that process. They will scarcely carry back, we fear, to the neighbourhoods whence they came very favourable reports as to the dignity and wisdom of the British public. $^{51}$

An article from the Western Daily Press on the same topic, however, urges cooler heads to prevail in the face of this perceived indignation. The paper notes, 'it does not appear reasonable to offer indignant protest against their presence in the imperial metropolis. It is, indeed, not all complimentary [to] the people of the British metropolis to insinuate that by mere stay amongst them of a few months the representatives of the natives will be hopelessly demoralised. ${ }^{52}$ Both articles explicitly contextualize London's role here as the prime metropolis around which its colonies revolve. 
Of course, London was not only the metropolis in relation to its overseas colonies, but also vis-à-vis other parts of the United Kingdom, including Scotland and Ireland. This point is highlighted in a speech by Prime Minister Gladstone in 1893 in Edinburgh regarding the controversial Second Irish Home Rule Bill, which was picked up in several local and regional newspapers. Gladstone's speech touches on issues of legislation in response to demands for more autonomy for Scotland and Wales, and states that 'there is a legislative famine in the land. In connection with the claims of Scotland comes the case of Wales. Behind these stand the demands of England in the first instance, and the great imperial metropolis of London, with its four millions of people'. ${ }^{53}$ Other articles frequently highlight London as the oppressive, domineering imperial metropolis in relation to Ireland and Scotland, and provide a glimpse of the highly negative connotations which the term assumed in different contexts. ${ }^{54}$

Political contexts aside, the term is also used in the context of comparing and ranking London with the imperial cities of antiquity. An article from the London Standard, for example, describes London as follows:

The greatest city the world has ever seen is not only the centre of national beneficence, but is also an imperial metropolis. By all means let those give out of their abundance remember the poor; but let them not forget that there are other opportunities for the display of their munificence. The plutocrats of our modern Babylon have yet to recognise that London is the Sparta, which, as the Lacedemonian legislators impressed upon their people, it is their duty to adorn. ${ }^{55}$

London is compared here to the classical cities of antiquity and their evocative historical legacy: Babylon as a dysphemism for the large and ungovernable city, and Sparta as a positive model of social purity, discipline and purposeful conduct.

Finally, the 'imperial metropolis' is framed in relation to architectural ambition and achievement. An article from the PMGZ devoted to 'the great problem of the housing of the working classes in London' discusses the merits and drawbacks of different forms of housing schemes, which apply to those 'who are still dwelling in Central London, but whose poor tenements are gradually being swept away in the rebuilding of an Imperial Metropolis'. ${ }^{56}$ While taking the side of the poorer residents, it implies that an imperial metropolis invariably consists of a suitably representative centre, rather than one in which tenement buildings are located - bringing to 
mind Rotenberg's classification of the imperial metropolis as a project of spatial reorganization of European cities.

In summary, London as imperial metropolis is relevant in different contexts: firstly, in relation to the British Empire, for it is through London's description as a global metropolis that the British press constructs a notion of centre and periphery on a global scale. These asymmetries are also relevant on a national level, especially in the context of centre-periphery relations between England, Ireland and Scotland. Other relevant contexts refer to the spatial reorganization of the city and the imperial cities of antiquity. As the collocation analysis of the EEBO corpus for the seventeenth and eighteenth centuries indicates, the use of the term metropolis in relation to ancient and historical cities has a long tradition. Throughout the nineteenth century, the term became increasingly common in general usage and its meaning broadened. As the study of the PMGZ has shown, the metropolis became used in relation to a wide field of topical debates about the city: its administration and police, its infrastructure, the quality of its water supply, the risk of fire and London as a place of musical and theatrical entertainment. On rare occasions, London is compared even in the late nineteenth century to the imperial cities of antiquity, suggesting that this remains a reference point as a way of channelling an image of the modern-day metropolis. Importantly, however, the use of the term 'metropolis' is reserved chiefly for London and, to a lesser degree, Paris, reifying the perception that London and Paris were the only 'real' imperial metropoles in a league of their own.

In regard to the departure point for this study about the distinctly European dimension of the metropolis, this suggests that such a context was not a consistent theme in British newspapers at the time, and was more likely prominent in more specialist books - arguably elite or niche publications - rather than in everyday, 'mundane' newspaper reports. Certainly, the PMGZ did report widely on events from other European and North American cities; while it was a London-based newspaper, its outlook was far from provincial. Even so, the metropolis was firmly set within British national preoccupations of the time such as the British Empire, or in relation to Ireland and Scotland. In the high imperial phase of the late nineteenth century - a time also of increasing nationalist sentiment in the popular press - imperial London was therefore presented to its readers as a metropolis quite unique, rather than in conversation with its European counterparts. 


\section{Notes}

1. Jürgen Osterhammel, The Transformation of the World: A Global History of the Nineteenth Century. Princeton: Princeton University Press, 2014.

2. See: J. R. McNeill and Peter Engelke, 'Cities and the Economy', in Akira Ireye, ed., Global Interdependence: The World after 1945. Cambridge, MA: Belknap Press of Harvard University Press, 2014.

3. Peter Clark, European Cities and Towns: 400-2000. Oxford: Oxford University Press, 2009, 4.

4. Pierre-Yves Saunier, Transnational History Theory and History. Basingstoke: Palgrave Macmillan, 2013, 113.

5. Pierre-Yves Saunier and Shane Ewen, 'Global City, Take 2: A View from Urban History', in Pierre-Yves Saunier and Shane Ewen, eds, Another Global City: Historical Explorations into the Transnational Municipal Moment, 1850-2000. Basingstoke: Palgrave Macmillan, 2008, 1-18.

6. Osterhammel, The Transformation of the World, 264.

7. Felix Driver and David Gilbert, 'Imperial Cities: Overlapping Territories, Intertwined Histories', in Felix Driver and David Gilbert, eds, Imperial Cities: Landscape, Display and Identity. Manchester: Manchester University Press, 1999, 3.

8. Felix Driver and David Gilbert, 'Capital and Empire: Geographies of Imperial London', Geojournal, 51 (2005): 23-32, quotation from 23.

9. Felix Driver and David Gilbert, 'Capital and Empire', 23.

10. British Newspaper Archive (BNA) http://www.britishnewspaperarchive.co.uk/ [accessed 15 June 2017]; Seventeenth and Eighteenth Century Burney Collection Newspapers (Burney Collection) https://www.bl.uk/collection-guides/burney-collection [accessed 21 June 2017]; Early English Books Online corpus (EEBO) http://gateway.proquest.com.libproxy.ucl.ac.uk/ openurl?ctx_ver=Z39.88-2003\&res_id=xri:eebo\&rft_id=xri:eebo:screen:basic_search [accessed 15 June 2017].

11. The Pall Mall Gazette (PMGZ) is part of the BNA. The British Library has kindly granted access to the full-text version of the newspaper. Laurence Anthony, AntConc (Version 3.4.3) [Computer Software]. Tokyo: Waseda University (2014). Available from http://www.laurenceanthony.net/software/antconc/ [accessed 21 June 2017].

12. Osterhammel, The Transformation of the World, 263.

13. Jonathan Schneer, London 1900: The Imperial Metropolis. New Haven: Yale University Press, 1999, 4.

14. Wiliam Cobbett, Rural Rides, 1830; edited with an introduction by George Woodcock. Harmondsworth: Penguin, 1967, 42.

15. London Standard $(L S), 16$ January 1882, BNA. All subsequent newspaper quotations are from the BNA.

16. Derek Keene, 'Cities and Empires', Urban History, 32 (2005): 8-21, quotation from 13.

17. Keene, 'Cities and Empires', 19.

18. See Charles Masterman, ed., The Heart of the Empire: Discussions of Problems of Modern City Life in England with an Essay on Imperialism. London: Unwin, 1902.

19. Lord Meath, 'London as the Heart of the Empire', in Sir Aston Webb, ed., London of the Future. London: Unwin, 1921, 251-61, quotation from 253.

20. Jonathan Schneer, London 1900, 10.

21. David Gilbert, "'London of the Future": The Metropolis Reimagined after the Great War', Journal of British Studies, 43 (2004): 91-119, quotation from 104.

22. Andreas Geppert, Fleeting Cities: Imperial Expositions in Fin-de-Siècle Europe. Basingstoke: Palgrave Macmillan, 2010, 143.

23. Sydney Webb, The London Programme. London: Swan, Sonnenschein \& Co., 1891, 7.

24. Peter Robins, 'The Death of Newspapers, 1921: London Evening Massacre', Guardian, 23 September 2009 http://www.theguardian.com/media/organgrinder/2009/sep/23/ death-of-newspapers-1923 [accessed 15 April 2017].

25. For more on William Stead and the history of the Pall Mall Gazette see George Boyce, James Curran and Pauline Wingate, eds, Newspaper History from the Seventeenth Century to the Present Day. London: Constable, 1978; Joel Wiener, The Americanization of the British Press, 1830s-1914: Speed in the Age of Transatlantic Journalism. Basingstoke: Palgrave Macmillan, 2011; Robert P. Frankel, Observing America: The Commentary of British Visitors to the United States, 1890-1950. Madison: University of Wisconsin Press, 2007, 17-51. 
26. Osterhammel, The Transformation of the World, 263.

27. See Anna L. Stoler and Frederick Cooper, 'Between Metropole and Colony: Rethinking a Research Agenda', in Frederick Cooper and Ann Laura Stoler, eds, Tensions of Empire: Colonial Cultures in a Bourgeois World. Berkeley: University of California Press, 1997, 1-59.

28. Richard Rodger, 'The Significance of the Metropolis', in Dorothee Brandt, Sasha Disko and Georg Wagner-Kyora, eds, Thick Space: Approaches to Metropolitanism. Bielefeld: Transcript, 2012, 85-103.

29. The collocation analysis was performed using the CQP tool. Andrew Hardie: Corpus Query Processor, Lancaster University) [Computer Software], https://cqpweb.lancs.ac.uk/ [accessed 30 April 2017]. For more documentation on the CQP tool, see Andrew Hardie, 'CQPweb: Combining Power, Flexibility and Usability in a Corpus Analysis Tool', International Journal of Corpus Linguistics, 17:3, 380-409.

30. Robert Rotenberg, 'Metropolitanism and the Transformation of Urban Space in Nineteenth-Century Colonial Metropoles', American Anthropologist, 103 (2001): 7-15, quotation from 7.

31. Robert Rotenberg, 'Metropolitanism', 9.

32. Robert Rotenberg, 'Metropolitanism', 9.

33. Claire Hancock, 'Capitale du Plaisir: The Remaking of Imperial Paris', in Driver and Gilbert, eds, Imperial Cities, 64-78.

34. Tim Opitz, 'The Global, Imperial Metropolis: Ideas from 1873 Berlin', in Brantz et al., eds, Thick Space, 357-77.

35. Jill Steward, 'The Potemkin City: Tourist Images of Late Imperial Vienna', in Driver and Gilbert, Imperial Cities, 78-96.

36. Richard Rodger, 'The Significance of the Metropolis', 95.

37. Andrew Lees, Cities Perceived: Urban Society in European and American Thought, 1820-1940. Manchester: Manchester University Press, 1985, 5.

38. See Ken Young and Patricia Garside, 'Magnitude and Mist: The Politics of Metropolitan Growth 1837-1880', in Metropolitan London: Politics and Urban Change 1837-1981. London: Edward Arnold, 1982, 11-22.

39. The analysis used the AntConc tool to conduct a cluster and collocation analysis of the term metropolis. The cluster analysis provides us with a contiguous sequence of recurring words, which form an expression. The setting for the analysis was set to a minimum of 2 to a maximum of $5 \mathrm{n}$-grams to the left (proceeding) and right (preceding) of the term, and only included those n-grams appearing at least five times. For the collocation analysis, the standard span of words was set to five words to the left and to the right of the term, with a minimum frequency of ten occurrences. The collocation analysis was conducted twice, once ranked by frequency, and in the second iteration arranged by statistical strength of the collocation based on the Mutual Information Score (MI Score). While the frequencies provide a good overview of the different terms and wordfields around the term metropolis in the Pall Mall Gazette, the MI score provides additional insight into actual strength of the collocation as it is calculated on the basis of the number of times two given words occur together versus the number of times they occur separately. The higher the number of the Mutual Information Score, the stronger the collocation. For a more detailed description of the statistical background to the MI Score see: Laurence Anthony, Douglas Biber, Susan Conrad and Randi Reppen, 'Statistical Measures of Lexical Associations', in Corpus Linguistics: Investigating Language Structure and Use. Cambridge: Cambridge University Press, 1998, 265-8.

40. As pointed out by Young and Garstable, p. 16.

41. Osterhammel, The Transformation of the World, 301.

42. Michael Ball and David Sunderland, An Economic History of London, 1800-1914. London: Routledge, 2001, 159-61.

43. Michael Ball and David Sunderland, An Economic History, 160.

44. Andrew Lees, Cities Perceived, 106-35.

45. Michael Ball and David Sunderland, An Economic History, 141.

46. David Gilbert, "'London in All its Glory, Or How to Enjoy London”: Guidebook Representations of Imperial London', Journal of Historical Geography, 25 (1999): 279-97, quotation from 290.

47. Pall Mall Gazette, 21 July 1896, BNA.

48. Lancaster Gazette, 29 June 1872, BNA; Falkirk Herald, 27 June 1872, BNA.

49. Yorkshire Post and Leeds Intelligencer, 12 December 1874, BNA.

50. Pall Mall Gazette, 11 November 1896, BNA. 
51. London Daily News, 5 September 1899, BNA.

52. Western Daily Press, 9 May 1899, BNA.

53. Lincolnshire Echo, 28 September 1893, BNA.

54. Western Times, 30 March 1880, BNA.

55. London Standard, 16 January 1882, BNA.

56. Pall Mall Gazette, 4 August 1899, BNA. 


\section{1}

\section{Mediating Hybrids: Consumption and Transnationality}

Hermione Giffard

\section{Introduction}

Despite its local nature, consumption is an important activity for establishing an individual's sense of the global. Looking into the twentieth century allows us to chart a new relationship of the global and peripheral. Indeed, consumption is an activity that took on even more intensity in the twentieth century, while global supply chains affected ever more people. Because the subject of this chapter - multi-national companies - became particularly powerful in the twentieth century, and because consumers in the peripheries eventually gained financial clout - and thus a new kind of influence - this chapter focuses on the later century. In this it complements the earlier focus of the other chapters because it lets us see clearly relationships that were less visible in earlier periods when branding was not aimed at the individual consumer.

As companies that sold goods in different national contexts in the late twentieth century, multi-nationals, were particularly significant in establishing individual views of the global because through their advertisements they combined local understandings of consumption with visions of the global. Multi-nationals were important mediators between the local and the global; they spread peculiar things that do not fit neatly into the categories of transnational history: hybrid images, or locally tailored impressions of the global.

There have always been more people in the periphery than the centre and so we need to take seriously the ways in which they exerted influence on the centre. Consumption was a key way in which peripheries could influence centres - at least when their consumption became 
more global. The timeframe that this chapter will focus on, the 1950s and 1960s, makes it fitting to talk about asymmetries and their ramifications rather than periphery and centre: asymmetries of power, of size and of wealth. This chapter will focus particularly on asymmetrical encounters in the realm of consumption between providers and consumers.

Consumption is particularly interesting in this regard. It is uniquely placed to reverse asymmetries of power, due to the fact that providers are influenced by consumers. At the same time, smaller countries have reversed asymmetries by creating multi-nationals, thereby influencing world markets beyond what their size might lead scholars to expect. Of particular interest here are two types of asymmetry: firstly, that between consumer and supplier; and secondly, that between small countries, with few consumers but multi-nationals, and large countries, with many consumers and few multi-nationals.

Thus this chapter is not focused on how objects move between places, but rather how influence, through consumption, can travel against asymmetries - particularly from 'weaker' consumers to 'stronger' consumers through multi-national companies. Like so many things, this is fundamentally a question of how the global and the local interact. In the two examples of Dutch multi-national companies studied here, Heineken and Unilever, two different types of interaction between global and local are evident. Both underline asymmetries: after the Second World War, Heineken chose to advertise a single product around the world, using local visions of the global to sell its single product, while Unilever focused on catering to national markets, using the local to give the global legitimacy. Although Heineken's strategy is that most frequently connected with the idea of homogenization through globalization, this is perhaps too simple an analysis. Unilever caters to the local, but uses it to sell products of global concern. At the same time, however, the company offers a powerful channel for the local to influence the global because it operates across markets around the world. Heineken, meanwhile, uses local semantic codes to craft its supposedly hegemonic image of the global for each market.

Whether companies generate desires among consumers or respond to them is a point of contention in the literature about consumption. One recent suggestion by A. A. A. de la Bruhezé is to consider these processes as intertwined. Companies can be seen in this view as 'mediators' between consumers and producers. ${ }^{1}$ Any action 'creating' desire among consumers reinforces the asymmetry of producers and consumers because the company is stronger, whereas 'following' reverses it because the stronger party (the company) fulfils the wishes of the weaker party (consumers). 
Most importantly, mediation suggests a two-way flow between groups with different (but not necessarily independent) interests. Multinationals, too, can usefully be understood as mediators of global images.

Visions of the global were always mediated. Even when this apparently started to end - around the time of the first world's fair, held in 1851 in the Crystal Palace in London, the 'Great Exhibition of the Works of Industry of All Nations'- it was changing rather than disappearing. World's fairs functioned as a form of local re-enactment of the global, where foreign places were represented in familiar terms to local people. In so far as states or nations created pavilions at world fairs dedicated to their industrial or cultural output, the fairs served to link consumers and producers, but the message was still mediated in a way that became unnecessary once the rise of tourism and television enabled people to make images of 'the global' for themselves (and test received images). Yet along with reading (mediated by the author), images (mediated by artists), or gossip (mediated by travellers and non-travellers), world's fairs (or 'Expos' from 1967), and what came after them, were just differently mediated visions of the global - and were treated that way by consumers. Despite being open to exotic goods from abroad, people always consumed renditions of the global within a local context. The global began as a mix of images of foreign places before morphing into a broader concept; the changing nature of trade, including the rise of multi-national business enterprises, was an important contributor to this shift. The authors, if not the power, of these mediated images changed over time.

The transnational nature of consumption raises many questions about its importance in creating the categories of the global and the local. Consumption has been transnational for a long time; as a consequence, although the nature of consumption has changed, openness towards the global through consumption has remained. Trade has always been important to shaping individuals' views of the global. In times when the only contact between places came through diplomacy and trade, the first image that other countries had of the global, of foreign places - in every meaning of the word - were images borne by goods. Kristin Hoganson has argued that in the nineteenth century consumption created 'imagined communities' that transcended political boundaries. ${ }^{2}$ Frank Trentmann pushes the date of the first consumer society much further back. ${ }^{3}$ Several historians have argued that many of the earliest examples of transnationality come from trading networks. And more importantly, knowledge (both formal and informal) of foreign cultures and social mores frequently followed trade. ${ }^{4}$ It was the naturally transnational ties of trade 
that were interrupted by the rise of nationalism, which caused some countries to sever such ties for ideological reasons or to retreat into the trade networks of empire. The late twentieth century saw the reinstatement of these ties, however, with the subjugation of nationalism to economics and the victory of the ideology of free trade. ${ }^{5}$ Politics has always been able to shape consumption. ${ }^{6}$

The idea of consumer activism - the achieving of social rather than political ends through consumption - is a recent (i.e. late twentieth-century) idea ${ }^{7}$ because it rests on an awareness of the global nature of supply chains and the power of consumers that only evolved recently. It is important to distinguish this from the notion of the consumer as a political actor, which has a longer history. ${ }^{8}$ Indeed, the importance of consumers as a political identity, the notion of the 'consumer citizen', has successfully been applied to the past. ${ }^{9}$ Yet the idea that 'the most common way we participate in social activism is by buying something ${ }^{10}$ depends on a couple of mental changes that took time to come about. The most important is an awareness of the global interconnectedness of supply chains, which was gradually constructed in the second half of the twentieth century. This particular notion of the global is one in which individuals (can) take much more responsibility for what goes on in far-away places. So, as Roland Robertson has cautioned, we should not equate the global interconnectedness that has always been around with globalization as understood today, which brings with it a different consciousness of the relation between the local and the global. ${ }^{11}$

It is saying nothing new to assert the importance of the local for consumption. Despite contributing to consumers' understandings of the global, consumption is a fundamentally local activity. Ilja van Damme has argued that consumers in the early modern period in Antwerp relied mostly on trusted sellers; the seller, rather than any notion of early-modern branding, was relied on for information about different products. ${ }^{12}$ This mediation of the global by the local made it fairly irrelevant to consumers where a product came from. Trust was a matter between a salesman and his customer in a local transaction that took place in person.

In addition, there have been many studies of how local meanings were used to understand foreign objects, and of agendas that were transported via transnational links (though generally not of trade). An anthropological study of the airport in Bangkok, for example, has looked at how local meanings were overlain on an object that served an international elite. ${ }^{13}$ While the highly modern Suvarnabhumi Airport, which opened for international travel in 2006, connects Thailand to a global infrastructure of travel, like most airports it draws its workers from the 
local population. These workers bring local lore to the airport. Because according to local lore the Suvarnabhumi Airport is haunted by bad spirits, sacrifices are made to the god responsible for safe travel, to ensure successful flights. ${ }^{14}$ For the travellers passing through the airport, however, the global-ness of international travel is interrupted by the airport's attempt to use local uniqueness to combat international uniformity by calling on elements of local culture and folklore. For those travellers for whom Thailand is a waypoint, part of their image of the global will remain mediated by the creators of the airport. Similarly, farmers in French Sudan used imported French machines, not to produce an idea of the global, but to reinforce local systems of worth: farmers who could use French tractors were deemed more masculine than those who did not have them. ${ }^{15}$ In this way, foreign objects can be foils for the local as much as reflections of the global.

Yet the meanings or uses of specific objects are less important here than the empirical evidence of how multi-national companies, understood as mediators, used images of the global and the local to further their business interests. This study is interested in the shaping of images before consumption - i.e. images that influenced the act of acquisition, and whether or not they influenced the meaning of consumption itself. Multi-nationals are heavily implicated as mediators responsible for constructing meanings of the global, because for locals they are often the primary representatives of it. Through their global reach, too, multi-nationals allow local customs to influence the behaviour of people in other places, because multi-nationals are holders and communicators of knowledge built up in many separate markets. The focus here will be less on the meanings attached to specific goods than on more general concepts and their use to reverse typical asymmetries.

Heineken and Unilever are two multi-nationals based (at least partly) in the Netherlands. They represent ideal cases for the purpose of this study, because they demonstrate how multi-nationals have worked against asymmetries in order to forward their business interests. Asymmetries, while imperative for historians to be aware of, need therefore to be treated with some caution. This chapter focuses on the contrast between the post-war advertising strategies chosen by Heineken and Unilever, and their significance for shaping meanings of the global. The two companies sell very different products, which was important for the two companies' ultimate decision regarding the place of the global in their respective business strategies. Heineken ended up selling a global product using local images of the global, while Unilever used the local in order to render the global more familiar to its local customers. 


\section{Heineken}

After the Second World War, Heineken, a brewer based in the Netherlands, set out to boost its fortunes by selling a single product to consumers around the world. In its appeal to the global, Heineken was not alone. Western-style barley beer was already popular around the world. Although there were other contenders as well, 'across the colonized or post-colonial world beer came to be seen as the water of modernity. ${ }^{16}$ This meant that foreign conquerors set up new factories to serve themselves. But their work also served to associate beer drinking with success and a sense of superiority. This was something that Heineken could take advantage of and reinforce after the war: the notion of a recipe for success was desirable. Part of the attraction of beer, which then was already a global product insofar as it was drunk around the world, was that consumers could show a sophisticated knowledge of foreign tastes through their consumption patterns. A national brand of beer became a symbol of and vehicle for nation-building. ${ }^{17}$ Heineken could take advantage of these associations: the taste for Western-style beer, the desire for success and cosmopolitanism, and local industrial frameworks established to make beer. In this way, Heineken used a beverage that had been an early winner of globalization to drive globalization forward.

Heineken's advertising strategy was naturally focused on associations with its beer, and here the global was a key element. To be of use for Heineken, the global had to be desirable, and associated with success and modernity. Thus the notion of the global that was promoted by Heineken was a very particular one. Ironically, these messages stressed the beer's global appeal, but at the same time they were tailored to local consumers and thus reflected local associations and tastes. Although Heineken's strategy could be accused of promoting homogenization, in so far as its global product was everywhere the same, its success depended on a close understanding of the local. Thus the decision to appeal to global consumers meant that the company had to appeal to consumers on all parts of an asymmetrical spectrum at the same time.

The company's earliest approach to internationalization was taken under the leadership of Alfred Henry 'Freddy' Heineken, the grandson of the founder of the Heineken brewery, who started working for the company in 1940. Freddy rebuilt the company into a global brand after the Second World War. As part of this strategy, he decided to focus on a single product. This decision reinforced the pre-existing global tropes that Heineken's advertising strategy had previously exploited. (The only 
exception was the United Kingdom, where at that time lager beer was not yet established. ${ }^{18}$ ) For some, the global was aspirational; for others it was familiar. The innovative concept behind Heineken's advertising strategy was that it could address both groups. If Heineken was everywhere the same, it could be relied upon to give the taste of home for global travellers; ironically then, a global reach offered access to the familiarity of the local everywhere. For others, drinking Heineken meant joining a refined, global community.

Meanwhile, immediately after the war, Heineken was not yet a globally recognized brand. In 1953, the company commissioned seven international artists to create advertisements for the company to promote local consumption on a global scale. ${ }^{19}$ As part of this campaign it asked the Dutch public to pass a vote on the best images produced. ${ }^{20}$ The example shows that for the Dutch market the company chose to emphasize the brand's global appeal, which at this point was more an aspiration than a reality. Heineken constructed an image of global homogeneity - the (same) beer drunk around the world - based on a local peculiarity (that would be attractive to the Dutch market). Meanwhile, the campaign used readily recognizable icons of foreign cultures - global differences - in order to sell a single homogeneous product across the globe. The campaign underlined that the beer fit seamlessly into any lifestyle; and that the global was far from anodyne, easily fitting into any local setting.

If one examines illustrations from this campaign, it seems striking how relatively inaccurate some of the drawings were (the more foreign the culture, the less accurate, one might generalize). It is important that these were images drawn by foreign artists but judged by and sold to Dutch people: they are therefore original representations of what Dutch people in the 1950s thought of foreign countries. The inaccuracies of some of the images would have made little impact on a Dutch audience. For instance, in the Japanese example, the image has been reversed (probably for purely aesthetic reasons), rendering the Japanese type unreadable; and it includes geishas, who would not have consumed alcohol, were a readily recognized image of Japan. ${ }^{21}$

The fact that these images are a local vision of the global - Dutch advertisements aimed at Dutch consumers - demonstrates another layer of relating the global to the local. Is it possible to have a vision of the global that is not on some level connected to a location? Or does being a global citizen mean forming an image of 'the global' from multiple local images? At the same time as creating a global brand in the Netherlands, Heineken marketed its beer abroad as a particular item of Dutch culture. ${ }^{22}$ In Australia, for example, advertisements made clear that the beer was a 
specifically 'imported' or foreign product. Whereas for Dutch consumers, the company chose to advertise the beer's international credentials, for Australian consumers, it advertised its Dutch credentials. In both cases, however, the iconography used at the start of Heineken's campaign relied on a vision of the global and its relationship to Dutch beer.

A newspaper advertisement prepared by Heineken for Dutch consumers in 1959, when the company was more established on a global scale, likewise serves to illustrate the firm's strategy to appeal to global consumers. The text of the advertisement, published on 19 June 1959, reads: 'Why do people drink Heineken's beer? ... Because Americans, Italians and Irish and Frenchmen and Liberians and Icelanders drink it? Not for that reason! ... People drink Heineken's beer because they know for sure that there's no tastier beer in the world than that from Heineken! Heineken: the most tapped, anywhere! ${ }^{23}$ The logo, 'the most tapped, anywhere', would stay with the company for at least two decades, based on the fact that advertising the beer's global appeal was a successful approach to boost sales. Thus what was important was not Heineken's view of the global, but that of Heineken's consumers in local markets. The fact that Heineken's beer was not associated with any specific group of consumers or nationality was crucial to the decision for global appeal. Exceptional references to the beer's Dutch background only reflected the company's origins and the nation's trading history.

How the company chose to structure its global market - by continents, for example - reflects ideas of the global but also different landscapes of production. ${ }^{24}$ It is important to remember that the company's advertising, which invoked familiar stereotypes of foreign cultures, was largely divorced from its production supply chains, which continued to be local. At the same time, the company imbued its product with a global character of its own. In the 1950s, the company already owned breweries in other countries, producing the same Heineken products, to be sold locally under the multi-national's name. ${ }^{25}$ By means of a local infrastructure, a global product was made available to consumers in new places.

The global provision of its beer, made possible by the local infrastructure bought up and operated by a multi-national company, was separated from the cultural hybrid created by Heineken's marketing department, which used cultural differences in order to argue that its global product could be amalgamated into any and every local culture. In the service of the global, the local was caricatured; and those caricatures were reinforced through further exposure and through association with a global product. 


\section{Unilever}

Unilever adopted a different strategy, being a multi-national from the start, co-headquartered in the United Kingdom and the Netherlands. It was formed by the merger of a British and a Dutch company in 1929. Like Heineken's, the firm's marketing strategy was independent of its manufacturing, because Unilever had factories around the world. ${ }^{26}$ At first the company sold food, before branching into soaps and other cleaning products - all with an emphasis on use in the home.

Despite these different origins, Unilever's strategy was similarly dependent on its global reach. The company's role of mediating between producers (global) and consumers (local) forced it to come to grips with local peculiarities. Meanwhile, unlike Heineken, Unilever ended up establishing local branches that produced 'different, nation-specific products' and even products for smaller markets known as 'segmented national markets'. ${ }^{27}$ Reasons for its different marketing strategy can be found in the fact that its products were best served by trust in the proximity of the home, rather than by images of power and success. The company learned to appreciate the specific characteristics of local markets after its original marketing strategy failed.

Following the Second World War, Western Europe represented for Unilever a land of opportunity, and at first the company approached it as a single market. To this end, in the 1960s, it established a single 'European' research and development lab. However, the new potato snacks produced by its research lab, despite great initial promise, were largely rejected by the Dutch market. ${ }^{28}$ This experience contrasted with the successful introduction by Calvé (a subsidiary of Unilever) of a new peanut snack, the borrelnoot, in the 1970s. The failure of Unilever's potato snack, juxtaposed with Calvé's success, convinced the company of the benefits of establishing nation-specific research facilities to respond to local culinary customs. ${ }^{29}$ Yet this local specialization relied on Unilever's global outreach. In a kind of 'reverse globalization', the multi-national used its economic power to cater for specific national tastes and cultures, thereby shaping and reinforcing local distinctions with the help of its products. Despite its initial strategy of trying to impose products on local customers - which might have seemed more profitable for a multi-national business - Unilever ultimately settled on the strategy of catering to the local.

Unilever's change of strategy meant that its global reach would empower consumers in very specific ways. The company's global reach meant that lessons learned in one market, such as the importance of local 
research facilities, could be transferred to other markets. In the context of this book's debates, this strategy is of particular interest, because the company's marketing strategy stands for a flow against the asymmetry of power: solutions initially developed for less powerful consumers came to influence patterns of consumption of the more powerful consumers. Multi-national companies, in providing a link between different national markets, make the local dependent on the global in yet another way.

Unilever's approach to global expansion was also facilitated by the growing importance of consumer research in the mid-twentieth century. Management experts convinced companies of the benefits of understanding locally specific patterns of consumption; science and technology provided the means to do this. This field of marketing research has changed dramatically over the past fifty years, allowing corporations to study consumers in local markets and to transfer their insights globally. ${ }^{30}$ Research on consumption meant that multi-nationals were forced to take the local seriously in a way that they could not before. The capitalist desire of boosting sales thus reversed power asymmetries by forcing producers to cater to consumers in peripheral countries.

The local dimension of consumption, however, was and is particularly important to Unilever, for it was the local that created consumers' trust. Unilever thus developed a global marketing strategy based on local trademarks that responded to local concerns. At the same time, Unilever was in a position to blend the local brands with the company's global reach. A good example is Unilever's ice cream strategy. The world's largest producer of ice cream in the 2010s, the company created logos for its products that combined local names with a globally identifiable image. Each icon is instantly recognizable. ${ }^{31}$ Unilever seamlessly combined the trust and familiarity of a local brand with the trust derived from the quality standards of a multi-national.

\section{Conclusion}

In the mid-twentieth century, as targeted advertising became more ubiquitous, multi-national companies became crucial mediators between the global and the local as a strategy to increase their sales. Companies promoted local visions of the global, while also amalgamating the global to reflect insights from local markets. The two companies studied here, Heineken and Unilever, reached an impact beyond the size of their home countries by successfully creating a hybrid of global and local meanings that, backed by the authority of a powerful company, they spread to many 
different countries. Their example shows how multi-national companies reversed asymmetries intrinsic in global markets, affecting in particular concepts of national power. In this case the Netherlands offers a particularly striking example of a 'small' country assuming global economic power. Both companies were compelled to look abroad to find larger markets than those accessible at home. They show how smaller nation states might take a greater interest in global markets, especially because their home markets are relatively small. This context answers the additional question why small countries might be over-represented in the field of multi-nationals. Their companies work hard to gain global influence; but their power can only be wielded as long as local consumers respond to it.

Moving to a more abstract level of debate, the case study shows that globalization can reverse spatial asymmetries. Asymmetries in one field may not correspond to asymmetries in another. Some agents gain from certain aspects of globalization, regardless of wider implications that might be judged negatively. Overall, this chapter shows how in the twentieth century consumers (rather than nation states) have been empowered by consumption. Their voice also left an impact on consumers in other places. Consumption in the mid-twentieth century gave the local the power to influence the global.

The effects of globalization on trade and consumption are not easily predictable and do not follow a single model. There are many different avenues where the local fuses with the global, offering ramifications for individual understandings of the global. Despite the local consumer's impact on marketing strategies, exemplified in the two case studies, companies are not innocent bystanders in the creation of images of the global. They actively create meanings, shaping as much as following markets. The global, a contested rather than obvious category, is ultimately built on hybrids of local meanings and is itself a local concept.

\section{Notes}

1. A. A. A de la Bruhezé, 'Manufacturing Snacks and Snakers: Unilever and Dutch Snack Consumption,' in Manufacturing Technology, Manufacturing Consumers. Amsterdam: Aksant, 2009, 183-209, p. 184.

2. Kristin L. Hoganson, Consumers' Imperium: The Global Production of American Domesticity, 1865-1920. Chapel Hill: University of North Carolina Press, 2007, 58-67.

3. Frank Trentmann, Empire of Things: How We Became a World of Consumers, From the 15th to the 21st Century. London: Allen Lane, 2016.

4. See Pamela Smith, 'Knowledge in Motion: Following Itineraries of Matter in the Early Modern World', ans Harold Cook, 'Creative Misunderstandings: Chinese Medicine in SeventeenthCentury Europe', in Daniel T. Rodgers, Bhavani Rama, and Helmut Reimitz (eds), Cultures In Motion. Princeton: Princeton University Press, 2014, 109-33 and 215-40. 
5. Frank Trentmann, Free Trade Nation: Commerce, Consumption, and Civil Society in Modern Britain. Oxford and New York: Oxford University Press, 2008.

6. John Brewer and Frank Trentmann (eds), Consuming Cultures, Global Perspectives: Historical Trajectories, Transnational Exchanges. Cultures of Consumption Series. Oxford: Berg, 2006, 10.

7. Eleftheria J. Lekakis, Coffee Activism and the Politics of Fair Trade and Ethical Consumption in the Global North: Political Consumerism and Cultural Citizenship. Basingstoke: Palgrave Macmillan, 2013; Roopali Mukherjee and Sarah Banet-Weiser, Commodity Activism: Cultural Resistance in Neoliberal Times. New York: NYU Press, 2012.

8. Roberta Sassatelli, 'Virtue, Responsibility and Consumer Choice: Framing Critical Consumerism', in: Brewer and Trentmann (eds), Consuming Cultures, Global Perspectives.

9. Lizabeth Cohen, A Consumers' Republic: The Politics of Mass Consumption in Postwar America. New York: Knopf, 2008.

10. Blurb for Roopali Mukherjee and Sarah Banet-Weiser, Commodity Activism. http://nyupress. org/books/9780814764015/ [accessed on 13 June 2016].

11. Roland Robertson, Globalization: Social Theory and Global Culture. London: Sage, 1992.

12. Ilja van Damme, "From a "Knowledgeable" Salesman Towards a "Recognizable" Product? Questioning Branding Strategies before Industrialization (Antwerp, Seventeenth to Nineteenth Centuries)', in Bert de Munck and Lyna Dries (eds), Concepts of Value in European Material Culture, 1500-1900. Burlington, VT: Ashgate, 2015, 75-101.

13. Jane M. Ferguson, 'Terminally Haunted: Aviation Ghosts, Hybrid Buddhist Practices, and Disaster Aversion Strategies amongst Airport Workers in Myanmar and Thailand', Asia Pacific Journal of Anthropology 15.1 (2014): 47-64.

14. Jane M. Ferguson, 'Terminally Haunted'.

15. Laura Ann Twagira, 'Robot Farmers and the Cosmopolitan Workers: Technological Masculinity and Agricultural Development in the French Soudan (Mali), 1945-68', Special Issue 'Gender, Imperialism and Global Exchanges', Gender \& History, 26 (2014): 459-77.

16. Francesca, Bray, 'Flows and Matrices, Landscapes and Cultures', ICON 22 (2016): 8-19, quotation from p. 13.

17. Bray, 'Flows and Matrices', 13.

18. Barbara Smit, The Heineken Story: The Remarkably Refreshing Tale of the Beer That Conquered the World. London: Profile, 2014; Trentmann, Empire of Things.

19. De tijd: dagblad voor Nederland, 15 May 1953.

20. 'Burgemeester opent expositie Heineken helpt kunst op een blije manier', Het vrije volk: democratisch-socialistisch dagblad, 4 June 1953.

21. De Tijd: Dagblad voor Nederland, 8 August 1953.

22. Australian advertisement, 1952.

23. De Telegraaf, 19 June 1959.

24. Heineken Annual Report, 2016, The Heineken Company, available at http://www.theheinekencompany.com/-/media/Websites/TheHEINEKENCompany/Downloads/PDF/AnnualReport-2016/Heineken-NV-2016-Annual-Report.ashx [accessed 28 June 2017].

25. 'Uit het bedrijfsleven Bevredigende bedrijfsgang bij “Cobra”.' De Tijd: godsdienstig-staatkundig dagblad, 22 March 1954.

26. 'Malaya - Templer Opens Factory 1953', British Pathé, 1953. Film ID: 54.17.

27. de la Bruhezé, 'Manufacturing', 183.

28. de la Bruhezé, 'Manufacturing', 183-209.

29. de la Bruhezé, 'Manufacturing', 194.

30. Morris B. Holbrook, Consumer Research: Introspective Essays on the Study of Consumption.

31. ' $49+$ Unilever Ice Cream Brands from Around the World', 14 December 2015, http://www. advergize.com/marketing/brands/49-top-unilever-ice-cream-brands-from-around-theworld/ [accessed 28 June 2017]. 


\section{2 \\ Re-Mapping Centre and Periphery: Concluding Thoughts}

Ulrich Tiedau

It has been more than two years since that momentous day on which the British electorate narrowly decided to extract itself from (political) Europe, by happenstance coinciding with the long-planned symposium on which the papers that form the basis of this volume's contributions were presented. Naturally, the discussions of historic and current affairs blended into each other and provided ample room for reflection on the relevance of the concepts at the core of this volume for the present.

Ever since, the prospects of the UK crashing out of the European Union by default have increased on a daily basis. Whether one regrets or greets that prospect at this point in time depends on one's political convictions, obviously, and this is not the place to offer a political value judgement. 'Europe and its offshore islands', as the late Ralf Dahrendorf, the former director of the London School of Economics (LSE) and only person who ever was a member of both the German and British parliaments, used to describe this asymmetrical relationship, ${ }^{1}$ have long been likely to come to a different arrangement, if few had foreseen the dramatic, and some would say tragic, way in which the process would play out. In Sir Ralf's modern version of Vincenzo Gioberti's characterization of England as the 'Sicily of Europe' (1851), as referenced by Axel Körner in the introduction to this volume, the UK is pointedly assigned to the periphery of the continent, and its relationship to Europe described as one of subordination. As the old pun about fog over the English Channel ('Continent cut off') suggests, the relationship naturally looks more complex from a British perspective, with several historical (Commonwealth), 
cultural ('Anglosphere') and economic ('global economy') layers overlapping with geographical, or geography-defying, ones.

When I use this example from current affairs, without the benefit of hindsight that usually distinguishes a historian's work from political commentary, it is to show that on the traditional British collective 'mental map', the English Channel seems to lie between the US and the British Isles, whereas the ocean separates the UK from Europe. Mental maps like this, or 'collective mentalities', as Joris van Eijnatten calls them in his contribution to this volume, provide a particularly interesting way to analyse hierarchical and asymmetrical relationships, and they are of course not one-dimensional but multi-layered entities. The illustration chosen for the cover of this volume is thus no coincidence. Unfamiliar representations like inverted charts of the world can be unsettling, and have been used, more often than not with political intentions, to challenge established hierarchies (e.g. between the developed and the developing world; see the controversies about the Peters projection and its variants versus the traditional Mercator projection since the 1970s).

The contributions to this volume are examples of attempts at re-mapping spatial hierarchies from a scholarly perspective, and explore the value of moving beyond the traditional historical model of 'centres' and 'periphery', as introduced by Gunder Frank and Immanuel Wallerstein in the 1970s and 1980s. Using examples of historical mechanisms of cultural and intellectual exchange from both European and global contexts and from different historical periods, they argue for a reconceptualization of the multi-layered relationships between global, regional and sub-regional (political) entities. When questioning existing hierarchies and focusing in particular on perspectives from the allegedly 'lesser' states and cultures, they do so without claiming to fully rewrite European and global history from the perspectives of the peripheries (which would be a desirable undertaking), but in the hope and expectation of providing a historical corrective that rebalances common and frequently unquestioned perceptions.

\section{Note}

1. In his opening address to the 1992 convention of the German Historians' Association (Deutscher Historikertag) in Hannover, for example. 



\section{List of Figures}

Figure 3.1 Mediating between inside and outside.

Source: author.

Figure 4.1 Stacked bar chart of absolute occurrences per year for the term 'Europe(e)s(ch)e kampioenschap(pen)' in newspaper articles in De Telegraaf, Het Vrije Volk, De Waarheid, Leeuwarder Courant, Limburgsch Dagblad and Nieuwsblad van het Noorden (18981990). Made in Python Matplotlib.

Figure 4.2 Stacked bar charts of absolute occurrences per year for 'Europa' in combination with 'atletiek', 'biljart', 'schaatsen' and 'voetbal' in newspaper articles in De Telegraaf, Het Vrije Volk, De Waarheid, Leeuwarder Courant, Limburgsch Dagblad and Nieuwsblad van het Noorden (1898-1990). Made in Python Matplotlib.

Figure 4.3 Nationalities in football: Map of Europe displaying average relative frequency of articles in De Telegraaf (1970-4) mentioning 'Europe' in combination with nationalities. Most historical countries like the USSR and Yugoslavia have been reconstructed (although twenty-first-century boundaries show through). Germany has been taken as a whole; the United Kingdom has been broken down into its constituent parts. Frequencies refer to all (rather than unique) hits per article and they are compared across space within the given period (i.e. synchronically rather than diachronically). Made in Python Basemap and Matplotlib. 
Figure 10.1 Percentage-based occurrences of European and American cities, excluding London, in the PMGZ during the period 1870-1900. Calculated by the author on the full-text archive of $P M G Z$ with frequencies derived from the AntConc tool.

Figure 10.2 Percentage-based occurrences of selected European and American cities, including London, in the PMGZ during the period 1870-1900.

Figure 10.3 Number of documents for the search term 'metropolis' during the period 1700-1800. Source: Burney Collection.

Figure 10.4 Absolute number of documents for the search term 'metropolis' during the period 1800-1900. Source: British Newspaper Archive.

Figure 10.5 Absolute number of documents containing the search terms 'French', 'German', 'Austrian', 'Dutch', 'Belgian', 'European', 'American' metropolis during the period 1800-99. Calculated by the author from data derived from the British Newspaper Archive. 


\title{
Notes on Contributors
}

\begin{abstract}
Alessandro de Arcangelis completed his PhD at UCL with a thesis entitled Hegelians on the Slopes of Vesuvius: A Transnational Study on the Intellectual History of Naples, 1799-1861, which investigated the circulation and reception of German philosophy of history in Risorgimento Italy. His work concentrates on modern European intellectual and conceptual history, with a strong emphasis on transnational history, the history of political thought, philosophy of history and the history of music. He currently teaches modern European history and the history of Western political thought at UCL and world history at King's College London. Correspondence to: alessandro.arcangelis.13@ucl.ac.uk.
\end{abstract}

Joris van Eijnatten is a cultural historian at Utrecht University, the Netherlands. He works on various interrelated fields, including the history of ideas, religion, media and communication. His research is based on source material from the eighteenth century to the present and strongly focused on digital humanities approaches to history. His current research involves popular conceptions in nineteenth- and twentieth-century serial publications such as newspapers. He is an editor of the open-access journal HCM: The International Journal for History, Culture and Modernity. Correspondence to: j.vaneijnatten@uu.nl.

Hermione Giffard is a cultural historian and a historian of technology based in the Netherlands. Her most recent book is Making Jet Engines in World War Two: Britain, Germany and the United States. From 2013 to 2016 she worked on the European project 'Asymmetrical Encounters: Digital Humanities Approaches to Reference Cultures in Europe, 18151992 ' < http://asymenc.eu>, which employed digital methods on largescale digital newspaper repositories and gave rise to the research in this volume. Correspondence to: hgiffard@gmail.com. 
Tessa Hauswedell is a Research Associate at UCL on the international research project 'Oceanic Exchanges: Tracing Global Information Networks in Historical Newspaper Repositories, 1840-1914'. From 2013 to 2016 she worked on the European project 'Asymmetrical Encounters: Digital Humanities Approaches to Reference Cultures in Europe, 1815-1992' < http://asymenc.eu>, which employed digital methods on large-scale digital newspaper repositories and gave rise to the research in this volume. She holds a $\mathrm{PhD}$ in European Cultural Studies from the University of St Andrews and serves as co-convenor of the Digital History Seminar Series at the Institute of Historical Research in London. Correspondence to: t.hauswedell@ucl.ac.uk.

Jan Ifversen is Associate Professor in European Studies at the Department of Global Studies, Aarhus University, Denmark. Prior to his current appointment, he was Associate Professor in European Studies at the Centre for European Cultural Studies at Aarhus University until 2004. From 2004 to 2011, he was head of the Department of History and Area Studies, and from 2011 to 2015 Vice-Dean for Knowledge Exchange at the Faculty of Arts at Aarhus University. He is the author of two books in Danish: a history of current European history (Hjem til Europa, 1992) and a book on power, democracy and discourse (Om magt, demokrati og diskurs, two volumes, 1997). He has published many articles on conceptual history, European history, European identity politics and history politics. He is one of the founding members of the international research group on conceptual history, the History of Concepts Group. Correspondence to: jif@cas.au.dk.

Axel Körner is Professor of Modern History and Director of the UCL Centre for Transnational History, where he coordinates the projects 'Passionate Politics' and 'Reimagining italianità: Opera and Musical Culture in Transnational Perspective'. His most recent book, America in Italy: The United States in the Political Thought and Imagination of the Risorgimento, 1763-1865, won the Helen \& Howard Marraro Prize of the American Historical Association. Supported by a Major Research Award from the Leverhulme Trust, he currently works on a transnational history of the Habsburg monarchy between 1804 and 1918. He has held visiting positions at the Institute of Advanced Study in Princeton, the Remarque Institute of New York University, and at the École Normale Supérieure in Paris. Correspondence to: a.korner@ucl.ac.uk. 
Nicola Miller is Professor of Latin American History at UCL. She is interested in the intellectual, cultural, political and international history of the Americas, in comparative and transnational perspectives. She has worked particularly on nationalism and national identity, modernity and modernism, and the social role of intellectuals. Her current research on the history of knowledge in Latin America will be published in the monograph Republics of Knowledge by Princeton University Press, forthcoming in 2019. Correspondence to: nicola.miller@ucl.ac.uk.

Michael North is Professor and Chair of Modern History at the University of Greifswald, Germany, Honorary Doctor of the University of Tartu and Director of the International Graduate Programme 'Baltic Borderlands'. From 2007 to 2010 he acted as Deputy Vice Chancellor of Research and Internationalization of Greifswald University. His publications include: Art and Commerce in the Dutch Golden Age (Yale University Press, 1997), Art Markets in Europe, 1400-1800 (Ashgate Publishing, 1998, co-authored with David Ormrod), Material Delight and the Joy of Living: Cultural Consumption in Germany in the Age of Enlightenment (Ashgate Publishing, 2008), Artistic and Cultural Exchanges between Europe and Asia 14001900 (Ashgate Publishing, 2010), The Expansion of Europe, 1250-1500 (Manchester University Press, 2012), Mediating Netherlandish Art and Material Culture in Asia (Amsterdam University Press, 2014, co-authored with Thomas DaCosta Kaufmann) and The Baltic: A History (Harvard University Press, 2015). Correspondence to: north@uni-greifswald.de.

Marta Petrusewicz, a native of Warsaw, is Professor of Modern History at the Università della Calabria, Italy, and Professor Emerita of Modern History at City University New York. Her books include Latifundium: Moral Economy and Material Life in a Nineteenth-Century Periphery; Un sogno irlandese: la storia di Constance Markiewicz comandante dell'IRA; and Come il Meridione divenne Questione: rappresentazioni del Sud prima e dopo il 1848. She is the editor, with Jane Schneider and Peter Schneider, of Sud: conoscere, capire, cambiare; with Giovanna de Sensi, of Unità multiple: Centocinquant'anni? Unità? Italia?; and, with Leandra D'Antone, of La storia, le trasformazioni: Piero Bevilacqua e la critica del presente. She is currently writing a comparative history of the European peripheries in the nineteenth century. Correspondence to: marta.petrusewicz@unical.it.

Jens Späth is Lecturer in Modern European History at Saarland University, Germany. He has published widely on the political, constitutional 
and cultural histories of Italy, Spain, France and Germany in a comparative and transnational perspective in the nineteenth and twentieth centuries. His publications on nineteenth-century Mediterranean history include Revolution in Europa 1820-1823: Verfassung und Verfassungskultur in den Königreichen Spanien, beider Sizilien und Sardinien-Piemont (2012); 150 Jahre Risorgimento - geeintes Italien? (2014); and 'Strumento, simbolo, mito: la Costituzione di Cadice (1812) ed il liberalismo transnazionale europeo', in Rassegna Storica del Risorgimento, 99 (2014). Correspondence to: jens.spaeth@uni-saarland.de.

Harry Stopes is a historian of nineteenth- and twentieth-century Europe, who completed his PhD at UCL in 2017. He is interested in social and cultural history, especially in their global and transnational dimensions. His doctoral thesis concerned elites in the cities of Lille and Manchester, with a focus on how they imagined the place of the city in the wider world, and how these ideas were expressed through cultural policy and responses to the connectivity engendered by economic globalization. He is currently a Marie Skłodowska-Curie postdoctoral fellow at the Free University of Berlin. Correspondence to: harry.stopes@gmail.com.

Ulrich Tiedau is an Associate Professor in the Department of Dutch at UCL and an Associate Director of the UCL Centre for Digital Humanities. He serves as editor-in-chief of Dutch Crossing: Journal of Low Countries Studies and co-convenor of the Low Countries History research seminar series at the Institute of Historical Research, London. Correspondence to: u.tiedau@ucl.ac.uk. 


\section{Index}

Figures are denoted by italics.

\author{
absolutism 115, 119-20, 128 \\ advertising 10, 180-6 \\ Africa 5, 39 \\ agrarian elites 121, 123 \\ agriculture \\ Baltic provinces 72 \\ boom in 21, 121 \\ cattle ranches 77-8 \\ depression 25, 119-20 \\ French Sudan 180 \\ Italian 138 \\ modernization 19-21 \\ airports 179-80 \\ Alaska 66, 69, 70 \\ Aleut people 68-9 \\ Alfred, Mary 36-7 \\ Amin, Samir 4 \\ Anderson, Benedict 48, 79 \\ Annales school of historians 47 \\ AntConc (digital tool) 157, 160-1 \\ Antiquissima Italorum Sapientia (Vico) 149 \\ Antwerp 179 \\ Arcangelis, Alessandro de 9 \\ Argentina 8, 56, 77-8 \\ Armitage, David 2 \\ Arrighi, Giovanni 19-20 \\ art gallery, and the city 100-3 \\ Art Gallery Committee, Manchester 100-1 \\ Aschehoug, Torkel Halvorsen 24 \\ Assembly of Engineers, Argentina (1886) 89 \\ asymmetrical counterconcepts 34-5 \\ Athletics (1880-1990) 54 \\ Australia 182-3 \\ Austria 116 \\ authoritarianism 37 \\ autodidacticism 80, 84 \\ autonomy 33, 170 \\ Azov, Russia 65
}

Balbo, Cesare 122, 124, 140

Baltic Germans 71

Baltic provinces 70-3

Baltic Sea 8, 64

Banti, Alberto 141, 142

barbarians 35,36

bargaining power 31,33

Bastiat, Frédéric 24

Bateman, John F. 88

Bayly, Christopher A. 3, 5
Bayonne, Statute of 114

Bee, Samantha 44

Belgian Constitution (1831) 127

Benjamin, Walter 9

Benso, Camillo, Count of Cavour 140

Bering, Vitus 66

Berlin 163, 168, 169

Bertrand, Eugène 97-8

'big data' 51

Bill of Rights, US 142

Billiards (1880-1990) 54

Black Sea 64

Bloch, Marc 47

Blum, Jerome 20

book censorship 148

Bourbon dynasty 113-14, 116-17, 127, 138, 148

Bourbon Reforms (Spanish Crown) 82

bourgeoisie 19, 21

Braganza dynasty 113, 118

Brazil 79, 118, 121

Brexit 40, 188

Britain

dependent territories 19

engineers from 88

global relationships 9

and North Pacific 66

perception of $1-2$

press in 9

referendum (2016) 1-2

ships from 66, 69

uprisings in 119

British Empire 156-7

British Newspaper Archive (BNA) 157, 164-5, 165, 168

Bruhezé, A. A. A. de la 177

Bruno, Giordano 150

Buenos Aires 87-90

buffer zones 35

Burney Collection Newspapers 157, 162, 162

Butterworth, Walter 102

Cádiz, Constitution of 114-15

Calabria 19-20

Calhoun, Craig 33

Calvé (Unilever subsidiary) 184

Campanella, Tommaso 150

capitalism 19-20, 21, 96

'Capitalist Development in Hostile Environments' (Arrighi) 19-20

Casavalle, Carlos 78 
Castañeda, Father Francisco 80

Catherine I of Russia 70

Catherine II, the Great 65, 70

Catholic Emancipation Act (1829) 22

Catholicism 22, 121

Cattaneo, Carlo 139

causation 150

Central Europe 34, 35, 39

centrality 24, 29-30, 31, 33

Chabod, Federico 135

Chamisso, Adelbert von 67-8

Charte constitutionnelle (French constitution) $115,122,127$

Chaudhuri, Kirti 5

China 5, 64-6, 68, 69, 83-4

Choris, Louis 67-8

'circularity', of European thought 148-52

cities, classical 171

cities, European 9, 155, 160-1, 160-1,

$$
\text { 167-72, } 168
$$

cities, provincial 94-104

civilization 18, 23, 35, 39

Clark, Peter 155

class systems 19

Cobbett, William 158

Cold War 39

collectivity of knowledge 78, 80-1

collocation analysis 157, 162, 166, 167

colonialism 8, 39, 91, 117-18, 120

Common Market, European 39

computers, historical research and 50-1

consciousness, public 48

constitutional history 111-29

consumer activism 179

consumption

and advertising 180-6

habits 167

and transnationality 176-86

core-periphery paradigm 4, 17-18

Cortés, Francisco Javier 83

Cortes (Spanish parliament) 114

Coudenhove-Kalergi, Richard von 39

crisis scenario 40

critical development theorists 6

Croce, Benedetto 127, 135-6

crops 20-1, 72

cultural debate, Italian 135-53

cultural studies 45

Cuoco, Vincenzo 142-4

Cusco school of art, Peru 83

Czechoslovakia, dissolution of 34

Dahrendorf, Sir Ralf 188

Damme, Ilja van 179

Dante Alighieri 135

d'Artois, Charles-Ferdinand, Duc de Berry 119

Davis, John 127

D'Azeglio, Massimo 137

De Monarchia (Dante) 135

De Telegraaf (newspaper) 53, 57, 58

Del primato morale ... (Gioberti) 144

Delle origini italiche ... (Mazzoldi) 144

Delle speranze d'Italia (Balbo) 140

Derrida, Jacques 27

Descartes, René 146, 150

development theorists 6, 17 digital humanities 7, 157

digital view, of Europe 50-8, 160-1

diplomacy 124

diversity, in Europe 27-8, 30, 46, 51-2

Divina Commedia (Dante) 135

drawing, art of 81-2, 83

Driver, Felix 156, 169

Early English Books Online (EEBO) 157, 162

Eastern Europe 34, 35, 39

Eckert, Andreas 5

Eco, Umberto 2

economic indicators 29

economic theories 4

education 22, 36, 82, 85, 90

Eijnatten, Joris van 7

Eisenstadt, Shmuel 112

El-Tayeb, Fatima 36

empty signifiers 37

energy production, European 137-8

engineering 87-90

England

Gioberti's description of 1,188

'Manchester civilization' 23

as a metropolis $170,171,172$

Enlightenment, The 39, 72, 82, 113

Estonia 70, 71, 72, 73

Estrada, Álvaro Flórez 120

ethnic composition, Riga 72-3

ethnic minorities 33, 40

EU (European Union)

enlargement of 35

foundation 39

member states 1-2, 33

motto 27,52

policies 30, 35, 41

euro-crisis 39-40

Europe

art galleries in 101

art study in 85

Britain's position in 1

as a civilization 39

class systems 19

descriptions of 27

digital view of $50-8,160-1$

notion of 38

politics in 28-9

rise of 5

European Championships (1880-1990) 53

European constitutions 22

European Union (EU)

enlargement of 35

foundation 39

member states 1-2, 33

motto 27, 52

policies 30, 35, 41

Eurovision Song Contest 52

exile 22, 120, 144

exiles, liberal 112, 125, 128

expansionism 39

expeditions, scientific 81,83

exploration, trade and shipping 63-74

export production $21,72,83,85,122$

Faehlmann, Friedrich Robert 71

Far East 65-9 
Febvre, Lucien 27, 47

federalism 33, 145

Ferdinand I 117, 122, 148

Ferdinand VII 114, 117, 120, 122

Ferrari, Giuseppe 140

feudalism 4, 121

Fierro, Pancho (Francisco) 82-4

Filippi, Luigi 124

Finland 65

floating signifiers 37

Football (1880-1990) 55

football competitions 53, 56

football, nationalities in 57,58

Foscolo, Ugo 144

France

Cuoco on 142-3, 143

Enlightenment in 113

Gioberti on 147

and Italy 148

leading power 140

literacy in 137

opera and 97-100

and Spain 114

Franchetti, Leopoldo 138

Frank, André Gunder 4, 17

French Revolution 120, 127, 142

French Sudan 180

Fuentes, Carlos 84

fur trade $64,66,68,69,70,73$

Gadamer, Hans-Georg 45

Geertz, Clifford 48

Gerhard, Anselm 2

Germany

avoiding revolution 119

Cuoco on 142-3

and football 57,58

Gioberti on 147

idealism 148

and Italy 150-1

literacy in 137

philosophy in 150-1

ghettos, urban 30

Giffard, Hermione 10

Gilbert, David 156, 167, 169

Gioberti, Vincenzo 1-2, 144-6, 151, 152

Gladstone, William 170

global, and local relationships 10

global inequalities 4

Global Interdependencies:... (Iriye) 155

globalization 3, 8, 96-7, 180-6, 186

'Globalizing peripheries' 7-8

Goody, Jack 91

Google Ngram Viewer 28

grain trade 65,72

Gramsci, Antonio 136

Grand Opéra (art form) 98

Great Britain see Britain

Great Exhibition (1851) 178

Greater Britain Exhibition (1899) 170

Greece 40-1, 143

Guizot, François 27

Habsburg dynasty 116

harmoni liberalismen theory 24

harmonic school 24, 25 'harmony', use of 23

Hauswedell, Tessa 9

Hawkshaw, Sir John 88

Hawkshaw, Son \& Hayter (civil engineers) 88,89

Hegel, George Frederich 147, 148-9, 151

Heineken 177, 180, 181-3, 185

Heineken, Alfred Henry 'Freddy' 181

Herder, Johann Gottfried 19

Hernández, José 8, 77-8, 84

Herriot, Édouard 102

hierarchies, national 8

hierarchies, spatial 2-3, 8, 9, 10

Hindle Wakes (Houghton) 94-5

Hoganson, Kristin 178

Houghton, Stanley 94-5

Huergo, Luis 87, 88, 89-90

Humboldt, Alexander von 82

Hungary 41

ideal, European 135-6, 148

identities

American 49-50

European 36, 37, 49-50, 56-7, 121, 139-47

local 95, 102-3, 121

theorizing $45-7$

identity

civic 97

markers 38

national 96, 97, 121, 126

politics 33-4, 37-40, 41, 46

Ifversen, Jan 7

Imagined Communities (Anderson) 48

'imagined community' 48-9

immigration $35,36,72$

'imperial city' idea 156-72

imperialism 18

incomes, European 137

independence 40, 81

India 3

Indian Ocean 5

indigenous people 32, 68-9, 170

individualism 22

industrialization

Britain 158

European 17, 22, 95, 96, 138

Russian Empire 72

Smith and 20

infrastructure, European 137, 165

institutions, city 164

Instructions for the Rancher: ... (Hernández) 77-8

Ireland 18-19, 22, 170, 171

Iriye, Akira 155

Italy

art study in 85

comparison with Britain 137

and diplomacy 125

economy of 4

and Europe 137-41

football and 56-7

and France 116, 148

and Germany 150-1

Gioberti on 1-2

influence 117

and intellectual modernity 135-53 
music in 2

nation state 121

national primacy and transnationalism

$$
\text { 141-7 }
$$

North-South divide 138

political thinkers in 9

and Spanish Constitution 123, 124-5, 127

wage labour in 19-20

Japan 3, 66-7, 74, 182

Jewish population, Riga 73

John VI of Portugal 122

Journey Around the World (Langdorff) 66

Kant, Immanuel 150-2

Keene, Derek 158

Kempes, Mario 56

knowledge 8, 78-81, 85-6, 91

Kodiak people 68-9

Koselleck, Reinhart 34-5, 37

Kotzebue, Otto von 66, 67, 69, 119

Krusenstern, Adam Johann von 66, 67

Kuchuk-Kainardji, Treaty of 65

Kundera, Milan 34, 41

La filosofia italiana... (Spaventa) 149-51

La giovinezza (Sanctis) 146-7

labour 19-21

land-based modernization 17-26

landowners 20, 22

Langdorff, G. H. von 66

Latifundium (Petrusewicz) 4

Latin America 8, 77-91, 117-18, 121, 122

Latvia 70, 71, 72-3

learning, value of 84

Lees, Andrew 164, 166

Legrand, Géry 98

Lenin, Vladimir 4

liberalism 17, 21-3, 120, 124-9

Lille 8, 97-9

liminality 36, 39, 41

Lisianski, Yuri F. 66

L'Italia avanti il dominio de'romani (Micali) 144

L'Italia (ship) 88

literacy 19, 120, 137

literary purism 147

Livonia 64, 71, 72, 73

localization 10, 25, 99

localized transnationalism 78-9, 81, 83

$\log 0$ 183, 185

London

British public debates and 155-72

consumption habits 167

entertainment 166

literature about 158

management and administration 164-5

money and commerce 166

poverty 159, 166

prime metropolis 9, 157-61

London Daily News 170

London of the Future (London Society) 158, 163

London Programme, The (Webb) 159

London Standard 171

Lydéric (Ratez) 98-100

Lyon 102
Madero, Eduardo 87, 88-9

Mahler, Gustav 3

Majluf, Natalia 83-4

Malharro, Martín 85-6

Mamiani, Terenzio 140-1

Manchester 8, 94-5, 100-3

'Manchester civilization' 18, 23

Manchester School 6, 18, 24

marginality, within Europe 7, 9, 27-41

marginalization, process of 29-30

margins 29-30, 40-1

maritime networks 3, 137

marketing, targeted 180-6

Marx, Karl 4

Mazzini, Giuseppe 139-40, 144-5

Mazzoldi, Angelo 144

mediating, between inside and outside 32

Mediterranean 8, 9, 35, 111-29

mentalities, collective 47-50, 49, 188-9

Merino, Ignacio 84

'metropolis'

the imperial 168-72

London as prime 9-10, 157-61

meanings of 157, 161-8

Metropolitan Board of Works 164, 166

metropolitanism 163

Metternich, Klemens von 111, 119, 120

Micali, Giuseppe 144

middle classes 71, 95, 123

Middle East 31

migration $32,36,70$

military secret societies $120,122,125$

Miller, Nicola 8

minorities, ethnic 33, 40

Miss Europe pageant 52

modernity 96, 99-100, 103, 112, 135-53

modernization 4, 17-26, 19-21, 111-12, 120-1

monarchies 22, 113, 116, 118, 122, 146

Morozov, Viatcheslav 36, 37

Mozart, Amadeus 3

multiculturalism 37, 46

multinational companies 10, 176-86

Munich 102

Murat, Marshal Joachim 113, 114

music, European 2-3, 97-100, 166

Mutis, José Celestino 83

Nadezhda (Russian ship) 66-7

Naples 113

Napoleon Bonaparte 113, 118

'nation', definitions of a 79, 141-2

nation states $29,47,96,121$

national

hierarchies 8

identity 96, 97, 121, 126

knowledge 85-6

minorities 33

nationalism 144-7

art histories 84

emergence of 48

ethnic 70-3

ideology 39, 95-6

resurgence of 46

nationalities, in football 57, 58

'natural order' 23, 24

Neapolitan liberals 124, 125 
Nerchinsk, Treaty of 69-70

Netherlands 51-7, 66, 177, 180-6

Neva (Russian ship) 66

New York 160-1, 160-1

newspapers

advertisements in 183

American cities in 160-1, 160-1, 168

Argentinian 87, 89

British 157, 164-5, 165, 168, 170-1

and competitive Europe 51-4, 53-5, 56

Estonian 71

Italian 148

local 104

London 158, 159-61

'metropolis' mentions in 162, 162

Parisian 160, 160

revolutions and 123-4

rise of 48-9

nodal points, stabilization of $37-9,40$

North, Michael 3, 8

Norway 18-19, 22, 24

Nouveaux principes d'économie politique ...

(Sismondi) 25

Nuovo saggio sull'origine delle idee (Rosmini) 146

Nystad, Treaty of 65

Occident, the 45

Odessa 65

Onís, Luis de 125

opera, role of 3, 97-100

Orbán, Viktor 41

orientalism 39, 45, 111

Osterhammel, Jürgen 86, 104, 155, 156, 165

Other, Self and the 45-7, 49, 56, 59

Ottoman Empire 64, 119

Pacific Ocean 8, 66, 68

Pall Mall Gazette (PMGZ) 159-61, 164, 166, $168-9,171$

Palma, Ricardo 82

Palmieri, Luigi 147

pan-European culture 39

papacy, the 121, 145

Paris

art study in 85

Benjamin on 9

and Berlin 169

as a metropolis 163,167

in newspapers 160,160

opera in $97-8$

Treaty of 116

Parker, Noel 29, 31

'patrioterismo', in art 86

Paul I of Russia 71

peasants 19

Pepe, Guglielmo 125

Peru 82

Peruvian Traditions (1872-1910) (Palma) 82

Peter the Great 64

Petrusewicz, Marta 4, 6-7, 127

philosophy

European 135-53

Italian 147, 149-51

photography 81

Piedmontese liberals 124

Pietro Leopoldo, Grand Duke of Tuscany 113
Plato in Italy (Cuoco) 143

pluralism 30

Poland 18-19, 22

Polanyi, Karl 22

political-economy references 23

Pollard, Sidney 20

populations 65,72

Portugal

Enlightenment in 113

and France 117

imperial state 116

loss of colonies 119, 120, 122

nation state 121

and Spanish Constitution 112, 123, 126-7

positive marginality $30-4$

post-Napoleonic revolutionary wave 119-23

postcolonialism 3, 5

poverty $159,166,169,171$

power structures 50

Prague 2-3

Predpriatie (Russian ship) 69

primacy, notion of 143-4, 145

Primato (Gioberti) 146, 147

pronunciamiento (miitary coup) 120, 121

provincial cities, in global order 94-104

questione meridionale studies (Franchetti and Sonnino) 138

racism $7,44,50$

railway networks $72,137,165$

Ratez, Émile 98-9

reference culture 6-7, 50, 79

referendums $1-2,40,188$

Reformation, the 145-6

refugee crisis, European 31, 35, 36, 40, 41

regions, and margins $31-2$

religion

Catholicism 22, 121

causation and 150

Christianity 39, 145-6

Islam 5, 37

Renaissance, the 150

republics of knowledge 8

'Restoration' in southern Europe 116-19

revolutions 8-9, 73, 111-29, 142

Rezanov, Count Nikolai 66, 67

Ricardo, David 24

Riga 72

Risorgimento, Italian 135-6, 141, 146

rivalry, European 51-2

Robertson, Roland 179

Roca, President Julio Argentino 88, 89, 90

Rodger, Richard 162, 164

Roma people 40

Romagnosi, Gian Domenico 138-9

Roman Empire 35, 36

Rome 85

Rosmini, Antonio 146, 152

Rotenberg, Robert 162-3

Royal Manchester Institution 101

Rumelili, Bahar 36, 37

Rumyantsev, Count Nikolay 67

Rupnik, Jacques 27

rural areas 32, 73, 158

Rural Rides (Cobbett) 158 
Rurik (Russian ship) 67-8

Russia 8, 36, 37

Russian-American Company 67, 68-9

Russian Empire

Baltic provinces $70-3$

expansion 64-5

and Far East 65-9

first circumnavigation 66-7

Pacific presence 65-70

trade, shipping and exploration 63-74

Russian Navy 74

Said, Edward 45

Saint Andrew's Cross 57, 58

St Petersburg 64-5, 168

San Martín, José de 81

Sanctis, Francesco De 146

Sardinia 112, 119, 120, 121, 124, 127

Sarmiento, President Domingo 88

Saunier, Pierre Yves 156

Say, Jean Baptiste 24

Scandia, Southern Sweden 31

Schneer, Jonathan 159

Schools of Drawing 80-1

Schweigaard, Anton Martin 24

Scienza delle costituzioni (Romagnosi) 138

Scotland 33, 170

Scottish Nationalist Party (SNP) 40

secret societies 120, 122, 125

Self, and the Other 45-7, 49, 56, 59

Sepolcri (Foscolo) 144

shipping, trade and exploration 63-74

Siberia 64

Sicily 115, 117

signifiers 37

Sismondi, Jean-Charles-Léonard Simonde de 24-5

Skating 55

slavery 7,117

Slovakia 34

Smith, Adam 19, 20, 23-4

Sonnino, Sydney 138

Southern Europe

economy of 122

euro-crisis 39-40

liberal constitutional revolutons 111-12, 127-8

philosophical modernity 148, 153

refugee crisis 35

'Restoration' in 116-19

sovereignty 79,123

Spain

and Europe 116-17

loss of colonies 120, 122

nation state 121

and revolutions 119

and Spanish Constitution 125

Spanish Constitution (1812) 8-9, 112, 113-15, 122, 126-9

Späth, Jens 8

spatial hierarchies 2-4, 8, 9, 10

Spaventa, Bertrando 148-52

Spinoza, Baruch 150

Spirit, idea of 150-1

sports competitions 52-8, 53-5, 59

stabilizations, discursive $37-8$
Stead, William 159-60

Stopes, Harry 8, 10

Storia dell'idea di Europa (Chabod) 135

Storia d'Europa nel secolo decimonono (Croce) 135-6

Subrahmanyam, Sanjay 2

Suvarnabhumi Airport, Bangkok 179-80

Sweden 64,65

tactics, margins and 31-3, 40

tariffs, trade 138

territoriality 29,33

theatrical decentralization 98

thick description 48

trade 138,178

trade, shipping and exploration 63-74

Transformation of the World, The

(Osterhammel) 155

transnational liberalism 128-9

transnationalism

and consumption 176-86

and Italian national primacy $141-7$

localized 78-9, 81, 83

processes 85

provincial 94-104

transport networks 3, 72, 137, 165, 179-80

treaties 65, 69, 116

Trentmann, Frank 178

Tsipras, Alexis 40-1

Tsushima, Battle of (1905) 74

Turkey 31-2, 36, 37, 39, 65

Turner, Frederick Jackson 47

Turner, Victor 35-6

Two Sicilies, Kingdom of the (1815-60)

book censorship 148

Constitution of the 127

independence 19

industry in 138

reforms 118

return to Latin 148

revolution 119

and Risorgimento 121

and Spanish Constitution 112, 124, 125, 126

Ukraine 41, 70

UN (United Nations) 32

unification, Italian 135-6, 138-9, 141-5

Unilever 177, 180, 184-5, 185

United Nations (UN) 32

United States

Bill of Rights 142

cities mentioned in newspapers 159-61, 160-1, 168

constitution 2

and Europe 44, 45, 47

identity 49-50

position in world 2

public debate on Europe 7

racism in 44

and Russia 66, 67-70

slavery 7

views of 47

'United States of Europe' notion 139

universities 22, 36, 90

urbanization 32, 158, 164 
Vachot, Jules-Henry 97

Vallejo, César 91

Vick, Brian 116

Vico, Giambattista 19, 25, 145, 149, 150-1

Victor Emanuel I 122

Vienna 9, 163, 168-9

Vienna, Congress of (1814-15) 22, 111, 113, 116

violence, use of 5

Vladivostok 70

vocazioni territoriali 25

voting rights 137

wage labour 19-20, 21

Wagner, Richard 97, 99
Wales 170

Wallerstein, Immanuel 4

Walters, William 35

Wealth of Nations, The (Smith) 23-4

Webb, Sydney 159

Weber, Carl Maria von 3

Western Daily Press 170

Western Europe 34, 155

Wolff, Larry 39

World's fairs 178

Zamoyski, Count Andrzej 22

Zulus, the 170 
Historians often assume a one-directional transmission of knowledge and ideas, leading to the establishment of spatial hierarchies defined as centres and peripheries. In recent decades, transnational and global history have contributed to a more inclusive understanding of intellectual and cultural exchanges that profoundly challenged the ways in which we draw our mental maps.

Covering the early modern and modern periods, Re-Mapping Centre and Periphery investigates the asymmetrical and multi-directional structure of such encounters within Europe as well as in a global context. Exploring subjects from the shores of the Russian Empire to nation-making in Latin America, the international team of contributors demonstrates how, as products of human agency, centre and periphery are conditioned by mutual dependencies; rather than representing absolute categories of analysis, they are subjective constructions determined by a constantly changing discursive context.

Through its analysis, the volume develops and implements a conceptual framework for remapping centres and peripheries, based on conceptual history and discourse history. As such, it will appeal to a wide variety of historians, including transnational, cultural and intellectual, and historians of early modern and modern periods.

Tessa Hauswedell is Research Associate and Teaching Fellow at the UCL School of European Languages, Culture and Society and the UCL Department of Information Studies. She also is a co-convenor of the IHR Digital History Seminar Series.

Axel Körner is Professor of Modern History and Director of the UCL Centre for Transnational History, where he coordinates the projects 'Passionate Politics' and 'Reimagining italianità: Opera and Musical Culture in Transnational Perspective'.

Ulrich Tiedau is Associate Professor in the UCL Department of Dutch and an Associate Director of the UCL Centre for Digital Humanities. He is also serving as editor-in-chief of Dutch Crossing: Journal of Low Countries Studies. 